\title{
31. ALBIAN TO PLEISTOCENE CALCAREOUS NANNOFOSSILS FROM THE WESTERN SOUTH ATLANTIC, DSDP LEG 39
}

\author{
Katharina Perch-Nielsen, Department of Geology, Swiss Federal Institute of Technology, Zürich, Switzerland
}

\begin{abstract}
Calcareous nannofossils were obtained from all sites drilled on Leg 39 (Figure 1). Late Albian and Turonian through Pleistocene assemblages were studied. Preservation varies considerably, usually deteriorating down the hole except for the Paleocene, where preservation is often better than in the overlying Eocene. Generally, Martini's (1971) zonation, and to a lesser extent Bukry's (1973c), were used as a scale for the Tertiary; a partly emended zonation is proposed for the Cretaceous part of the sequence (Tables 1 and 2). Discoaster/Chiasmolithus ratios were estimated in the Oligocene and Eocene samples, and suggest relatively warm conditions, except for the Oligocene at Site 357 and the middle Eocene at Sites 354, 356,357 , and 358 . Braarudosphaeraceae are absent or very rare in the Neogene at Sites 353, 354, 356, and 358, rare in the Oligocene and upper Eocene at Site 357 and the Miocene at Site 355 (turbidite ?), and few in the middle Eocene at Site 357 and the upper Eocene at Site 359. No Braarudosphaera chalk was recovered, but Braarudosphaera is common in some lower Paleocene samples at Site 356 and absent or rare in the Cretaceous samples.

Special attention was given to the succession of first occurrences of species of Cruciplacolithus, Chiasmolithus, Ericsonia, Hornibrookina, Fasciculithus, Heliolithus, discoasters, and Prinsiaceae in the Paleocene at Site 356. Markalius is suggested to be the ancestor of fasciculiths and discoasters, and Hornibrookina to have evolved from Biscutum. The following new species are described: Amaurolithus ninae, Ceratolithus atlanticus, Chiasmolithus frequens, Cruciplacolithus notus, C. primus, Markalius variabilis, Neochiastozygus cearae, Triquetrorhabdulus challengeri, Ellipsolithus bollii, and Hornibrookina edwardsii.
\end{abstract}

\section{INTRODUCTION}

The calcareous nannofossils were mainly studied for biostratigraphic age determination. The Cenozoic zones represented and their correlation to a numerical timescale are given in Table 3. Tables 4 through 22 contain the species distribution in the samples studied by light microscope. In these tables, the genera are assigned to families according to Perch-Nielsen (1971a) for the Tertiary, and the species are listed alphabetically for the Cretaceous. Some paleoecological observations were made on the basis of species distribution, and are included in the site chapters.

Selected samples were studied by SEM to illustrate the coccoliths and nannoliths, and special attention was given here to the stratigraphically important Tertiary genera Ceratolithus, Sphenolithus, Helicopontosphaera, Chiasmolithus, Discoaster, and Neochiastozygus as well as to some poorly known genera (see also PerchNielsen and Franz, this volume).

\section{CALCAREOUS NANNOFOSSIL ZONES}

\section{Cretaceous}

The zonation used in the Cretaceous includes zones used by Martini (1969, 1976), Cepek and Hay (1969), Thierstein (1975), Perch-Nielsen (1972), Roth (1973), and Bukry and Bramlette (1970). Martini (1976) discussed the correlation of most zones with the Upper Cretaceous stages. The definition of the zones, as used here, and their distribution at Leg 39 sites is shown in Table 1 and is discussed below from bottom to top.

Eiffellithus turriseiffeli Zone, Thierstein, 1971, emend. Roth, 1973

Definition: Interval from the first occurrence of $E$. turriseiffeli to the first occurrence of Lithraphidites alatus.

Stratigraphic position: Upper Albian.

Remarks: This zone was found only at Site 356, where its base was not reached. Preservation was very 


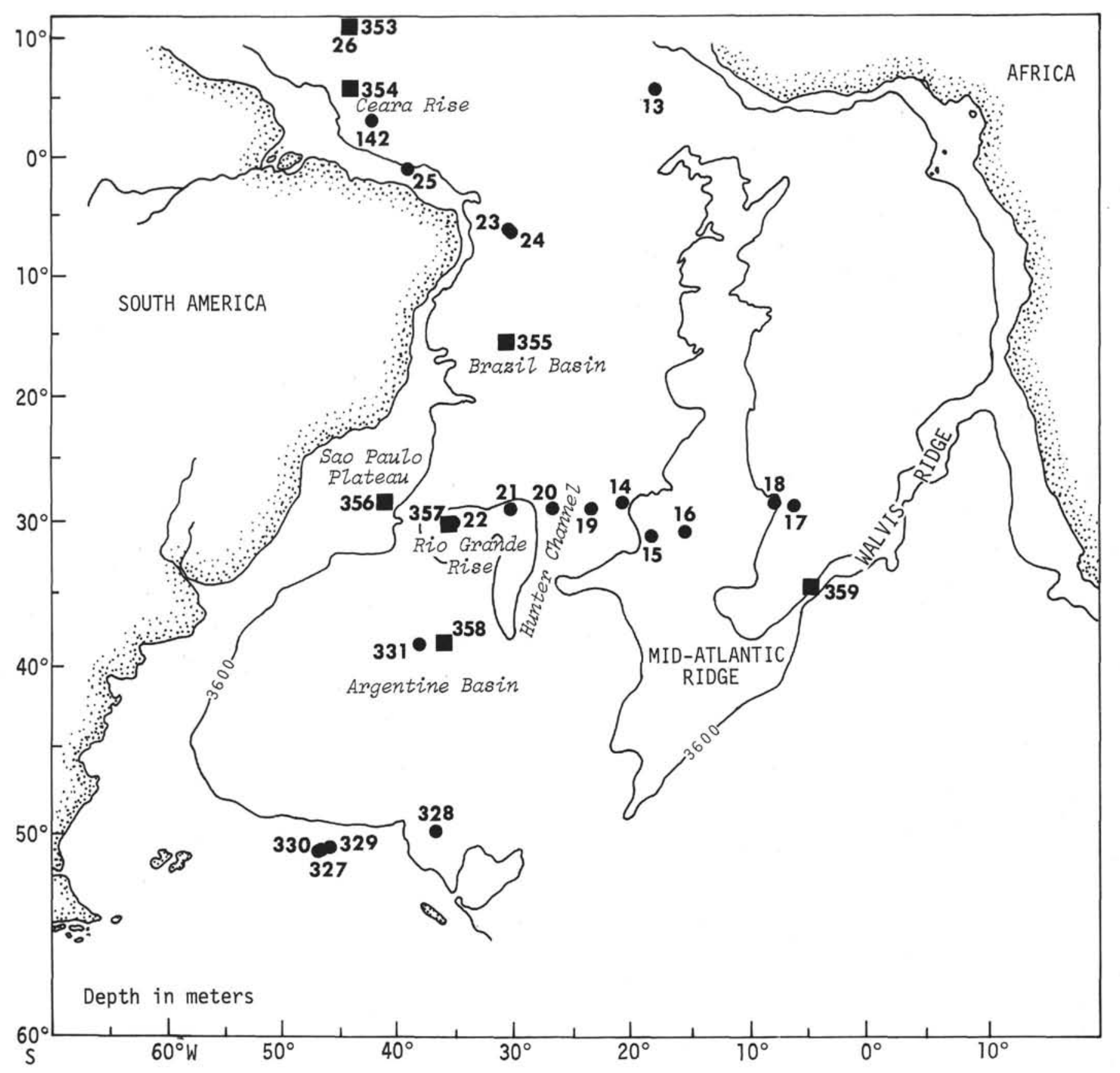

Figure 1. DSDP Leg 39 site locations, DSDP Leg 3, 14, and 36 site locations.

poor, and the only common coccolith in the assemblage of this zone is W. barnesae. E. turriseiffeli reaches few and Nannoconus sp. is also consistently present in low numbers, throughout the zone. The top of the zone is not present, since the Cenomanian and lower Turonian are missing at this site, as indicated by planktonic foraminifers. Thus, it is not known whether L. alatus is present in this part of the South Atlantic Ocean.

\section{Micula staurophora Zone, Roth 1973}

Definition: Interval from the first occurrence of $M$. staurophora to the first occurrence of Marthasterites furcatus.
Stratigraphic position: Mid/upper Turonian.

Remarks: This zone was found only at Site 356, where its base is not present. $W$. barnesae and $M$. staurophora are the only coccoliths that are consistently present in large quantities in the poorly preserved assemblages. $M$. staurophora, however, also becomes rare toward the bottom of the interval. No Nannoconus were found in this or any younger zone at Site 356. Gartnerago obliquum occurs only sporadically.

Marthasterites furcatus Zone, Cepek and Hay, 1969 emend. this paper

Definition: Interval from the first occurrence of $M$. furcatus to the first occurrence of Broinsonia parca. 
TABLE 1

Calcareous Nannofossil Zonation of the Cretaceous of Leg 39 Sites

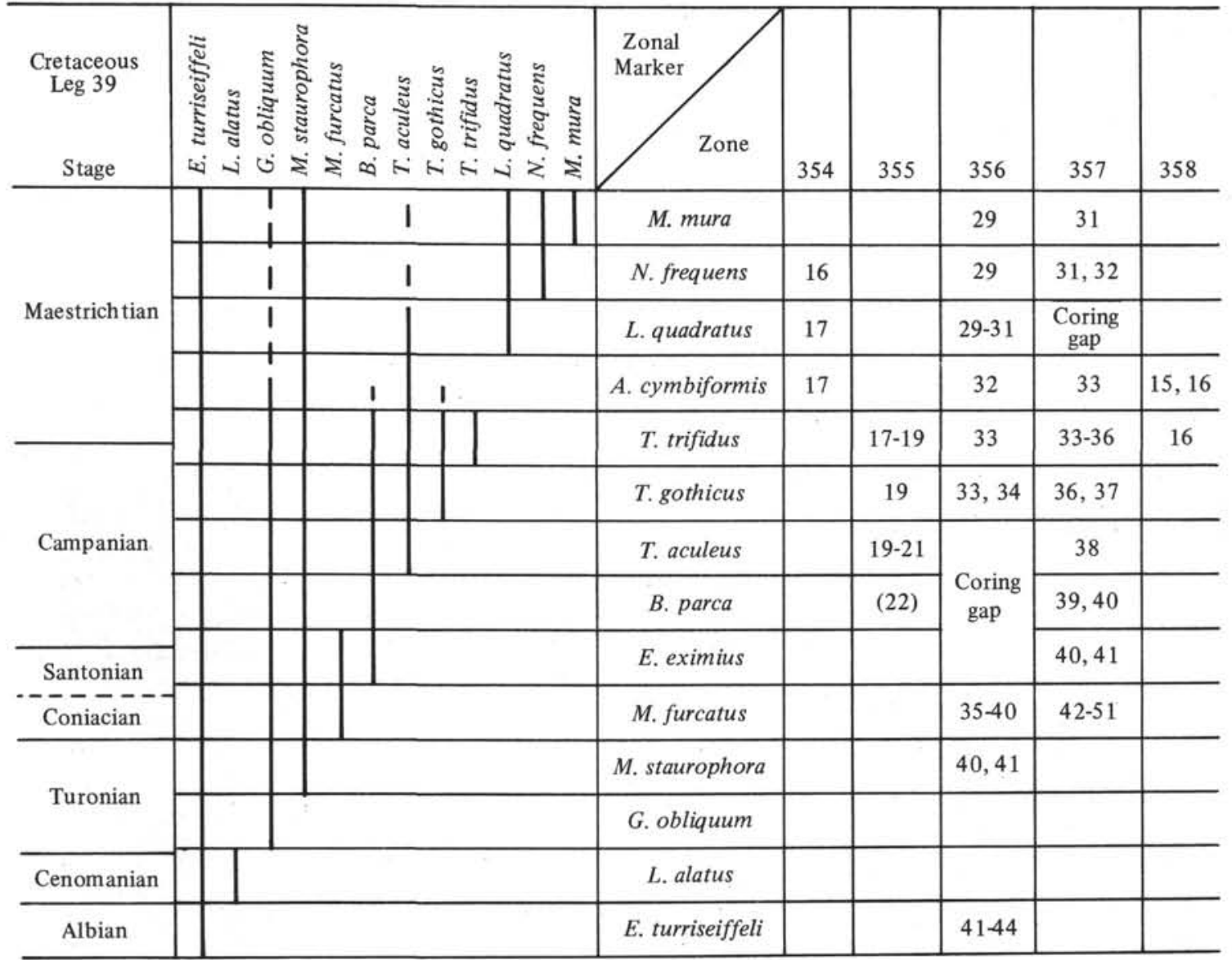

Stratigraphic position: Coniacian and Santonian.

Remarks: Definition of the $M$. furcatus Zone as the total range of $M$. furcatus has been suggested by Roth (1973), who also used the first occurrence of $B$. parca above the last occurrence of $M$. furcatus. At Site 357, it is the other way around, and at Site 356 the interval in question occurs in a coring gap. At Site 167, Roth (1973) also found rare $B$. parca together with $M$. furcatus. The $M$. furcatus Zone as defined here occurs at Sites 356 and 357.

Eiffellithus eximius Zone, Bukry and Bramlette, 1970, emend. this paper

Definition: Interval from the first occurrence of $B$. parca to the last occurrence of $M$. furcatus.

Stratigraphic position: Upper Santonian to lower Campanian.

Remarks: The overlapping occurrence of $M$. furcatus and B. parca, which was observed at Site 167 (Roth, 1973) and Site 357, was also found in the sections of El Kef and Pont du Fahs in Tunisia, where the last occurrence of $M$. furcatus seems to fall into the lowermost Campanian (defined by planktonic foraminifers). This zone falls within a coring gap at Site 356. Martini (1976) found that the last occurrence of $M$. furcatus coincides with the first occurrence of $B$. parca and T. aculeus in Core 315A-26. In the zonation proposed here, this would mean the occurrence of a hiatus in this core.

\section{Broinsonia parca Zone, Perch-Nielsen, this paper}

Definition: Interval from the last occurrence of $M$. furcatus to the first occurrence of Tetralithus aculeus.

Stratigraphic position: Lower Campanian.

Remarks: The $B$. parca Zone, as defined here, was found at Site 357, possibly at Site 355, and is missing or contained in a coring gap at Site 356. This zone is also missing in Core 315A-26 (Martini, 1976), but is present at Site 167 (Roth, 1973) and in the upper Cretaceous sections at El Kef and Pont du Fahs in Tunisia.

Tetralithus aculeus Zone, Cepek and Hay, 1969, emend. Martini, 1976

Definition: Interval from the first occurrence of $T$. aculeus to the first occurrence of $T$. gothicus.

Stratigraphic position: Lower Campanian.

Remarks: The T. aculeus Zone was found at Site 355 in the Brazil Basin and at Site 357; it is missing or contained in a coring gap at Site 356 . This zone was also found by Martini (1976) at Sites 315 and 316, and can be distinguished in the range chart of Roth (1973) for Site 167. 
TABLE 2

Age of Cretaceous Biohorizons According to Thierstein (1975) Martini (1976), and Van Hinte (1976)

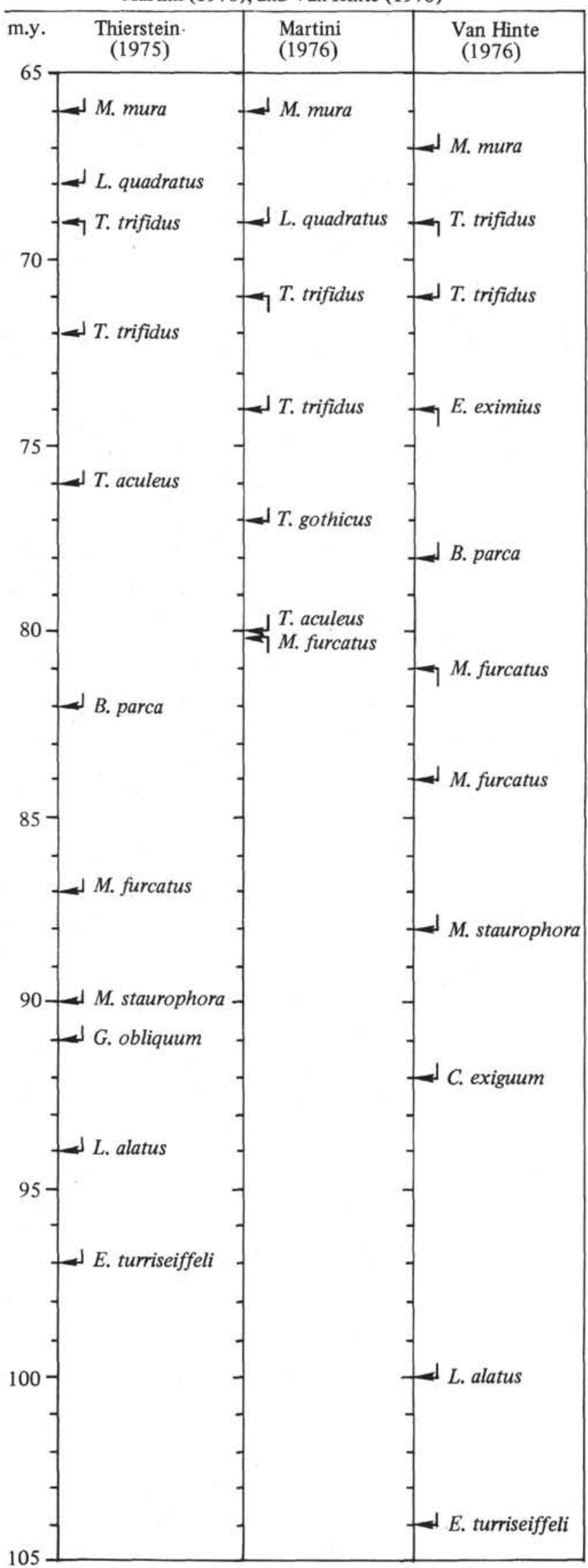

Tetralithus gothicus Zone, Martini, 1976

Definition: Interval from the first occurrence of $T$. gothicus to the first occurrence of $T$. trifidus.

Stratigraphic position: Middle Campanian.

Remarks: The T. gothicus Zone occurs at Sites 355, 356, and 357, and was found by Martini (1976) at Sites 315,316 , and 137. It is distinguished in the range charts of Sites 167 and 170 (Roth, 1973) and was found in the sections of El Kef and Pont du Fahs in Tunisia.

Tetralithus trifidus Zone, Bukry and Bramlette, 1970

Definition: Interval from the first to the last occurrence of $T$. trifidus.

Stratigraphic position: Upper Campanian and lower Maestrichtian.

Remarks: The $T$. trifidus Zone is easily recognizable in low latitudes, and was found at Site 355, where it is the youngest coccolith assemblage, at Sites 357 and 358, and at Site 21 of Leg 3, which is also in the western South Atlantic. It is widely represented in all oceans.

\section{Arkhangelskiella cymbiformis Zone Perch-Nielsen,} 1972, emend. Martini, 1976

Definition: Interval from the last occurrence of $T$. trifidus to the first occurrence of Lithraphidites quadratus.

Stratigraphic position: Lower to middle Maestrichtian.

Remarks: The $A$. cymbiformis Zone as defined here can only be recognized in low latitudes, since $T$. trifidus does not occur in high latitudes, where the last occurrence of Reinhardtites anthophorus or Broinsonia parca may be used as a lower boundary for this zone. The A. cymbiformis Zone was found at Site 354 on Ceará Rise, where it constitutes the oldest assemblage above the basalt. It was also found at Sites 356, 357, and 358 , where it is the youngest Cretaceous zone recovered.

Lithraphidites quadratus Zone Cepek and Hay, 1969, emend. this paper

Definition: Interval from the first occurrence of $L$. quadratus to the first occurrence of Nephrolithus frequens.

Stratigraphic position: Middle Maestrichtian.

Remarks: This zone was found at Sites 354 and 356. It is probably contained in a coring gap at Site 357, inasmuch as it was reported from nearby Site 20 of Leg 3.

Nephrolithus frequens Zone Cepek and Hay, 1969, emend. this paper

Definition: Interval from the first occurrence of $N$. frequens to the first occurrence of Micula mura.

Stratigraphic position: Upper Maestrichtian.

Remarks: It has been proposed that $M$. mura was restricted to low latitudes, $N$. frequens to high latitudes (Worsley and Martini, 1971). Though $N$. frequens is certainly much more common in high northern and southern latitudes, it has also been found in Egypt, at Site $354\left(6^{\circ} \mathrm{N}\right)$, Site $356\left(28^{\circ} \mathrm{S}\right)$, and Site $357\left(30^{\circ} \mathrm{S}\right)$. On the other hand, $M$. mura is much more common in low latitudes, but does occur as far north as Denmark, at 
$57^{\circ} \mathrm{N}$, in Kjölby Gaard (Perch-Nielsen, 1973). Where the two species were found together, $N$. frequens occurs slightly below the first occurrence of $M$. mura.

The $N$. frequens Zone as defined above was found at Sites 354,356 , and 357 . It is represented only by one sample at Site 354, but occurs in three sections at Site 356, and extends over more than a core at Site 357. At Site 357 , very rare specimens of $N$. frequens were found, even below the level of the first occurrence of $L$. quadratus. They are considered here to be contaminants.

\section{Micula mura Zone, Martini, 1969}

Definition: Interval from the first occurrence of $M$. mura to the last occurrence of $A$. cymbiformis and most other Cretaceous species.

Stratigraphic position: Uppermost Maestrichtian.

Remarks: The $M$. mura Zone was found at Sites 356 and 357, as well as at nearby Sites 20 and 21 of Leg 3. It is considered to represent the youngest Cretaceous coccolith assemblage, and most authors correlate it with the $N$. frequens Zone. It seems, however, that in the most complete sections at both low and high latitudes, $M$. mura is present, and its absence in most high latitude sections could/must be taken as an indication that the uppermost Cretaceous is missing, as seems to be the case in the type area of the Maestrichtian, where $M$. mura has not yet been found. I therefore prefer to distinguish the two zones wherever $N$. frequens is present, and to combine them in sections where only $M$. mura is found, since where they occur together, $N$. frequens is also found in the youngest samples, and can thus be considered to range to the top of the Cretaceous. This means that where $N$. frequens is found neither below $M$. mura nor with $M$. mura, this is a consequence of ecological conditions, not a hiatus, below the $M$. mura Zone.

\section{Correlation of Numerical Time Scale With Coccolith Zones}

Several authors have recently correlated Cretaceous coccolith zones with a numerical time scale. Three of these attempts are shown in Table 2 to illustrate the "state of the art." In most cases, the three authors do not correlate directly from a radiometrically dated sediment to its biostratigraphic content. There is always the detour through the stages, and an age is chosen from several available for stage boundaries. Then the position of first or last occurrence of zonal markers is chosen within the stage in which they are thought to occur. Since some markers are not found in the stratotypes of these stages, another detour via first and last occurrences of species present with the markers and at the stratotypes is necessary. This may be the best and thus far the only way to correlate biozones with a numerical time scale, but it certainly is not satisfactory. Because the adopted age of the Lower/Upper Cretaceous boundary varies from 94 m.y. in Thierstein (1975) to 100 m.y. in Van Hinte (1976), the length of the stages must vary, too. The relative length of the stages is different according to different authors. As Douglas and Bukry (1973) pointed out, there are simply not yet enough data from biostratigraphically well-defined horizons to satisfactorily allow us to assign precise age to biostratigraphic events, particularly as the data in hand can be interpreted as differently as shown in Table 2.

\section{Tertiary and Quaternary}

Generally the "standard calcareous nannofossil zonation" (Martini, 1971) was used for the Tertiary and Quaternary sequences recovered on Leg 39. Some deviations were necessary or desirable, however, and the biostratigraphic scheme proposed by Bukry (1973c) was used to refine the subdivisions of some parts of the sequence, or to combine parts that could not be subdivided as finely as Martini (1971) proposed. In doing this, the significance of the absence of one or several zones is always a matter of judgment. Is it a hiatus, with some time-slice not represented by sediment; or is the absence of a specific zone due to an ecological absence of the defining species? Sometimes the answer can be found in data derived from the foraminifers or the radiolarians. Sometimes a change in lithology suggests a hiatus, but most often, the experience of the observer is the only guide.

Table 3 shows the zones used and the biostratigraphic distribution of the cores recovered.

In the following, remarks are made as to the usage of the zone, where this differs from Martini's "Standard Zonation," or wherever remarks seem useful. It can be argued whether it is wise to alter definitions of a "standard zonation," because in doing so, we again alter the content of a given zone and make it less correlatable. Although biostratigraphers may or may not realize that NP XY of author A may be different from NP XY of author B or C (or author A two years later), those who simply use our information to date magnetic anomalies, correlate sequences over large distances, or find continuous sequences or define hiatuses, will not be aware of these vagaries. A zonal name without the name of its author and the year of its definition means little, since the same names have been used for different intervals. For example, the $C$. tenuis Zone of Bukry, 1973c, includes the interval from the first $C$. tenuis to the first $F$. tympaniformis, which in Martini's zonal system means the $C$. tenuis Zone NP2, the $C$. danicus Zone NP3, and the E. macellus Zone NP4, and leaves out the very bottom of the Tertiary, the $M$. inversus Zone NP1; thus, what shows up as a missing section in Martini's zoning looks like a continuous sequence in Bukry's. Hay (1972) and Worsley and Jorgens (1974) have shown with probabilistic stratigraphy that we cannot expect to refine ad infinitum long-distance correlation of short time intervals represented by biostratigraphically defined zones. The "standard zonation," or any zonation including results from different environments, will need "amendments" if applied in a different area than the one from which it was extracted. It seems important to point out to biostratigraphers and to geologists who use their results that the exact time of deposition of a given sediment will never be known.

\section{Markalius inversus Zone, NP1}

Remarks: It is usually easy to recognize the Cretaceous/Tertiary boundary in sequences where it is 


\section{K. PERCH-NIELSEN}

TABLE 3

Zonal Assignment and Age of Cores and Sections Based on Calcareous Nannofossils

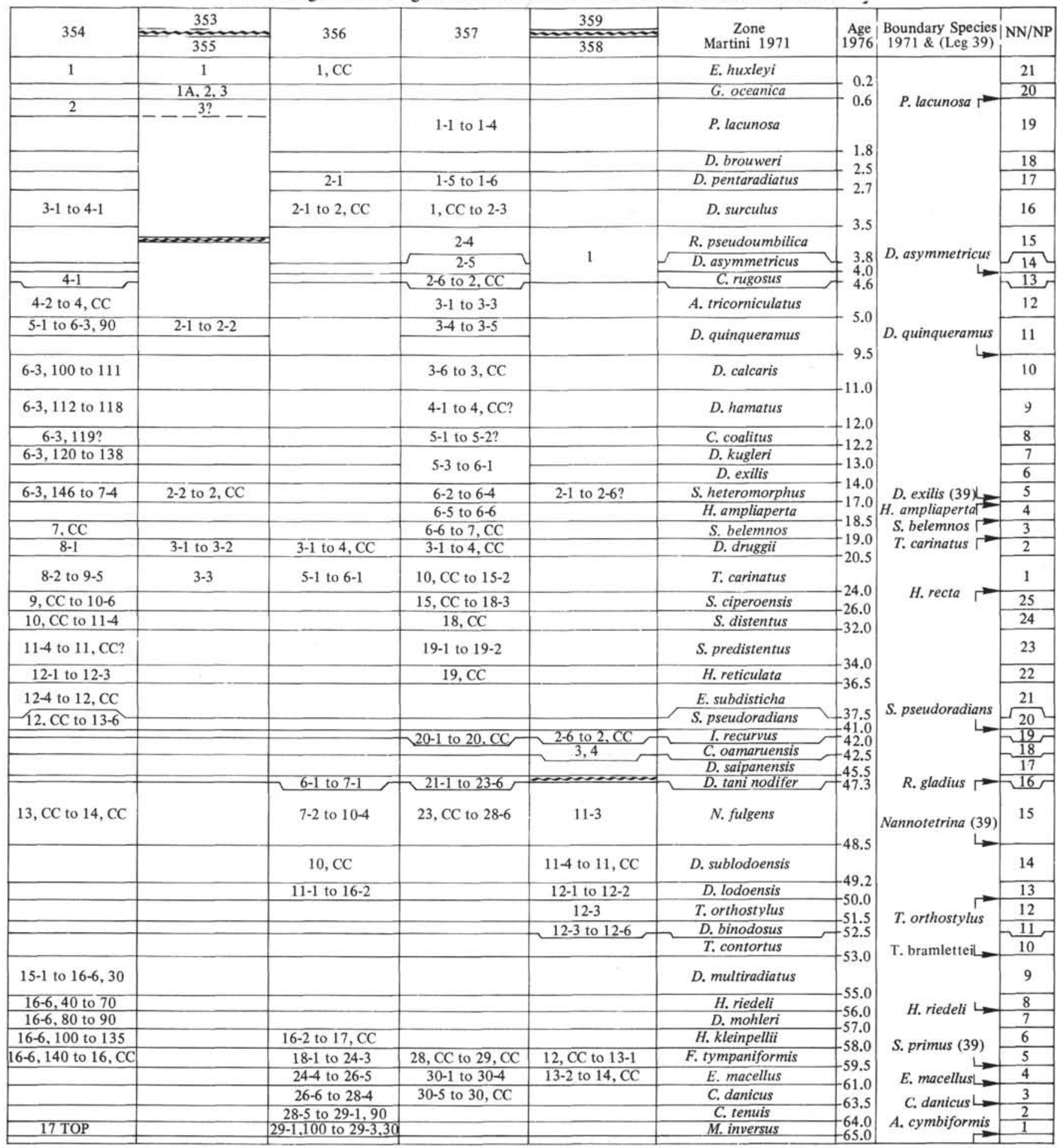

Note: Zonal schemes of Martini (1971) and Bukry $(1973,1974$, and 1975). See also remarks to zonal assignments in the text. $*=$ appearance, $\dagger=$ disappearance, $\mathrm{A}^{*}$ = beginning of acme, $\mathrm{A} \dagger=$ end of acme, $\mathrm{M}=$ also boundary species in Martini (1971), (39) boundary species used in Leg 39 report, where not $M$.

marked by an unconformity and where not too many Upper Cretaceous coccoliths are reworked into the Paleocene. In sequences like the one at Site 356, however, where no biostratigraphically resolvable hiatus could be detected, determining the lower limit of the $M$. inversus Zone as the oldest Tertiary zone can be tricky if the definition of NP1 is taken verbally, since it is impossible to distinguish reworked Cretaceous coccoliths from Cretaceous coccoliths in place. Cretaceous coccoliths occur in varying amounts in 
TABLE 3 - Continued

\begin{tabular}{|c|c|c|c|c|c|}
\hline Age & $\begin{array}{c}\text { Zone } \\
\text { (Bukry, 1975) }\end{array}$ & Subzone & Boundary Species & $\begin{array}{c}\text { Boundary } \\
(m . y .)\end{array}$ & $\begin{array}{c}\text { Duration } \\
(\mathrm{m} . \mathrm{y} .)\end{array}$ \\
\hline \multirow{5}{*}{ 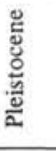 } & \multicolumn{2}{|l|}{ Emiliania huxleyi } & E. huxleyi* ${ }^{*} \mathrm{M}$ & 0.2 & 0.2 \\
\hline & \multirow{2}{*}{$\begin{array}{l}\text { Gephyrocapsa } \\
\text { oceanica }\end{array}$} & Ceratolithus cristatus & E. ovata ${ }^{\dagger}, E$. annula & 0.3 & 0.1 \\
\hline & & Emiliania ovata & G. oceanica* ${ }^{*}$ & 0.9 & 0.6 \\
\hline & \multirow{2}{*}{$\begin{array}{l}\text { Crenalithus } \\
\text { doronicoides }\end{array}$} & Gephyrocapsa caribbeanica & G. caribbeanica* & 1.6 & 0.7 \\
\hline & & Emiliania annula & D. brotuweri $\mathrm{M}$ & & 0.2 \\
\hline \multirow{7}{*}{ 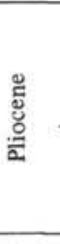 } & \multirow{4}{*}{$\begin{array}{r}\text { Discoaster } \\
\text { brouweri }\end{array}$} & Cyclococcolithina macintyrei & D. pentaradiatus $\dagger \mathrm{M}$ & $\frac{1.0}{2.0}$ & 0.2 \\
\hline & & Discoaster pentaradiatus & D. surculus $\dagger \mathrm{M}$ & 2.1 & 0.1 \\
\hline & & Discoaster surculus & D. tamalis $\dagger$ & 2.5 & 0.4 \\
\hline & & Discoaster tamalis & R.pseudoumbilica $\dagger$ M, S. neoabies $\dagger$ & 3.0 & 0.5 \\
\hline & \multirow{2}{*}{$\begin{array}{l}\text { Reticulofenestra } \\
\text { pseudoumbilica }\end{array}$} & Discoaster asymmetricus & D. asymmetricus $\mathrm{A}^{*}$ & 3.5 & 0.5 \\
\hline & & Sphenolithus neoabies & C. primus $\dagger$, C. tricorniculatus $\dagger \mathrm{M}$ & 4.0 & 0.5 \\
\hline & \multirow{2}{*}{$\begin{array}{l}\text { Ceratolithus } \\
\text { tricorniculatus }\end{array}$} & $\begin{array}{l}\text { Ceratolithus rugosus } \\
\text { Ceratolithus gcusus }\end{array}$ & C. rugosus $* \mathrm{M}, C$. acutus $\dagger$ & 4.4 & 0.4 \\
\hline \multirow{14}{*}{ 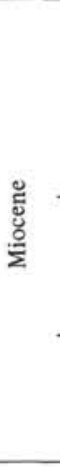 } & & $\begin{array}{l}\text { Ceratolithus acutus } \\
\text { Triquetrorhabdulus rugosus }\end{array}$ & C. acutus*, T. rugosus ${ }^{\dagger}$ & 5.0 & 0.6 \\
\hline & \multirow{2}{*}{$\begin{array}{l}\text { Discoaster } \\
\text { quinqueramus }\end{array}$} & $\begin{array}{l}\text { Triquetrorhabdulus rugosus } \\
\text { Ceratolithus primus }\end{array}$ & D. quinqueramus $\div \mathrm{M}$ & 5.6 & $\frac{0.6}{1.0}$ \\
\hline & & Discoaster berggrenii & C. primus* & 6.6 & $\frac{1.0}{0.4}$ \\
\hline & \multirow{2}{*}{$\begin{array}{l}\text { Discoaster } \\
\text { neohamatus }\end{array}$} & Discoaster neorectus & D. berggrenii $*$, D. surculus ${ }^{*}$ & 7.0 & 0.5 \\
\hline & & Discoaster bellus & D. neorectus ${ }^{*}, D$. loeblichii ${ }^{*}$ & 7.5 & 3.5 \\
\hline & \multirow{3}{*}{$\begin{array}{l}\text { Discoaster } \\
\text { hamatus }\end{array}$} & Catinaster calyculus & D. hamatus $\dagger \mathrm{M}$ & 11.0 & 1.0 \\
\hline & & Helicopontosphaera kamptneri & C. calyculus* $\mathrm{M}$ & $\frac{12.0}{130}$ & 1.0 \\
\hline & & Catinaster coalitus & & $\frac{13.0}{13.2}$ & 0.2 \\
\hline & \multirow{2}{*}{$\begin{array}{l}\text { Discoaster } \\
\text { exilis }\end{array}$} & Discoaster kugleri & & $\frac{13.2}{13.4}$ & 0.2 \\
\hline & & Coccolithus miopelagicus & $\begin{array}{l}\text { D. kugleri* } \mathrm{M}, C \text {. floridanus }{ }^{\dagger} \\
\text { S. heteromorphus }{ }^{\dagger} \mathrm{M}\end{array}$ & $\begin{array}{l}13.4 \\
14.0\end{array}$ & 0.6 \\
\hline & \multirow{2}{*}{\multicolumn{2}{|c|}{$\begin{array}{l}\text { Sphenolithus heteromorphus } \\
\text { Helicopontosphaera ampliaperta }\end{array}$}} & C. macintyre $i^{*}, D$. deflandrei $\mathrm{A} \dagger$ & 15.0 & 1.0 \\
\hline & & pliaperta & S. heteromorphus* & 17.0 & 2.0 \\
\hline & \multicolumn{2}{|c|}{ Sphenolithus belemnos } & S. belemnos* (39) & 18.0 & 1.0 \\
\hline & \multirow{3}{*}{$\begin{array}{l}\text { Triquetrorhabdulus } \\
\text { carinatus }\end{array}$} & Discoaster druggii & D. druggii ${ }^{*} \mathrm{M}$ & 21.0 & 3.0 \\
\hline \multirow{8}{*}{ 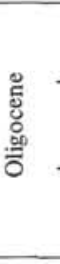 } & & $\begin{array}{l}\text { Discoaster deflandrei } \\
\text { Cyclicargolithus abisectus }\end{array}$ & C. abisectus $\mathrm{A} t$ & 23.0 & 2.0 \\
\hline & & $\begin{array}{l}\text { Cyclicargolithus abisectus } \\
\text { Dictyococcites bisectus }\end{array}$ & S. ciperoensis $\dagger(39), D$. bisectus $\dagger$ & 24.0 & 1.0 \\
\hline & $\begin{array}{l}\text { Sphenolithus } \\
\text { ciperoensis }\end{array}$ & $\begin{array}{l}\text { Dictyococcites bisectus } \\
\text { Cyclicargolithus floridanus }\end{array}$ & S. distentus $\div \mathrm{M}$ & 25.0 & 1.0 \\
\hline & Sphenolithus distent & Cyclicargolithus floridanus & S. ciperoensis* M & 26.5 & 1.5 \\
\hline & Sphenolithus predist & & S. distentus* & 30.0 & 3.5 \\
\hline & & Reticulofenestra hillae & R. hillae ${ }_{\dagger}^{\dagger}$, R. umbilica $\dagger \mathrm{M}$ & 34.0 & 4.0 \\
\hline & $\begin{array}{l}\text { Helicopontosphaera } \\
\text { reticulata }\end{array}$ & Coccolithus formosus & C. formosust $\mathrm{M}$ & 34.5 & $\frac{0.5}{2.5}$ \\
\hline & & Coccolithus subdistichus & C. subdistichus $\mathrm{A} \dagger$ & 37.0 & $\frac{2.3}{1.0}$ \\
\hline & Discoaster & Isthmolithus recurvus & D. barbadiensis $\dagger, D$. saipanensis $\dagger \mathrm{M}$ & 38.0 & 3.0 \\
\hline & barbadiensis & Chiasmolithus oamaruensis & 1. recurvus* $\mathrm{M}$ & 41.0 & 1.0 \\
\hline & Reticulofenestra & Discoaster saipanensis & $\begin{array}{l}\text { C. grandis } \dagger, C \text {. oamaruensis* } \mathrm{M} \\
\text { C. solitus } \dagger \mathrm{M}, \bar{D} \text {. bifax } \dagger\end{array}$ & $\frac{42.0}{44.0}$ & 2.0 \\
\hline & umbilica & Discoaster bifax & $\begin{array}{l}\text { C. solitus } \dagger \mathrm{M}, D \text {. bifax } \dagger \\
\text { R. umbilica }{ }^{*}, D \text {. bifax }\end{array}$ & $\frac{44.0}{45.0}$ & 1.0 \\
\hline & & Coccolithus staurion & C. gigast & $\begin{array}{l}45.0 \\
46.5\end{array}$ & 1.5 \\
\hline 气ू̆ & quadrata & Chiasmolithus gigas & C. gigas* & 47.0 & 0.5 \\
\hline ठั & & Discoaster strictus & $N$. quadrata* $\mathrm{M}, R$. inflata ${ }^{\dagger}$ & 48.0 & 1.0 \\
\hline & Discoaster & Rhabdosphaera inflata & R. inflata ${ }^{*}$ & 49.0 & 1.0 \\
\hline & sublodoensis & Discoasteroides kuepperi & D. sublodoensis* $\mathrm{M}$ & 49.5 & 0.5 \\
\hline & Discoaster lodoensis & & C. crassus ${ }^{*}$ & 50.0 & 0.5 \\
\hline & Tribrachiatus orthos & & D. lodoensis* $\mathrm{M}$ & 52.0 & 2.0 \\
\hline & Discoaster & Discoaster binodosus & T. contortus $\dagger \mathrm{M}$ & 52.8 & 0.8 \\
\hline & diastypus & Tribrachiatus contortus & D. diastypus ${ }^{*}, T$. contortus ${ }^{*}$ & 53.5 & 0.7 \\
\hline & Discoaster & Campylosphaera eodela & C. eodela* & 54.0 & 0.5 \\
\hline & multiradiatus & Chiasmolithus bidens & D. multiradiatus ${ }^{*} \mathrm{M}$ & 55.0 & 1.0 \\
\hline & $\begin{array}{l}\text { Discoaster nobilis } \\
\text { Discoaster mohleri }\end{array}$ & & D. nobilis* (39) & 55.5 & 0.5 \\
\hline & & & D. mohleri* $\mathrm{M}$ & 57.0 & $\frac{1.5}{1.0}$ \\
\hline$\stackrel{0}{0}$ & $\begin{array}{l}\text { Heliolithus kleinpelli } \\
\text { Fasciculithus tympar }\end{array}$ & ormis & H. kleinpellii* $\mathrm{M}$ & 58.0 & $\frac{1.0}{2.0}$ \\
\hline ฮี & Cruciplacolithus tent & & F. tympaniformis ${ }^{*} \mathrm{M}$ & 60.0 & 3.0 \\
\hline & & & C. tenuis ${ }^{*} \mathrm{M}$ & 63.0 & \\
\hline
\end{tabular}

most Danian sequences. One criterion for recognizing the boundary is the frequency of Thoracosphaera, which usually increases sharply in the lowermost Tertiary. In the area of the type Danian, Thoracosphaera appears in the lowermost Danian (extremely rare occurrences only were recorded from the uppermost Maestrichtian) and reaches rock forming amounts in the upper Danian of this area. In the sequence at Biarritz, where Thoracosphaera also occurs in the upper Maestrichtian, it increases markedly at the Cretaceous/Tertiary boundary and it does the same at the sites drilled on Leg 39. The presence of relatively more $M$. inversus, $M$. reinhardtii, Biscutum sp., and Crepidolithus sp. than in the underlying Maestrichtian can also be used as a guide for lowermost Danian in sequences where reworked 
Cretaceous forms are common. The first occurrence of $B$. sparsus is a good guide to the base of the $M$. inversus Zone, too, but since $B$. sparsus never occurs more commonly than rare specimens and seems to be missing in some sequences, the absence of B. sparsus means nothing.

The upper boundary of NP1 is defined by the first occurrence of $C$. tenuis. In the literature, usually all elliptical coccoliths with a cross whose bars are aligned with the axes of the form are called $C$. tenuis. There are, however, at least three different forms thus collected under this name: small forms with a relatively large central opening and relatively slender bars of the central cross, C. primus n. sp.; larger forms with a relatively small opening in the central area $(C$. tenuis $\mathbf{s}$. st.) and still larger forms with small "feet" at the ends of the bars were assigned to C. notus $\mathrm{n}$. sp. They appear in the order they are mentioned here. The upper boundary of NP1 and thus lower boundary of NP2, the C. tenuis Zone, was here set at the first occurrence of the middle form, which seems to correspond best to the C. tenuis as described by Stradner (1961), who mentioned the size of $C$. tenuis to be 8-10 microns and, in the original drawing, did not show any thickening of the bars towards their ends.

The $M$. inversus Zone is missing in many lower Paleocene sequences, also in some sections in the type area of the Danian in Denmark. When present, its thickness rarely reaches more than one to a few meters.

\section{Cruciplacolithus tenuis Zone, NP2}

Remarks: For the definition of the lower boundary see NP1, for the upper boundary NP3. The C. tenuis Zone is missing in many lower Paleocene sequences, also in some sections in the type area of the Danian. It is rarely more than one to a few meters thick.

\section{Chiasmolithus danicus Zone, NP3 and NP4, E. macellus Zone}

Remarks: The lower boundary of the $C$. danicus Zone, the first occurrence of $C$. danicus, can be difficult to assign precisely in continuous sequences, since forms intermediate between $C$. tenuis and $C$. danicus occur, where the central cross is slightly rotated from the position parallel to the axes to a position parallel to the diagonals. Thus the lower boundary was here set where the first clearly distinguishable $C$. danicus occurred.

The upper boundary of NP3 has been defined at the first occurrence of $E$. macellus. Since $E$. macellus is absent in assemblages affected by dissolution and in high latitudes, Martini (1976) used a combined NP3/4 ranging from the first occurrence of $C$. danicus to the first occurrence of $F$. tympaniformis. In this paper, this was necessary at Site 358 , where E. macellus is also absent in the overlying $F$. tympaniformis Zone. At the other sites NP3 and NP4 could be distinguished. Other coccoliths might be useful for the zonation of the NP3/NP4 interval: Neochiastozygus imbriei occurs at Sites 356 and 357 towards the top of NP3 and reaches into the lowermost part of NP4. Shortly above, also at both these sites, the first occurrence of Fasciculithus magnus can be observed. The two species were not observed together at these two sites. F. magnus is about twice the size of "normal" fasciculiths like $F$. tympaniformis, whose first occurrence defines the top of NP4. This definition now proves not to be very satisfactory, since $F$. tympaniformis is not the first fasciculith to occur. The first occurrence of Sphenolithus primus, the first sphenolith, might be a better choice for this zonal boundary, since it occurs at about the same time as $F$. tympaniformis or slightly before. This would provide a stratigraphically more even plane than $F$. tympaniformis, which, in the literature, usually includes any "first fasciculith" and thus might set the boundary almost down to the NP3/4 boundary.

\section{F. tympaniformis Zone, NP5}

Remarks: Due to the reasons mentioned above, the base of the $F$. tympaniformis Zone was taken at the base of $S$. primus, which, on Leg 39, coincided with the base of small fasciculiths, but sometimes was somewhat below the base of the actual $F$. tympaniformis.

\section{H. kleinpellii Zone, NP6 to D. multiradiatus Zone, NP9}

Remarks: The first occurrence of $H$. kleinpellii at the base of NP6 is easily recognizable at Sites 354 and 356. But the subdivision of the very condensed sequence containing all late Paleocene zones in about $100 \mathrm{~cm}$ of Section 354-16-6 is more difficult. Bioturbation might be responsible for some of the mixing down of very rare discoasters in the H. kleinpellii Zone. D. mohleri is used instead of D. gemmeus to define the base of NP7 and $D$. nobilis instead of $H$. riedeli, which was not found, to define the base of NP8. Rare specimens of D. multiradiatus also were found below the interval assigned to NP9 and are thought to be displaced by bioturbation. Core 354-15 and Sections 354-16-1 through 6 are assigned to the D. multiradiatus Zone. While this assignment is certain for Core 16 , it seems more doubtful for Core 15, where the assemblage includes fewer $D$. multiradiatus and no or extremely rare fasciculiths, which are common in Core 16. But no typical lower Eocene forms like $T$. contortus or T. nunnii are present, either, in Core 15. The T. contortus Zone, NP10, is one of the two Paleogene zones not encountered on Leg 39, the other being NP17, the Discoaster saipanensis Zone of late Eocene age.

\section{Discoaster binodosus Zone, NP11 to Discoaster sublodoensis Zone, NP14}

Remarks: The top of the $D$. binodosus Zone and base of the $T$. orthostylus Zone are marked by the first occurrence of D. lodoensis. At Site 358, single specimens of $D$. lodoensis were found three sections below the first common occurrence of $D$. lodoensis, where the zonal boundary was set. Likewise, rare $T$. orthostylus do occur above the last common occurrence of this species, where the zonal boundary between NP12 and NP13 was set. In fact, $T$. orthostylus occurs as high as in NP15 at Site 356. D. sublodoensis is either rare or hardly recognizable due to poor preservation at Sites 356 and 358, thus the lower boundary of the $D$. sublodoensis Zone, NP14, is difficult to define exactly. 


\section{Nannotetrina fulgens Zone, NP15 and} D. tanii nodifer Zone, NP16

Remarks: It is here suggested and was here undertaken to define the base of the $N$. fulgens Zone by the first occurrence of the genus Nannotetrina rather than the first occurrence of any of the species of the genus. Due to heavy overgrowth or dissolution, the species can often not be distinguished at all, but the presence of the genus can be established even in very poorly preserved material. Using this definition for the $N$. fulgens Zone, Bukry's $R$. inflata Subzone (1973c) correlates with the base of the $N$. fulgens Zone rather than with the top of the $D$. sublodoensis Zone.

The top of the $N$. fulgens Zone was defined by Martini at the last occurrence of $R$. gladius, which was not found in Leg 39 material. Instead, the first occurrence of D. bifax was used at Site 356 and the last occurrence of Nannotetrina sp. at Site 357, where D. bifax occurs only sporadically.

\section{Discoaster saipanensis Zone, NP17 to S. pseudoradians Zone, NP20}

Remarks: Martini (1976) has recently proposed combined zones of NP17/18 and NP19/20. NP17, as defined by Martini (1971), was not encountered on Leg 39. NP18, on the other hand, might be present at Site 359, if it is defined as by Martini (1971), and the single specimen of $I$. recurvus taken as a contamination in Sample 4-1, Top. According to the new definition of the combined NP17/18, from the last occurrence of $C$. solitus to the last occurrence of $C$. grandis, the interval NP17/18 is not represented at Leg 39 sites.

The combined NP19/20 zone (Martini, 1976) is defined as the interval' from the last occurrence of $C$. grandis to the last occurrence of $D$. saipanensis. This interval was found at Sites 354, 357, and 359. The distinction between NP19 and NP20 was made at Site 354 , where $I$. recurvus is absent but $S$. pseudoradians consistently present, thus the samples were assigned to NP20. At Site 357, I. recurvus is present but $S$. pseudoradians absent and the interval was assigned to NP19. At Site $359, S$. pseudoradians is only very rare in one sample and the interval was assigned to NP18, since it is below the common occurrence of $I$. recurvus which, at this relatively high latitude site should be a reliable zonal marker.

\section{Ericsonia subdisticha Zone, NP21 to Sphenolithus ciperoensis Zone, NP25}

Remarks: Generally, the Oligocene sequences at Sites 354 and 357 could be zoned easily with the zonal scheme proposed by Martini (1971).

The coccolith assemblages in the Oligocene at Site 354 in the equatorial North Atlantic and Site 357 at $30^{\circ} \mathrm{S}$ in the South Atlantic are, as could be expected, quite different. The latitudinal differences are reflected by the frequency of chiasmoliths and Prinsiaceae, which are more common in higher latitudes and Helicopontosphaera, sphenoliths and discoasters which are more common in low latitudes.

At Site 357, the Prinsiaceae are common throughout, Chiasmolithus altus occurs consistently and $C$. oamaru- ensis in the lower part of the Oligocene sequence. At Site 354 , only $C$. floridanus is common of the Prinsiaceae and no chiasmoliths occur at all. Helicopontosphaera, sphenoliths, and discoasters are more common at Site 354 than at Site 357. Triquetrorhabdulus carinatus and $T$. milowi were found at both sites in the uppermost part of the Oligocene. Braarudosphaeraceae only occur at Site 357 on the Rio Grande Rise, where $Z$. bijugatus also occurs, few to common, while it is sporadically rare at Site 354 . This reflects the greater depth of deposition during the Oligocene at Site 354 which is further suggested by the sporadically scarce occurrence of Pontosphaera at Site 354, while it is quite consistently present at Site 357 . Thus both the different latitudes as well as the different depths of deposition at the two sites are reflected in the coccolith assemblages.

NP21 was only recognized in the lower part of Core 354-12, where Ericsonia subdisticha, E. obruta, and E. formosa are rare. NP22, the Helicopontosphaera reticulata Zone was recovered in the upper part of Core 354-12 and in the core catcher of Core 357-19. At both these sites, NP23, the Sphenolithus predistentus Zone was also found and the last consistent occurrence of $H$. compacta was observed at the top of this zone, just below the first occurrence of $S$. ciperoensis, which defines the top of the zone. Also NP24, the $S$. distentus Zone, was found at both sites, as was NP25, the $S$. ciperoensis Zone. For NP25, the last occurrence of $S$. ciperoensis was used to define the top of the zone, since $H$. recta occurs only sporadically in the two sequences. The same was proposed by Bukry (1973c) and Martini (1976) for the central Pacific.

\section{Triquetrorhabdulus carinatus Zone, NN1}

Remarks: The last occurrence of $S$. ciperoensis was used to define the top of NP25 and the base of NN1 (see above). Generally the last occurrence of $Z$. bijugatus and $D$. bisecta, which are used in high latitudes to define the Oligocene/Miocene boundary, occur only slightly above the last $S$. ciperoensis in the lower part of NN1. The $T$. carinatus Zone was found at Sites 354 through 357 and was generally a time of fast accumulation of sediments on positive features.

\section{Discoaster druggii Zone, NN2 and $\mathrm{S}$. belemnos Zone, NN3}

Remarks: According to Martini (1971), the last occurrence of $T$. carinatus defines the top of NN2, in which $S$. belemnos is already present. Since $T$. carinatus disappears before the first occurrence of $S$. belemnos at Site 357, the first occurrence of $S$. belemnos was taken as the base of the $S$. belemnos Zone and the top of the D. druggii Zone at this site. At Site 354, S. belemnos was only found in Sample 7, CC, where T. carinatus is rare, while it is common below, where no $S$. belemnos occurs. Sample 7, CC was also assigned to NN3. At Site 355, few $S$. belemnos were found together with few $T$. carinatus and the assemblages were assigned to $\mathrm{NN} 2$, as were those at Site 356, where sporadic rare $T$. carinatus occur together with $S$. cf. $S$. belemnos. It might be wiser not to distinguish the two zones at all and, in areas 
where discoasters are rare, to lump them together with NN1, since $D$. druggii might be a poor stratigraphic indicator in such assemblages, which are mainly those from high latitudes. After the last occurrence of $S$. ciperoensis at the top of NP25, the last occurrence of $S$. belemnos at the top of NN3 seems the next generally reliable biostratigraphic event in the material studied here.

\section{Helicopontosphaera ampliaperta Zone, NN4 and} Sphenolithus heteromorphus Zone, NN5

Remarks: Martini (1976) has suggested a combined $\mathrm{NN} 4 / 5$ Zone in areas where $H$. ampliaperta, the last occurrence of which usually defines the top of NN4, is absent and Discoaster exilis, the first occurrence of which could define the same boundary, is not recognizable due to poor preservation. $H$. ampliaperta was not found in the material studied here, but $D$. exilis could be recognized and thus the two zones were distinguished. On the other hand, the last occurrence of H. euphratis, shown by Haq (1973) to be coeval with the last occurrence of $H$. ampliaperta, was found to occur high above the first occurrence of D. exilis at Sites 354, 355 , and 357 .

\section{Discoaster exilis Zone, NN6 and Discoaster kugleri Zone, NN7}

Remarks: The interval represented by NN6 and NN7 was only recovered at Sites 354 and 357 . At Site 354 , the middle Miocene sequence is very condensed and NN6 is either missing or contained in an unsampled $8 \mathrm{~cm}$ interval. At Site 357, NN6 and NN7 were not distinguished due to the generally very low frequency of discoasters at this site during the middle Miocene. Thus at Site 357, the base of NN6 was taken at the last occurrence of $S$. heteromorphus but the top of $\mathrm{NN} 7$ at the last occurrence of $C$. miopelagicus, the last occurrence of which occurs in the C. coalitus Zone, NN8 according to Bukry (1973c).

\section{Catinaster coalitus Zone, NN8 to Discoaster quinqueramus Zone, NN11}

Remarks: The interval from NN8 through NN10, the Discoaster calcaris Zone, was recovered at Site 354, where the sequence is very condensed and at Site 357, where the sequence is partly devoid of age diagnostic nannofossils. While the standard zones are readily recognizable at Site 354 , the overgrowth on discoasters makes this more difficult at Site 357 . The best stratigraphic marker in the upper Miocene at Site 357 is the first occurrence of ceratoliths, which is suggested by Bukry (1973c) to occur in NN11, the D. quinqueramus Zone. The latter zone was also found at Sites 354 and 355 , where the first ceratoliths also occur together with the first $D$. quinqueramus.

\section{Amaurolithus tricorniculatus Zone, NN12 to Emiliania huxleyi Zone, NN21}

Remarks: No complete Pliocene and Pleistocene sequence was recovered during Leg 39 and the zoning of the sediments of this age presented no major problems. The presence of E. huxleyi was checked by
SEM at all sites where the presence of the E. huxleyi Zone is indicated (see Table 3).

\section{Correlation of Numerical Time Scale With Coccolith Zones}

The ages assigned to the zonal boundaries in the Tertiary are those suggested by Bukry (1973b, Leg 16), except for an age of $53.5 \mathrm{~m} . \mathrm{y}$. assigned here to the Paleocene/Eocene boundary and an age of $65 \mathrm{~m} . \mathrm{y}$. to the Cretaceous/Tertiary boundary, where Bukry suggested 53 m.y. and 63 m.y., respectively. In Table 1, the ages suggested recently by Martini (1976) are also shown to illustrate the degree of uncertainty in the correlation of some coccolith zones and the numerical time scale (see also discussion under Cretaceous). The wish and need to assign the coccolith or any other zones a definite age in years is mainly due to the wish to calculate sedimentation rates, rates of evolution, etc. In order to calculate, i.e., the sedimentation rate at a certain site, we need to know the duration of the zones. All kinds of "devices" are used to, at best, estimate the duration of the zones, such as assuming a constant rate of sedimentation over a certain period of time at a certain site or correlation of zones with radiometrically dated and paleomagnetically analyzed sequences. The latter seems to be very promising and has probably furnished the best results so far, i.e., in Gartner (1973), Berggren and Van Couvering (1974), and Berggren (1973).

\section{SITE SUMMARIES}

Each site drilled on Leg 39 is discussed separately below. Table 3 shows all coccolith zones found at these sites. Tables 4-22 contain the distribution of calcareous nannofossils in all samples studied by light microscope. The reliability of first and last occurrences of the different species recorded varies. With the high number of species and the high number of samples studied and limited time available, it was impossible to pick up the exact ranges of all as well as the occurrence of the rare or very rare species.

\section{Site 353 (Holes 353, 353A, and 353B)—Vema Fracture Zone}

Site 353 was drilled at a water depth of 5165 meters in the Vema Fracture Zone. The eight Pleistocene samples examined from the three holes drilled and the calcareous nannofossils they contain are listed in Table 4. The uppermost sample was taken from some mud attached to the core liner, since no sediments were recovered in Core 353-1. It includes an assemblage of the late Pleistocene E. huxleyi Zone (NN21). Deposition near the CCD is indicated by the presence of only solution-resistant forms in this sample, which also contains few reworked coccoliths. The three samples studied from the turbidite sands and clays in Core 353-2 belong to the G. oceanica Zone (NN20) and also include delicate species, indicating their transport from shallower depths. A considerable quantity of reworked discoasters and coccoliths was found in the gray clay and the cream-colored layer at Sample 2-2, 54 $\mathrm{cm}$, while the core-catcher sample of this core included fewer reworked specimens. Reworking of Neogene 
TABLE 4

Distribution of Calcareous Nannofossils in the Pleistocene at Site 353

\begin{tabular}{|c|c|c|c|c|c|c|c|c|}
\hline & Age & & & Pleis & tocer & ene & & ? \\
\hline & Zone & $\begin{array}{l}\bar{\lambda} \\
z\end{array}$ & 永 & & $\begin{array}{l}\frac{\sigma}{Z} \\
z \\
z \\
\varrho\end{array}$ & & z & \\
\hline & $\begin{array}{l}\text { Depth Below } \\
\text { Sea Floor } \\
\text { (m) }\end{array}$ & 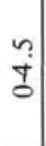 & & $\begin{array}{l}\stackrel{\infty}{\dddot{1}} \\
\stackrel{\leftrightarrow}{\infty} \\
=\end{array}$ & & $\frac{n}{\stackrel{n}{2}}$ & $\frac{\vec{\infty}}{0}$ & $\begin{array}{l}\infty \\
\infty \\
\infty \\
0 \\
0\end{array}$ \\
\hline & $\begin{array}{c}\text { Sample } \\
\text { (Interval in } \mathrm{cm} \text { ) }\end{array}$ & - & $\begin{array}{l}\dot{n} \\
\text { in } \\
\text { in }\end{array}$ & $\begin{array}{l}\stackrel{+}{n} \\
\text { ì }\end{array}$ & & & 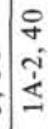 & $\stackrel{2}{\ddot{z}}$ \\
\hline & verall Abundance & $\mathrm{R}$ & $\mathrm{C}$ & $\mathrm{C}$ & $\mathrm{C} \mathrm{C}$ & C $\mathrm{C}$ & A & R \\
\hline & tching $(1,2,3)$ & 1 & 1 & 1 & 11 & 11 & 1 & 1 \\
\hline & vergrowth $(1,2,3)$ & 1 & 1 & 1 & 11 & 11 & 1 & 1 \\
\hline 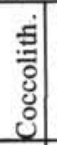 & \begin{tabular}{|l|} 
Coccolithus pelagicus \\
C. miopelagicus \\
Cyclococcolithina leptopora \\
Umbilicosphaera mirabilis \\
\end{tabular} & $\mathrm{R}$ & $\begin{array}{l}\mathrm{R} \\
\mathrm{r} \\
\mathrm{C} \\
\mathrm{R} \\
\end{array}$ & F & $\begin{array}{ll} & \mathrm{F} \\
\mathrm{R} & \mathrm{F} \\
\mathrm{F}\end{array}$ & $\begin{array}{ll}\mathrm{R} & \\
\mathrm{F} & \mathrm{F} \\
\mathrm{R} & \mathrm{R} \\
\end{array}$ & $\begin{array}{l}\mathrm{R} \\
\mathrm{R}\end{array}$ & \\
\hline 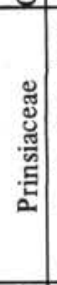 & $\begin{array}{l}\text { Cyclicargolithus floridanus } \\
\text { Emiliania huxleyi } \\
\text { Gephyrocapsa caribbeanica } \\
\text { G. oceanica } \\
\text { Pseudoemiliania lacunosa } \\
\text { Reticulofenestra pseudo- } \\
\text { umbilica } \\
\text { Reticulofenestra sp. }\end{array}$ & \begin{tabular}{l|}
$\mathrm{f}$ \\
$\mathrm{C}$ \\
$\mathrm{F}$ \\
$\mathrm{F}$
\end{tabular} & $\begin{array}{l}\mathrm{r} \\
\mathrm{C} \\
\mathrm{C} \\
\mathrm{r} \\
\mathrm{f}\end{array}$ & $\begin{array}{l}\mathrm{r} \\
\mathrm{A} \\
\mathrm{C} \\
\mathrm{f}\end{array}$ & $\begin{array}{lll} & & \\
C & C \\
C & C\end{array}$ & $\begin{array}{ll} & \mathrm{r} \\
& ? \\
\mathrm{C} & \mathrm{C} \\
\mathrm{C} & \mathrm{C} \\
& \mathrm{R}\end{array}$ & A & $\mathrm{R}$ \\
\hline 2 & Pontosphaera sp. & & $\mathrm{R}$ & $\mathrm{R}$ & $\mathrm{R} \mathrm{R}$ & $\mathrm{RR}$ & $\mathrm{R}$ & \\
\hline$\simeq$ & Rhabdosphaera clavigera & & $\mathrm{F}$ & $\mathrm{R}$ & $\mathrm{F} \mathrm{F}$ & $\mathrm{R} R$ & $\mathrm{~F}$ & \\
\hline$\infty$ & $\begin{array}{l}\text { Syracosphaera histrica } \\
\text { S. pulchra } \\
\end{array}$ & & $\mathrm{F}$ & $\mathrm{F}$ & $\begin{array}{ll}\mathrm{R} & \mathrm{F} \\
\mathrm{R}\end{array}$ & $\mathrm{R}_{\mathrm{R}}$ & $\mathrm{F}$ & \\
\hline 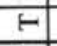 & Thoracosphaera sp. & & $\mathrm{F}$ & $\mathrm{F}$ & $\mathrm{R} \mathrm{F}$ & $\begin{array}{ll}\mathrm{F} & \mathrm{R} \\
\end{array}$ & $\mathrm{F}$ & \\
\hline 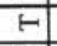 & Triquetrorhabdulus carinatus & & $\mathrm{r}$ & f & & & & \\
\hline 0 & Scapholithus fossilis & & & & $\mathrm{R}$ & $\mathrm{R}$ & $\mathrm{R}$ & \\
\hline 0 & Zygrhablithus bijugatus & & $\mathrm{r}$ & $\mathrm{r}$ & & & & \\
\hline क़्ा & Coronocyclus nitescens & & $\mathrm{r}$ & & & & & \\
\hline 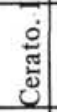 & \begin{tabular}{|l|} 
Ceratolithus cristatus \\
C. rugosus \\
C. telesmus \\
\end{tabular} & $\mathrm{R}$ & \begin{tabular}{|l|}
$\mathrm{C}$ \\
$\mathrm{r}$ \\
$\mathrm{F}$ \\
\end{tabular} & F & $\begin{array}{rr}\mathrm{R} F \\
\mathrm{~F} \\
\mathrm{~F}\end{array}$ & $\begin{array}{ll}\mathrm{R} & \mathrm{R} \\
\mathrm{R} & \mathrm{R} \\
\end{array}$ & r & \\
\hline $\begin{array}{l}.0 \\
\frac{0}{0} \\
\text { I }\end{array}$ & $\begin{array}{l}\text { Helicopontosphaera kamptneri } \\
\text { H. recta } \\
\text { H. sellii } \\
\text { Helicopontosphaera } \text { sp. }\end{array}$ & $\mathrm{C}$ & $\mathrm{C}$ & $\mathrm{F}$ & $\mathrm{FC}$ & C R & $\begin{array}{l}\mathrm{r} \\
\mathrm{r} \\
\mathrm{F}\end{array}$ & \\
\hline 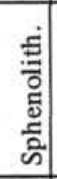 & $\begin{array}{l}\text { Sphenolithus belemnos } \\
\text { S. heteromorphus } \\
\text { S. moriformis } \\
\text { S. neoabies } \\
\text { S. predistentus }\end{array}$ & & $\begin{array}{l}\mathrm{r} \\
\mathrm{f} \\
\mathrm{r}\end{array}$ & $\begin{array}{l}r \\
r \\
f \\
r\end{array}$ & & & & \\
\hline 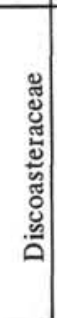 & $\begin{array}{l}\text { Discoaster brouweri } \\
\text { D. challengeri } \\
\text { D. deflandrei } \\
\text { D. druggii } \\
\text { D. exilis } \\
\text { D. pentaradiatus } \\
\text { D. surculus } \\
\text { D. tamalis } \\
\text { D. variabilis }\end{array}$ & & $\begin{array}{ll}\text { r } \\
\text { r } \\
\text { r } \\
\text { r } \\
\text { r } \\
\text { r } \\
\text { r }\end{array}$ & $\begin{array}{l}\text { f } \\
\text { f } \\
\text { r } \\
\text { r }\end{array}$ & & & $r$ & R \\
\hline
\end{tabular}

Note: $\mathrm{R}=$ rare, $\mathrm{F}=$ few, $\mathrm{C}=$ common, $\mathrm{A}=$ abundant. Etching 1-3: increase in etching, overgrowth 1-3: increase in overgrowth of calcareous nannofossils. r, f: rare resp. few reworked specimens. coccoliths and discoasters renders the age assignment of Cores 3 and $1 \mathrm{~A}$ difficult, but a late Pleistocene age seems most likely. The only sample studied from Hole 353B was scratched from a piece of basalt and contained only very few and moderately well-preserved coccoliths of late Oligocene to Miocene and Pleistocene age. Hay (1970) also reports sparse to poor Pleistocene assemblages of calcareous nannofossils from nearby Site 26 in the Vema Fracture Zone.

\section{Site 354-Ceará Rise}

At Site 354, which was drilled at a water depth of 4052 meters, 18 sedimentary cores were recovered before reaching basaltic basement at a subbottom depth of 886 meters. Calcareous nannofossils are common to abundant in most samples studied. Preservation varies considerably down the hole. Extensive solution occurred through most of the middle and upper Miocene above a very short hiatus in the middle Miocene. Below, the calcareous nannofossils are increasingly affected by overgrowth as well. Preservation is poor in the lowermost Maestrichtian cored in Core 18. Table 5 shows the Tertiary coccolith zones recognized at this site and Tables 5 through 8 give the distribution of the calcareous nannofossils in all samples studied.

\section{Pleistocene}

Core 1 contains abundant Emiliania huxleyi and a rich tropical assemblage, where less solution resistant species are lacking. The surface core can thus be assigned to the late Pleistocene to Holocene E. huxleyi Zone (NN21). Core 2 was taken at a subbottom depth of 54 meters and only the core-catcher was retrieved. It contains a rich assemblage including Gephyrocapsa oceanica and Pseudoemiliania lacunosa as well as Emiliania annula and can be assigned to the upper part of the early Pleistocene P. lacunosa Zone (NN19) or the $G$. oceanica Zone of Bukry (1973c). Despite the presence of detrital material, no reworked coccoliths were found.

\section{Pliocene}

Core 3 and the upper part of Section 4-1 belong to the Discoaster surculus Zone (NN16), although rare specimens of small Reticulofenestra pseudoumbilica-like coccoliths occur throughout the interval. Sample 4-1, $120 \mathrm{~cm}$ seems to belong to the early Pliocene Ceratolithus rugosus Zone (NN13). In this sample the first occurrence of $C$. rugosus is noted as well as the last occurrence of Sphenolithus neoabies and S. abies, while in the lowermost sample belonging to NN16 the first occurrence of $P$. lacunosa was found $(4-1,70 \mathrm{~cm})$. It is most likely that a hiatus is present in the $50 \mathrm{~cm}$ between the two samples, a color change being noted at 4-1, 100 $\mathrm{cm}$. It cannot be excluded, however, that the upper part of Section 4-1 was picked up higher up in the interval drilled with the core barrel in place than was the rest of Core 4. From Sample 4-2, $20 \mathrm{~cm}$ on down to the core catcher of Core 4, the A. tricorniculatus Zone (NN12) is represented by an assemblage rich in ceratoliths and discoasters. A special effort was made to illustrate the ceratoliths at this site and especially in Core 4 (Plates 1- 
TABLE 5

Distribution of Calcareous Nannofossils in the Neogene at Site 354

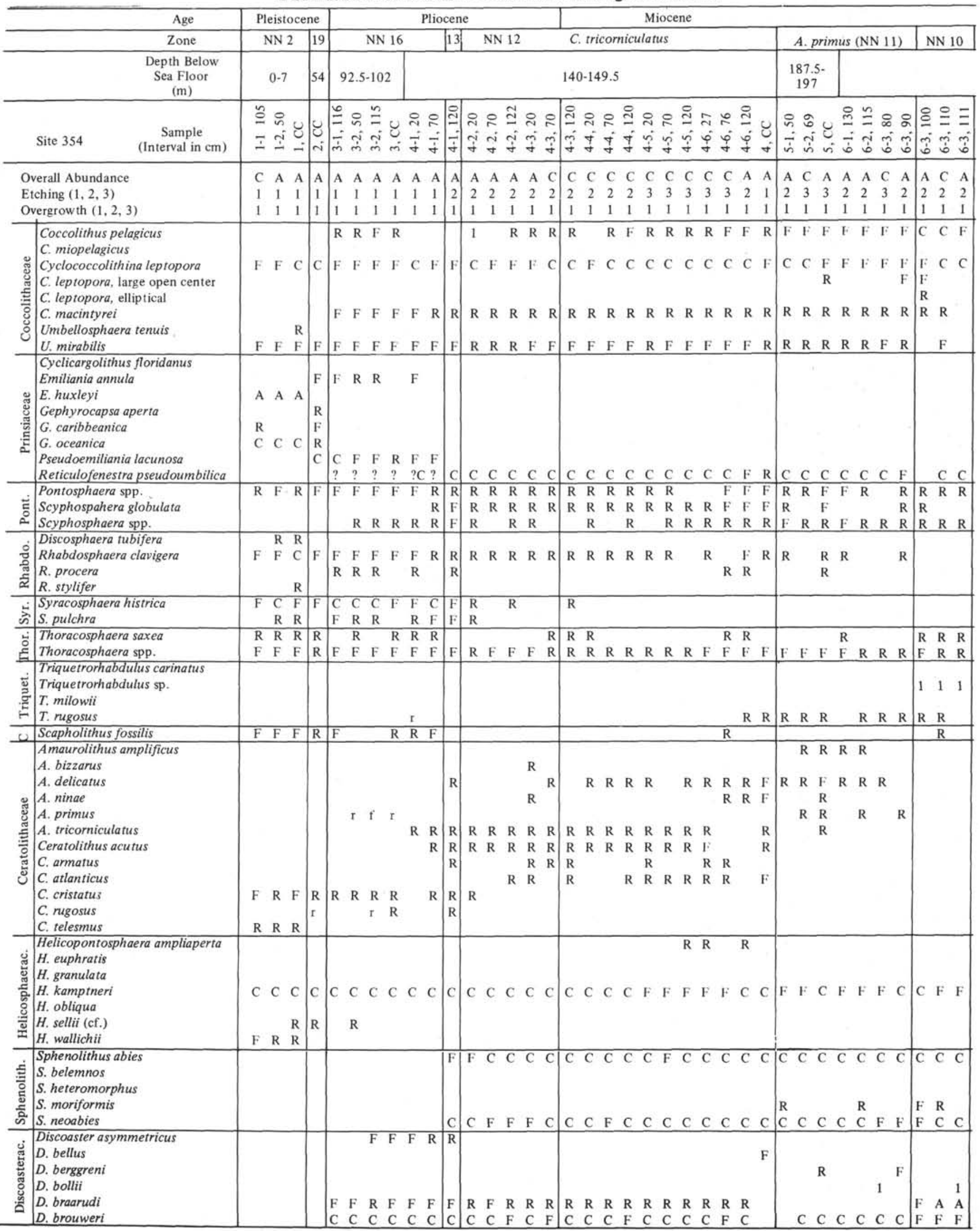


TABLE 5 - Continued

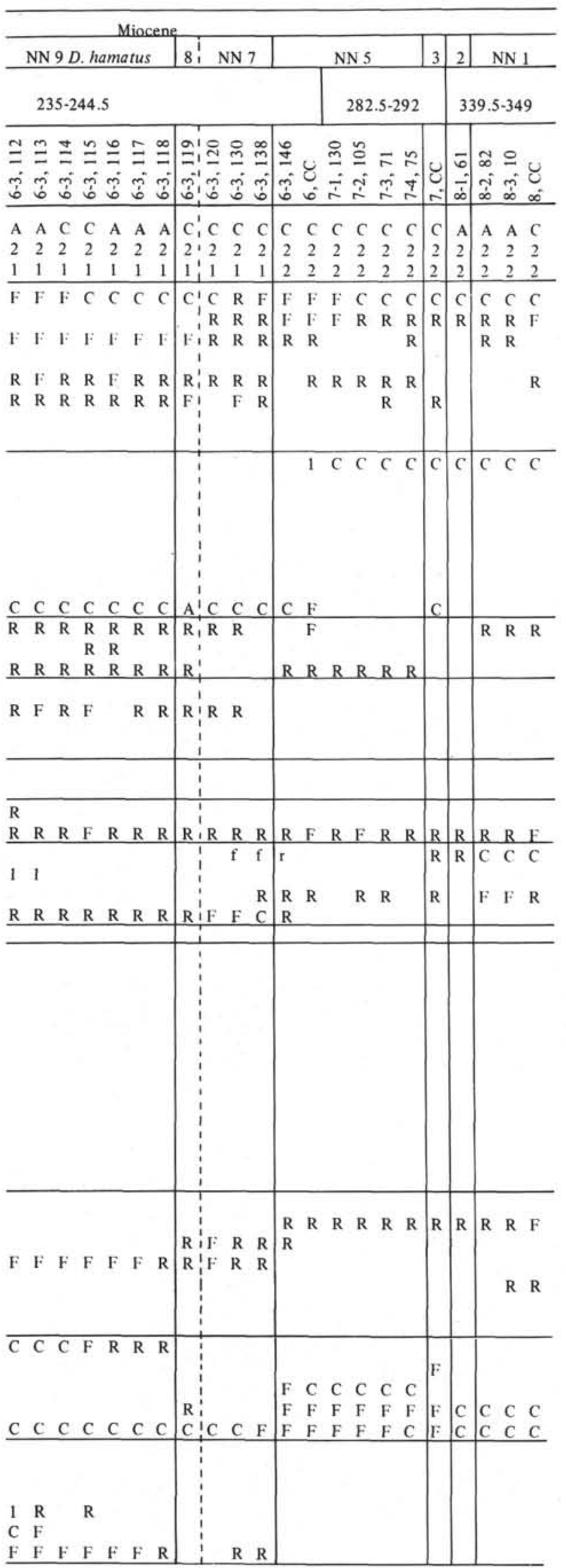

10). In addition to all previously described species of the genera Amaurolithus and Ceratolithus, two new species, $C$. atlanticus and $A$. ninae, were found and are described here.

The Miocene/Pliocene boundary lies within the $A$. tricorniculatus Zone and was set in Section 4-3 by foraminifers. This is in good accordance with the first occurrence of $C$. acutus in this section, this species having been found by Gartner (1973) to have its first occurrence only a few meters above the base of the Pliocene in Sicily.

\section{Miocene}

Core 5 and the upper part of Section 6-3 belong to the upper part of the Discoaster quinqueramus Zone (NN11) or the Amaurolithus primus Subzone of Bukry (1973c). Ceratoliths and discoasters are well represented also in these assemblages, indicating warm conditions when the sediment was deposited. The first $A$. primus and D. quinqueramus, the latter occurring common at once, were found in Sample 6-3,90 cm. Ten $\mathrm{cm}$ below, in Sample 6-3, $100 \mathrm{~cm}$, neither of the two species is present, thus indicating that the lower part of the $D$. quinqueramus Zone is missing at this site. The underlying $D$. calcaris Zone (NN10) only goes down to Sample 6-3, $111 \mathrm{~cm}$, the last occurrence of $D$. hamatus being noted at $6-3,112 \mathrm{~cm}$. The latter sample is the only one in the D. hamatus Zone (NN9) in which Catinaster calyculus and $C$. coalitus do not occur together with $D$. hamatus, the first occurrence of which was observed in Sample 6-3, $118 \mathrm{~cm}$. A single specimen of a questionable $C$. coalitus, the first occurrence of which defines the base of the $C$. coalitus Zone (NN8), was found in Sample 6-3, $119 \mathrm{~cm}$. In Sample 6-3, $120 \mathrm{~cm}$, the last occurrence of Coccolithus miopelagicus, Discoaster deflandrei, D. kugleri, and the first occurrence of D. variabilis were observed. From here on down to Sample $6-3,138 \mathrm{~cm}$, the assemblages are indicative of the D. kugleri Zone (NN7). The D. exilis Zone NN6 is either missing or is present in the unsampled $8-\mathrm{cm}$ interval between the first occurrence of D. kugleri in 6$3,138 \mathrm{~cm}$ and the last occurrence of $S$. heteromorphus at $6-3,146 \mathrm{~cm}$. Between the latter sample and $6-3,146 \mathrm{~cm}$, overgrowth becomes notably more important and the assemblage includes Sphenolithus heteromorphus. The presence of the $S$. heteromorphus Zone (NN5) was observed down to Section 7-4. No Helicopontosphaera ampliaperta was found in this interval, while $D$. exilis is present throughout. The last occurrence of $H$. euphratis was observed as high as the last occurrence of $S$. heteromorphus. If the last occurrences of $H$. euphratis and $H$. ampliaperta coincide, as suggested by $\mathrm{Haq}$ (1973), the interval from $3-6,146 \mathrm{~cm}$ through $7-4,75 \mathrm{~cm}$ could/should be correlated to the $H$. ampliaperta Zone (NN4) rather than to the $S$. heteromorphus Zone (NN5) as suggested here. In this case, a hiatus including NN6 and NN5 is likely between $6-3,138 \mathrm{~cm}$ and $6-3,146 \mathrm{~cm}$. Whether a hiatus includes only NN6 or NN5 too, there is still the possibility that at least Sample 6, CC was picked up in or at the bottom of the interval drilled with the core barrel in place. $S$. belemnos is present in the core-catcher of Core 7 and thus assigns it to the $S$. belemnos Zone (NN3), since only rare Triquetro- 
TABLE 5 - Continued

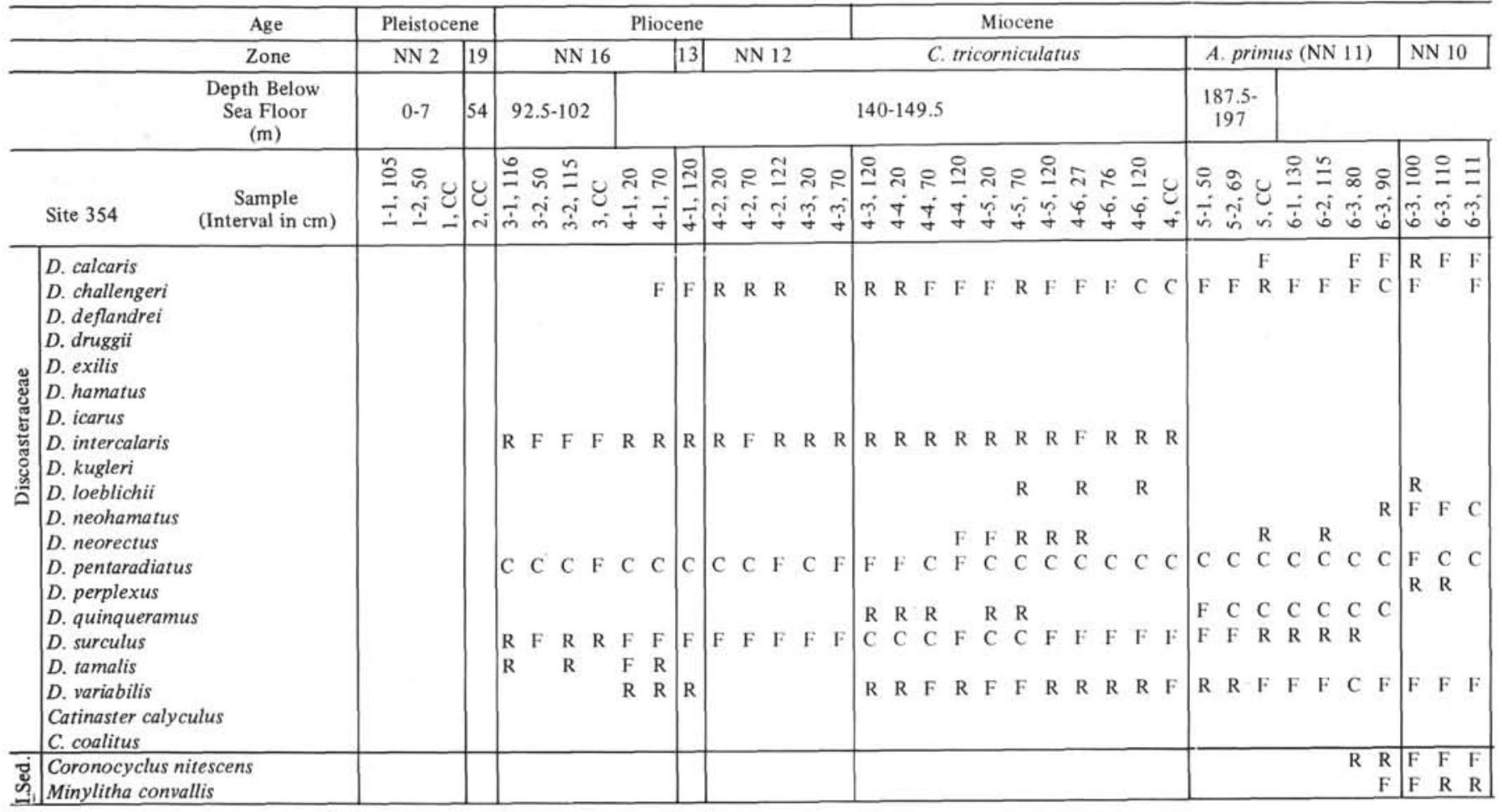

rhabdulus carinatus are present. Rare specimens of $D$. druggi were found in Section 8-1 and the assemblage also only contains rare $T$. carinatus, thus assigning this section to the D. druggi Zone (NN2). Sections 8-2 through 9-5 belong to the $T$. carinatus Zone which spans the Miocene/Oligocene boundary; this boundary was here placed between Sections 9-2 and 9-3 on foraminiferal evidence. $T$. carinatus is common in most samples belonging to the $T$. carinatus Zone.

\section{Oligocene}

The last occurrence of $S$. ciperoensis was used to define the top of the $S$. ciperoensis Zone (NP25), since $H$. recta only occurs sporadically in the section at this site (see also Bukry, 1973c and Martini, 1976). The rest of the Oligocene in Cores 10, 11, and 12 was zoned according to the standard zonation of Martini (1971). The assemblages include common sphenoliths and Helicopontosphaera but contain no Chiasmolithus. Discoasters are common in the upper part of the Oligocene but rare in the lower. A single specimen of Isthmolithus recurvus was found in the Oligocene, another one in the uppermost Eocene.

The Oligocene/Eocene boundary was found in the core-catcher of Core 12. The change in the coccolith assemblages is so abrupt that it is most likely that the sequence is not complete, despite the fact that both the lowermost zone of the Oligocene and the uppermost zone of the Eocene were recognized and there appear no physical signs of a hiatus between the somewhat lighter gray marly nanno chalk of Eocene age and the Oligocene siliceous gray marly nanno chalk.

\section{Eocene}

The presence of the uppermost Eocene $S$. pseudoradians Zone (NP20) is suggested by $D$. barbadiensis, D. saipanensis, a single $I$. recurvus, and rare $S$. pseudoradians in the bottom part of the corecatcher of Core 12 and in Core 13. Small, undescribed chiasmoliths are very rare in NP20 but become somewhat more common in NP15, the Nannotetrina fulgens Zone, which was found in the core catcher of Core 13 and in Core 14. Here the assemblage also contains $C$. grandis, $C$. solitus, and $C$. gigas, the latter assigning the interval to the $C$. gigas Subzone of Bukry $(1973 \mathrm{c})$. Nannotetrina sp. is rare and the only $N$. fulgens found occur (reworked ?) in NP20. !Pseudotriquetrorhabdulus inversus and Zygrhablithus bijugatus occur consistently in NP15 while Pontosphaera and Scyphosphaera species were only found sporadically in the Eocene of this site. Despite the generally poor preservation, the Eocene assemblages are considerably more diverse than the Oligocene ones. The Paleocene/Eocene boundary was not cored.

\section{Paleocene}

The calcareous nannofossils in Core 15 represent the late Paleocene Discoaster multiradiatus Zone (NP9). The assemblage includes only very rare fasciculiths, and a single specimen of Helicopontosphaera cf. $H$. seminulum was found in Sample 15-2, $113 \mathrm{~cm}$. Most of Core 16 also belongs to the D. multiradiatus Zone, but the assemblage here includes common Fasciculithus tympaniformis and some other fasciculiths. A condensed but bioturbated sequence containing the $D$. nobilis (NP8), the D. mohleri (NP7), the $H$. kleinpellii (NP6), and the $F$. tympaniformis (NP5) zones was found in Section 16-6. The preservation of the Paleocene assemblages, especially in Core 16 , is somewhat better than in the Eocene assemblages and the diversity higher, but not as high as in Paleocene assemblages from shelf areas. While the lowermost part 
TABLE 5 - Continued

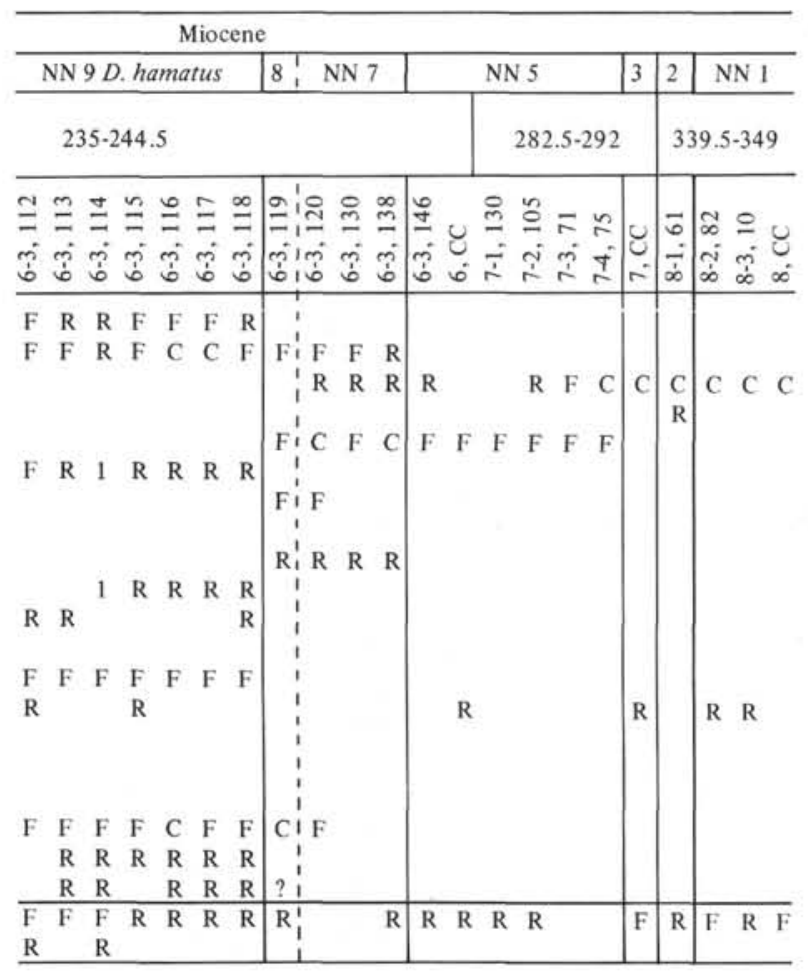

of the core catcher of Core 16 contained a late Maestrichtian assemblage, a piece of gray nanno chalk was found loose on top of Core 17. It included an almost monospecific assemblage of Thoracosphaera operculata, a species which often reaches abundance in the lowermost Paleocene all over the world and which is rock forming in the Danian of northern Europe. This sample can be assigned to the lowermost Tertiary Zone NP1, of Markalius inversus. The Cretaceous/Tertiary boundary was not cored but lies within the 9.5-meter interval between Cores 16 and 17. It seems that the early Tertiary as well as the latest Cretaceous are represented at this site and that it is possible that sediment was deposited-possibly at a slow rate, but fairly continuously-across the Tertiary/Cretaceous boundary.

\section{Late Cretaceous}

Nephrolithus frequens, the marker species for uppermost Maestrichtian in high latitudes, was found in the samples from the bottom of the core catcher of Core 16. Micula mura, the marker species for uppermost Maestrichtian in low latitudes, which was expected to occur at this low latitude site, was not found. Since it usually occurs just above $N$. frequens, where the two species are found together, it might be present in the uncored interval between Cores 16 and 17. Sections 17-1 and 17-2 belong to the Lithraphidites quadratus Zone. While the assemblage of the $N$. frequens Zone in the core-catcher of Core 16 was quite diverse, diversity decreases in the L. quadratus Zone and in the underlying Arkhangelskiella cymbiformis Zone, in which the oldest sediments recovered belong
(Core 18). Since Tetralithus trifidus, the marker species of the late Campanian/early Maestrichtian in low latitudes, was not found here, it can be assumed that the age of the oldest sediment cored at this site is early, but not earliest, Maestrichtian. A. cymbiformis is only rare below the core catcher of Core 17, Kamptnerius magnificus, a species usually preferring shelf-depths, consistently shows higher abundance (few) than $A$. cymbiformis. Generally coccoliths are common but poorly preserved, having suffered from solution as well as overgrowth.

\section{Site 355-Brazil Basin}

Site 355 in the Brazil Basin was drilled at a depth of 4901 meters to date magnetic anomaly 33 and to detail the sedimentary history at this deep site. Twenty sedimentary cores were recovered before reaching basaltic basement at a subbottom depth of 443 meters in Core 21. Calcareous nannofossils are absent or very rare and not age diagnostic in Core 1. The late Miocene and the early Miocene assemblages recovered from Core 2 most probably represent material redeposited by turbidity currents. Core 3 also contains early Miocene assemblages of redeposited calcareous nannofossils. The next core containing coccoliths is Core 17 at a subbottom depth of 405 meters, where the presence of Tetralithus trifidus assigns an early Maestrichtian to late Campanian age to the cessation of calcareous deposition. The oldest assemblage belongs to the early Campanian B. parca Zone as defined earlier in this chapter or to the Eiffellithus eximius Zone as defined by Bukry (1974) between the first occurrence of $B$. parca and the last occurrence of E. eximius. It was found in pieces of sediment among the basalt pieces in the corecatcher of Core 22.

Table 3 shows the Tertiary coccolith zones recognized at this site, and Tables 9 and 10 give the distribution of the calcareous nannofossils in all samples studied.

\section{Pleistocene-Pliocene}

Core 1 consists of silty clay/mud, usually brownish and barren of coccoliths except for single specimens of Gephyrocapsa sp. and rare Sphenolithus neoabies.

\section{Miocene}

Rich and well-preserved assemblages of calcareous nannofossils were found in the highly deformed Core 2 . In Section 1 and the upper part of Section 2, the assemblage includes Discoaster quinqueramus and Amaurolithus delicatus and thus belongs to the upper part of the $D$. quinqueramus Zone (NN11) or the Amaurolithus primus Subzone of Bukry (1973c). In the lower part of Section 2 and the rest of Core 2, rare to common Sphenolithus heteromorphus were found together with Discoaster exilis thus assigning this part of the core to the $S$. heteromorphus Zone (NN5). The hiatus between NN11 and NN5 in Section 2-2 was also observed as a hiatus between N8/9 and N16 of the foraminiferal zonation. Since Site 355 must be considered to have been below the CCD during the whole Cenozoic, the calcareous microfossil 
TABLE 6

Distribution of the Calcareous Nannofossils in the Oligocene and Eocene at Site 354

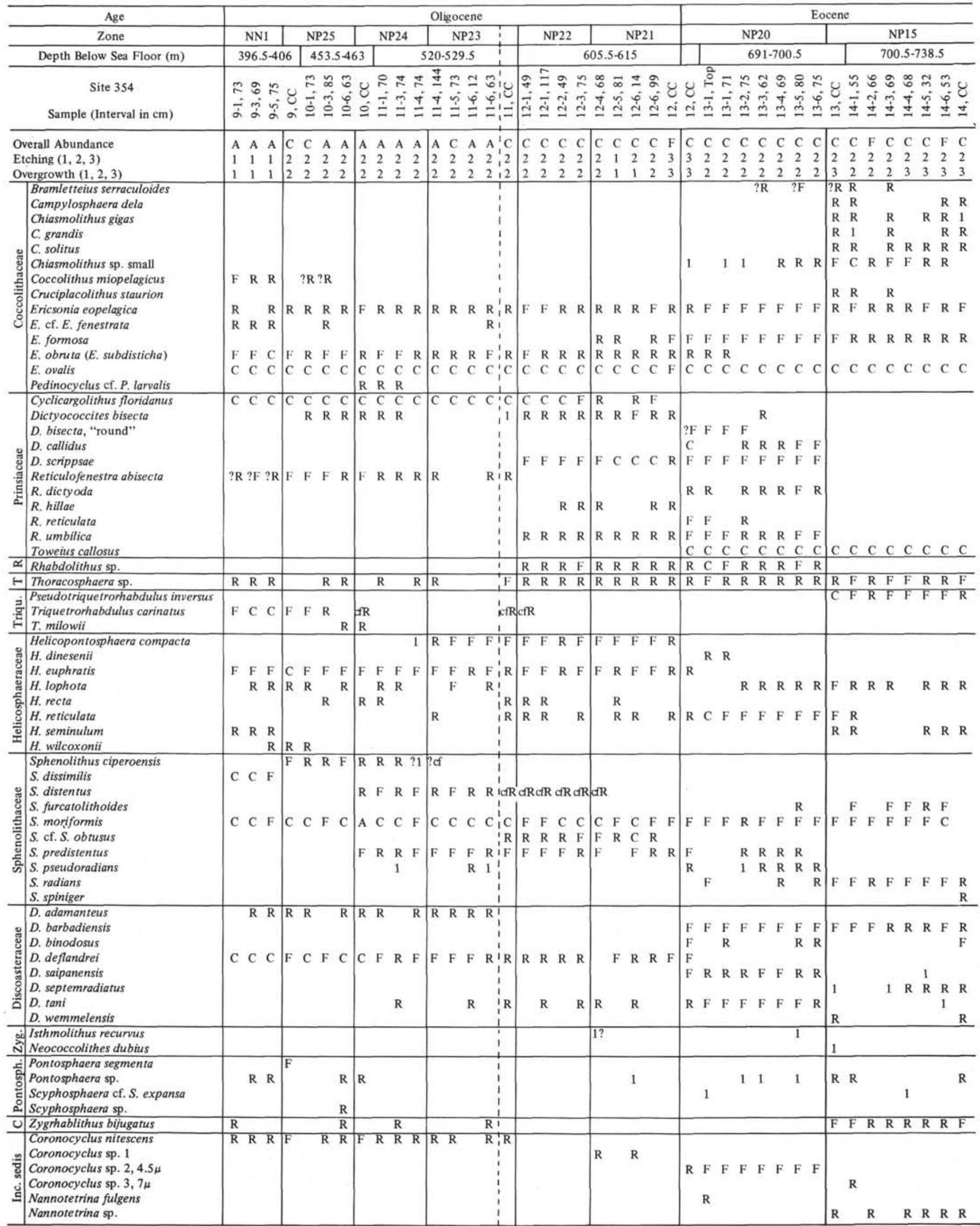


TABLE 7

Distribution of Calcareous Nannofossils in the Paleocene at Site 354

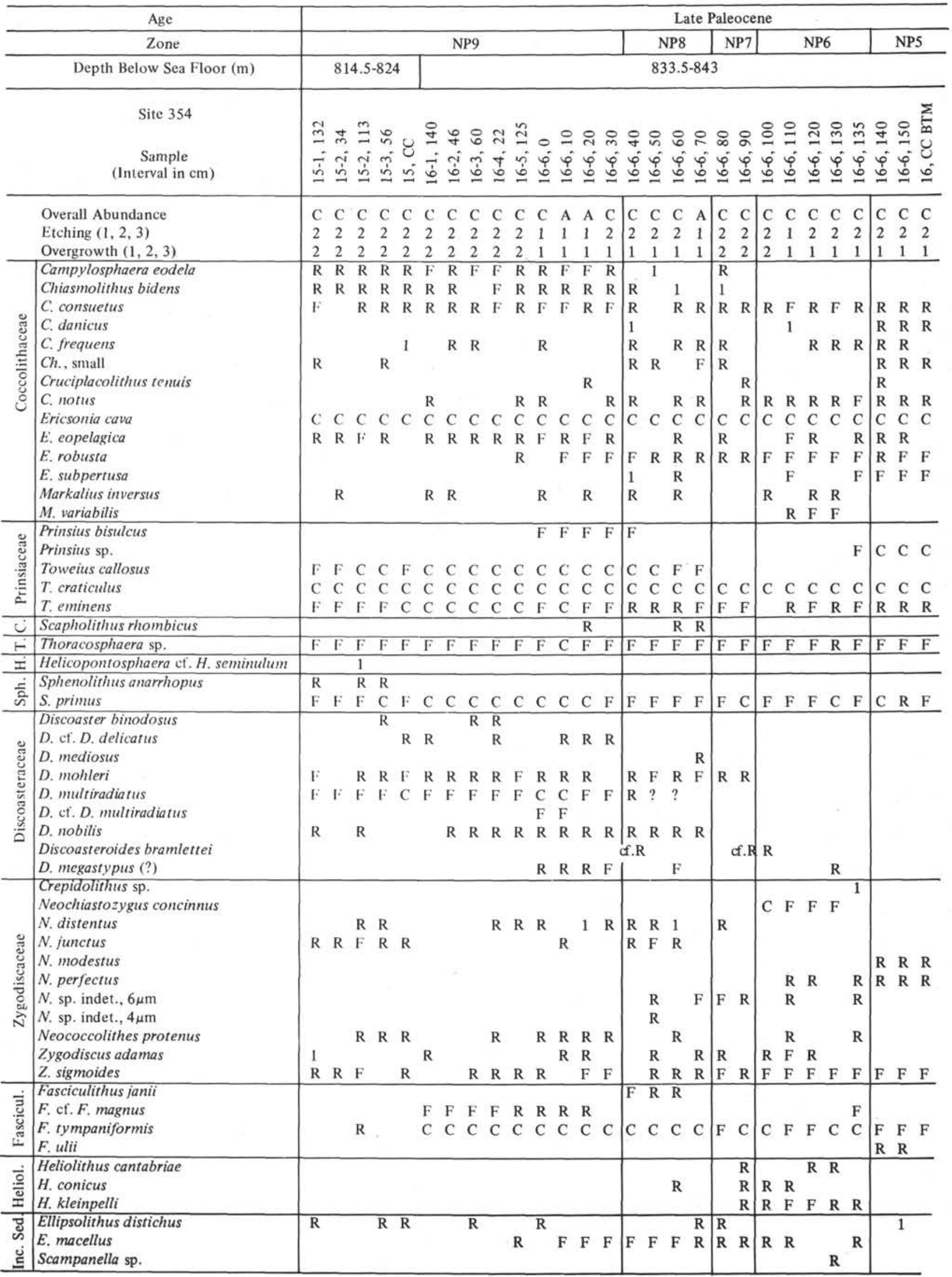


TABLE 8

Distribution of Calcareous Nannofossils in the Maestrichtian at Site 354

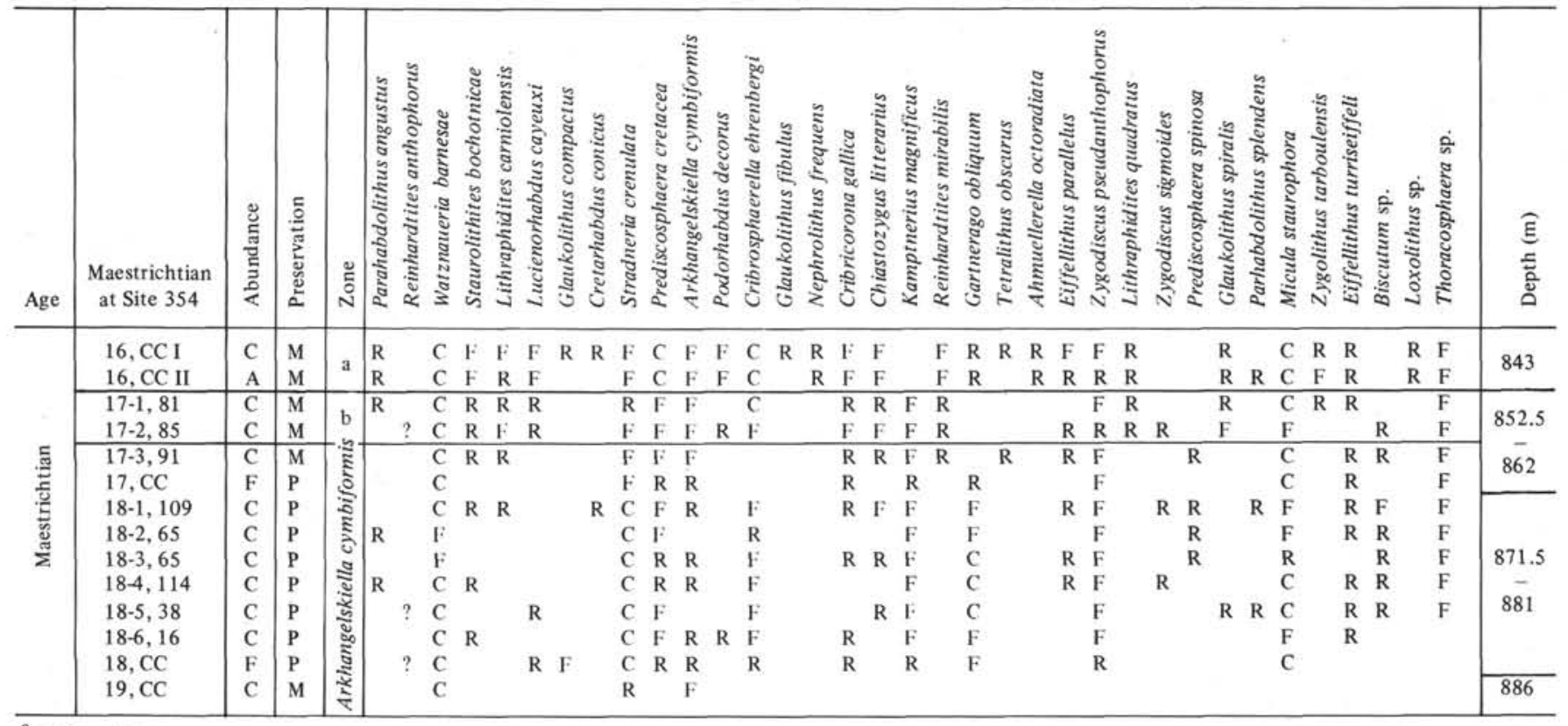

${ }^{\mathrm{a}} N$. frequens

${ }^{\mathrm{b}}$ L. quadratus

assemblages found in Cores 2 and 3 are thought to be redeposited by turbidity currents, evidence for which is found in the lithology as well as in the microfossil assemblages. The coccolith assemblages in Sections 3-1 and 3-2 include $S$. belemnos and $D$. druggi and few $T$. carinatus. They were assigned to the $D$. druggi Zone (NN2). Section 3 belongs to the $T$. carinatus Zone (NN1). No coccoliths were found in Sections 4 and 5 consisting of zeolitic pelagic clays which, however contained planktonic foraminifers of the $G$. angulisuturalis-G. primordius zones (P22-N4). Braarudosphaera sp. and Micrantholithus sp. are consistently present in low numbers in Core 2 and Core 3. These forms that are not normally found in open ocean sediments, further suggest the turbidite origin of the assemblages although only very rare reworked older coccoliths were found.

\section{Late Cretaceous}

Solution-resistant species dominate the Late Cretaceous coccolith assemblages in Cores 17 through 22 . Diversity is low and the assemblages are dominated by $W$. barnesae, $S$. crenulata, and $M$. staurophora. $A$. cymbiformis is rare and $K$. magnificus lacking although these species are relatively solution resistant, and were found to be relatively common in the somewhat younger chalk on Ceará Rise (Site 354).

The youngest coccolith assemblage in Section 17-2 belongs to the $T$. trifidus Zone which spans the Maestrichtian/Campanian boundary, and extends down to Section 19-1. The next two sections include the $T$. gothicus Zone of middle Campanian age and, from the core-catcher of Core 19 on down to the lowermost sediment above basalt, in Section 21-1, the presence of rare $T$. aculeus assigns the interval to the zone of this name. An indurated chalk sample attached to the basalt in the core-catcher of Core 22 yielded an impoverished assemblage of the early Campanian $B$. parca Zone as defined earlier in this chapter.

\section{Site 356-São Paulo Plateau}

Site 356 was drilled in 3175 meters water depth to sample sediments of ages equal to and older than the aresumed Aptian salts. Forty-four sediment cores were recovered before the site was abandoned in upper Albian limestones, at a subbottom depth of 741 meters. Calcareous nannofossils are common to abundant down to the Coniacian/Santonian and rare to common below. Preservation varies considerably, generally deteriorating down the hole. An exception are the relatively well preserved Paleocene assemblages, which are better preserved than the overlying Eocene ones. Preservation is poor from the Coniacian/Santonian on downwards. Tables 1 and 3 show the coccolith zones recognized at this site and Tables 11 through 15 give the distribution of the calcareous nannofossils in all samples studied.

\section{Pleistocene}

A subtropical coccolith assemblage belonging to the E. huxleyi Zone was found in the only sample of Core 1, Sample 1, CC. Common species are E. huxleyi, small Gephyrocapsa sp., and Rhabdosphaera clavigera. Reworked Pliocene forms are rare.

\section{Pliocene}

The late Pliocene $D$. pentaradiatus and $D$. surculus zones are represented in Core 2. Rare to few $\boldsymbol{R}$. pseudoumbilica, which would indicate an early rather than late Pliocene age for this core, are considered to be reworked, as are rare $Z$. bijugatus. The assemblages are subtropical including also U. mirabilis and $S$. fossilis, which were not found in the underlying early Miocene assemblages. Samples 2-1, $70 \mathrm{~cm}$ and $2-1,100 \mathrm{~cm}$ 
TABLE 9

Distribution of Calcareous Nannofossils in the Neogene at Site 355

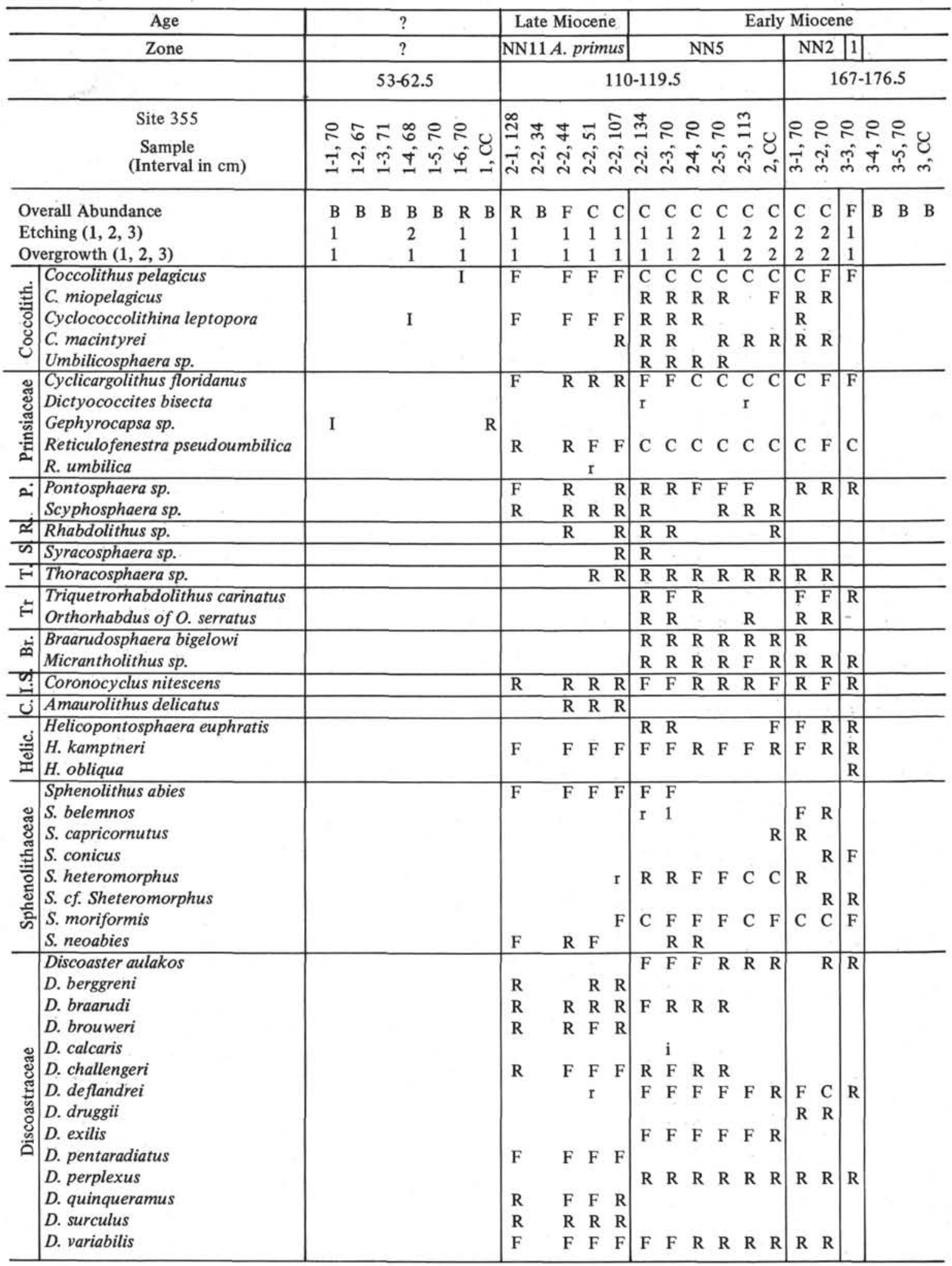


TABLE 10

Distribution of Calcareous Nannofossils in the Campanian and Maestrichtian at Site 355

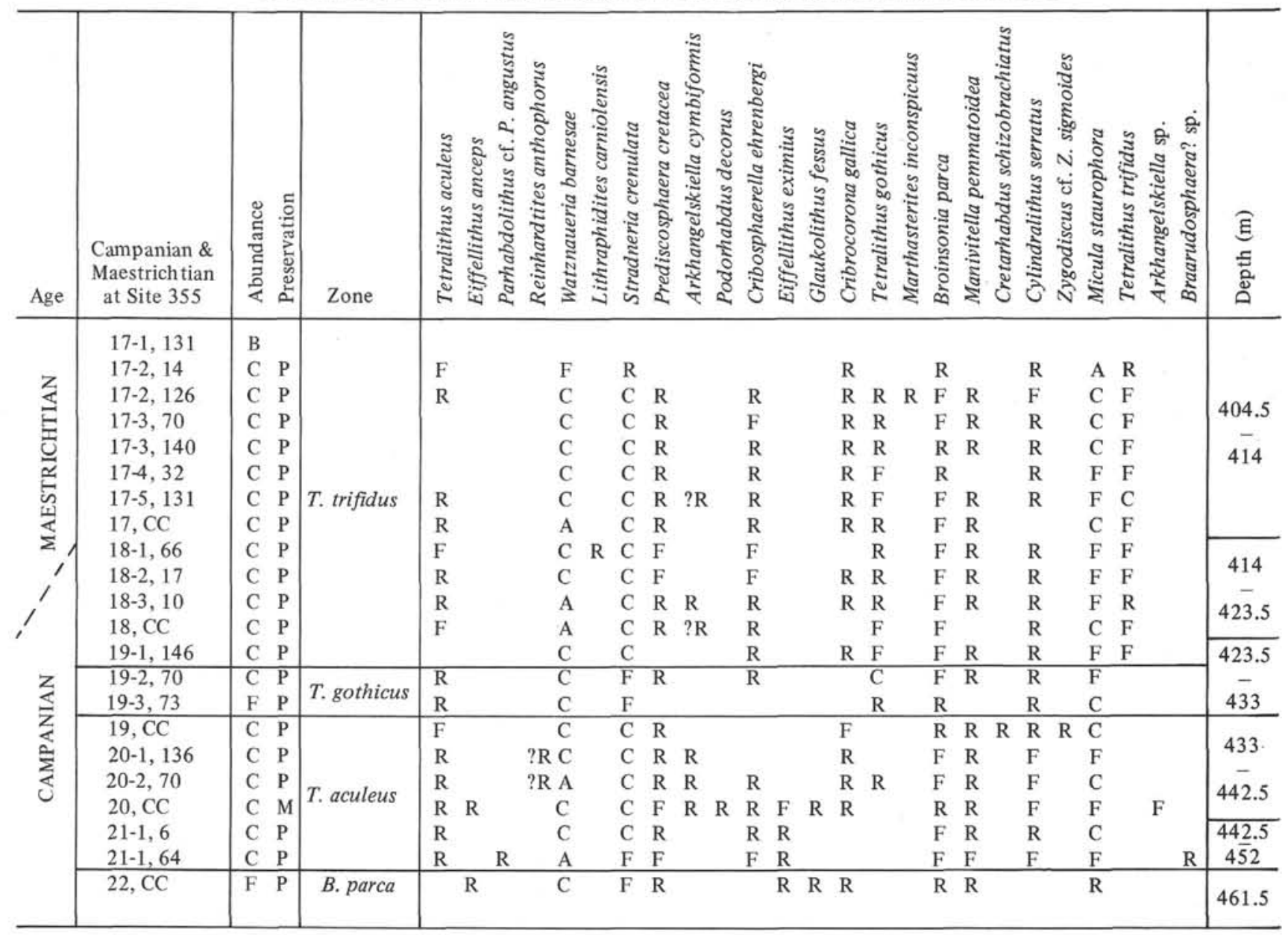

contain zeolitic oozes of slumps of early Eocene age (NP13), in a similar facies to that in which they were later found in Core 12.

\section{Miocene}

Cores 3 through 5 and the upper part of Section 6-1 are early Miocene in age and the relatively poorly preserved coccolith assemblages belong to the $D$. druggii (NN2) and $T$. carinatus (NN1) zones. While $T$. carinatus is especially well developed-specimens up to 60 microns in length are not rare-in Cores 6 and 5, T. milowii occurs consistently in Cores 5 and 4 , and the new species, $T$. challengeri is restricted to Core 4 . Common to abundant species are $R$. pseudoumbilica, $C$. pelagicus, which was rare in the Pliocene and Pleistocene of this site, $S$. moriformis, and $D$. deflandrei. Pontosphaera sp. is consistently present, as are $C$. nitescens, E. tasmaniae, Thoracosphaera sp., and $H$. euphratis. Less consistent but still present in many samples are $R$. abisecta, various Helicopontosphaera, Ilselithina fusa, and C. leptopora. The common occurrence of discoasters, namely $D$. deflandrei, in all Miocene samples indicates a subtropical climate at this site during the early Miocene. On the other hand, the presence of E. tasmaniae and I. fusa, both of which also occur in high latitude lower Miocene sediments of the Indian Ocean (Edwards and Perch-Nielsen, 1975) and are not reported from low latitudes, might indicate increased interaction between the two areas.

In Section 6-1, a hiatus was cored. It includes the lowermost Miocene, the whole Oligocene, and the uppermost Eocene.

\section{Eocene}

Middle Eocene assemblages were recovered in Cores 6 through 10, while Core 11 through the upper part of Section 16-2 are of early Eocene age. The middle Eocene assemblages are especially diverse, although the estimated Discoaster/Chiasmolithus ratio is very low, thus indicating cooler conditions than in the early Eocene, where it is higher. The lower diversity in the lower Eocene is probably due to the poor state of preservation. While Braarudosphaera sp. and Micrantholithus sp. are rare in a few samples, representatives of the genera Pontosphaera, Transversopontis, and Lophodolithus occur consistently, rare to few. Together with the presence of few to common $Z$. bijugatus, which is usually only preserved in samples from shelf depths to about 1000 meters, below which it dissolves (Edwards, personal 
TABLE 11

Distribution of Calcareous Nannofossils in the Neogene at Site 356

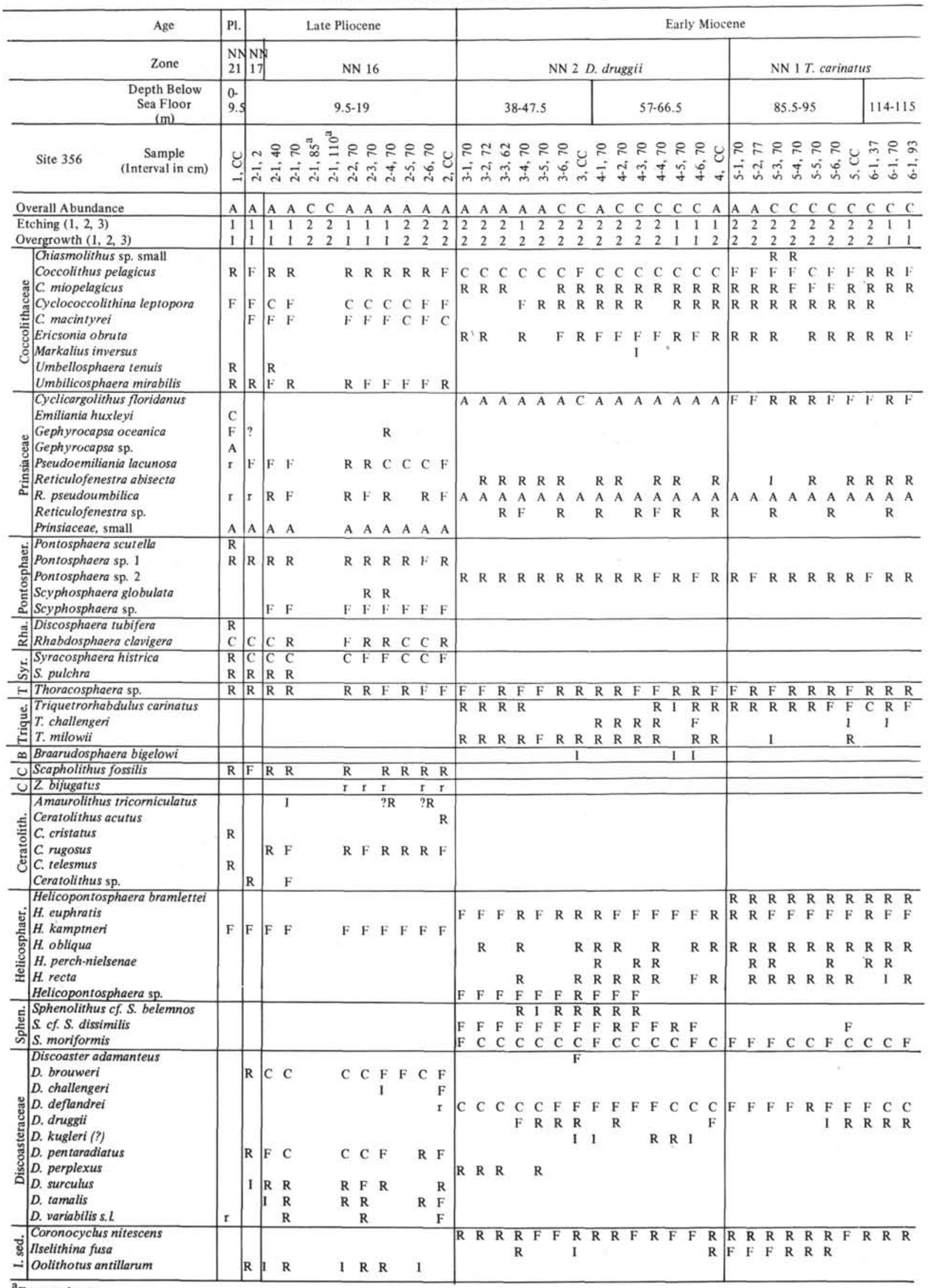

${ }^{\mathrm{a}}$ Eocene slump. 
TABLE 12

Distribution of Calcareous Nannofossils in the Eocene at Site 356

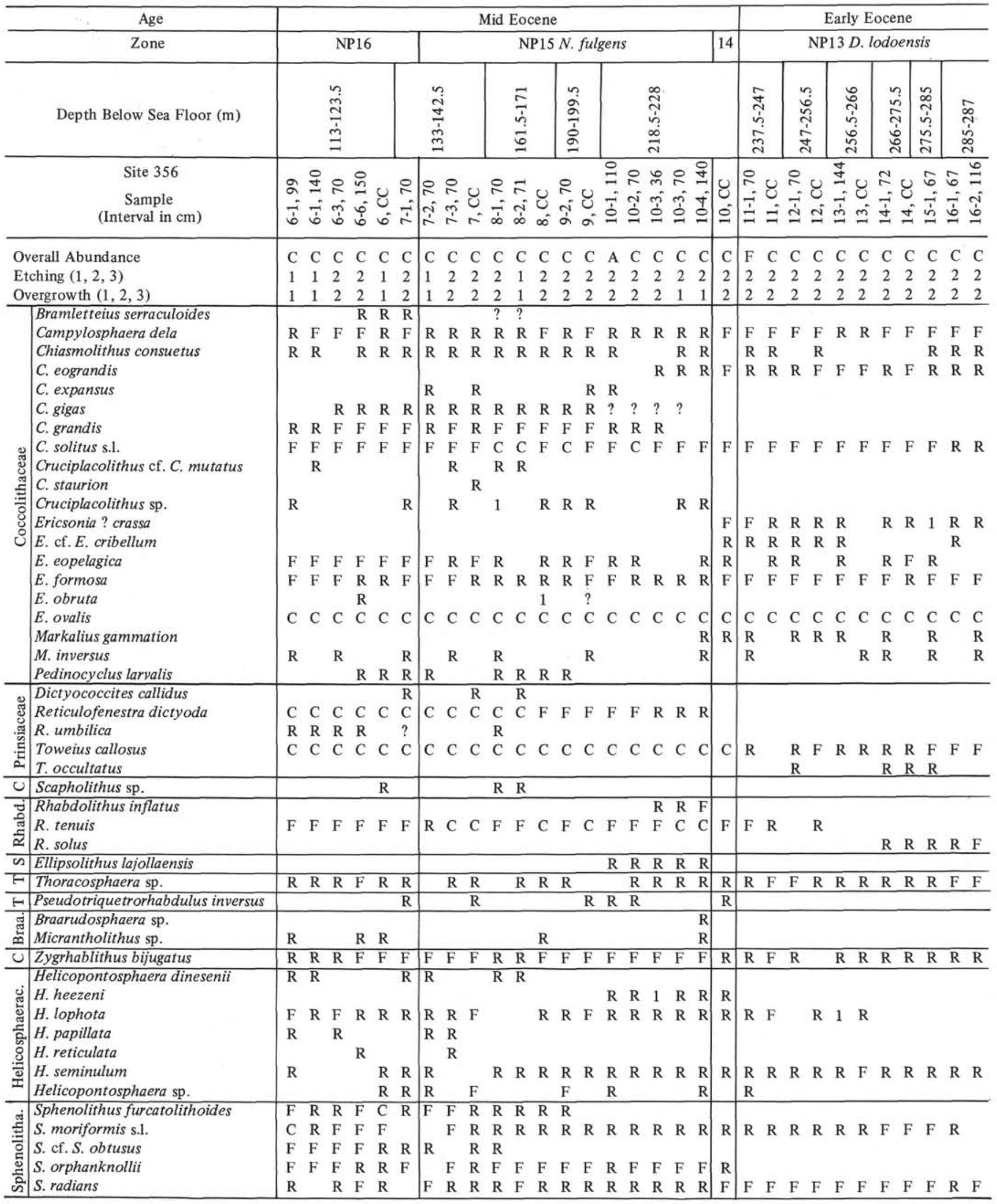


TABLE 12 - Continued

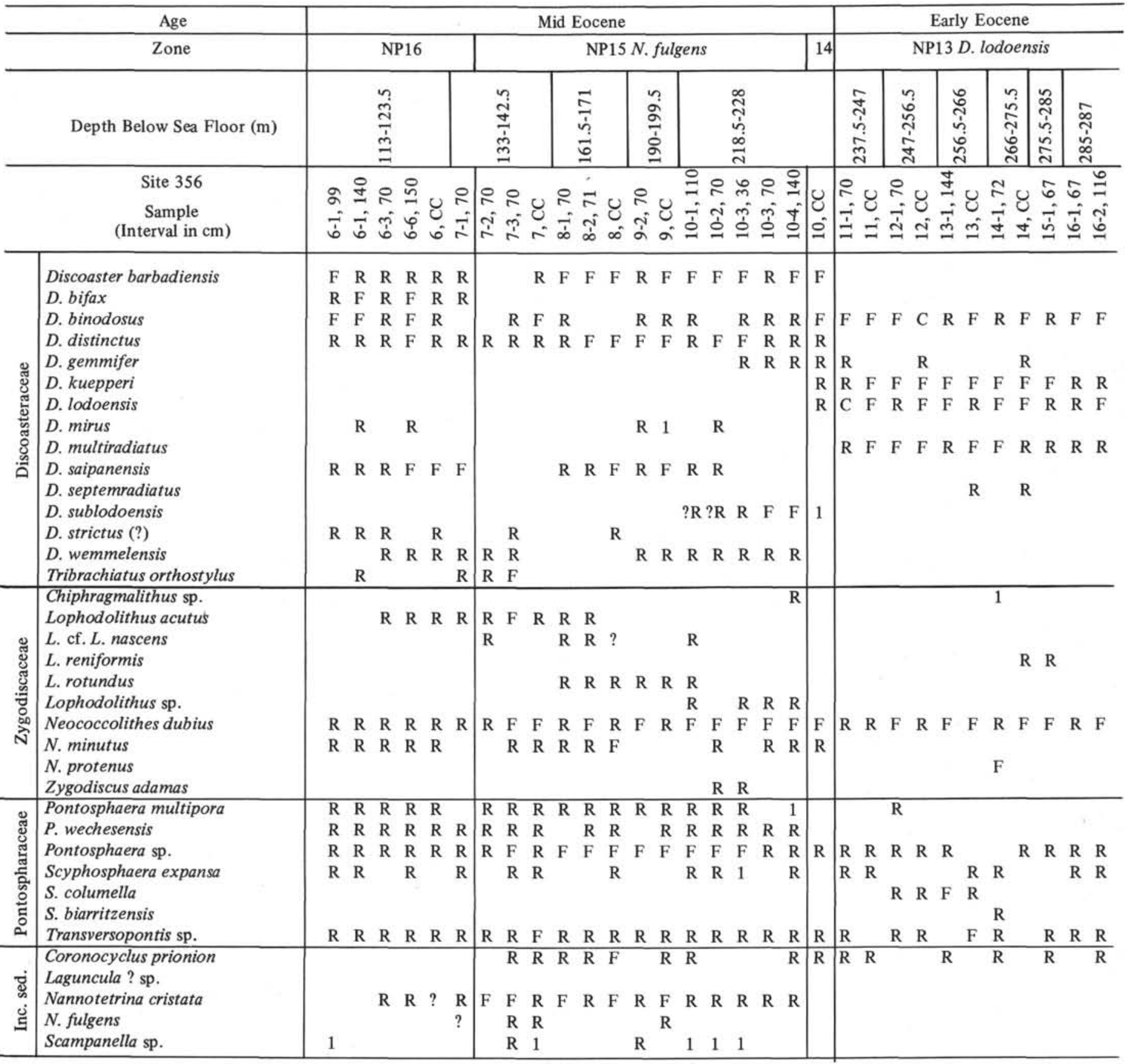

communication), they suggest relatively shallow depth of deposition under nonrestricted conditions.

The youngest Eocene present can be assigned to the D. bifax Subzone of Bukry (1973c) which can be correlated to the lower part of the D. tani Zone (NP16) of Martini (1971). It extends down to Section 7-1. From Sections 7-2 through 10-4, the coccolith assemblages are assigned to the $N$. fulgens Zone (N15). The $R$. inflata Subzone of Bukry (1973c) can be distinguished in Sections 10-3 and 10-4 and thus here correlates with the lower part of the $N$. fulgens Zone and not with the upper part of the D. sublodoensis Zone. The D. kuepperi
Subzone of Bukry (1973c), which is correlated with the lower part of the D. sublodoensis Zone (NP14), was found in the core catcher of Core 10. D. lodoensis is present in all samples down to Section 16-2, while $T$. orthostylus was not found in this interval, but rare specimens occur in the middle Eocene. This supports observations by Bukry (1973c), who found $T$. orthostylus in the $N$. fulgens Zone of California, and renders questionable the boundary between NP12 and NP13, which was taken as the last occurrence of this species. Since Ericsonia ? crassa, the first occurrence of which was suggested by Bukry (1973c) to define the 
TABLE 13

Distribution of Calcareous Nannofossils in the Paleocene at Site 356

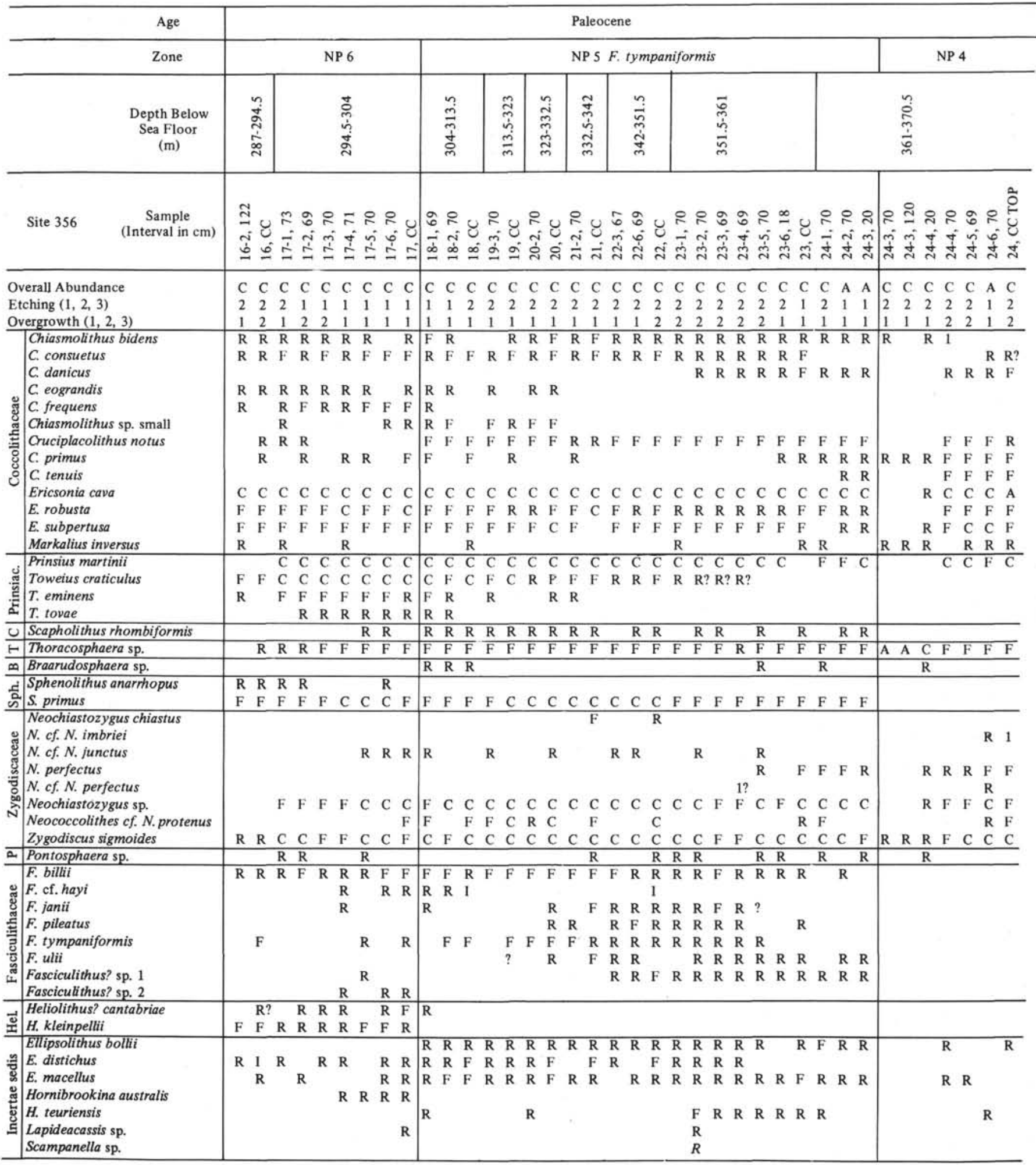

base of the $D$. lodoensis Zone, is present throughout the early Eocene interval at this site, it can be assigned to the $D$. lodoensis Zone.

Of special interest in this Eocene sequence is the presence of "Scyphosphaera expansa" and two other forms of "Scyphosphaera." From the SEM pictures Plate 41 , Figures 13 and 14 , it seems possible that " $S$." expansa should be transferred to the family of the Rhabdosphaeraceae. However, better specimens containing a complete base are necessary to this. If the 
TABLE 14

Distribution of Calcareous Nannofossils in the Basal Paleocene at Site 356

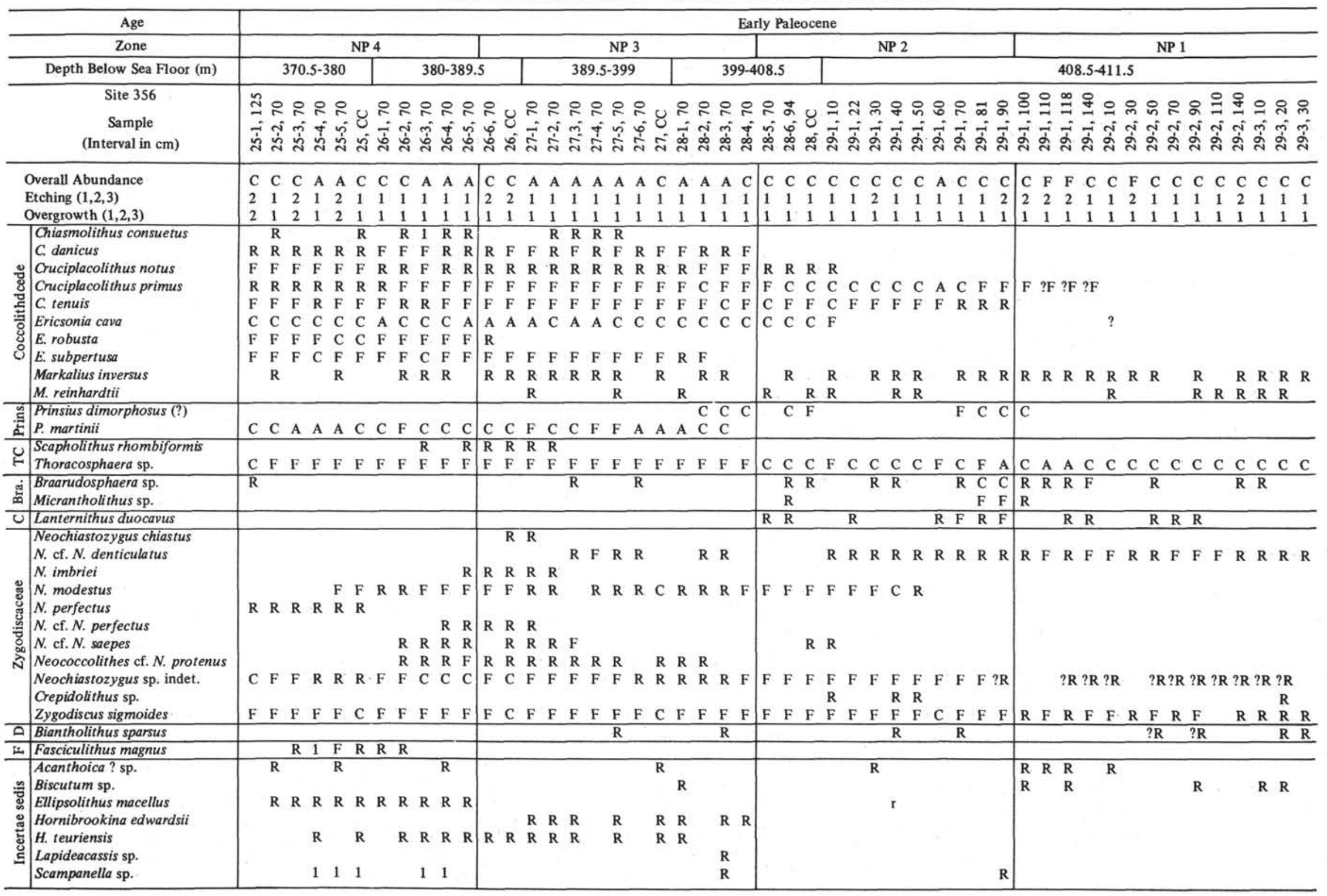


TABLE 15

Distribution of Albian to Maestrichtian Calcareous Nannofossils at Site 356

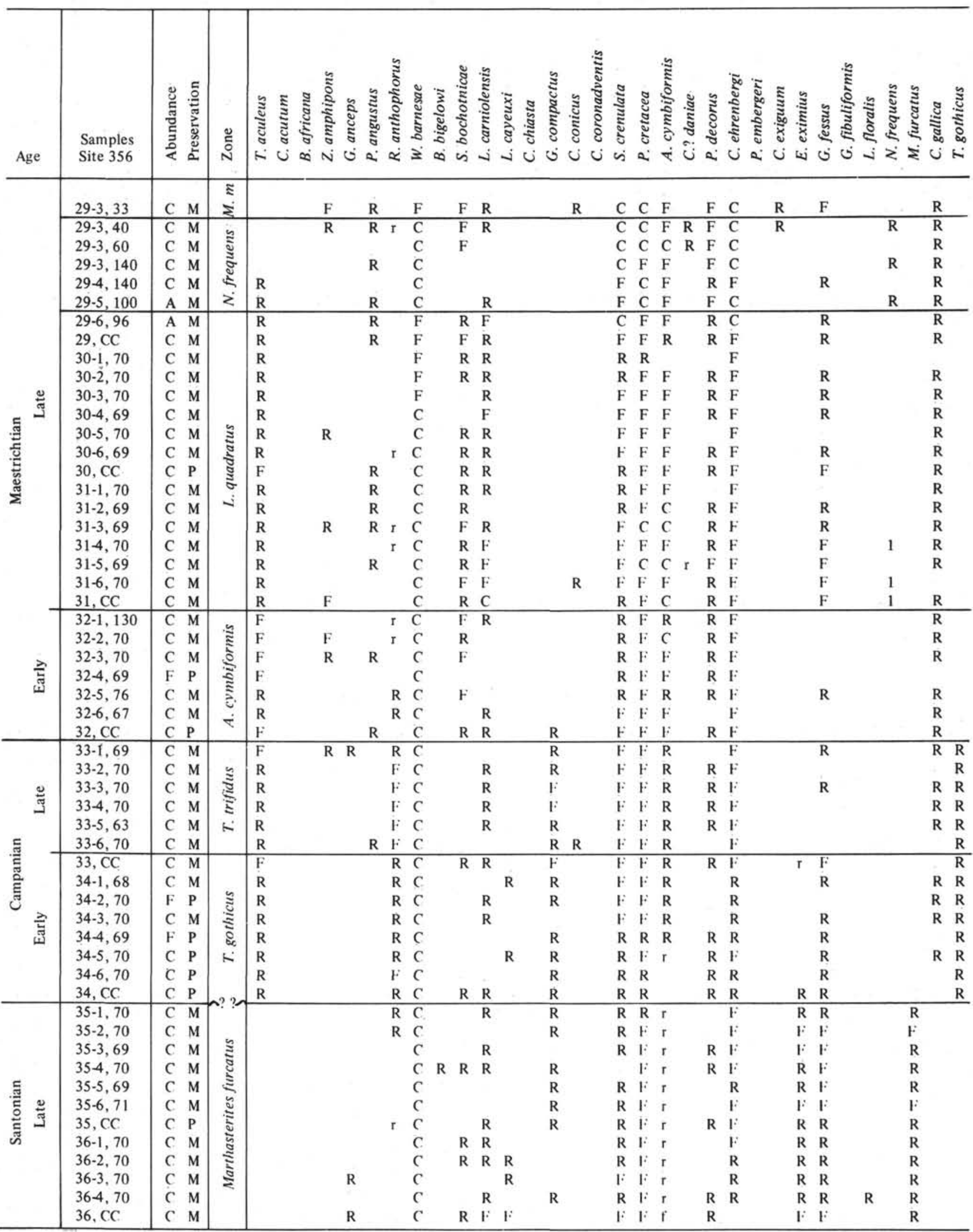


TABLE 15 - Continued

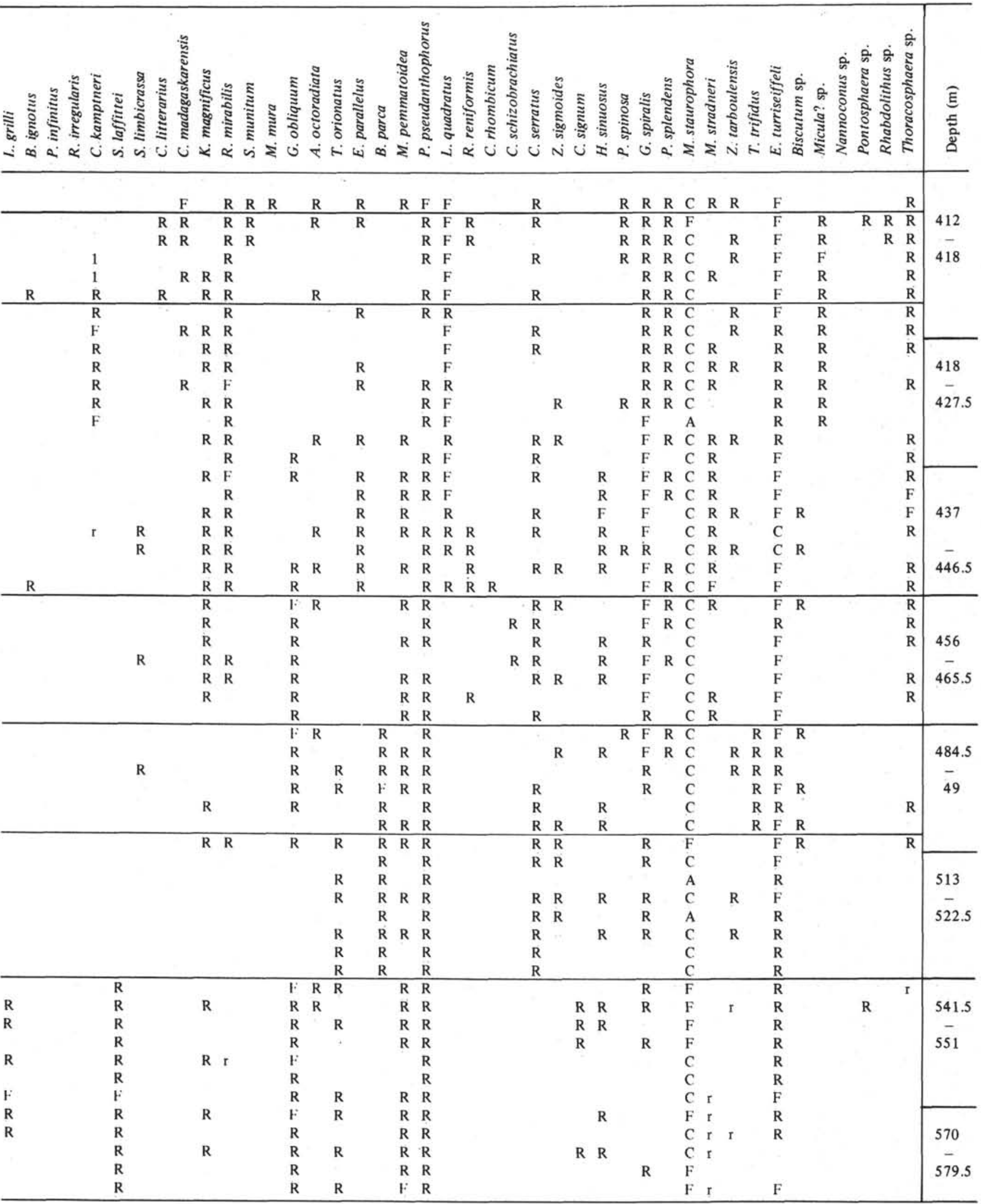




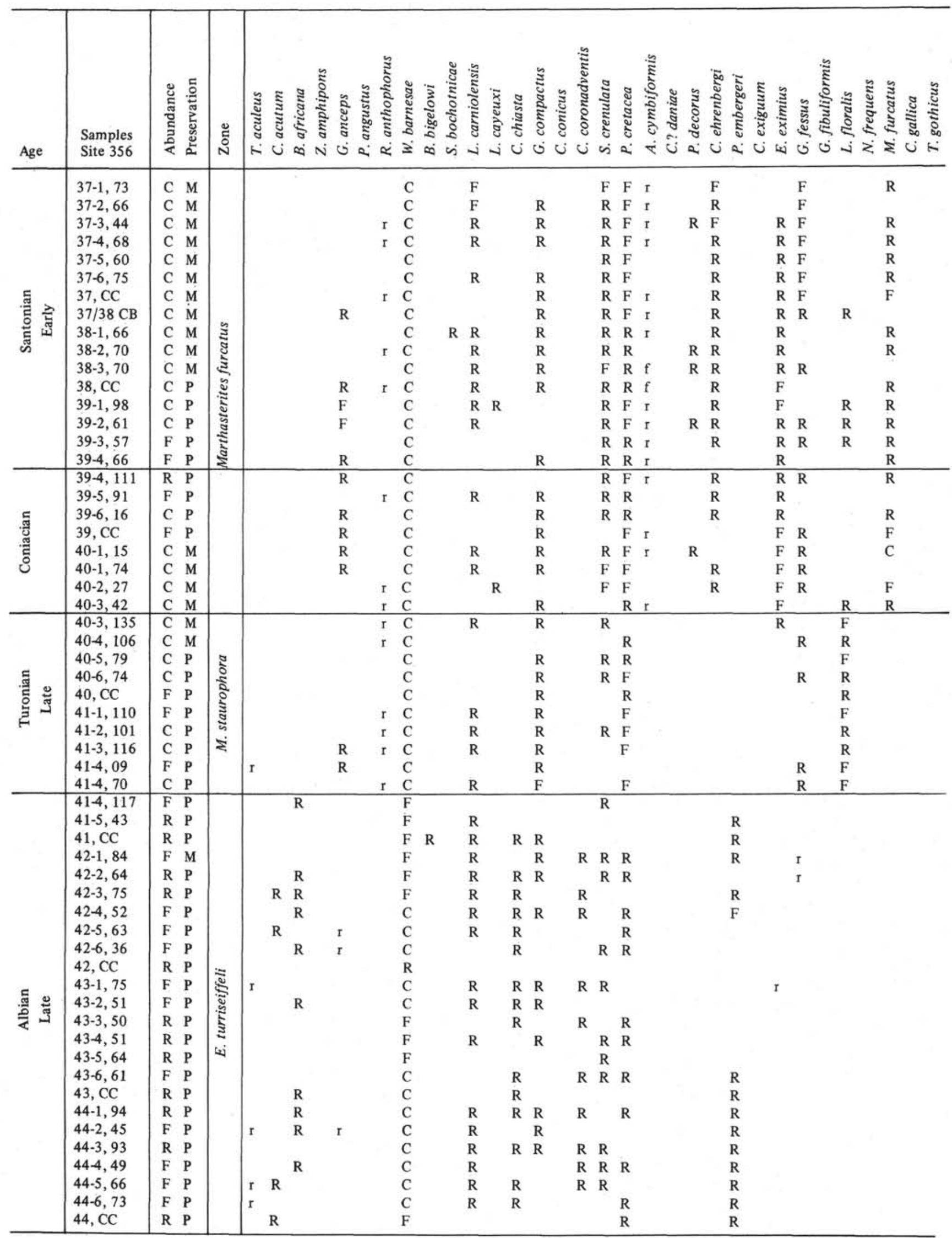


TABLE 15 - Continued

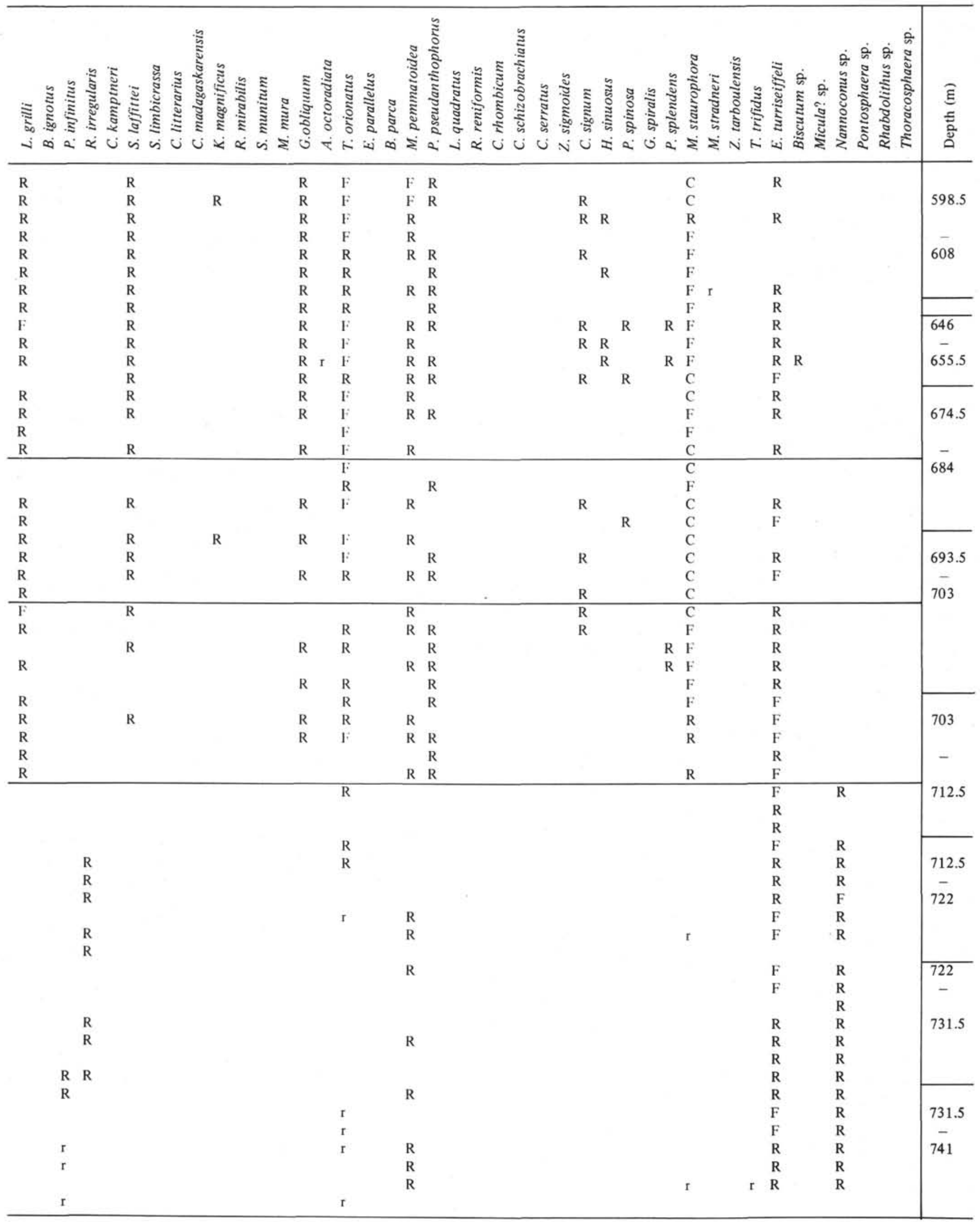


"Scyphosphaera" of the Eocene are, indeed, rhabdoliths, we would no longer need to try to explain the lack of "Scyphosphaera" in the upper Eocene and most of the Oligocene they really begin to develop and diversify in the middle Miocene (Rade, 1975).

The genus Lophodolithus also would be worth some special attention in this section, where most of the presently described species of this genus occur.

\section{Paleocene}

A hiatus was cored in Section 16-2 and includes at least NP12 to NP7, the earliest Eocene and latest Paleocene. In Cores 16 through 29, which were cored continuously with a relatively high recovery, an extraordinarily thick and nearly continuous Paleocene sequence was found. The Cretaceous/Tertiary boundary occurs at Sample 29-3, $33 \mathrm{~cm}$. The preservation of the coccolith assemblages is better than in the overlying lower Eocene sequence. Diversity decreases towards the bottom of the Tertiary sequence due to fewer species having evolved.

The H. kleinpellii Zone (NP6) is represented in Cores 16 and 17. Common coccoliths in these cores are $E$. cava, $P$. martinii, $T$. craticulus, $S$. primus, and $Z$. sigmoides. Less common but still consistently present are E. robusta and E. subpertusa, Thoracosphaera sp., Neochiastozygus sp., and various fasciculiths. Hornibrookina australis was found in the lowermost samples of this zone. No pentaliths were observed and only very rare Pontosphaera sp. occur.

More or less the same species and species abundances were observed in Cores 18 through 24, where, in Section 24-3, the first small fasciculith occurs. This sequence was assigned to the $F$. tympaniformis Zone (NP5), although the first small fasciculith is not $F$. tympaniformis and large fasciculiths, namely $F$. magnus, already occur in Sections 25-3 through 26-2. Hornibrookina teuriensis occurs sporadically in this interval and Heliolithus cantabriae has its first occurrence in the uppermost sample of the $F$. tympaniformis Zone. The first occurrence of the small fasciculiths in Section 24-3 coincides with the first occurrence of the first sphenolith, $S$. primus.

The E. macellus Zone (NP4) was found from Section 24-4 through Section 26-5, where the first $E$. macellus was observed. Diversity in this zone is considerably lower than in NP5 and NP6 at this site, mainly due to the absence of the later evolving fasciculiths, of Toweius and chiasmoliths. The genus Neochiastozygus in this interval is of special interest. Two species of this genus have short ranges around the boundary between NP4 and NP3: $N$. imbriei and $N$. saepes. The presence of the latter here allows the correlation of this sequence with the type Danian, where $N$. saepes occurs only in the uppermost Danian, which is usually assigned to NP3, since the marker fossil of NP4, E. macellus, is missing. The presence of $N$. imbriei was also noted at Site 357 around the NP4/NP3 boundary and might be used to define the bottom of NP4, where E. macellus is absent due to solution or high latitude. F. magnus, a large fasciculith occurring quite suddenly in NP4 is about twice the size of the later fasciculiths in NP5 and also shows some features not found in these. Thus, the central part of the distal side is built up of concentric rings and of radial elements similar to the central distal part of D. multiradiatus. This central part is at the bottom of a cone extending inwards from the edge of the distal part of the specimen. While "normal," small fasciculiths usually have a wider distal than proximal part, and a higher proximal than distal part, the reverse is true in $F$. magnus.

The $C$. danicus Zone (NP3) extends from Section 266 to Section 28-4, where the first occurrence of $C$. danicus is easily recognizable. Common species in this zone are E. cava, small and large forms of $C$. tenuis, $P$. dimorphosus evolving into $P$. martinii in this zone, and $Z$. sigmoides. Less common are $E$. subpertusa and $H$. teuriensis, which have their first occurrence in this zone, and Thoracosphaera sp., $N$. modestus, and $N$. cf. $N$. protenus. It is worth noting that $N$. modestus, which has its first occurrence in NP3 in the type Danian, here already occurs in NP2. Scapholithus rhombiformis has its first occurrence in the upper part of this zone.

In the $C$. tenuis Zone (NP2), which includes Section 28-5 to Sample 29-1, $90 \mathrm{~cm}$, small and large forms of $C$. tenuis s. ampl. are found. The lower boundary of NP2 was set at the first occurrence of the large, easily recognizable forms which occur about $50 \mathrm{~cm}$ above the small forms (C. primus). E. cava, $P$. dimorphosus, and $N$. modestus have their first occurrence in NP2. Common species are C. tenuis, Neochiastozygus sp., $Z$. sigmoides, and Thoracosphaera, which becomes increasingly common downwards. The lowermost two samples in NP2 contain common Braarudosphaera sp. and few Micrantholithus sp., while these forms are less common ranging only from rare to few in samples above and below. Reworked Late Cretaceous coccoliths occur with varying frequency in most samples and include $M$. mura, the marker form for the latest Maestrichtian. The $C$. tenuis Zone is about 4 meters thick at Site 356, which is comparable to its thickness in Denmark, the type area of the Danian, where, however, NP2 and NP1 are missing in some sections, leading to the conclusion that $C$. danicus "appears at the base of NP1" in the Danian of Denmark (Berggren, 1972).

The $M$. inversus Zone (NP1), the lowermost Tertiary coccolith zone, extends from Sample $29-1,100 \mathrm{~cm}$ to the Cretaceous/Tertiary boundary at $29-3,33 \mathrm{~cm}$. It still includes, in its uppermost part, small forms of Cruciplacolithus, $C$. primus, and $M$. inversus is rare but more consistently present than in the younger sediments. The assemblage is dominated by Thoracosphaera with $Z$. sigmoides and $N$. cf. $N$. denticulatus few to rare, and $M$. reinhardtii, Braarudosphaera sp., $L$. duocavus, B. sparsus, Crepidolithus sp., and Biscutum sp. occurring sporadically. Here, too, reworked Late Cretaceous coccoliths occur in varying amounts in most samples. The $M$. inversus Zone is $230 \mathrm{~cm}$ thick at Site 356, a thickness comparable to sections in the type area of the Danian, where NP1 is present.

\section{Late Cretaceous and Late Albian}

Coccoliths are few to common in the Cretaceous sequence at this site. The assemblages are quite diverse 
although only poorly to moderately well preserved down to Core 38. Below, preservation is poor in most samples.

Below the Cretaceous/Tertiary boundary, where no hiatus can be resolved by coccolith or foraminiferal stratigraphy, typical $M$. mura were only found in the uppermost Maestrichtian sample, 29-3, $33 \mathrm{~cm}$. Intermediate forms between $M$. staurophora and $M$. mura could be observed also in Core $30 . N$. frequens is rare in some samples down to Sample 29-5, $100 \mathrm{~cm}$. So although no biostratigraphically resolvable nonconformity can be detected at this site, sedimentation must have been slower than normal for the type of sediment (nannochalk) present, leaving only $360 \mathrm{~cm}$ of uppermost Maestrichtian against, e.g., at least 18 meters at Site 357. L. quadratus, the next lower stratigraphic marker extends down to the core catcher of Core 31. The A. cymbiformis Zone extends down to the last occurrence of $T$. gothicus, B. parca, and $T$. trifidus, which falls in the uncored interval between Cores 32 and 33 . Core 33 can be assigned to the early Maestrichtian/late Campanian T. trifidus Zone, Core 34 to the Campanian $T$. gothicus Zone. In the uncored interval of 19 meters between Cores 34 and 35, the first occurrences of T. aculeus, $T$. gothicus, and B. parca and the last oecurrences of $M$. furcatus, $C$. signum, $S$. laffittei, and E. eximius (?) occur. Thus the T. aculeus, $B$. parca, and $E$. eximius zones as defined earlier in this chapter could not be distinguished but are missing or fall in the uncored interval. The $M$. furcatus Zone extends down to Section 40-3, with $M$. furcatus occurring rare to few. Below, in the $M$. staurophora Zone, which goes down to Section $41-4$, diversity has decreased markedly probably due to the poorer preservation of the coccoliths in the calcareous mudstone. Below the lithological break, in the limestones of Cores 41 through 44, the preservation of the coccoliths is so poor that species identification becomes difficult. The assemblage belongs to the late Albian (dated by foraminifers, Premoli Silva and Boersma, this volume) E. turriseiffeli Zone and is characterized by usually common $W$. barnesae, rare to few $E$. turriseiffeli and rare but quite consistently present Nannoconus. The presence of Nannoconus is worth special attention, since it supports a more worldwide distribution of this genus than the one suggested by Berger and Roth (1975), centered around the Tethys. In fact, Nannoconus was found as high to the north as Denmark (unpublished) where it is very rare in the Lower Cretaceous of Bornholm and was reported from Brazil (Troelsen and Quadros, 1971).

A hiatus occurs at the lithological break in Core 41 and includes the lower Turonian, the Cenomanian, and the uppermost Albian.

A. cymbiformis, which was found to be very rare in the Maestrichtian of the open ocean Site 355, is more common in the Maestrichtian and Upper Campanian of this site. $K$. magnificus, a species usually found in relatively shallow water deposits, is only rare in the Maestrichtian and occurs sporadically in the older sediments.

\section{Site 357-Rio Grande Rise}

This site was drilled to obtain a complete Neogene sequence and to sample basement. The water depth is 2086 meters. Fifty-one sedimentary cores were taken before the site was abandoned in lower Santonian limestones at a subbottom depth of 797 meters. Coccoliths are common to abundant in most Tertiary samples studied and common to few in the Cretaceous part of the sequence. Preservation is mostly moderately good in the Cenozoic and moderate to poor in the Upper Cretaceous limestones. Tables 1 and 3 show the coccolith zones recognized at this site and Tables 16 through 19 give the distribution of the calcareous nannofossils in all samples studied.

\section{Pleistocene}

The youngest coccolith assemblage recovered belongs to the early Pleistocene $P$. lacunosa Zone (NN19) which occurs in the upper part of Core 1, where $G$. oceanica and $P$. lacunosa occur together. The assemblage is dominated by small Prinsiaceae. Rare reworked discoasters, $R$. pseudoumbilica, and Eocene coccoliths were also found. C. pelagicus is rare and the whole assemblage has a subtropical aspect containing ceratoliths, $O$. antillarum, $S$. fossilis, $R$. clavigera, and S. histrica.

\section{Pliocene}

Sections $1-5$ and $1-6$ belong to the $D$. pentaradiatus Zone (NN17) and the core catcher of Core 1 to the $D$. surculus Zone (NN16), all of late Pliocene age. The assemblages are similar to those in the early Pleistocene, and discoasters are relatively few. They become more common at the top of Core 2, which still belongs to NN16. Rare $R$. pseudoumbilica are considered to be reworked down to Section 2-4, where this species becomes more common and the top of the $R$. pseudoumbilica Zone (NN15) of early Pliocene age is assumed. In Section 2-5, the last occurrences of $D$. challengeri, A. tricorniculatus and A. primus as well as $S$. neoabies and the first occurrence of $D$. asymmetricus was noted. The overlap of $A$. tricorniculatus and $D$. asymmetricus indicates the presence of the $D$. asymmetricus Zone (NN14) in this section. The rest of Core 2 belongs to the $C$. rugosus Zone (NN13), with the first occurrence of $C$. rugosus and $C$. acutus, the first birefringent ceratolith, occurring in the core catcher of Core 2. Thus, the early Pliocene seems condensed at this site and a minor hiatus might well be present and was suggested by Berggren (this volume) but not recognizable with coccolith stratigraphy.

\section{Miocene}

Miocene assemblages were found in Cores 3 through 15 and are characterized by common but often heavily overgrown discoasters. Reworked Oligocene/Eocene coccoliths occur in many samples. Zonation of the upper and middle Miocene sequence is difficult at this site due to the overgrowth on most discoasters. The presence of nonbirefringent ceratoliths down to Section 
TABLE 16

Distribution of Calcareous Nannofossils in the Neogene at Site 357

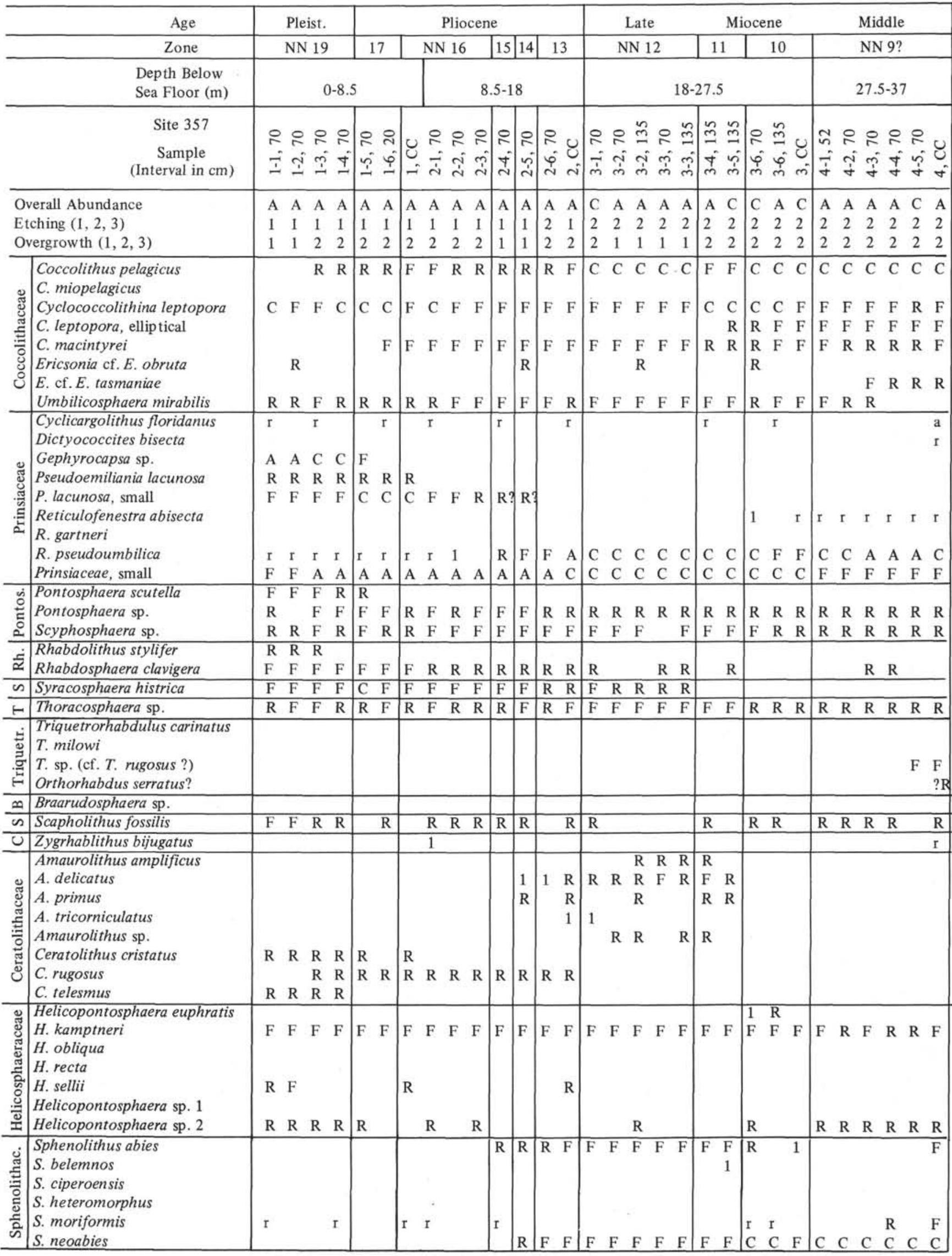


TABLE 16 - Continued

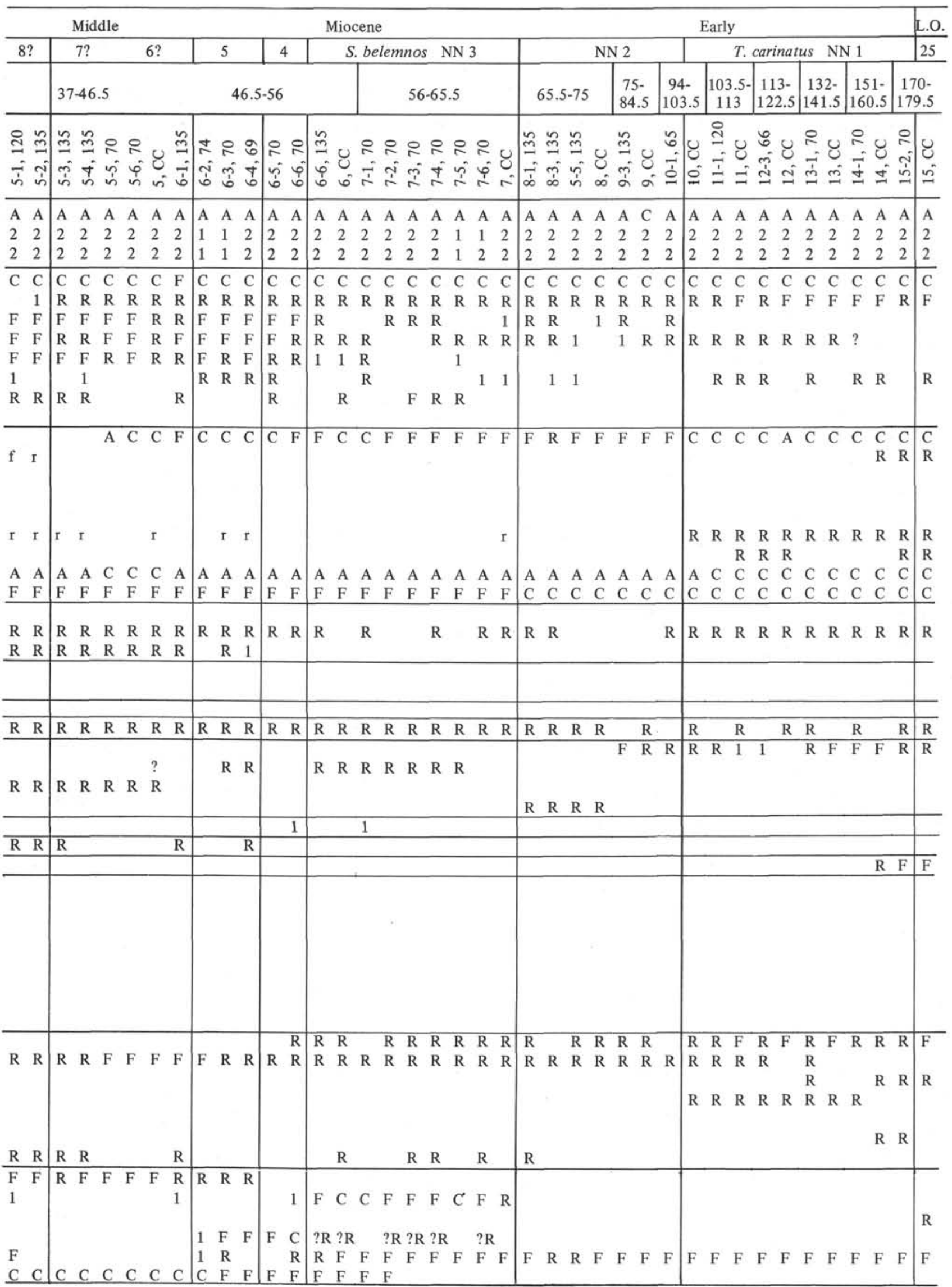


TABLE 16 - Continued

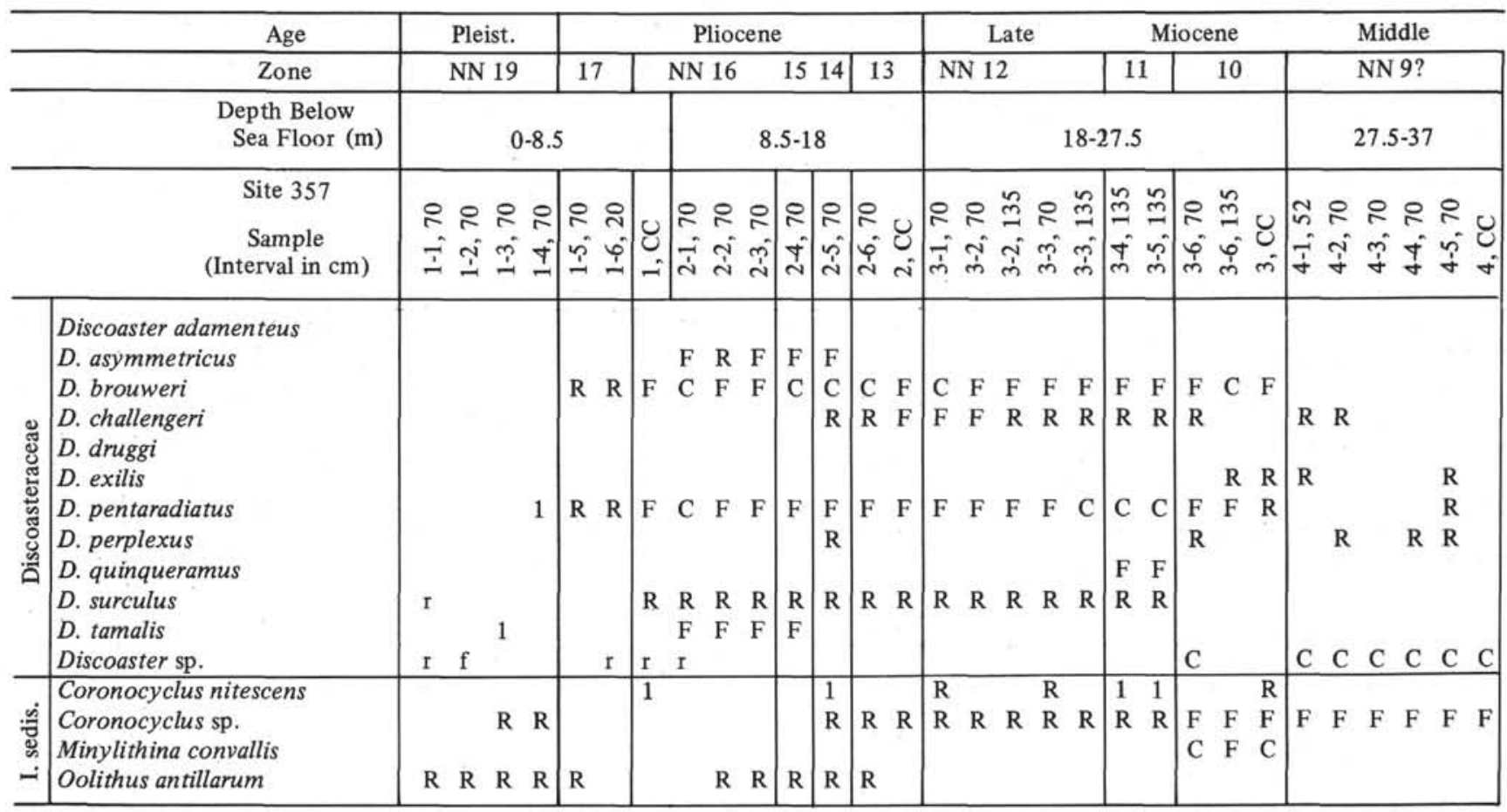

3-5, where the first occurrence of $D$. quinqueramus was observed, too, suggests this part of Core 3 to belong to the $A$. tricorniculatus Zone (NN12) down to Section 3-3 and to the D. quinqueramus Zone in Sections 3-4 and 35 , where $D$. quinqueramus occurs. The joint first occurrence of $D$. quinqueramus, $A$. primus, and $A$. delicatus and $D$. surculus in Section 3-5 indicates the sequence to be very condensed or a hiatus to be present. D. calcaris and common Minylitha convallis occur in the rest of Core 3. According to Bukry (1973c), the latter species is usually common only in the $D$. neohamatus (D. calcaris, NN10) Zone, while $D$. calcaris is reported to occur down into NN9 and NN8. Cores 4 and 5 are devoid of age diagnostic coccoliths and can only be dated indirectly as late Middle to early late Miocene due to the last occurrence of $C$. miopelagicus, which is reported to occur in the $C$. coalitus Zone (NN8) by Bukry (1973c), in Section 5-2. The last occurrence of $C$. floridanus was found in Section 5-5, suggesting the presence of the $C$. miopelagicus Zone of Bukry (1973c) or the lower D. exilis Zone (NN6). D. exilis is only sporadically present and useless as a marker fossil at this relatively high latitude. The $D$. exilis Zone extends down to the last occurrence of $S$. heteromorphus, which was observed in Section 6-2. Martini (1976) has used a combined H. ampliaperta/heteromorphus Zone (NN4/5), where $H$. ampliaperta is absent and $D$. exilis hard to identify or absent. This zone could be observed in the interval including Sections 6-2 through 6-6. Berggren (this volume) recognized a hiatus in this interval between Sections 6-4 and 6-5. This hiatus cannot be resolved by coccolith biostratigraphy. At the level indicated, however, there do occur the first occurrences of Scyphosphaera sp.,
Scapholithus fossilis, Sphenolithus abies, and the last occurrence of $H$. euphratis, thus a concentration of events can be noted. The last occurrence of $H$. euphratis is correlated by Haq (1973) with the last occurrence of $H$. ampliaperta at the top of the zone of this name. Typical and common $S$. heteromorphus occur for the first time in Section 6-6, while forms similar to $S$. heteromorphus are already rare one core deeper. $S$. belemnos and $S$. heteromorphus only overlap in Section 6-6, at the base of the $H$. ampliaperta Zone. Since $S$. belemnos and T. carinatus do not overlap at Site 357, the base of $S$. belemnos was taken as the base of the $S$. belemnos Zone (NN3) in the core catcher of Core 7. The first occurrence of $D$. druggii, defining the base of the D. druggii Zone (NN2) occurs in Section 10-1, just above the last occurrence of $T$. carinatus and $H$. recta in the core catcher of Core 10 . The occurrence of $\mathrm{H}$. recta, which was considered by $\mathrm{Haq}(1973)$ to be restricted to NP24 and NP25 of late Oligocene age in this lower Miocene sequence, is surprising and disturbing, since the top of the $S$. ciperoensis Zone (NP25) is defined by the last occurrence of $H$. recta. Thus, if the zonal definitions are taken as proposed in Martini (1971), the whole $T$. carinatus Zone is missing in a hiatus in Core 10 between the last occurrence of $H$. recta in 10, CC and the first occurrence of $D$. druggii in Section 10-1, and Cores 11 through 15 would be Oligocene in age. The coccolith assemblages and the planktonic foraminifers do not support this and Martini (1976), finding no $H$. recta at all in the Equatorial Pacific, suggested another definition for the top of NP25 instead of the last occurrence of $H$. recta, to take the last occurrence of $S$. ciperoensis as already suggested by Bukry and Bramlette (1970). This, at Site 357, occurs in 
TABLE 16 - Continued

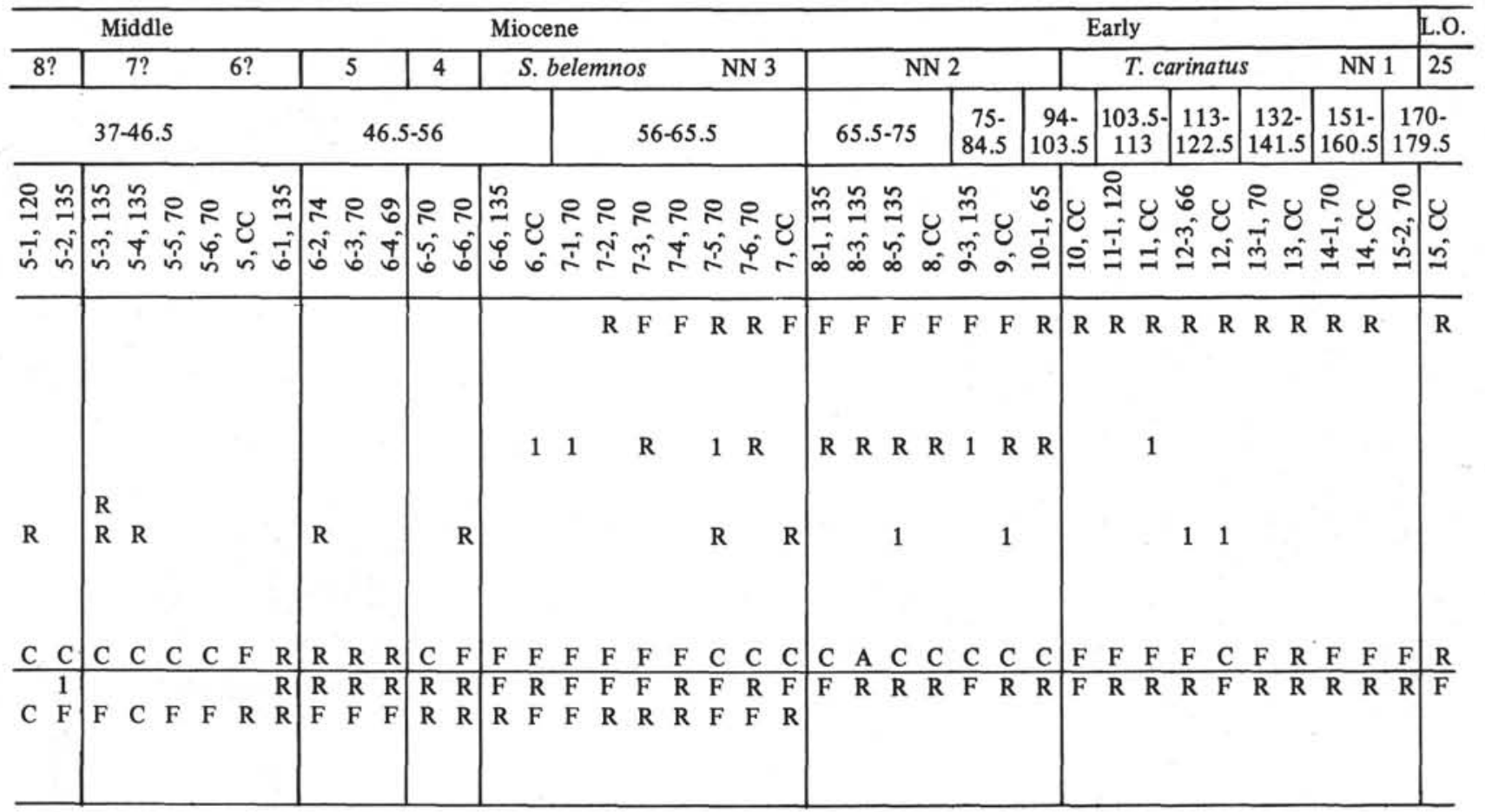

the core catcher of Core 15 , and thus the interval from $10, \mathrm{CC}$ to Section 15-2, is assigned to the $T$. carinatus Zone, NN1. Towards the base of this zone, the last occurrences of $D$. bisecta and Z. bijugatus were noted. This is in good accordance with observations in other sections.

Berggren (this volume) has suggested one definite unconformity between Sections 1-6 and 2-1, and two probable unconformities at Sections 5-4/5-5 and 6-4/65 . The first, occurring between lower Pleistocene and upper late Pliocene, falls within the $D$. surculus Zone (NN16) of early late Pliocene age, and thus could not be observed, or between the $D$. pentaradiatus Zone (NN17) and the D. surculus Zone. While Berggren (this volume) finds Core 1 to be of late Pleistocene age, coccoliths suggest an early Pleistocene age for the uppermost 4 sections and a possibly condensed upper Pliocene sequence at the bottom of the core. The second unconformity, between middle late Miocene and late middle Miocene, between Sections 5-4 and 5-5, cannot be resolved by coccoliths either, due to the lack of age diagnostic forms in the middle Miocene of this site. On the other hand, $C$. floridanus, which is abundant in Section 5-5, is absent in Section 5-4, maybe indicating a break in accumulation rather than continuous sedimentation. The third unconformity between early middle Miocene and late early Miocene, between Sections 6-4 and 6-5 also could not be detected by coccoliths, since it probably falls between two zones (NN4 and NN5) that, at this site, cannot be distinguished using the usual zonal markers. At the level indicated, however, there were observed the first occurrences of Scyphosphaera sp., Scapholithus fossilis, Sphenolithus abies, and the last occurrence of $H$. euphratis, a concentration of events unlikely to occur in a continuous section. Thus, while the unconformities could not be resolved by coccolith stratigraphy, coccolith stratigraphy does not oppose them either, and the coincidence of more than "normal" first and last occurrences of species at the intervals indicated to contain unconformities do support them.

\section{Oligocene}

Oligocene assemblages were found in the core catcher of Core 15 and in Cores 16 through 19. The sequence contains all but the lowermost zone of the standard coccolith zonation of the Oligocene. Recovery in the heavily disturbed cores was rather poor throughout the Oligocene and, since coring was not continuous, there can be doubt, as to where exactly the various parts of the recovered sediment came from. The sphenoliths, marker species of the upper Oligocene zones (Bramlette and Wilcoxon, 1967) are rare except the stratigraphically unimportant $S$. moriformis and $S$. distentus at the bottom of the Oligocene sequence. The overlap of $S$. ciperoensis and $S$. distentus, which is usually found in the $S$. distentus Zone (NP24), was observed only in the core catcher of Core 18, thus the interval above, where $S$. ciperoensis is rare but consistently present, can be assigned to the $S$. ciperoensis Zone (NP25). Since the last occurrence of $R$. umbilica occurs in the core catcher of Core 19, the rest of Core 19 can be assigned to the $S$. predistentus Zone (NP23), where $S$. distentus has its first occurrence. The Oligocene assemblages contain common $E$. ovalis, $D$. scrippsae, $R$. abisecta, few to common $D$. bisecta (only in the lower part, it is rare in NP25), $Z$. bijugatus, $S$. moriformis, and D. deflandrei. Chiasmolithus 
TABLE 17

Distribution of Calcareous Nannofossils in the Oligocene and Eocene at Site 357

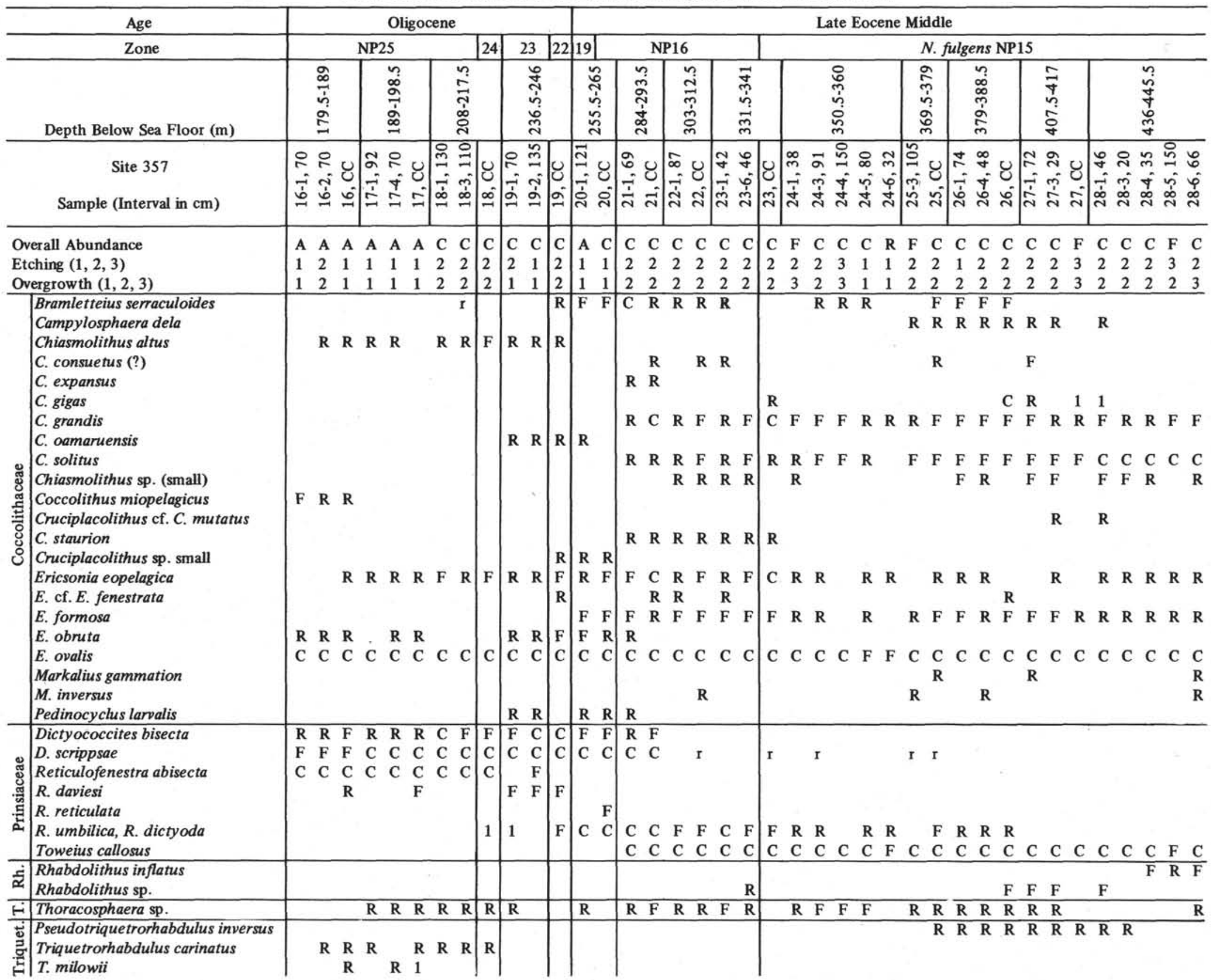




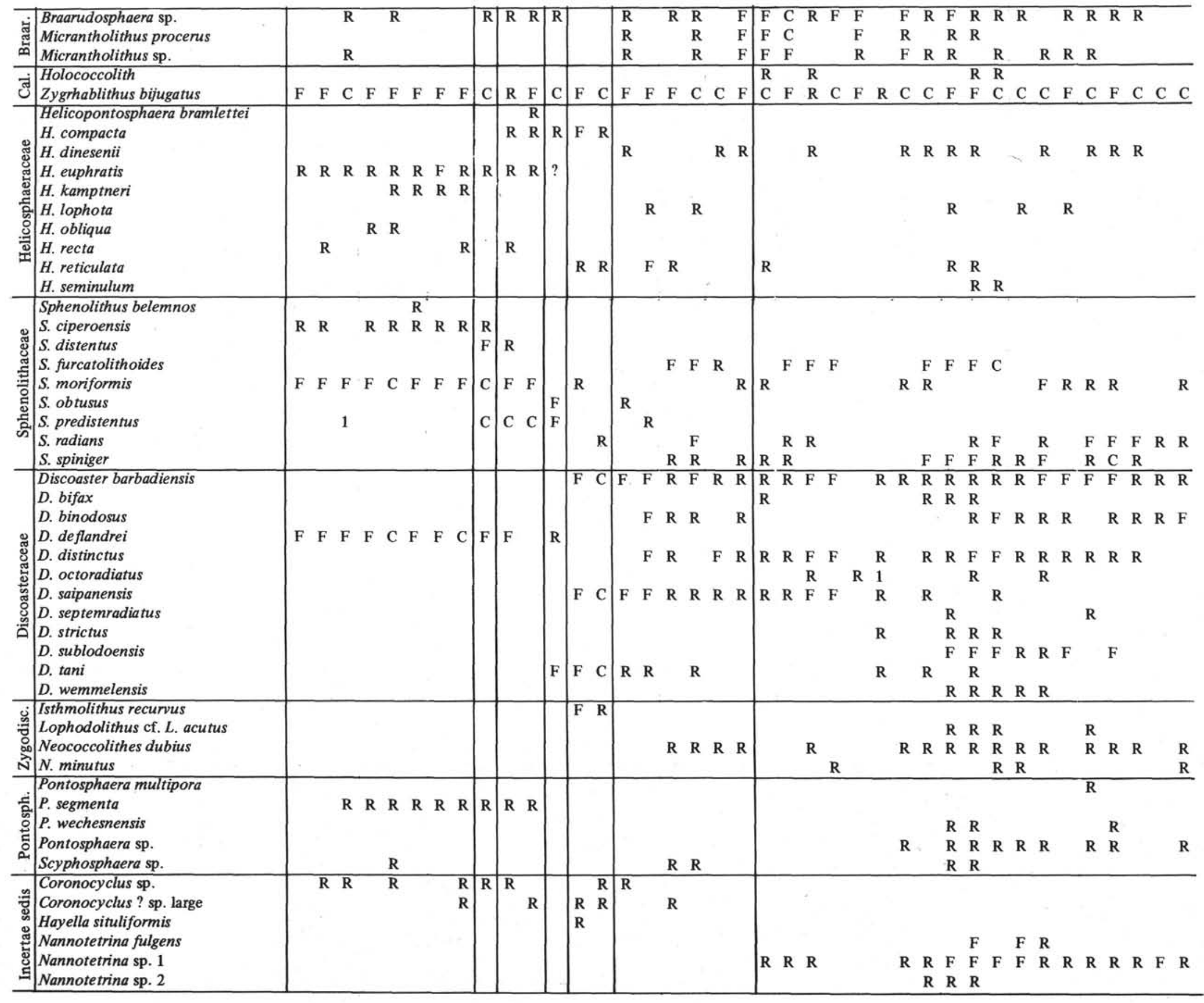


TABLE 18

Distribution of Calcareous Nannofossils in the Paleocene at Site 357

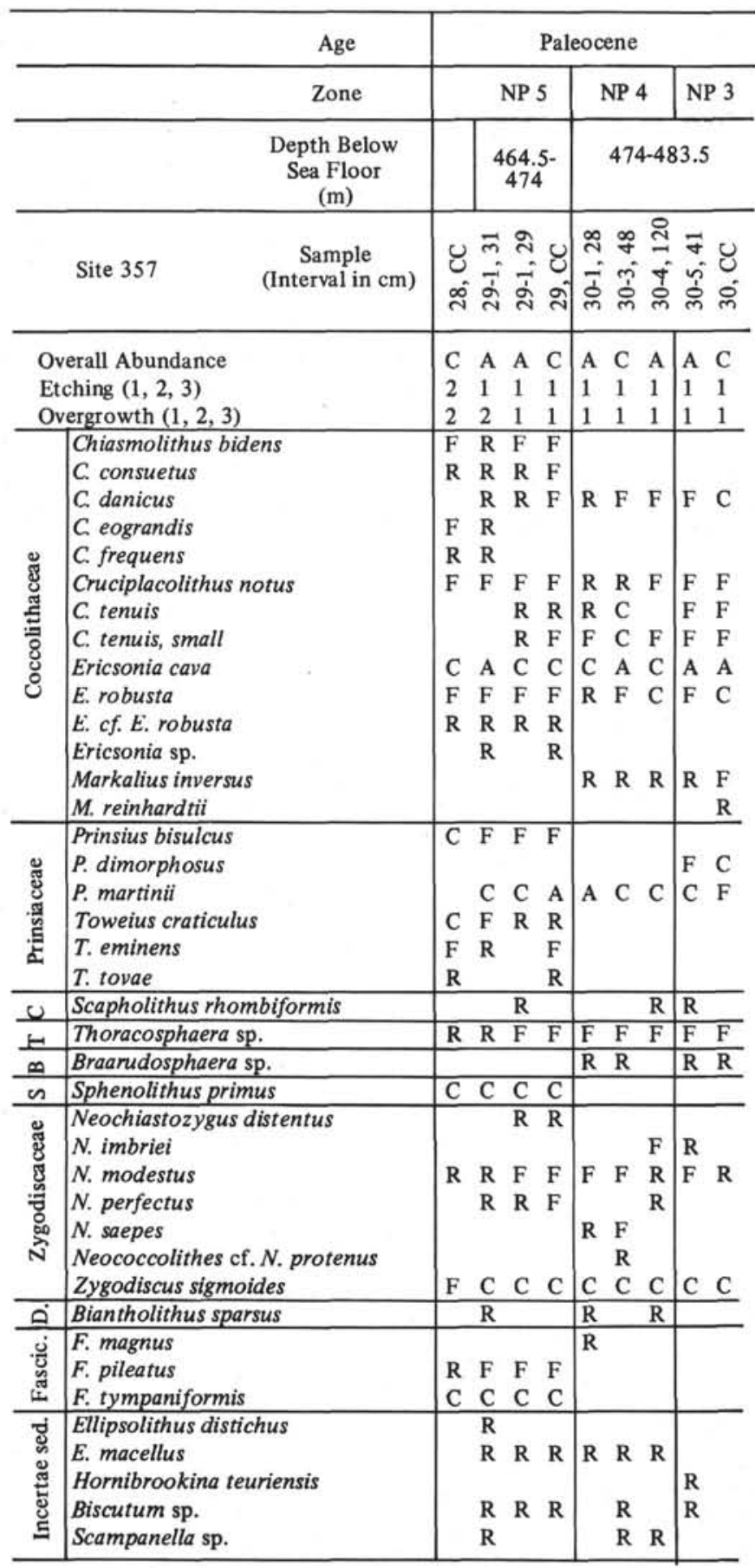

oamaruensis is rare in Core 19 and C. altus, a form typical for the high latitude Oligocene, is present but also rare in most samples. Of Helicopontosphaera, only $H$. euphratis is consistently present and $H$. compacta was found in Core 19. Triquetrorhabdulus carinatus and $T$. milowii were found in the upper Oligocene, Braarudosphaeraceae occur only in low numbers, sporadically, and the "Braarudosphaera chalk" reported from other Oligocene sites in the South Atlantic (Maxwell et al., 1970) was not found. In view of the few and widely spaced cores with low recovery, this is not really surprising and cannot be used as an argument that this chalk does not occur in the western South Atlantic. Generally, the Oligocene assemblages are less diverse than the underlying Eocene ones, a fact noted by all workers in all latitudes. The low discoaster/chiasmolith ratio indicates relatively cool conditions at this site during the Oligocene.

\section{Eocene}

There is a 9-meter uncored interval between Core 19 with a coccolith assemblage belonging to NP22 and Core 20 which belongs to NP19. Since the total recovery of Cores 19 and 20 was only 6 meters of the 19 cored, the total unrepresented interval between NP22 and NP19 might be as much as 22 meters. This still means slow sedimentation or the presence of a hiatus around the Eocene/Oligocene boundary. NP19, the $I$. recurvus Zone is present in Core 20, where $I$. recurvus is sparse and discoasters, namely $D$. tanii, $D$. barbadiensis, and D. saipanensis are few to common. The overall preservation is moderately good, thus the abundance of discoasters is not resulting from concentration by solution of coccoliths. This, together with the only rare occurrences of chiasmoliths, indicates relatively warm conditions at this site during late Eocene.

The rest of the Eocene recovered at this site belongs to the middle Eocene Zones NP16 and NP15. Here, discoasters are rare in most samples, despite poorer preservation than in the Upper Eocene samples. Chiasmoliths, on the other hand, are rare to common, thus the generally low discoaster/chiasmolith ratio suggests relatively cool conditions during the middle Eocene at this site. Common species throughout are $E$. ovalis, $T$. callosus, and $Z$. bijugatus, varying in abundance from common to rare. Other species quite consistently present but ranging only rare to few are $E$. formosa, C. grandis, and C. solitus, Bramletteius serraculoides, R. umbilica (upper part only), Thoracosphaera sp., Braarudosphaera sp., Micrantholithus procerus and Micrantholithus sp., D. barbadiensis, D. distinctus and $D$. saipanensis, and $N$. dubius. Pontosphaercea are only rare and occur sporadically. Nannotetrina sp., usually overgrown to an extent that species identification is impossible, occurs below Sect ion 23-6 where, due to the absence of the marker species $R$. gladius used by Martini (1971) for the top of NP15, the $N$. fulgens Zone, the top of NP15, is set. The first Nannotetrina sp. occurs together with the first $R$. inflatus, which was found up to Section 28-4 and assigns this interval to Bukry's (1973c) $R$. inflatus Subzone, if defined just by the presence of this characteristic species. No attempt was made to subdivide the sequence further into the subzones proposed by Bukry (1973c).

The bottom of the core catcher of Core 28 contains about $2 \mathrm{~cm}$ of sediment including a late Paleocene (NP5) assemblage. Although an unconformity is present at this site between the middle Eocene and the late Paleocene, it most probably occurs in the 9.5 meter interval that was not cored but drilled with Core 28 in place between Cores 28 and 29 , and not in the core 
catcher of Core 28. It is thought that the sample was picked up by the core catcher just before it was retrieved from the depth corresponding to the top of Core 29.

\section{Paleocene}

The Paleocene sequence at this site is short compared to the one recovered at Site 356 on the São Paulo Plateau. Coccoliths are common to abundant and fairly well preserved. Common species throughout the Paleocene (NP5 through NP3) are $E$. ovalis and $Z$. sigmoides, while E. robusta, $C$. danicus, Cruciplacolithus sp., Thoracosphaera sp., and N. modestus occur rare to common. $F$. tympaniformis and $S$. primus are common in Core 29, which was assigned to NP5, the $F$. tympaniformis Zone. Restricted to this zone are $P$. bisulcus, $C$. bidens, $T$. eminens, $N$. distentus, and various fasciculiths. NP4, the E. macellus Zone, is restricted to Sections 1 through 4 of Core 30 . It is worth noting that $N$. imbriei occurs just above and below the boundary between NP3 and NP4, as it does at Site 356. Assemblages of NP3, the C. danicus Zone, occur in the rest of Core 30, and a lump of Danian (NP3/2) sediment was found loose on top of Core 31 . Braarudosphaera sp. is occasionally rare and $H$. teuriensis was only found in one sample. $F$. magnus again occurs below the "normal" fasciculiths in the $E$. macellus Zone.

\section{Cretaceous/Tertiary Boundary}

The Cretaceous/Tertiary boundary occurs in the about 13-meter long interval not cored or not recovered between Cores 30 and 31 . The lowermost Tertiary coccolith zone represented is NP3, the uppermost Cretaceous zone is $M$. mura, the youngest Cretaceous zone. Thus only NP2 and NP1 are missing, and might, together with the lower part of NP3 and an upper part of the $M$. mura Zone, be represented in the unrecovered interval. At Site 356, where the Danian is relatively thick, NP2 is about $400 \mathrm{~cm}$ thick and NP1 amounts to $230 \mathrm{~cm}$. Thus even assuming the same relatively high sedimentation rates at Site 357 as were found at Site 356 in the Danian, there would be plenty of room to accommodate NP2 and NP1 as well as parts of the adjacent zones in the unrecovered interval of about 13 meters. Neither the coccolith assemblages in the Danian nor those in the Maestrichtian show increased solution of coccoliths in this interval and thus even more support is given to the conclusion that no major hiatus is present at the Cretaceous/Tertiary boundary at this site.

\section{Late Cretaceous}

Coccoliths are few to abundant in the Upper Cretaceous at this site and preservation deteriorated down the hole. Generally, the assemblages are similar to those reported from Site 356. M. mura occurs together with $N$. frequens down to Sample $31-3,40 \mathrm{~cm}$. $N$. frequens and $L$. quadrata have their first occurrence at the bottom of Core 32 and it must be assumed that the true first occurrence of $L$. quadratus lies in the coring gap of 9.5 meters between Cores 32 and 33 or that a minor hiatus is present here. Core 33 can be assigned to the early Maestrichtian A. cymbiformis Zone; A. cymbiformis itself is not common, but reaches few. Below the 19-meter coring interval, $T$. gothicus, $T$. trifidus, and $B$. parca have their last occurrence at the top of Core 34. The T. trifidus Zone extends from here on downwards to Section 36-6, where the first occurrence of $T$. trifidus was noted. T. gothicus and the zone of this name extend down to the core catcher of Core 37 where the last E. eximius were found. $T$. aculeus and the zone of this name were found in the core catcher of Core 38. The interval in Core 39 and the upper part of Core 40, where $B$. parca is present but $M$. furcatus is absent, was assigned to the $B$. parca Zone as defined earlier in this chapter. An interval where $M$. furcatus and B. parca overlap occurs in Cores 40 and 41 and was defined as E. eximius Zone earlier in this paper. The rest of the sequence belongs to the Santonian/Coniacian $M$. furcatus Zone and is, according to the planktonic foraminifers, of Santonian age. $M$. furcatus itself is usually rare, rarely reaches few and seems absent in some samples. Since it is also heavily overgrown in many samples, its presence is often difficult to establish in this sequence, especially towards the top of its distribution and the base of the sequence recovered.

Common species throughout the Upper Cretaceous sequence at this site are $W$. barnesae and $M$. staurophora, both forms resistant to solution and still recognizable despite overgrowth. $P$. cretacea, $C$. ehrenbergii, $S$. crenulata, and E. turriseiffeli are some other species that are present in varying amounts in most samples. L. cayeuxi and similar forms are mainly present in the Santonian. The last occurrence of typical $R$. anthophorus coincides with the last occurrence of $T$. trifidus, which allows the use of $R$. anthophorus instead of $T$. trifidus as a stratigraphic marker in high latitudes, where T. trifidus is absent. As in the Paleocene of Site 356, single specimens of nannoliths of Scampanella were found in the Santonian and Campanian. $K$. magnificus is occasionally rare except in the uppermost Maestrichtian, where it is absent. Braarudosphaera africana was found to be rare in the uppermost Santonian, B. bigelowii equally rare in the lowermost cores.

\section{Site 358-Argentine Basin}

Sixteen sedimentary cores were taken at Site 358, which was drilled to date magnetic anomaly 32 , before it had to be abandoned due to poor weather conditions, only a few meters above presumed basement. At the water depth of 4990 meters, it was no surprise that Cores 1 through 10 were barren of calcareous nannofossils, indicating that this site has been below the CCD since middle Eocene, where the oldest calcareous microfossils were found. Cores 11 through 16 contained middle Eocene to late Campanian/early Maestrichtian coccolith assemblages. Coccoliths are common in most samples, but preservation is usually poor, mainly due to dissolution but also by some overgrowth. Tables 1, 2, and 3 show the coccolith zones recognized at this site, and Tables 20 and 21 give the distribution of the calcareous nannofossils in all samples studied. 
TABLE 19

Distribution of Calcareous Nannofossils in the Cretaceous at Site 357

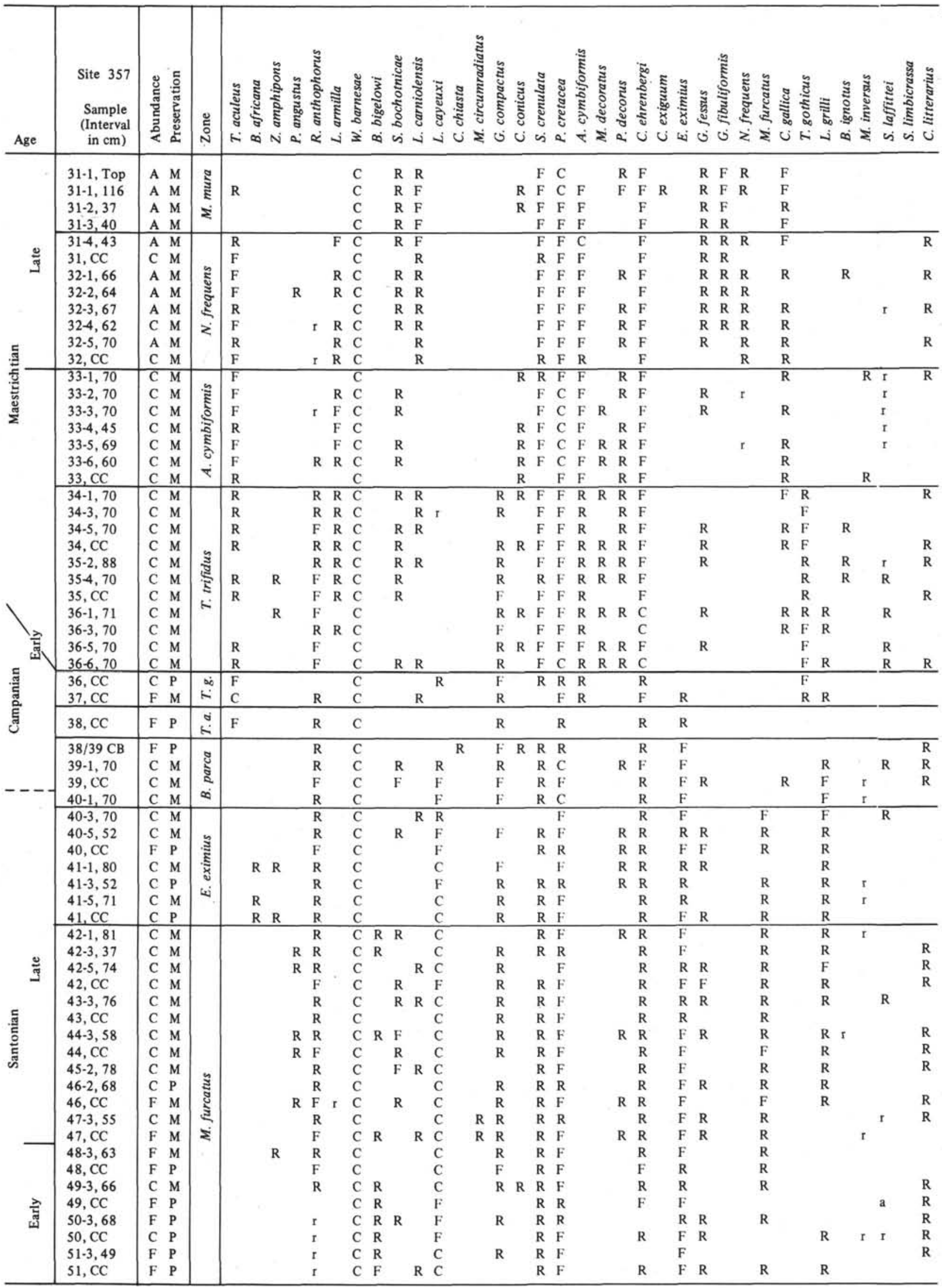


TABLE 19 - Continued

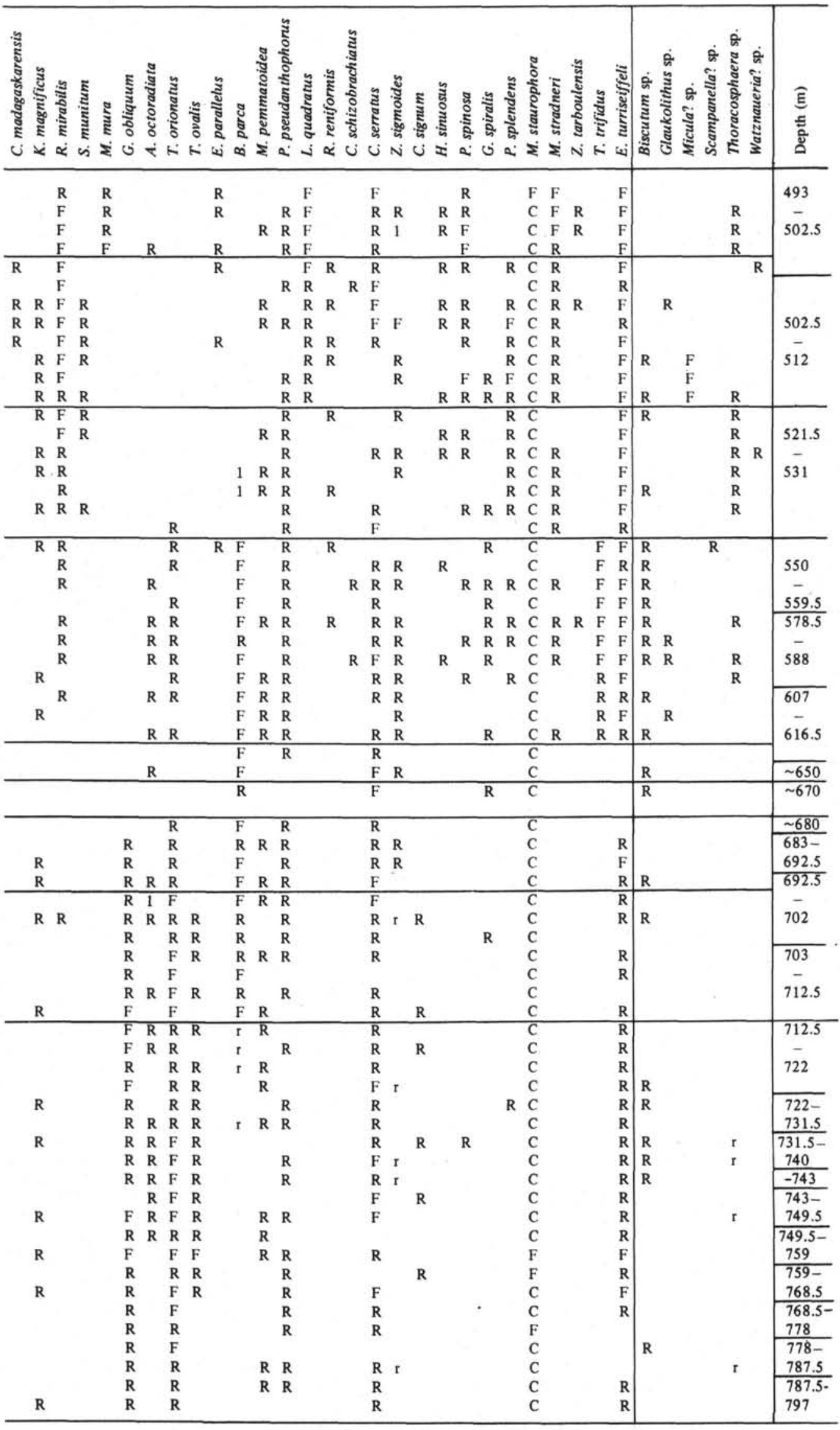


TABLE 20

Distribution of Calcareous Nannofossils in the Eocene and Paleocene at Site 358

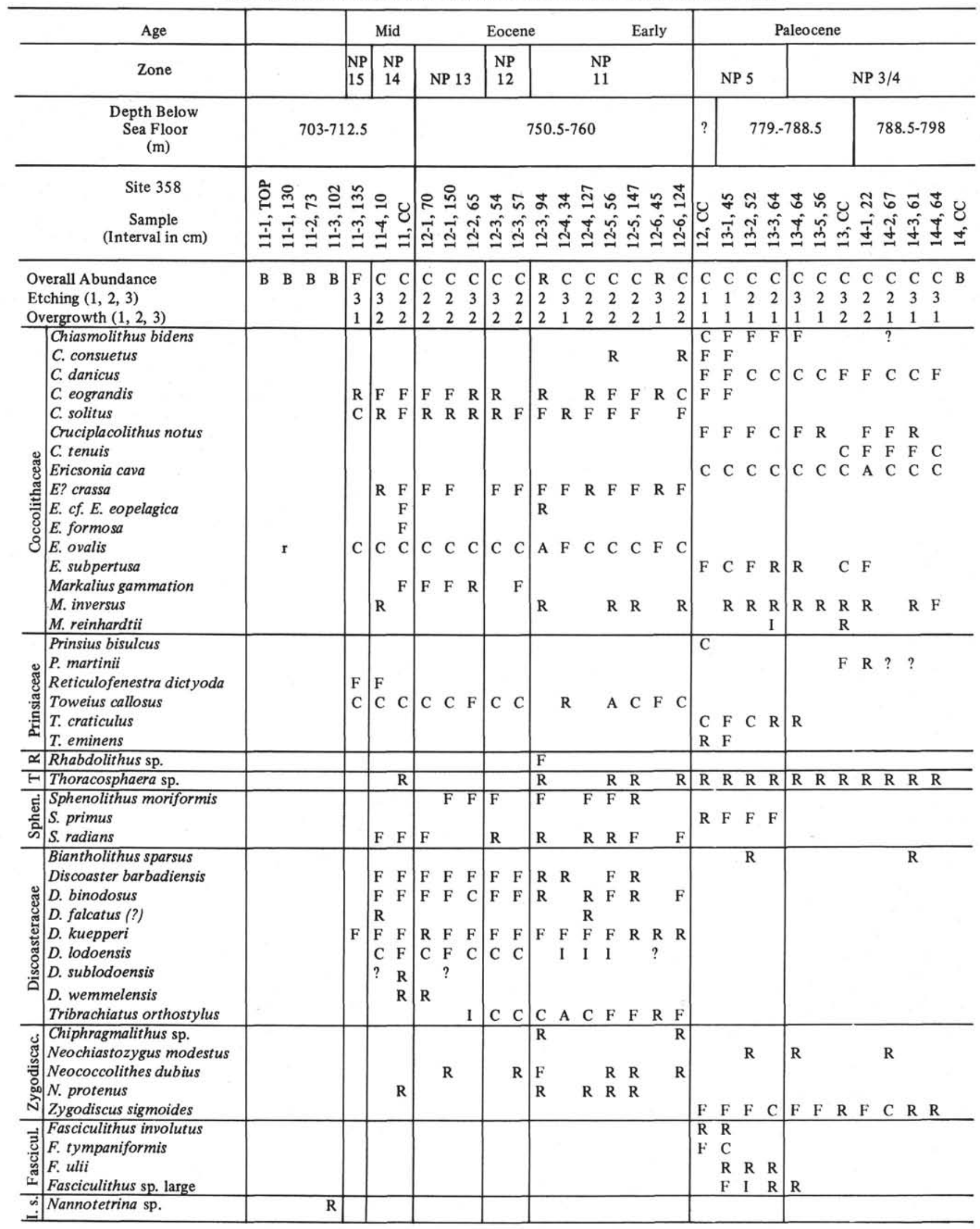


TABLE 21

Distribution of Calcareous Nannofossils in the Upper Campanian/Lower Maestrichtian at Site 358

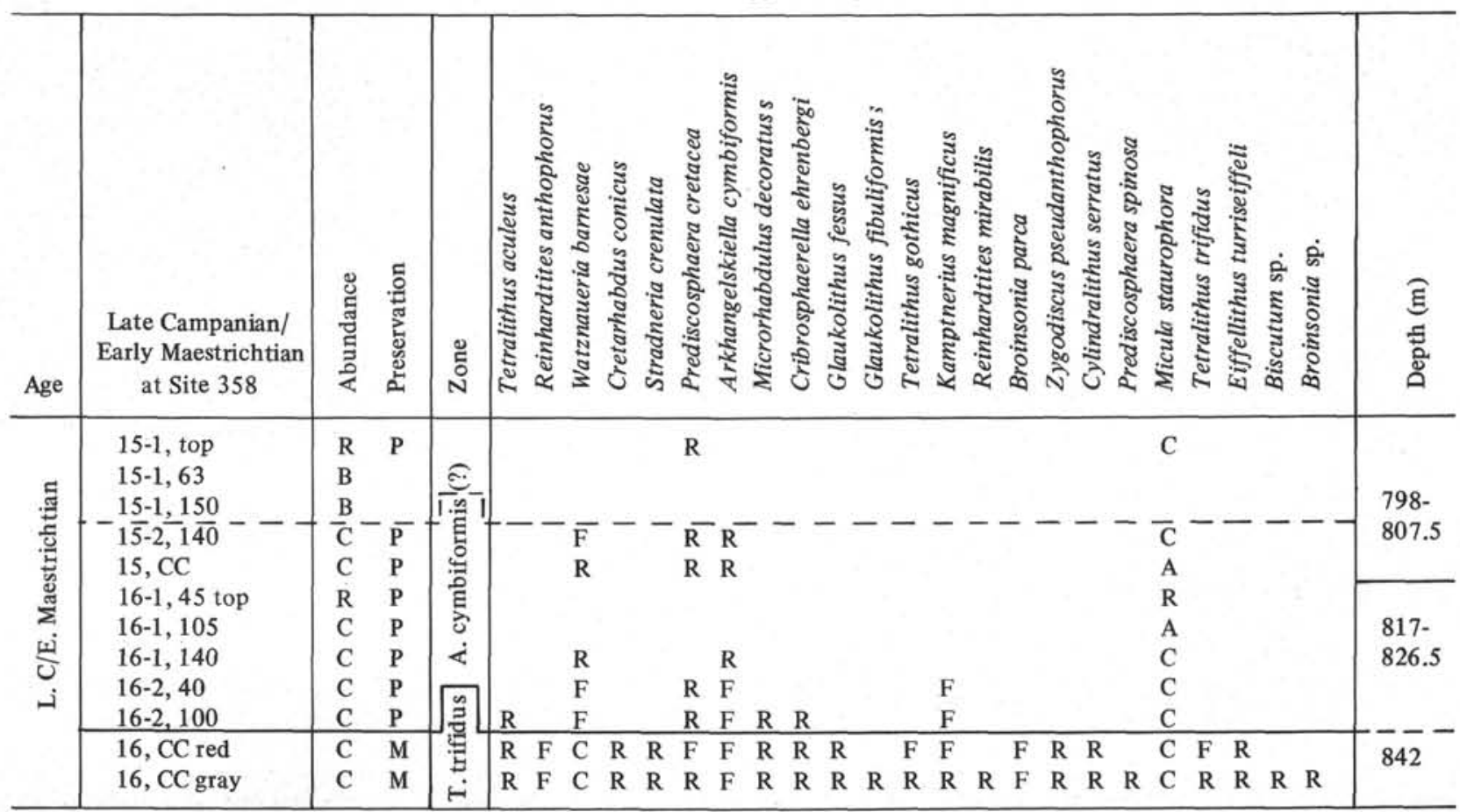

Eocene

The uppermost samples containing coccoliths were found in Section 11-3, which also contained barren samples. The assemblages are heavily marked by dissolution, but the presence of Nannotetrina sp. assigns this sample to the $N$. fulgens Zone (NP15). The fact that discoasters, which usually are concentrated in solution affected samples, are not common in this sample might indicate that they were actually not common in the waters during this time. Together with the common occurrence of $C$. solitus, the low Discoaster/Chiasmolithus ratio suggests relatively cool conditions at this site during the middle Eocene. In Sections 11-4 through $12-3$, discoasters are common and chiasmoliths rare to few, indicating warmer conditions than later.

Common D. lodoensis overlaps with common $T$. orthostylus in 12-3, $54 \mathrm{~cm}$ and 12-3, $57 \mathrm{~cm}$ and thus assigns an early Eocene age to this interval. The exact zonal assignments are difficult due to the poor preservation and probable dissolution of many coccoliths. It seems, however, that the bottom of Core 11 can be assigned to the $D$. sublodoensis Zone (NP14), since $D$. sublodoensis there overlaps with $D$. lodoensis. The $D$. lodoensis Zone (NP13) is assumed to be represented in Sections $12-1$ and $12-2$, where $D$. lodoensis is common and single specimens of $T$. orthostylus were found. The very short interval where $D$. lodoensis and $T$. orthostylus are both common is assigned to the $T$. orthostylus Zone (NP12), which is extremely thin here. In the rest of the Eocene, down to Section 12-6, T. orthostylus is consistently present, while questionable $D$. lodoensis was found only spordically. The interval was thus assigned to the $D$. binodosus Zone (NP11), which constitutes the oldest Eocene recovered at this site. The rest of the Eocene and most of the upper Paleocene are either missing or contained in the 19-meter coring gap between Cores 12 and 13. Although the core catcher of Core 12 contains a late Paleocene assemblage of the $F$. tympaniformis Zone (NP5), it is assumed that this sample was picked up after drilling with the full (Core 12) barrel in place.

\section{Paleocene}

Besides the core catcher of Core 12, Cores 13 and 14 also contain Paleocene assemblages. While dissolution is as evident here as in the Eocene samples, overgrowth has affected the assemblages much less than in the Eocene samples. The earliest small fasciculith, $F$. tympaniformis, is very rare in sample $13-3,64 \mathrm{~cm}$, so that the core catcher of Core 12 and three sections of Core 13 are assigned to the $F$. tympaniformis Zone (NP5). $S$. primus, which usually occurs together with or just below $F$. tympaniformis, was found to be quite common down to Section 13-3. Presence of a larger fasciculith, but not $F$. magnus, was noted down to Section 13-4, where the first occurrence of $C$. bidens also occurs. The interval from Section 13-4 through Section 14-4 was assigned to a combined $E$. macellus $/ C$. danicus Zone (NP4/3), since it is likely that sediments corresponding in age to the $E$. macellus Zone are represented but that, due to the strong dissolution, $E$. macellus and $E$. distichus were dissolved as they seem to be in the $F$. tympaniformis Zone. Thus the zone was not recognizable in these not very diverse assemblages. While $E$. cava is common throughout the Paleocene interval, $C$. danicus decreases in abundance down 
section, and $C$. tenuis becomes common in the lowermost sample containing Tertiary coccoliths, Sample 14-4, $64 \mathrm{~cm}$. The Danian coccolith assemblage of this open ocean site is quite different from the assemblages found at Sites 356 and 357, on the São Paulo Plateau and Rio Grande Rise, respectively, or those from shelf environments i.e., in Denmark. Thus Thoracosphaera sp. is rare here, while it is usually more common in the Danian as is Neochiastozygus. P. dimorphosus and $P$. martinii, small species usually common in the Danian are absent or rare only, possibly due to winnowing.

\section{Cretaceous/Tertiary Boundary and Cretaceous}

The Cretaceous/Tertiary boundary was cored but might not have been recovered and is not recognizable by calcareous microfossils at this site anyway. The core catcher of Core 14, which otherwise included an early Eocene coccolith assemblage, is barren of coccoliths as are some samples of Core 15 which was cut just below Core 14 but which recovered only 2.7 meters of sediment. The youngest Cretaceous coccolith assemblage was found in Sample 15-1, Top, and consists of common $M$. staurophora, all heavily affected by dissolution, and arare $P$. cretacea. In Section 15-2, the assemblage is somewhat more diverse though still affected by dissolution to an extent making it unlikely to find other than the most solution resistant species. $M$. staurophora dominates the assemblages down to Section 16-2. The interval was assigned to the A. cymbiformis Zone, since this species is present, while all zonal markers for younger zones are absent and the $T$. trifidus Zone, the next older zone, could be recognized in the core catcher of Core 16. It can, however, be argued that the absence of $M$. mura, $N$. frequens, and L. quadratus, the zonal markers for the middle and upper Maestrichtian, are absent because of dissolution rather than because of their primary absence, and that the whole Maestrichtian is represented. Preservation is somewhat better in the core catcher of Core 16 and accordingly the diversity is higher than in the overlying sediments. Sample 16, CC was probably picked up at the very bottom of the hole, after an interval drilled with the filled core barrel in place. It contained red and gray marls, both including similar coccolith assemblages. $K$. magnificus and $A$. cymbiformis are more common here than at the other deep ocean site (355).

\section{Site 359-Southwest Walvis Ridge}

Site 359 , an unscheduled site, lies on the crest of a high in the seamount province of the Walvis Ridge. The eight cores taken at this site range in age from Pliocene/Pleistocene to late Eocene, with most of the Miocene and the whole Oligocene missing. The hole bottomed in a volcanic tuff 41 m.y. old (Fodor et al., this volume). Table 3 shows the coccolith zones recognized at this site and Table 22 gives the distribution of the calcareous nannofossils in all samples studied.

\section{Pleistocene/Pliocene and Miocene}

The veneer of Pleistocene noticed by Boersma (this volume) by foraminifers was not recognized with coccoliths. The uppermost sample available, although from the top of the core, includes an early Pliocene assemblage with common $S$. neoabies, $R$. pseudoumbilica, and $C$. leptopora. Discoasters are rare and poorly preserved. While Sample 1-1, $46 \mathrm{~cm}$ includes some more delicate and "warm" forms as $S$. histrica and $S$. fossilis, these forms are missing in Sample 1, CC, which probably also is of early Pliocene age. Since ceratoliths are absent and discoasters rare and poorly preserved, precise zonal assignments are impossible in the early Pliocene as well as in the Miocene part of this sequence.

Miocene assemblages were recovered in Cores $1 \mathrm{~A}$, $2 \mathrm{~A}$, and 2 . The overlap of $C$. macintyrei with $C$. floridanus makes an early-mid Miocene age (NN5?) probable for Sections 2-1 through 2-6. Clearly, this site was under the influence of cold waters during the early Pliocene and Miocene, since discoasters are rare and ceratoliths absent.

\section{Late Eocene}

Below the hiatus cored in Section 2-6, common and fairly well preserved coccolith assemblages of late Eocene age were found down to Core 4. An early late Eocene age is indicated by the presence of $I$. recurvus and $C$. oamaruensis in the Eocene samples of Core 2, which were assigned to the I. recurvus Zone (NP19). The rest of the Eocene was assigned to NP18, the $C$. oamaruensis Zone. Besides the presence of common to few $Z$. bijugatus, the presence of few B. bigelowii, Micrantholithus ornatus, and rare Pemma sp. indicates relatively shallow conditions at this site during the late Eocene; Pontosphaera and Transversopontis, on the other hand, are surprisingly rare. Bukry (this volume) also noted the presence of Corannulus germanicus, Peritrachelina joidesa, and Scyphosphaera in the Eocene of this site.

The environment of deposition of the Eocene assemblages is clearly different from the one in the Neogene. Relatively shallow and warm waters in the Eocene were followed by nondepositing/eroding currents in the latest Eocene, Oligocene, and early Miocene and cool, deep waters, partly depositing partly not, during the rest of the Neogene.

\section{REMARKS ON SYSTEMATICS}

\section{Cretaceous}

Cretaceous coccoliths, including the marker species for the zonation of the Maestrichtian, are illustrated in Plate 48. No special effort was made to illustrate the Cretaceous flora, since the material recovered generally was less well preserved than reasonable for an extended effort with the SEM. The evolution of Micula mura from Micula staurophora has been suggested previously (Bukry, 1973b) and is well illustrated in Plate 48 . There seems to be disagreement in the literature as to just when a specimen is called $M$. mura and thus indicative for the uppermost Maestrichtian. The very elegant specimen of $M$. mura with slender arms and "fingers" was found in the lower Paleocene at Site 356. It is considered to be reworked, but probably constitutes a late form of the species, maybe so late that it has not yet been found in place in the uppermost Maestrichtian.

\section{Tertiary}

A special effort was made to illustrate the Tertiary flora recovered, but no attempt was made to bring up to date all recent taxonomic changes. The negatives of the holotypes of the new species are deposited at the SEM Lab of the Federal Institute of Technology, Hönggerberg, Zürich. 
TABLE 22

Distribution of Calcareous Nannofossils in the Pliocene, Miocene, and Eocene at Site 359

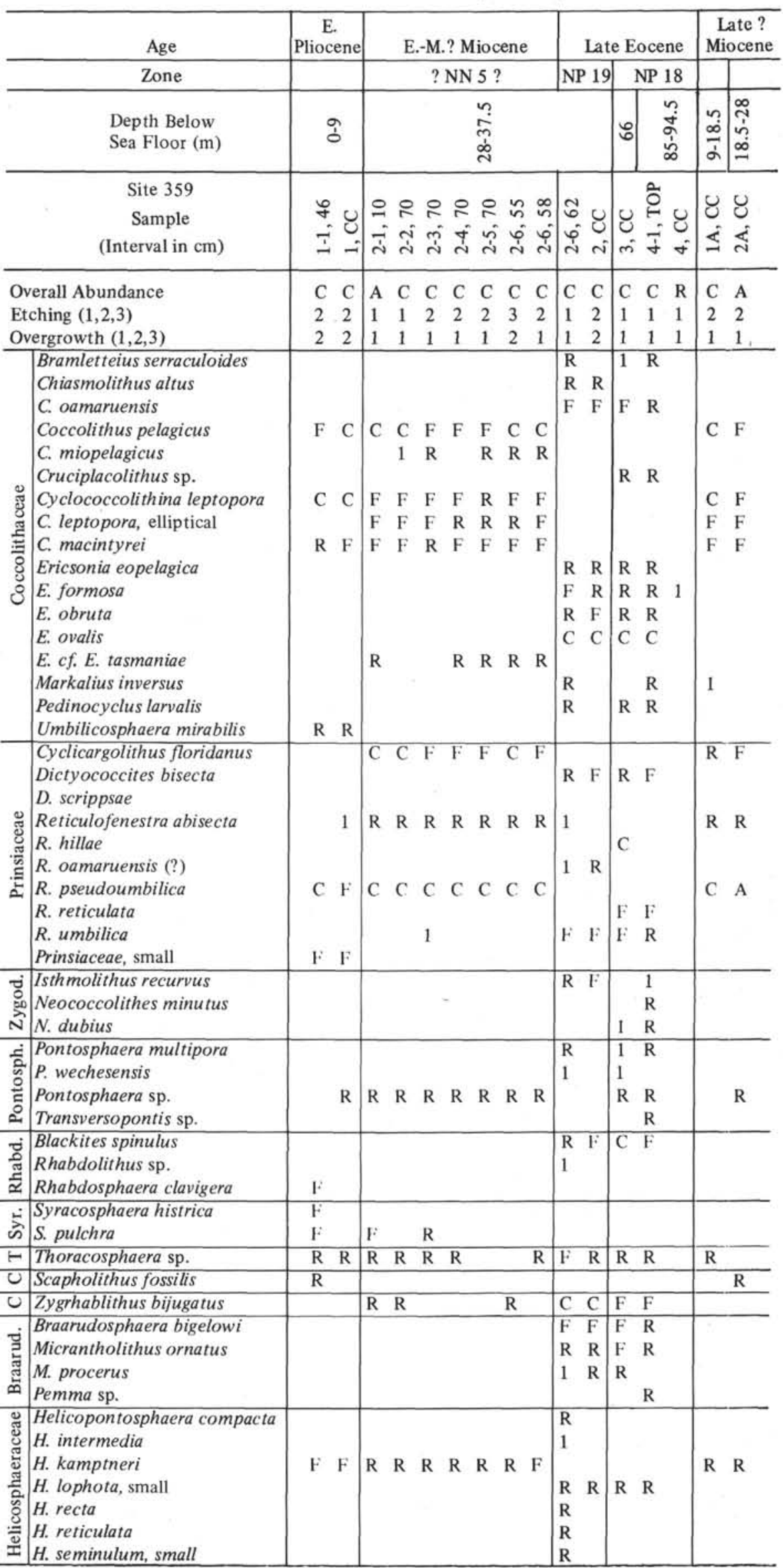


TABLE 22 - Continued

\begin{tabular}{|c|c|c|c|c|c|c|c|c|c|}
\hline Age & $\begin{array}{c}\text { E. } \\
\text { Pliocene }\end{array}$ & & E.-M.? Mi & Iiocene & & Late & Eocene & & $\begin{array}{l}\text { ate? } \\
\text { ocene }\end{array}$ \\
\hline Zone & & & $? \mathrm{NN}$ & $5 ?$ & & NP 19 & NP 18 & & \\
\hline $\begin{array}{l}\text { Depth Below } \\
\text { Sea Floor }(\mathrm{m})\end{array}$ & à & & & $\begin{array}{l}n \\
\tilde{n} \\
\infty \\
\infty \\
\infty\end{array}$ & & & 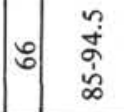 & $\begin{array}{l}n \\
\infty \\
\frac{\infty}{a}\end{array}$ & $\begin{array}{l}\infty \\
\sim \\
\sim \\
\infty \\
\infty\end{array}$ \\
\hline $\begin{array}{c}\text { Site } 359 \\
\text { Sample } \\
\text { (Interval in } \mathrm{cm} \text { ) }\end{array}$ & $\begin{array}{ll}0 & 0 \\
\pm & 0 \\
- & -1\end{array}$ & $\begin{array}{l}ㅇ ㅛ ㅁ \\
\dot{\lambda} i\end{array}$ & $\begin{array}{l}\text { 융 } \\
\dot{u} \dot{\sim} \\
\dot{\sim}\end{array}$ & $\begin{array}{l}\circ \text { : } \\
\dot{n} \\
\stackrel{n}{\sim}\end{array}$ & & $\left|\begin{array}{cc}\tau & 0 \\
0 & 0 \\
0 & 0 \\
\sim & -i\end{array}\right|$ & 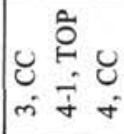 & $\begin{array}{l}\text { ¿ } \\
\leq\end{array}$ & $\begin{array}{l}\text { ¿ } \\
\text { ¿ }\end{array}$ \\
\hline Overall Abundance & $\mathrm{C} \quad \mathrm{C}$ & A C & $\mathrm{C} \mathrm{C}$ & $\mathrm{C} \mathrm{C}$ & $\mathrm{C}$ & C $\quad$ C & C $\quad \mathrm{C} \quad \mathrm{R}$ & $\mathrm{C}$ & $\mathrm{A}$ \\
\hline Etching $(1,2,3)$ & 22 & 11 & 22 & 23 & 2 & 12 & $\begin{array}{lll}1 & 1 & 1\end{array}$ & 2 & 2 \\
\hline Overgrowth $(1,2,3)$ & 22 & 11 & 11 & 12 & 1 & 12 & $\begin{array}{lll}1 & 1 & 1 \\
\end{array}$ & 1 & 1 \\
\hline \begin{tabular}{l|l} 
& Sphenolithus abies \\
S. moriformis \\
S. meoabies \\
S. ne \\
S. predistentus \\
की . pseudoradians
\end{tabular} & $\begin{array}{ll} & R \\
F & \\
C & C\end{array}$ & F $\quad R$ & $\mathrm{~F} \mathrm{~F}$ & $\begin{array}{ll}R & \\
F & R\end{array}$ & $\mathrm{R}$ & $\begin{array}{l}\mathrm{R} \\
\mathrm{R}\end{array}$ & R R & $\begin{array}{l}\mathrm{R} \\
\mathrm{F}\end{array}$ & $F$ \\
\hline 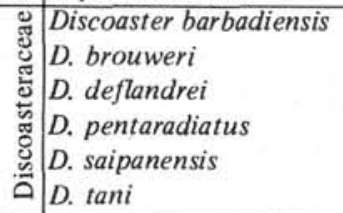 & $\begin{array}{ll}R & R \\
& r \\
R & R\end{array}$ & $\begin{array}{ll}\mathrm{R} & \mathrm{R} \\
\mathrm{R} & \end{array}$ & $R$ R & $\begin{array}{ll}R & R \\
R & \end{array}$ & $\begin{array}{l}\mathrm{R} \\
\mathrm{R}\end{array}$ & $\begin{array}{ll}\mathrm{F} & \mathrm{F} \\
\mathrm{F} & \mathrm{F}\end{array}$ & $\begin{array}{ll}\mathrm{R} & \mathrm{R} \\
\mathrm{C} & \mathrm{R}\end{array}$ & $\mathbf{R}$ & $\begin{array}{l}\mathrm{F} \\
\mathrm{R}\end{array}$ \\
\hline
\end{tabular}

In the following the genera are assigned to families following Perch-Nielsen (1971a).

\section{Braarudosphaeraceae Deflandre, 1947}

Braarudosphaera and/or Micrantholithus are very rare in the Miocene of Sites 355 and 356 and the Oligocene at Site 357, rare to few in the late Eocene at Sites 357 and 359, and very rare to rare to few at Sites 356 and 357, respectively, in the middle Eocene. Very rare occurrences were noted in the upper Paleocene at Site 356. In the lower Paleocene Braarudosphaeraceae are rare at Site 357 and absent to common at Site 356. The Oligocene Braarudosphaera chalk (Maxwell et al., 1970) was not encountered on Leg 39. This should, however, not been taken as proof of its absence in the western South Atlantic, as the calcareous Oligocene sequence was spot cored with poor recovery at Site 357 .

Braarudosphaeraceae are missing in the Maestrichtian and Campanian of all sites. They are very rare but usually absent in the Santonian and Coniacian of Sites 356 and 357, being more frequent at the latter site, where $B$. bigelowii and $B$. africana were recorded. The Turonian at Site 356 is devoid of Braarudosphaeraceae and they are rare but quite consistently present in the upper Albian at Site 356.

The significance of the presence of Braarudosphaeraceae in various amounts has been discussed and information compiled by Roth (1974), who reported on the distribution of these forms in the Indian Ocean. There seems to be evidence that recent Braarudosphaeraceae can tolerate relatively high as well as relatively low salinities and that they are most common in waters less than 100 meters and become rare below 150 to 200 meters (Takayama, 1972). This would mean that, in cases of both higher or lower salinities, braarudosphaerids could be able to persist, where other species could not. They thus become relatively more common in sediments deposited in shelf depths. Other arguments have, however, to be found to explain the common occurrence at Site 356 at the base of the lower Paleocene $C$. tenuis Zone, since this site was at a depth of at least 2000 to 2500 meters according to Sliter (this volume) during the Late Maestrichtian, or in the case of the Braarudosphaera chalk reported from various deep sites in the South Atlantic. If it is assumed that it is the ability to survive in higher and lower salinities than other genera that makes the braarudosphaerids relatively common in near-shore areas, where abnormal salinities are more likely to occur than in the open ocean, then we would have to look for mechanisms to get such conditions in the open ocean during relatively short time periods. Here, heavy rainfalls decreasing the salinity or melting ice furnishing fresh waters to the sea would have the same effects as on a relative increase of braarudosphaerids, as would excess evaporation increasing the salinity. Either of these might possibly prevail in an ocean where circulation is unable to provide enough water of normal salinity to the photic zone. In fact, both mechanisms might have reigned in different areas of the ocean at different times, the essential thing being not whether salinity was high or low, but that it differed from normal, where the bulk of coccoliths have maximum growth conditions.

Calciosoleniaceae Kamptner, 1927

Representatives of Scapholithus, a genus suggested by Deflandre (1954) to contain all fossil forms of the family Calciosoleniaceae, never occur more frequently than rare to few. S. fossilis is rare in the Pleistocene at Site 353, 354, 356, and few in 357 and is rare in the Pliocene at Sites 354, 356, 357, and 359. It occurs sporadically in the upper Miocene at Site 354 and is rare in the Miocene at Sites 357 and 359. No representatives of this family were found in any Oligocene samples and only sporadically does $S$. rhombiformis occur in the middle Eocene at Site 356. Sporadic occurrences of S. rhombiformis were also noted in the Paleocene of Sites 354 and 357, while it is rare in the Paleocene down to the middle of NP3 at Site 356. No scapholiths were found in the Cretaceous sequences drilled on Leg 39. There is no obvious reason why scapholiths are essentially missing in the Eocene, Oligocene, and lower Miocene, while being quite consistently present in younger and older Tertiary sequences.

\section{Calyptrosphaeraceae Boudreaux and Hay, 1969} (Plate 37)

The most common representative of the Calyptrosphaeraceae in the sediments studied here is Zygrhablithus bijugatus, which was found very rare and few to common in the Oligocene of Sites 354 and 357 , respectively. It is absent in the upper Eocene of Site 354, while it is few to common at Site 357 and common at Site 359 in upper Eocene sediments. In the middle Eocene, rare to few $Z$. bijugatus were found at Site 354, few at Site 356 and common at Site 357. In the lower Eocene, the species was only found at Site 356 and it is missing in the Paleocene sequences, where no similar forms were found. Lanternithus duocavus was found in the lower Paleocene (NPI and NP2) at Site 356

\section{Ceratolithaceae Norris, 1965}

(Plates 1-10, 49)

The Neogene, horseshoe-shaped calcareous nannofossils have recently been assigned to two genera: Amaurolithus and Ceratolithus. 
The species of Amaurolithus show faint or no birefringence in polarized light, while the species of Ceratolithus are characterized by strong birefringence in polarized light. Gartner and Bukry (1975) have treated the morphology and phylogeny of the Ceratolithaceae. In the present report, a special effort was made to illustrate by SEM the various ceratoliths from the Miocene and Pliocene of Site 354 on the Ceará Rise. Plates 1 through 9 show ceratolith assemblages from Site 354, in ascending order. Ceratoliths from Sites 356 on the São Paulo Plateau and 357 on the Rio Grande Rise are shown on Plates 1 and 10. The distinction between the species is not always easy and it is, of course, impossible to distinguish the two genera from SEM pictures, where the genus assignment has to be effected via the species, a somewhat backwards procedure.

\section{Ceratoliths at Site $\mathbf{3 5 4}$}

The oldest ceratolith to occur in the upper Miocene at Site 354 is $A$. primus in Sample 6-3, $90 \mathrm{~cm}$, where Discoaster quinqueramus also has its first occurrence at this site. A. delicatus occurs for the first time 10 $\mathrm{cm}$ higher, in Sample 6-3, $80 \mathrm{~cm}$. A. amplificus has its first occurrence in the lowermost sample studied by SEM for ceratoliths, $6-2,115 \mathrm{~cm}$. An uncored interval of 9 meters lies between the top of Core 6 and the core catcher of Core 5, where the oldest A. tricorniculatus, A. ninae, and $C$. armatus were observed. In Core $5, A$. delicatus shows a short apical spur or apical lump and a row of rods while the specimens in older samples are less decorated. $C$. atlanticus has its first occurrence in the core catcher of Core 4, taken 38 meters above the top of Core 5. A. bizzarus was only found in Sample $4-3,20 \mathrm{~cm}$ in the earliest Pliocene. C. rugosus is very rare and only occurs sporadically above Sample 4-1, $120 \mathrm{~cm}$, where $C$. cristatus was also found. Finally, $C$. telesmus was observed in all samples from Core 1 of late Pleistocene age.

\section{Remarks on several species}

Amaurolithus amplificus (Bukry and Percival) Gartner and Bukry, 1975

(Plate 1, Figures 1?, 2; Plate 2, Figures 3, 5, 6, 8, 11, 13;

$$
\text { Plate 10, Figures } 4,5 \text { ) }
$$

Remarks: A. amplificus is well represented in Sample 354-5, CC. The size of the apical region is considerably smaller than in $A$. ninae and $A$. primus with which it occurs in this sample.

\section{Amaurolithus bizzarus (Bukry) Gartner and Bukry, 1975 (Plate 8, Figures 2, 3, 5, 6)}

Remarks: Only complete specimens of $A$. bizzarus are readily distinguished from $A$. tricorniculatus by their long straight rod. Where the latter has broken off, the distinction can be made on the presence of other extra rods attached to the apical spine and a more pronounced bifurcation at the end of the horns. Not all specimens can, however, be assigned beyond doubt to one or the other species. A. bizzarus was found in the lowermost Pliocene at Site 354.

Amaurolithus delicatus Gartner and Bukry, 1975

(Plate 1, Figure 9; Plate 2, Figures 1, 2, 4, 7, 10, 12; Plate 4, Figures 1, 2, 4, 5; Plate 6, Figure 8; Plate 10, Figures 1, 2)

Remarks: Early forms of $A$. delicatus show a simple horseshoeshaped body sometimes armed with a short apical spur (Plate 1). In younger specimens the usually shorter horn bears a row of rods leading up to the apical spur and the size of the apical region increases (Plate 2) leading to an apical lump (Plates 2 and 4).

Amaurolithus ninae n. sp.

(Plate 2, Figures 8, 9, 14; Plate 4, Figures 3, 6-14; Plate 5, Figures 9, 12-14; Plate 49, Figure 5)

Holotype: Plate 4, Figures 3, 7.

Type level: A. tricorniculatus Zone, (NN12); late Miocene.

Type locality: Ceará Rise, Site 354.

Diagnosis: Ceratolith with a well-developed apical region and two unequal to subequal, long horns. The shorter horn bears side nodes and a row of rods on the proximal side. The longer horn and the distal side of the ceratolith are armed by non-structured keels.

Description: $A$. ninae has a very well-developed apical region extending from the proximal side of the arch and usually not directly connected with the keel or row of rods on the horns. The row of rods on the proximal side of the shorter horn stand perpendicular to the plane of the ceratolith. Side rods also occur at the boundary between the extension of the apical lump along the shorter horns and that horn itself. On the distal side, the keel is unstructured. In the light microscope, specimens of $A$. ninae show no birefringence.

Remarks: No other species of Amauroliths or Ceratolithus has an equally well-developed apical region as $A$. ninae. $A$. ninae is further distinguished from $C$. armatus by the presence of rows of rods on both horns in $C$. armatus, where one row of rods extends to the tip of the apical point. In $C$. acutus, the length of the horns is more unequal than in $A$. ninae, it has an apical suture and the row of rods stands on the longer horn. According to the description of $A$. delicatus, this species also develops an apical lump or a short apical point. Such specimens are shown on Plate 1, Figure 9, Plate 2, Figures 1, 2, 4, 7, 10,12 and Plate 6, Figure 8. In all these specimens, the row of rods and the apical lump or spine develop out of the row of rods and the proximal keel of the other horn.

Occurrence: The earliest $A$. ninae were found in the core catcher of Core 5 belonging to the late Miocene $A$. primus Subzone of Bukry (1973c) and show a deltoid apical region. The apical region is developed as an apical lump or blade in the core catcher of Core 4, from where the holotype is described. Some younger specimens in the still upper Miocene Sample 354-4-6, $76 \mathrm{~cm}$, on the other hand, have a less well-developed apical region, but better developed side nodes (Plate 5, Figures 9, 12-14). In a still younger sample, the longer horn develops into a blade (Plate 7 , Figures $3,5,8,11$ ) and the rather fragile apical structure can be broken off as on the specimen illustrated on Plate 7, Figures 8, 11.

Amaurolithus primus (Bukry and Percival) Gartner and Bukry, 1975 (Plate 1, Figures 3, 5, 6; Plate 10, Figure 3)

Remarks: The $A$. primus illustrated on Plate 1 are characterized by a large apical region. In Figure 5, a short keel can be seen on one of the horns. In Figures 3 and 6, the apical region is decorated with over 10 ridges paralleling the horns. These structures resemble the ridges in Triquetrorhabdulus rugosus, from which the ceratoliths might have evolved.

Amaurolithus tricorniculatus (Gartner) Gartner and Bukry, 1975

(Plate 6, Figures 1, 4, 7, 11; Plate 8, Figures 1, 4, 7-13; Plate 9, Figures 1, 4, 9, 12)

Remarks: In many specimens of $A$. tricorniculatus, the apical horn bears extra spines perpendicular to the plane of the ceratolith. Also, the longer horn tends to broaden towards the end. This could lead to the actual bifurcation of the longer horn in A. bizzarus, with which broken specimens of $A$. tricorniculatus can be confounded.

Ceratolithus armatus Müller, 1974

(Plate 6, Figures 2, 3, 5, 6, 9-13; Plate 7, Figures 1, 2, 4, 6, $7,9,10,12,14$; Plate 9, Figures 2, 3, 5, 6, 8, 11)

Remarks: $C$. armatus was originally described from the late Miocene/early Pliocene A. tricorniculatus Zone of the Indian Ocean, and its occurrence on the Ceara Rise is the first record outside the Indian Ocean. The earliest specimens observed by SEM, in Sample $354-4-5,20 \mathrm{~cm}$ (Plate 6), show a well-developed, almost symmetrical deltoid apical region. The horns are curved and both armed with a row of rods. Specimens are very similar, maybe somewhat more robust in Sample 354-4-3, $20 \mathrm{~cm}$ (Plate 7). In Sample 354-5-1, $120 \mathrm{~cm}$, the apical region is reduced to an apical point which lies slightly asymmetrical and some specimens show extremely long rods on both horns (Plate 9). Such specimens seem to be intermediate forms to $C$. rugosus, with which they occur.

Ceratolithus atlanticus n. sp.

(Plate 3, Figures 1-14; Plate 5, Figures 1-7, 10; Plate 49, Figures 2-4)

Holotype: Plate 3, Figures 2, 5.

Type level: $A$. tricorniculatus Zone (NN12); late Miocene,

Type locality: Ceará Rise, DSDP Site 354.

Diagnosis: Ceratolith with a long, straight rod forming an apical spine and a horn of the ceratolith. The other horn and apical spine are shorter.

Description: C. atlanticus has a broad interior curvature while the arch is almost straight. A long straight rod forms an apical spine as well as a horn. It can extend perpendicular to the plane of the ceratolith as a plane also ending in a spine. The other horn and the other apical spine are shorter and are not necessarily in the plane of the ceratolith. In the light microscope, specimens are brightest with the horns pointing about $45^{\circ}$ toward the direction of polarization. 
Remarks: C. atlanticus has the most complicated structure of all ceratoliths so far described. It differs from $A$. bizzarus and all other ceratoliths by the two apical horns.

Occurrence: $C$. atlanticus was found to be most common in the Miocene part of the A. tricorniculatus Zone on the Ceará Rise in the southwestern North Atlantic.

Ceratolithus rugosus Bukry and Bramlette, 1968

(Plate 1, Figures 7, 8, 10-12; Plate 9, Figures 9, 10)

Remarks: Specimens of $C$. rugosus are often heavily calcified. Keels, body, and row of rods cannot be differentiated any more, but keels on both sides of the horns seem to join to form a continuous structure. In this, $C$. rugosus differs from late forms of $C$. armatus, where the row of rods do not join in the apical region (Plate 9).

\section{Coccolithaceae Kamptner, 1928}

(Plates 13, 16-20, 50)

Ericsonia, Chiasmolithus, and Cruciplacolithus are the main Paleogene representatives of the Coccolithaceae at Leg 39 sites, where Bramletteius, Campylosphaera, Markalius, and Pedinocyclus were also found. In the Neogene, Coccolithus, Cyclococcolithina, and Umbilicosphaera occur with varying frequency. C. pelagicus is absent or only rare in the Pleistocene and Pliocene and becomes more common in the Miocene. Three new species, Chiasmolithus frequens, Cruciplacolithus notus, and $C$. primus, all from the Paleocene, are described below. Markalius variabilis $\mathrm{n}$. $\mathrm{sp}$. seems to be a link between coccoliths and discoasters.

\section{Chiasmolithus frequens $\mathbf{n}$. sp.}

(Plate 18, Figures 2, 4; Plate 19, Figures 1, 3, 5; Plate 50, Figures 5, 6)

Holotype: Plate 19, Figure 3.

Type level: Discoaster mohleri Zone (NP7); late Paleocene.

Type locality: Ceará Rise, DSDP Site 354 .

Diagnosis: Large form of Chiasmolithus with "feet" attached to the central cross where it joins the wall in distal view.

Description: $C$. frequens is a large chiasmolith with usually around 50 to 60 elements in the distal shield. The bars of the central cross are not equal in length and are built up of laths oriented parallel to the bar on the distal side. At the ends of the bars, "feet" in the form of one or several triangular elements, are attached to them where they join the wall. The "feet" are usually oriented counterclockwise with a smaller "heel" pointing in the other direction. The "feet" are also visible in the light microscope.

Remarks: $C$. frequens has probably been included in $C$. danicus previously, but can be distinguished from this species, which occurs much earlier, and from any other chiasmolith so far described by the presence of the "feet" in C. frequens.

Occurrence: $C$. frequens has its first occurrence just below the NP5/NP6 boundary at Sites 354 and 356 and also in NP5 at Site 357, where NP6 is not represented. It was not found in the lower part of NP5, which occurs at Site 358. The holotype is described from Sample 354-16-6, $90 \mathrm{~cm}$, which is assigned to NP7, the D. mohleri Zone and its last occurrence was noted in NP9, the D. multiradiatus Zone.

Cruciplacolithus notus n. sp.

(Plate 17, Figure 4; Plate 50, Figure 2)

Holotype: Plate 17, Figure 4.

Type level: $E$. macellus Zone (NP4), early Paleocene.

Type locality: Rio Grande Rise, DSDP Site 357.

Diagnosis: A large species of Cruciplacolithus with a central cross distally attached to the wall of the central area by counterclockwise oriented "feet."

Description: $C$. notus has an elliptical outline and the distal and the proximal shields are composed of a varying number of elements. The bars of the central cross usually are oriented parallel to the axis of the coccolith but sometimes are turned slightly towards the diagonals and the assignment of the form to Cruciplacolithus becomes problematical. Towards the wall of the central area, the legs of the central structure turn around to form "feet" by which they are attached to the rim. These "feet" are also well distinguishable in the light microscope.

Remarks: $C$, notus is usually larger than $C$. tenuis, from which it differs through the presence of the feet in the former. C. notus has been included in $C$. tenuis in the literature earlier and the new species has been suggested in a paper awaiting publication at the Sixth African Micropaleontological Colloquium, 1974 in Tunis.
Occurrence: $C$. notus was found in many Paleocene sequences. Its first occurrence was noted in the upper part of NP2, the $C$. tenuis Zone at Site 356, together with the first occurrence of $E$. cava at this site. C. notus seems most common in NP4 through NP6, the last occurrence being noted in NP9 at Site 354. The holotype is described from Sample 357-30-4, $120 \mathrm{~cm}$ of early Paleocene age (NP4).

Cruciplacolithus primus n. sp.

(Plate 17, Figures 7, 8; Plate 50, Figures 11, 12)

Holotype: Plate 17, Figure 8.

Type level: $C$. tenuis Zone (NP2), early Paleocene.

Type locality: São Paulo Plateau, DSDP Site 356.

Diagnosis: Small species of Cruciplacolithus with relatively large central opening spanned by a slender cross and bordered by a relatively steep wall.

Description: C. primus is a small species of the genus Cruciplacolithus. Despite this, the distal shield consists of about 40 elements. The central opening is bordered by a relatively narrow, steep wall and spanned by a cross leaving still quite large open quadrants in the central area. The proximal shield is double and narrow and the wall well visible also on the proximal side.

Remarks: C. primus differs from C. tenuis, with which it occurs through most of its range, by its small size, while the number of elements is similar in both species. Shields and wall are relatively broader in $C$. tenuis, thus leaving only a relatively small central opening. This is also well illustrated in the first drawing by Stradner of C. tenuis (1961), while a subsequent illustration (Stradner, 1963) shows a specimen between $C$. notus and $C$. primus.

Occurrence: $C$. primus seems to be the first modern representative of the family Coccolithaceae. Its first occurrence was observed in Sample 356-29-1, $140 \mathrm{~cm}$, some $50 \mathrm{~cm}$ below the first occurrence of $C$. tenuis. Its last occurrence has not yet been investigated, but it does occur in NP6 at Site 356.

\section{Cruciplacolithus, Ericsonia and Chiasmolithus in the Paleocene}

Site 356 yielded very fine material to study the development of the early Paleocene coccoliths of the genera Cruciplacolithus, Ericsonia, and Chiasmolithus, the earliest modern forms of the family Coccolithaceae.

The earliest Tertiary coccoliths with a double proximal shield are small forms of Cruciplacolithus, C. primus. Their central area is relatively large, the distal wall narrow and steep, and the distal shield is built of some 40 elements. C. primus was found about $200 \mathrm{~cm}$ above the Cretaceous/Tertiary boundary, and about $50 \mathrm{~cm}$ above them, the first large Cruciplacolithus, $C$. tenuis have their first occurrence. $C$. temuis has about an equal number of elements in the shields as $C$. primus, but a broader wall leaving only a small central opening spanned by a relatively small central cross. Some $80 \mathrm{~cm}$ above the first occurrence of $C$. tenuis at Site 356 , the still larger $C$. notus appears. Here, the end of the bars of the central eross have developed "feet" where they meet with the wall on the distal side of the coccolith. At the same level, Ericsonia cava has evolved, maybe from Cruciplacolithus, as a form with an extremely broad wall, leaving no room for another central structure. Chiasmolithus danicus, the first chiasmolith, occurs some $300 \mathrm{~cm}$ above the first $C$. notus and $E$. cava and probably evolved from $C$. tenuis by a rotation of the central cross. $C$. tenuis and $C$. danicus can be difficult to distinguish when the central cross of the latter is only slightly rotated. The next new form to occur is $C$. consuetus in Section $27-5$, some $800 \mathrm{~cm}$ above the first $C$. danicus is Section 28-4. The sequence probably includes a minor hiatus between Cores 28 and 27, since the foraminiferal Zone P1b seems to be missing (Boersma, this volume).

In Ericsonia, next after the elliptical E. cava, appears the round or nearly round $E$. subpertusa at about $300 \mathrm{~cm}$ above the first $C$. danicus and some $800 \mathrm{~cm}$ above the first $E$. cava. Still in NP3, the $C$. danicus Zone, $E$. robusta has evolved, thus bringing the number of Coccolithaceae to at least eight species in three genera. No further species of Ericsonia appear during the Paleocene at Site 356, while Chiasmolithus includes four more species evolving during the Paleocene: $C$. bidens in NP4, $C$. eograndis and $C$. frequens in NP5, and $C$. californicus later in the Paleocene. Finally, Campylosphaera eodela is best developed in NP9, but might have evolved earlier from an unknown ancestor, possibly a cruciplacolith.

While the genus Cruciplacolithus was only important in the Paleocene and to a lesser extent in the early Eocene, Chiasmolithus was important in the Paleocene, Eocene, and high latitude Oligocene. 
Ericsonia and, later, Coccolithus were very successful genera throughout the Tertiary and into the Recent.

In Denmark, Cruciplacolithus inseadus and C. subrotundus, as well as E. brotzenii, are found in the uppermost Danian, which includes at least NP3 and probably also corresponds to NP4. Single specimens of C. subrotundus were also observed in the material studied here.

Markalius variabilis n. sp.

(Plate 13, Figures 11, 12, 15, 16, 18-20; Plate 50, Figures 15-20)

Holotype: Plate 13, Figure 20.

Type level: Heliolithus kleinpellii Zone (NP6); late Paleocene.

Type locality: Ceará Rise, DSDP Site 354.

Diagnosis: Markalius with a reduced proximal shield and a central area varying in size.

Description: The distal shield forms a truncated, relatively flat cone. The central area in the holotype is small and slightly depressed, but can be larger and flat or even somewhat higher than the cone in specimens affected by overgrowth (Plate 13, Figure 18). The proximal shield is much smaller than the distal one (Plate 13, Figure 15) and tends to be "swallowed" by the overgrowth of the proximal part of the distal shield (Plate 13, Figures 12,16,19). A circle of tangentially oriented elements surrounds the very small center, the construction of which is not discernible due to overgrowth. $M$. variabilis has an irregular outline, probably due to varying overgrowth of the elements of the distal shield. Perfectly preserved specimens would probably be round.

Remarks: The assignment of this form to the genus Markalius was made to show the evolutionary link between the discoasters and Markalius. Generally, it is suggested here that discoasters evolved from Markalius, one of the few coccoliths which survived the extinction of most Cretaceous coccoliths, by a reduction of the proximal shield of Markalius, as is evident, e.g., in $M$. variabilis. In Discoaster mohleri, all structures except the former distal shield of Markalius have disappeared. In Discoasteroides megastypus and D. bramlettei, the elements of the distal central area have grown above the cone of distal elements. The relations between Markalius, Fasciculithus, Heliolithus, and the discoasters will be the subject of further work and will be published later.

In the light microscope, the proximal shield is not clearly visible, but a bend in the curvature of the elements of the distal shield can be seen. Between crossed nicols, only the central part shows birefringence. $M$. variabilis can be mistaken for $M$. inversus, but is easily distinguished from this form by the lack of a visible proximal shield. Also, the outline of $M$. inversus is more regular than the outline of $M$. variabilis.

Occurrence: $M$. variabilis is relatively common in Samples 354 $16-6,130 \mathrm{~cm}$ and $354-16-6,120 \mathrm{~cm}$ which belong to the late Paleocene H. kleinpellii Zone. $M$. variabilis was not found in sediments of the same age at Site 356. It seems likely, that this species was observed before, but classified as $M$. inversus.

\section{Discoasteraceae Vekshina, 1959}

(Plates 10, 13, 14, 50)

The genera Biantholithus, Catinaster, Discoaster, and Discoasteroides as well as Tribrachiatus (Marthasterites) are distinguished in this report. The only species of Biantholithus, B. sparsus, occurs sporadically in the Paleocene of Sites 356 (NPI-NP3), 357 (NP4 and NP5), and 358 (NP3/4 and NP5). Catinaster coalitus and C. calyculus were found only in the Miocene of Site 354. Of Tribrachiatus, only $T$. orthostylus was found; the interval including $T$. contortus and $T$. nunnii was not recovered during Leg 39.

No site suitable to study the early history of Discoasteroides and Discoaster was drilled on Leg 39. At Site 354 , the only site where a more or less continuous upper Paleocene sequence was recovered, it is very condensed and bioturbated, thus making the recognition of first occurrences difficult. Miocene and Pliocene discoasters are well developed and reasonably well preserved at Site 354 , while they are heavily overgrown through most of the Miocene and Pliocene at Site 357.

\section{Discoaster/Chiasmolithus ratio}

Bukry (1973a, 1975) has shown that the Discoaster/Chiasmolithus (C/D) ratio in samples of a comparable age vary from high values in low latitudes to low values in high latitudes. An abundance of discoasters was thus assumed to represent relatively warm conditions, an abundance of chiasmoliths, relatively cool conditions. A first attempt to check the validity of this assumption was made in comparing values of this ratio with the temperatures derived by ${ }^{18} \mathrm{O}$ isotope data from Site 357 by Boersma and Shackleton (this volume). They show, over a period of some $10 \mathrm{~m} . \mathrm{y}$., a decrease in temperature from $20^{\circ} \mathrm{C}$ during the early middle Eocene temperature maximum (Sample $357-26, \mathrm{CC}$; NP15) over about $13^{\circ}-14^{\circ} \mathrm{C}$ in the late middle Eocene (Sample $357-21-1 \mathrm{~cm}$; NP16), and to about $10^{\circ} \mathrm{C}$ in the late Eocene in Section 357-20-2. The D/C ratio increases from 1 over 5 to 99 , the youngest and supposedly coldest sample including only $1 \%$ chiasmoliths.

It is difficult to account for this discrepancy. Since both discoasters and chiasmoliths are relatively solution resistant, it seems unlikely that this discrepancy is due to varying preservation. The influence of evolutionary changes is unknown, but generally the diversity of both discoasters and chiasmoliths decreases from the middle to the late Eocene. The coccoliths could have been transported to their site of deposition from, in respect to the planktonic foraminiferal assemblages, relatively cooler environments in the middle Eocene and from relatively warmer environments in the late Eocene. Unlikely, too. It is just difficult to explain why the water masses in the photic zone, in which the coccoliths lived, and the water masses, in which the planktonic foraminifers which furnished the ${ }^{18} \mathrm{O}$ data lived, should have undergone opposite changes in temperatures. The possibility that the $\mathrm{D} / \mathrm{C}$ ratio is not depending on temperature but on another factor depending on latitude seems unlikely, too, since Site 357 probably did not move vertically or horizontally in a drastic way during the $10 \mathrm{~m} . \mathrm{y}$. over which the temperature drop was reported.

Instead of assuming that the temperature drop is not real or that discoasters and/or chiasmoliths changed their preferences for a certain environment over the 10 -m.y. period, I prefer to conclude that the relationship and the evolution of the relationship between the paleotemperature and the $\mathrm{D} / \mathrm{C}$ ratio over time is not yet understood.

Statements about relatively cool or warm conditions as made in the Site Reports and on Table 23 were made under the assumption that an abundance of discoasters represents warm conditions.

\section{Fasciculithaceae Hay and Mohler, 1967 and Heliolithaceae Hay and Mohler, 1967$$
\text { (Plates 10-13, 49, 50) }
$$

The only genus of the Fasciculithaceae, Fasciculithus occurs at Sites 354 and 356 through 358. The thick lower and lower upper Paleocene sequence at Site 356 furnished a good opportunity to study the early evolution of this genus, while no sequence suitable to study the continuation of this evolution and the disappearance of the fasciculiths was encountered.

The oldest nannolith assigned to the genus Fasciculithus is the very large form $F$. magnus. At Sites 356 and 357 it has its first occurrence in the early Paleocene E. macellus Zone (NP4), below the first occurrence of $F$. tympaniformis and other small fasciculiths. $F$. magnus differs considerably from other fasciculiths. Its body consists of a short, proximal part and a longer, higher distal part. The central structure of the distal side lies at the bottom of a depression in the distal part of the body. It closely resembles the central areas of Heliolithus(?) cantabriae and Discoaster multiradiatus. F. magnus appears suddenly, without any obvious ancestor. A possible ancestor could be Markalius inversus developing its small, simple proximal shield into the small, proximal part of $F$. magnus and its high, distal shield into the high distal part of $F$. magnus, thereby keeping the

TABLE 23

Climatic Trends Indicated by the Discoaster/Chiasmolithus

Ratios at Leg 39 Sites in the Oligocene and Eocene (High D/C Ratios Suggest Relatively Warm, Low D/C Ratios Relatively Cool Conditions)

\begin{tabular}{l|ccccc}
\hline \multirow{1}{c|}{ Age } & \multicolumn{5}{c}{ Site } \\
\hline Oligocene & 354 & 356 & 357 & 358 & 359 \\
Late & warm & - & cool & - & - \\
Middle Eocene & warm & - & warm & - & ?warm \\
Early & cool & cool & cool & cool & - \\
\hline
\end{tabular}




\section{K. PERCH-NIELSEN}

central depression with the concentrical rings of elements. At Site 356 , the first smaller fasciculith, $F$. ulii, occurs at the same level as the first sphenolith, S. primus. In $F$. ulii, and all younger fasciculiths, the proximal part of the body is larger than the distal one, the latter disappearing completely in species like $F$. billii, the next fasciculith to occur at Site 356. Here the distal central area is relatively flat and built up by concentric rings of elements while the proximal side is slightly conical and built by radially oriented elements. In $F$. janii, the proximal part increases in diameter towards the distal end and the outermost distal circle of elements expands over the proximal part. An inner circle of the distal central area is slightly elevated, while the center itself is usually depressed. This "distal shield" has great similarity with the distal side of $D$. multiradiatus. In Bomolithus elegans, which seems to have its first occurrence at about the same level as $F$. janii, two circles of distal elements occur. Its distal view is unknown but quite likely similar to the one in $F$. janii.

The genus Bomolithus can be regarded as an early form of the family Heliolithaceae. It occurs in Core 356-23, while Heliolithus (?) cantabriae was found in Section 356-18-1 and H. kleinpellii in Sample 356-17, CC. $H$. riedelii was not found in Leg 39 material, but $H$. (?) conicus occurs in the upper Paleocene at Site 354.

Fasciculithaceae and Heliolithaceae are restricted to the uppermost lower and to the upper Paleocene while the Sphenolithaceae, which evolved at about the same time as the Fasciculithaceae, and the Discoasteraceae are known throughout the rest of the Tertiary until they disappear in the early and late Pliocene, respectively.

\section{Goniolithacéae Deflandre, 1957}

Goniolithus flückigeri, the only species in this family, was only found in the Paleocene at Site 356, where it is extremely rare.

\section{Helicosphaeraceae Black, 1971b}

$$
\text { (Plates 21-26) }
$$

The earliest Helicopontosphaera was found in Sample 354-15-2, 113 $\mathrm{cm}$ of late Paleocene age (NP9) and designed $H$. cf. $H$. seminulum. Most species of the genus were found in Leg 39 material with the notable exception of $H$. ampliaperta. The last occurrence of the latter species defines the top of NN4, the $H$. ampliaperta Zone of Martini, 1971. According to Haq (1973), the last occurrence of $H$. euphratis coincides with the last occurrence of $H$. ampliaperta. In our material, however, H. euphratis seems to extend to near the last occurrence of Sphenolithus heteromorphus at the top of NP5, the $S$. heteromorphus Zone.

H. granulata is especially well developed in the lower Miocene at Site 356 , where it occurs earlier than indicated by $\mathrm{Haq}(1973)$ and has an even larger almost quadrangular terminal flange than in the type material.

\section{Lithostromationaceae Haq, 1967}

No representatives of the Lithostromationaceae were observed in Leg 39 material.

\section{Pontosphaeraceae Lemmermann, 1908}

(Plates 27-29)

No attempt was made to distinguish all species in the genera Pontosphaera, Scyphosphaera, and Transversopontis in the range charts presented in this report. Lophodolithus is especially well represented in the middle Eocene at Site 356, where most previously described species of this genus were found. Pontosphaera is usually rare but quite consistently present in the Eocene through the Plio-Pleistocene at all sites except Site 358. Scyphosphaera is also present in most samples containing Pontosphaera, including in upper Oligocene and Eocene sediments.

In the Eocene, $S$. expansa and $S$. tercisensis were found at Sites 357 and 356 , where $S$. columnella, $S$. tubicena and an unnamed, barrelshaped form also occur.

The earliest Pontosphaera was found in the lower upper Paleocene at Site 356. Crepidolithus, a Cretaceous and Jurassic form of the family, occurs sporadically in the Paleocene at Site 356.

\section{Prinsiaceae Hay and Mohler, 1967}

(Plate 30)

Besides the Coccolithaceae, the Prinsiaceae are the most common coccoliths in all Tertiary samples except some special assemblages in the lower Paleocene dominated by Thoracosphaera and/or Braarudosphaera or Miocene assemblages dominated by discoasters due to dissolution of most coccoliths.
The earliest form of this family, Prinsius dimorphosus, has its first occurrence at the base of NP2, the C. tenuis Zone at Site 356, where it is common. In NP2 it is, however, missing or very rare in some samples, especially where Thoracosphaera is common. The next species to evolve is $P$. martinii around the base of NP3, the $C$. danicus Zone. Only in NP5, the F. tympaniformis Zone, does the first Toweius occur; $T$. craticulus occurs later, followed by $T$. eminens and, subsequently, $T$. tovae. At Site 354, P. bisulcus and T. callosus occur in NP8, the D. nobilis Zone and NP9, the D. multiradiatus Zone. Small unnamed forms of this family are found in all Paleocene sequences.

In the Eocene, the first occurrence of Reticulofenestra umbilica is difficult to define, since $R$. dictyoda (sensu Perch-Nielsen, 1971) and $R$. samodurovii, both essentially smaller forms of Reticulofenestra than $R$. umbilica but otherwise very similar to this species, are difficult to distinguish from "true" $R$. umbilica. Similar difficulties arise in the distinction of Dictyococcites scrippsae and the younger and larger $D$. bisectus.

\section{Rhabdosphaeraceae Lemmermann, 1908 (Plates 37, 49)}

Blackites, Discosphaera, Rhabdolithus, and Rhabdosphaera are the representatives of the Rhabdosphaeraceae in the Leg 39 material. It seems possible at least that some forms of Scyphosphaera in the Eocene also belong to this family.

\section{Sphenolithaceae Deflandre, 1952}

(Plates 10, 12, 31-35, 49)

Many species of the stratigraphically important family Sphenolithaceae were encountered in Leg 39 material and are illustrated in this report.

The first sphenolith, $S$. primus, occurs at about the same time as the first small fasciculith, but later than the large $F$. magnus, at the base of NP5, the F. tympaniformis Zone of early late Paleocene age. S. primus is accompanied in NP6 and the rest of the Paleocene by $S$. anarrhopus. While the fasciculiths, helioliths, and later the discoasters diversified intensively during the late Paleocene, the sphenoliths only produced two species. Sphenolithus, on the other hand, continued to produce new forms until the Miocene and the last sphenoliths disappeared in the Pliocene, while fasciculiths and helioliths disappeared already at the end of the Paleocene.

In the Eocene we see the evolution of some 10 species, of which $S$. radians, $S$. furcatolithoides, and $S$. predistentus are best represented in the Leg 39 material. During the Oligocene, another nine species evolved. Of these, $S$. distentus and $S$. ciperoensis are the stratigraphically most important or most used; they also occur in the scarce Oligocene material collected on Leg 39 . The high diversity of the sphenoliths in the Oligocene, where only relatively few new other taxa evolve cannot yet be explained. The Miocene contains the last three new spehnoliths $S$. heteromorphus, $S$. abies, and $S$. neoabies, the latter being the last sphenolith to disappear in the Pliocene. They are all well represented in the material studied here.

\section{Syracosphaeraceae Lemmermann, 1908}

$$
\text { (Plates 27, 43) }
$$

Species of the genus Syracosphaera are difficult to distinguish in the light microscope and no special attempt was made to investigate the genus with the SEM, although very little is known about the fossil representatives of the genus. $S$. pulchra and $S$. histrica occur in the Pliocene and Pleistocene at Sites 354, 356, and 357, where the genus was also observed in the uppermost Miocene samples, as it was at Site 359.

A single specimen of a questionable Syracosphaera was found in the lower Paleocene of Site 356 (Plate 43).

\section{Thoracosphaeraceae Schiller, 1930}

Futterer (1976) has shown Thoracosphaera to be calcareous dinoflagellate cysts and not coccolithophorids, to which group they have been assigned in the literature previously. They were, and probably will continue to be, treated with the coccolithophorids because of their co-occurrence with coccoliths in the microscopic slides. In fact many fossil genera and families now treated as coccolithophorids might well belong to other groups as well.

The dinoflagellate nature of Thoracosphaera might explain this genus's abundant presence in the earliest Paleocene, when only few Cretaceous coccoliths were still living and only few new Tertiary coccoliths had as yet evolved. While Thoracosphaera occurs also in 
the Maestrichtian at several sites, it reaches common and abundant frequencies in the lowermost Danian (NP1 and NP2) at Sites 354 and 356. It also dominates the assemblages of slumped material in Sections 356-24-3 and 4. This is in contradiction to Haq and Lohmann (1975) who suggested a Thoracosphaerid- $M$. astroporus (inversus) assemblage to be predominant in high latitudes only.

The ability of dinoflagellates to produce calcareous cysts was certainly present before the Tertiary; the extinction of most coccolithophorids and planktonic foraminifers at the Cretaceous/Tertiary boundary left a niche for calcareous plankton which was readily filled by Thoracosphaera and led to rock forming abundances in the early Paleocene in the southern as well as in the northern Atlantic.

No attempt was made to distinguish the various species of Thoracosphaera in the range charts of this report.

Triquetrorhabdulaceae Lipps, 1969

(Plates 36, 37, 49)

One Eocene and five Oligocene/Miocene species had previously been assigned to Triquetrorhabdulus. All but $T$. striatus were found in the Leg 39 material and are illustrated on Plates 36 and 37. While the Oligocene/Miocene forms are more or less a uniform group reasonably well suited to be united in a genus, $P$. inversus, the Eocene species shows a structure quite different from the other species of Triquetrorhabdulus and has recently been assigned to a new genus, Pseudotriquetrorhabdulus. In fact, $P$. inversus might well be the distal part of a sphenolith, of which no complete specimen has yet been found.

The first species of Triquetrorhabdulus are $T$. carinatus and $T$. milowii which occur in NP24/NP25 in the late Oligocene at Sites 354 and 357 . The new species $T$. challengeri was mainly found in the early Miocene $D$. druggii Zone (NN2) at Site 356 and $T$. rugosus occurs in the middle and late Miocene. It might be more than a coincidence that the last occurrence of Triquetrorhabdulus is found only slightly higher than the first occurrence of the ceratoliths, namely Amaurolithus primus. This species could be a descendant of $T$. rugosus. Comparing T. rugosus on Plate 36, Figure 2, and A. primus, Plate 1, Figure 36, the similarity of the fine structure is amazing. Low ridges running perpendicular to the main ridge of $T$. rugosus correspond to low ridges running parallel to the arms of $A$. primus. The non-birefringent $A$. primus could have evolved from $T$. rugosus by the loss of the main ridge, the only birefringent part of $T$. rugosus and a slight, then stronger bending of the remaining part of the body.

\section{Triquetrorhabdulus challengeri $\mathbf{n}$. sp.}

(Plate 36, Figures 3, 7, 8, 10, 11; Plate 49, Figure 1)

Holotype: Plate 36, Figure 3.

Type level: Discoaster druggii Zone (NN2); early Miocene.

Type locality: São Paulo Plateau, DSDP Site 356.

Diagnosis: Triquetrorhabdulus with a leaf-like outline and prominent parallel ridges.

Description: $T$. challengeri consists of a leaf-like body with a prominent central ridge parallel to the elongation of the body. A varying number of other parallel ridges, usually 4 to 6 , decorates the "distal" part of the body. The "proximal" part of the body shows a depression along the middle of the "leaf," but no ridges.

Remarks: The only other Triquetrorhabdulus with more than one prominent ridge is $T$. striatus. In this form, the ridges are not parallel as in $T$. challengeri, but merge towards the pointed end of the body. $T$. challengeri is also easily recognizable in the light microscope, where maximum birefringence is observed when the specimen is oriented about $45^{\circ}$ to the plane of polarization.

Occurrence: $T$. challengeri was only found in the lower Miocene at Site 356 , where it occurs with varying frequency but usually is only rare.

\section{Zygodiscaceae Hay and Mohler, 1967}

(Plates 27, 38-40, 49)

The importance and abundance of the Zygodiscaceae decrease from the Paleocene through the Eocene until their gradual disappearance in the early Oligocene. Zygodiscus sigmoides, one of the few Cretaceous species surviving in the Tertiary, occurs at all sites containing Paleocene. The early evolution of Neochiastozygus needs further study but already several forms can be used for the subdivision of the Paleocene. In the type Danian, the first Neochiastozygus to occur is N. modestus, in the upper part of NP3. In the uppermost Danian, $N$. saepes is found and $N$. perfectus characterizes the "Selandian," the lower upper Paleocene of Denmark. At Site $356, N$. modestus was found as low as NP2. N. saepes or forms similar to it at the top of NP3 and the bottom of NP4 and $N$. perfectus higher in NP4 and in the lower part of NP5. N. imbriei, a very characteristic form recently described by $\mathrm{Haq}$ and Lohmann (1975) occurs around the NP3/NP4 boundary at Sites 356 and 357.

In the Eocene, Zygodiscus sigmoides has disappeared but $Z$. adamas and similar forms were found sporadically, as were Neococcolithes dubius, $N$. protenus, and $N$. minutus. Isthmolithus recurvus occurs rare to few in the lower Oligocene at Site 357, and in the upper Eocene at Site 359 , while only single specimens were noted in the upper Eocene and lower Oligocene at Site 354.

Neochiastozygus cearae n. sp.

(Plate 40, Figures 4-6; Plate 49, Figures 9, 15)

Holotype: Plate 40, Figure 6.

Type level: Discoaster nobilis Zone (NP8); late Paleocene.

Type locality: Ceará Rise, DSDP Site 354 .

Diagnosis: Neochiastozygus with a very narrow central cross, leaving two large central openings only.

Description: The outer and the inner wall are well developed in $N$. cearae. The central cross is so narrow that it leaves only two large central openings instead of the four that are normally found in Neochiastozygus.

Remarks: $N$. cearae is distinguished from all other species of Neochiastozygus by its very narrow central cross. $N$. junctus, a similar species, has two large and two very small central openings and the central cross is built by smaller elements than in $N$. cearae. In $N$. cearae, Neochiastozygus shows fetures of late Zygodiscus and early Transversopontis. In both these genera, however, the connection between the central structure and the wall is different.

Occurrence: $N$. cearae was only found in the upper Paleocene at Site 354, mainly in NP8, from where the holotype is described.

\section{"Incertae Sedis"}

Some forms considered earlier (Perch-Nielsen, 1971a) under "incertae sedis" have been included in families on the range charts in this report: Bramletteius in Coccolithaceae, Catinaster in Discoasteraceae and Pedinocyclus in Coccolithaceae. Others are discussed below and a special effort was made to illustrate these forms.

\section{Coronocyclus Hay, Mohler, and Wade, 1966 (Plate 41)}

Coronocyclus nitescens occurs consistently in Oligocene and Miocene sediments recovered on Leg 39, while $C$. prionion was found in the Oligocene at Site 357 only.

\section{Ellipsolithus Sullivan, 1964 \\ (Plates 42, 43, 49)}

Ellipsolithus macellus and $E$. distichus were found in the Paleocene of Sites 354, 356, and 357 but not at the open ocean Site 358. A new form, E. bollii was observed at Site 356 in NP5 and NP6. Ellipsolithus has been included in different families by different authors, the Prinsiaceae by Hay and Mohler (1976) and the Syracosphaeraceae by Perch-Nielsen (197la), but because none of the previous assignments are satisfactory, it is here treated under "incertae sedis" genera.

Ellipsolithus bollii n. sp.

(Plate 43, Figures 1, 3, 5-7; Plate 49, Figures 6-8)

Holotype: Plate 43, Figure 3.

Type level: Fasciculithus tympaniformis Zone (NP5); late Paleocene.

Type locality: São Paulo Palteau, DSDP Site 356.

Diagnosis: Ellipsolithus with a central area with a low ridge along the longer axis of the ellipse and a high number of small depressions or holes varying in size. The central area comprises about one-third or less of the width of the coccolith.

Description: The distal shield of $E$. bollii consists of about 80 elements. The central area is only slightly lower than the distal shield and a ridge extending along the longer axis of the ellipse reaches about the height of the shield. To both sides of this ridge, the central area is covered but pierced by a varying (high) number of holes of varying size. The proximal shield is small (broken?) and its elements continue into and form the flat proximal, perforated central area. In the light microscope, the ridge as well as the openings can be distinguished. 
Remarks: $E$. bollii differs from $E$. macellus by the presence of small openings in the former. It differs from $E$. distichus by the presence of large openings in a relatively larger central area in $E$. distichus. $E$. lajollaensis from the Eocene has only about half the elements in the rim, but has also a relatively small central area. In $E$. distichus the central area occupies about half the width of the coccolith and is deeper below the rim than in $E$. bollii, in which the central area is only slightly below the rim, and $E$. macellus, where the central area is about at the same level as the very flat rim.

Occurrence: $E$. bollii was found in the lower upper Paleocene (NP5 and NP6) at Site 356, where it occurs together with rare E. macellus and $E$. distichus.

\section{Hayella Gartner, 1969}

(Plates 41, 44, 45)

Hayella situliformis, the only species in Hayella, occurs in the upper Eocene at Site 357, where well-preserved specimens were found. These show that Cyclococcolithella aprica Roth (1973) from the middle Eocene of the Central Pacific (DSDP Site 171) is a basal part of $H$. situliformis, from which the whole distal structure has been removed. On Plate 44 various stages of preservation of $H$. situliformis are shown. Questionable Hayella sp. were also found in the upper Miocene at Site 354 (Plate 41, Figure 10) and in the lower Miocene at Site 356 (Plate 45, Figures 3, 6, 10).

\section{Hornibrookina Edwards, 1973 \\ (Plates 46, 49)}

$H$. australis, $H$. teuriensis, and $H$. edwardsii were encountered in Leg 39 Paleocene samples, but only $H$. teuriensis and $H$. edwardsii, the oldest forms of Hornibrookina, are illustrated on Plate 46.

Hornibrookina was described from the Paleocene of New Zealand and was also found in the Paleocene recovered on DSDP Leg 29 in the southwestern Pacific (Edwards and Perch-Nielsen, 1973) and the Crimea. At Site 356, the first occurrence of $H$. edwardsii was observed at the base of NP3, the $C$. danicus Zone, the first occurrence of $H$. australis at the base of NP6, the H. kleinpellii Zone.

Hornibrookina edwardsii n. sp.

(Plate 46, Figures 2, 3, 5, 6; Plate 49, Figures 40, 41)

Holotype: Plate 46, Figure 6.

Type level: Chiasmolithus danicus Zone (NP3); early Paleocene.

Type locality: São Paulo Plateau, DSDP Site 356.

Diagnosis: An elliptical species of Hornibrookina with a row of knobs protruding between the elements of the distal shield and a wall surrounding the central area.

Description: The distal and the proximal shield consist of about 20 to 30 slightly overlapping elements. Knobs protrude between these elements just outside the wall which surrounds the central area. The small central area is partly filled by radial elements. The proximal shield is simple and smaller than the distal one.

Remarks: $H$. edwardsii usually has a smaller central area than $H$. teuriensis and also differs from this species by the distinct wall and row of knobs. In $H$. teuriensis, the less distinct knobs are part of the wall directly surrounding the central area. In the light microscope, $H$. edwardsii might be mistaken for a form of Biscutum, from which genus the genus Hornibrookina might have evolved.

Occurrence: $H$. edwardsii was only observed in the lower part of the $C$. danicus Zone (early Paleocene) at Site 356.

\section{Ilselithina Stradner, 1966 (Plate 45)}

Ilselithina fusa, described by Roth (1970) from the Oligocene of Alabama was found in the lower Miocene at Site 356 and has also been reported by Edwards and Perch-Nielsen (1973) from the Miocene of the southwestern Pacific.

\section{Lapideacassis Black, 1971a (Plate 49)}

Several new species of the Cretaceous genus Lapideacassis were found in the Paleocene at Sites 354 and 356 (Perch-Nielsen and Franz, this volume). Since this genus occurs very rarely also in the Cretaceous, it seems unlikely, that the specimens found in the Paleocene here should be reworked.

\section{Minylitha Bukry 1973b (Plate 37)}

Minylitha convallis was found in the middle and upper Miocene at Sites 354 and 357 . The SEM picture Plate 37 still gives no indication as to what family this genus could belong to and whether it is a fossil at all.

\section{Nannotetrina Achuthan and Stradner, 1969 (Plate 47)}

Nannotetrina is present in all middle Eocene sequences, but usually heavily overgrown, so that a species identification is impossible in most samples.

\section{Scampanella Forchheimer and Stradner, 1973}

Several new species of the Cretaceous genus Scampanella were found in the Paleocene at Site 356 (Perch-Nielsen and Franz, this volume). Single specimens were also observed in the Upper Cretaceous at Site 357 and in the Kef section in Tunisia. Scampanella is very rare in the samples where it occurs. Although reworked Late Cretaceous coccoliths are found in varying amounts in most Paleocene samples, it seems unlikely that Scampanella, which is very rare only also in the Cretaceous, should be reworked.

\section{ACKNOWLEDGMENTS}

I thank Inge Nyegaard, Copenhagen, and U. Gerber and H.E. Franz, ETH Zürich, for photographic work. H.E. Franz also patiently searched and photographed some of the rare species with the SEM. All SEM work was done in the SEM laboratory of the Swiss Federal Institute of Technology (ETH), Hönggerberg, Zürich, where all negatives are stored. I am grateful to my fellow shipboard scientists for good collaboration on board and during subsequent meetings, and to D. Bukry, U.S. Geological Survey, La Jolla, California for critically reading the manuscript.

\section{REFERENCES}

Achuthan, M.V. and Stradner, H. 1969. Calcareous nannoplankton from the Wemmelian stratotype. In Brönnimann, P. and Renz, H.H. (Eds.), First Internat. Conf. Plankt. Microfossils Proc., Geneva: Leiden (E.J. Brill), v. 1, p. 1-13.

Berger, W.H. and Roth, P.H., 1975. Oceanic micropaleontology: progress and prospect: Rev. Geophys. Space Phys., v. 13, p. 561-635.

Berggren, W.A., 1972. A Cenozoic time-scale-some implications for regional geology and paleobiogeography: Lethaia, v. 5, p. 195-215.

1973. Biostratigraphy and biochronology of the late Miocene (Tortonian and Messinian) of the Mediterranean: Intern. Geodynamics Proj. Symp. on Messinian Events in the Mediterranean, Utrecht. p. 10-20.

Berggren, W.A. and Van Couvering, J.A., 1974. The late Neogene, biostratigraphy, geochronology and paleoclimatology of the last 15 million years in marine and continental sequences: Paleogeogr., Paleoclimatol., Paleoecol., v. 16, p. 1-216.

Black, M., 1971a. Problematical microfossils from the Gault Clay: Geol. Mag., v. 108, p. 325-327.

, 1971b. The systematics of coccoliths in relation to the paleontological record. In Funnel, B.M. and Riedel, W.R., (Eds.), The micropaleontology of oceans: Cambridge (Cambridge University Press), p. 611-624.

Boudreaux, J.E. and Hay, W.W., 1969. Calcareous nannoplankton and biostratigraphy of the late PliocenePleistocene-Recent sediments in the Submarex cores. Rev. Espan. Micropaleontol., v. 1, p. 249-292.

Bramlette, M.N. and Sullivan, F.R., 1973. Coccolithophorids and related nannoplankton of the early Tertiary in California: Micropaleontology, v. 7, p. 129174.

Bukry, D., 1973a. Coccolith and silicoflagellate stratigraphy, Tasman Sea and southwestern Pacific Ocean, Deep Sea Drilling Project Leg 21. In Burns, R.E., Andrews, J.E., et al., Initial Reports of the Deep Sea Drilling Project, 
Volume 21: Washington (U.S. Government Printing Office), p.885-893.

1973b. Coccolith stratigraphy, Eastern Equatorial

Pacific, Leg 16. In van Andel, Tj.H., Heath, G.R., et al., Initial Reports of the Deep Sea Drilling Project, Volume 16: Washington (U.S. Government Printing Office), p. $653-711$

1973c. Low latitude coccolith biostratigraphic zonation. In Edgar, N.T., Saunders, J.B., et al., Initial Reports of the Deep Sea Drilling Project, Volume 15: Washington (U.S. Government Printing Office), p. 685703.

1975. Coccolith and silicoflagellate stratigraphy, Northwestern Pacific Ocean, Deep Sea Drilling Project Leg 32. In Larson, R.L., Moberly, R., et al., Initial Reports of the Deep Sea Drilling Project, Volume 32: Washington (U.S. Government Printing Office), p. 677 701.

Bukry, D. and Bramlette, M.N., 1968. Stratigraphic significance of two genera of Tertiary calcareous nannofossils: Tulane Stud. Geol., v. 6, p. 149-155.

, 1970. Coccolith age determinations Leg 3, Deep Sea Drilling Project. In Maxwell, A.E., von Herzen, R., et al., Initial Reports of the Deep Sea Drilling Project, Volume 3: Washington (U.S. Government Printing Office), p. 589-611.

Bukry, D. and Percival, S.F., 1971. New Tertiary calcareous nannofossils: Tulane Stud. Geol., v. 8, p. 123-146.

Cepek, P. and Hay, W.W., 1969. Calcareous nannoplankton and biostratigraphic subdivision of the Upper Cretaceous: Gulf Coast Assoc. Geol. Soc. Trans., v. 19, p. 323-336. 1970. Zonation of the Upper Cretaceous using calcareous nannoplankton: Paläontol. Abh. Abt. B, Paläobot., v. 3, p. 333-340.

Deflandre, G., 1947. Braarudosphaera nov. gen., type d'une famille nouvelle de Coccolithophoridés actuels à éléments composites: C.R. Acad. Sci. (Paris), v. 225, p. 439-441.

, 1954. Premiers apports de la paléontologie à nos connaissances sur l'évolution des Coccolithophoridés: Rapp. Comm. VIIIe Congr. Int. Bot. Paris, v. 17, p. 119120.

1957. Goniolithus nov. gen., type d'une famille nouvelle de Coccolithophoridés fossiles, à étéments pentagonaux non composites: C.R. Acad. Sci. (Paris), v. 244 , p. $2539-2541$.

Deflandre, G. and Fert, C., 1954. Observations sur les Coccolithophoridés actuels et fossiles en microscopie ordinaire et électronique: Ann. Paléont., v. 40, p. 115176.

Edwards, A.R., 1973. Key species of New Zealand calcareous nannofossils: New Zealand J. Geol. Geophys., v. 16, p. 68-89.

Edwards, A.R. and Perch-Nielsen, K. 1975. Calcareous nannofossils from the southern Southwest Pacific, Deep Sea Drilling Project, Leg 39. In Kennett, J.P., Houtz, R.E., et al., Initial Reports of the Deep Sea Drilling Project, Volume 29: Washington (U.S. Government Printing Office), p. 469-539.

Forchheimer, S. and Stradner, H., 1973. Scampanella, eine neue Gattung kretazischer Nannofossilien: Verh. Geol. B.A. Wien, p. 285-289.

Fütterer, D., 1976. Kalkige Dinoflagellaten (Calciodinelloideae) und die systematische Stellung der Thoracosphaeroideae: N. Jb. Geol. Palăont. Abh., v. 151, p. 119 141.

Gartner, S., 1967. Calcareous nannofossils from Neogene of Trinidad, Jamaica and Gulf of Mexico: Kansas Univ. Paleontol. Contr. Paper 29.

1969. Two new calcareous nannofossils from the Gulf Coast Eocene: Micropaleontology, v. 15, p. 31-34.
1973. Absolute chronology of the late Neogene calcareous nannofossil succession in the equatorial Pacific: Geol. Soc. Am. Bull., v. 84, p. 2021-2034.

Gartner, S. and Bukry, D. 1974. Ceratolithus acutus Gartner and Bukry n. sp. and Ceratolithus amplificus Bukry and Percival-nomenclatural clarification: Tulane Stud. Geol., v. 11, p. $115-118$.

1975. Morphology and phylogeny of the coccolithophycean family Ceratolithaceae: J. Res. USGS, v. 3 , p. $451-465$.

Haq, B.U., 1967. Calcareous nannoplankton from the Lower Eocene of the Zinda Pir, District Dera Ghazi Khan: West Pakistan. Geol. Bull. Panjab Univ., v. 6, p. 55-83.

1973. Evolutionary trends in the Cenozoic coccolithophore genus Helicopontosphaera: Micropaleontology, v. 19 , p. $32-52$.

Haq, B.U. and Lohmann, G.P., 1975 (preprint). Early Cenozoic calcareous nannoplankton biogeography of the Atlantic Ocean: Tech. Rept. WHOI 75-45.

Hay, W.W., 1972. Probabilistic stratigraphy: Eclog. Geol. Helv., v. 65 , p. 255-266.

Hay, W.W. and Mohler, H.P., 1967. Calcareous nannoplankton from early Tertiary rocks at Pont Labau, France, and Paleocene-early Eocene correlations: J. Paleontol., v. 41 , p. $1505-1541$.

Hay, W.W., Mohler, H.P., Roth, P.H., Schmidt, R.R., and Boudreaux, J.E., 1967. Calcareous nannoplankton zonation of the Gulf Coast and Caribbean-Antillean area and transoceanic correlation: Gulf Coast Assoc. Geol. Soc. Trans., v. 17 , p. 428-480.

Kamptner, E., 1927. Beitrag zur Kenntnis adriatischer Coccolithophoriden: Arch. Protistenk., v. 58, p. 173-184. 1928. Uber das System und die Phylogenie der Kalkflagellaten: Arch. Protistenk., v. 64, p. 19-43.

Lemmermann, E., 1908. Flagellatae, Chlorophyceae, Coccosphaerales und Silicoflagellatae. In Brandt, K. and Apstein, C. (Eds.), Nordisches Plankton. Botanischer Teil: Kiel and Leipzig (Lipsius \& Tischer).

Lipps, J.H., 1969. Triquetrorhabdulus and similar calcareous nannoplankton: J. Paleontol., v. 43, p. 1029-1032.

Martini, E., 1969. Nannoplankton aus dem Latdorf (locus typicus) und weltweite Parallelisierungen im oberen Eozän und unteren Oligozän: Senckenb. Letheae, v. 50, p. 117159.

1971. Standard Tertiary and Quaternary calcareous nannoplankton zonation. In Farinacci, A. (Ed.), Plankt. Conf. Second, Rome 1970, Proc.: Roma (Tecnoscienza), v. 2, p. 739-785.

1976. Cretaceous to Recent calcareous nannoplankton from the Central Pacific Ocean (DSDP Leg 33). In Jackson, E.D., Schlanger, S.O., et al., Initial Reports of the Deep Sea Drilling Project, Volume 33: Washington (U.S. Government Printing Office), p. 383-423.

Maxwell, A.E., von Herzen, R., et al., 1970. Initial Reports of the Deep Sea Drilling Project, Volume 3: Washington (U.S. Government Pringing Office).

Müller, C., 1974. Calcareous nannoplankton Leg 25 (Western Indian Ocean). In Simpson, E.S.W., Schlich, R., et al., Initial Reports of the Deep Sea Drilling Project, Volume 25: Washington (U.S. Government Printing Office), p. $579-633$.

Norris, R.E., 1965. Living cells of Ceratolithus cristatus (Coccolithophorineae): Arch. Protistenk., v. 108, p. 1924.

Perch-Nielsen, K. 1969. Die Coccolithen einiger dänischer Maastrichtien-und Danienlokalitäten: Meddel. Dansk. Geol. For, v. 19, p. 51-68.

1971a. Durchsicht Tertiärer Coccolithen. In Farinacci, A. (Ed.), Plankt. Conf. Second Rome 1970 Proc.: Roma (Tecnoscienza), v. 2, p. 939-980. 
1971b. Einige neuen Coccolithen aus dem Paleozän von Dänemark, der Bucht von Biskaya und dem Eozän der Labrador See: Geol. Soc. Denmark, Bull., v. 21, p. 51-66.

, 1971c. Elektronenmikroskopische Untersuchungen an Coccolithen und verwandten Formen aus dem Eozän von Dänemark: K. Dansk Vid. Selsk. Biol. Skr., v. 18.

1972. Remarks on Late Cretaceous to Pleistocene coccoliths from the North Atlantic. In Berggren, W.A., Laughton, A.S., et al., Initial Reports of the Deep Sea Drilling Project, Volume 12: Washington (U.S. Government Printing Office), p. 1003-1069.

1973. Neue Coccolithen aus dem Maastrichtien von Dänemark, Madagaskar und Aegypten: Geol. Soc. Denmark, Bull., v. 21, p. 306-333.

Rade, J., 1975. Scyphosphaera evolutionary trends with special reference to eastern Australia: Micropaleontology, v. 21, p. $151-164$.

Roth, P.H., 1970. Oligocene calcareous nannoplankton biostratigraphy: Eclog. Geol. Helv., v. 63, p. 799-881.

1973. Calcareous nannofossils-Leg 17, Deep Sea Drilling Project. In Winterer, E.L., Ewing, J.I., et al., Initial Reports of the Deep Sea Drilling Project, Volume 17: Washington (U.S. Government Printing Office), p. $695-795$.

1974. Calcareous nannofossils from the northwestern Indian Ocean, Leg 24, Deep Sea Drilling Project. In Fisher, R.L., Bunce, E.T., et al., Initial Reports of the Deep Sea Drilling Project, Volume 24: Washington (U.S. Government Printing Office), p. 969-994.

Roth, P.H. and Thierstein, H., 1972. Calcareous nannoplankton: Leg 14 of the Deep Sea Drilling Project. In Hayes, D.E., Pimm, A.C., et al., Initial Reports of the Deep Sea Drilling Project, Volume 14: Washington (U.S. Government Printing Office), p. 421-485.

Schiller, J., 1930. Coccolithineae. In Dr. Rabenhorst's Kryptogamenflora von Deutschland, Osterreich und der Schweiz: Leipzig, p. 89-267.
Stradner, H., 1961. Vorkommen von Nannofossilien im Mesozoikum und Alttertiär: Erdölz, v. 75, p. 472-488. 1963. New contributions to Mesozoic stratigraphy by means of nannofossils: Sixth World Congr. Proc. (Franfurt, 1963); sect. 1.

Takayama, T., 1972. A note on the distribution of Braarudosphaera bigelowi (Graan and Braarud) Deflandre in the bottom sediments of Sendai Bay: Japan. Paleont. Soc. Japan, Trans. Proc. N.S. 87, p. 429-435.

Thierstein, H., in press. Biostratigraphy of marine Mesozoic sediments by calcareous nannoplankton: Plankt. Conf. Third Proc. See fig. 12 in Berger and Roth, 1975.

Troelsen, J.C. and Quadros, L.P., 1971. Distribuicao Bioestratigrafica dos Nanofosseis em Sedimentos Marinhos (Aptiano-Mioceno) do Brasil: Ann. Acad. Brasil. Cienc., v. 43 , p. $577-609$.

Van Hinte, J.E., 1976. A Cretaceous time scale: Am. Assoc. Petrol. Geol. Bull., v. 60, p. 498-516.

Verbeek, J.W., 1976. Upper Cretaceous calcareous nannoplankton zonation in a composite section near El Kef, Tunisia. I \& II: Koninkl. Nederl. Akad. Wetens. Amsterdam, Proc. B, v. 79, p. 129-148.

Wind, F. and Wise, S.W., in press. Leg 36 coccoliths. In Barker, P., Dalziel, I.W.D., et al., Initial Reports of the Deep Sea Drilling Project, Volume 36: Washington (U.S. Government Printing Office).

Worsley, T.R., 1974. The Cretaceous-Tertiary boundary event in the Ocean. Studies in Paleo-oceanography. In Hay, W.W. (Ed.), Soc. Econ. Pal. Min. Spec. Publ., v. 20, p. 94-125.

Worsley, T.R. and Jorgens, M.L., 1974. Oligocene calcareous nannofossil provinces. Studies in Paleo-oceanography, In Hay, W.W., (Ed.), Soc. Econ. Pal. Min. Spec. Publ., v. 20, p. $85-108$.

Worsley, T.R. and Martini, E., 1970. Late Maestrichtian nannoplankton provinces: Nature, v. 225, p. 1242-1243. 


\section{PLATE 1}

Calcareous nannofossils from Samples 354-5, CC (Figures 1-6); 356-2, CC (Figures 7, 8, 10-12); 354-6-2, $115 \mathrm{~cm}$ (Figure 9).

Magnification 4700× (Figures 1, 7-12); 6800× (Figure 2); 4000× (Figures 3, 6); 5400× (Figure 4); 6100 $\times$ (Figure 5).

Figures 1?,2 Amaurolithus amplificus Bukry and Percival.

Figures 3, 5, 6 Amaurolithus primus (Bukry and Percival) Gartner and Bukry.

Figure 4 Amaurolithus ninae n. sp.

Figures 7, 8, Ceratolithus rugosus Bukry and Bramlette. $10-12$

Figure 9 Amaurolithus delicatus Gartner and Bukry.

(see page 754)

\section{PLATE 2}

Calcareous nannofossils from Samples 354-5-2, $69 \mathrm{~cm}$ (Figures 1, 2, 4, 5, 7) and 354-5, CC (Figures 3, 6, 8-14).

Magnification $6800 \times$ (Figures 1, 2, 10, 12); 4000× (Figures 3, 6); $5400 \times$ (Figure 4); 4700 $\times$ (Figures 5, 7, 11, 13); $6100 \times$ (Figures 8, 9, 14).

Figures 1, 2, 4, Amaurolithus delicatus Gartner and Bukry. $7,10,12$

Figures 3, 5,6 Amaurolithus amplificus (Bukry and Percival) $8,11,13 \quad$ Gartner and Bukry.

Figures 9, 14 Amaurolithus ninae n. sp.

PLATE 3

Calcareous nannofossils from Sample 354-4, CC.

Magnification $3400 \times$ (Figures 1, 2, 4-12, 14); $2000 \times$ (Figure 3); 4000 $\times$ (Figure 13).

Figures 1-14 Ceratolithus atlanticus n. sp. Holotype: Figures 2, 5 
PLATE 1
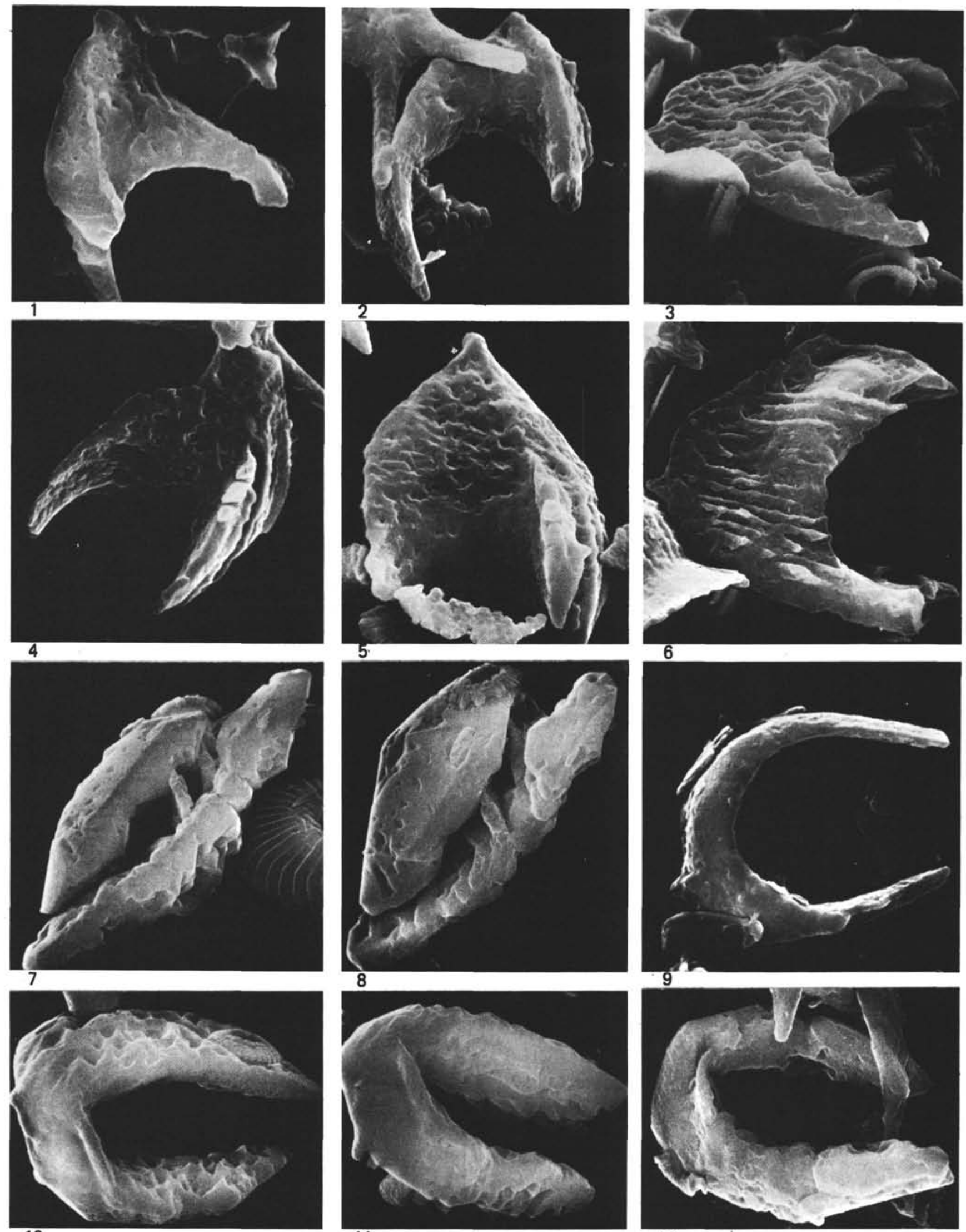
PLATE 2
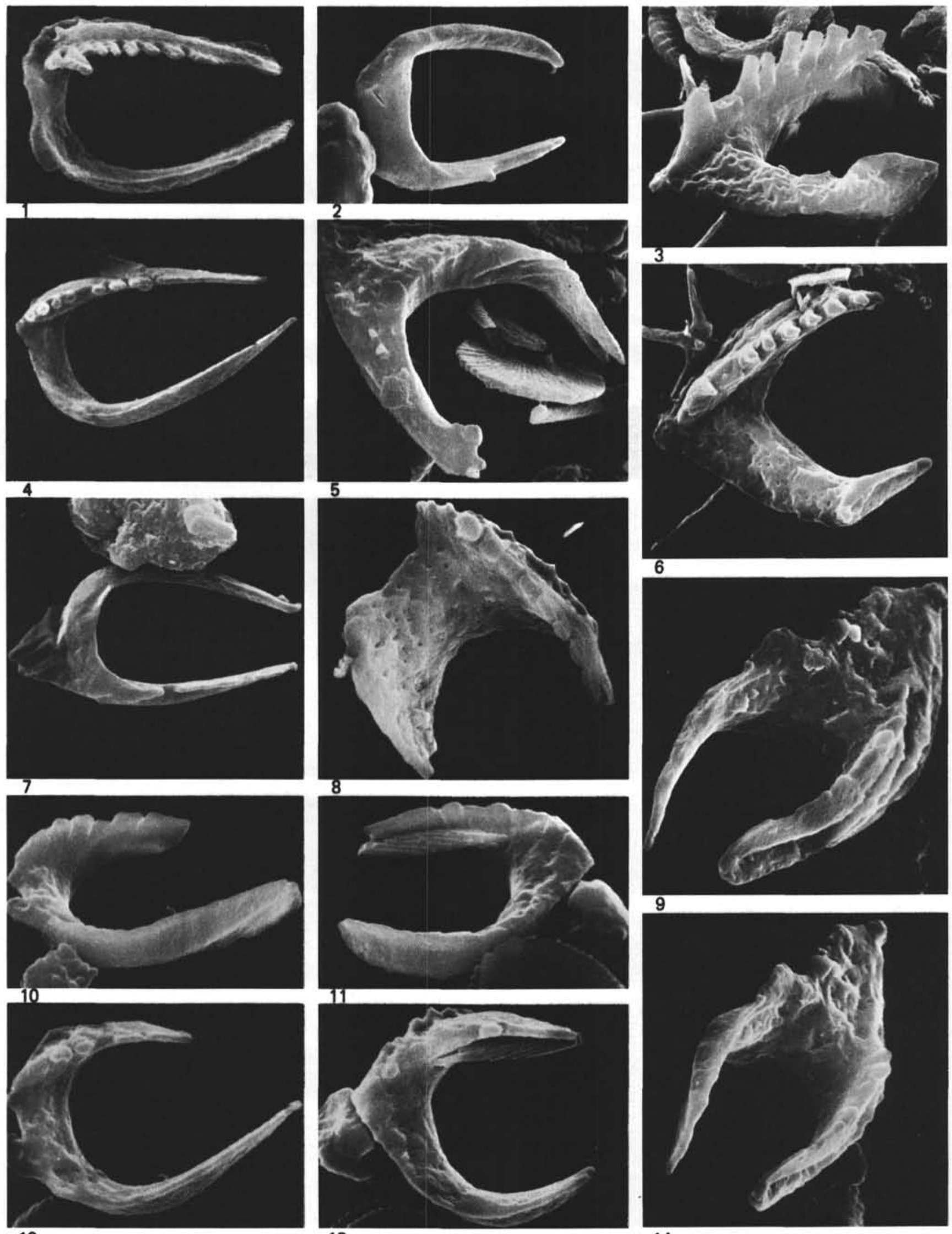


\section{PLATE 3}
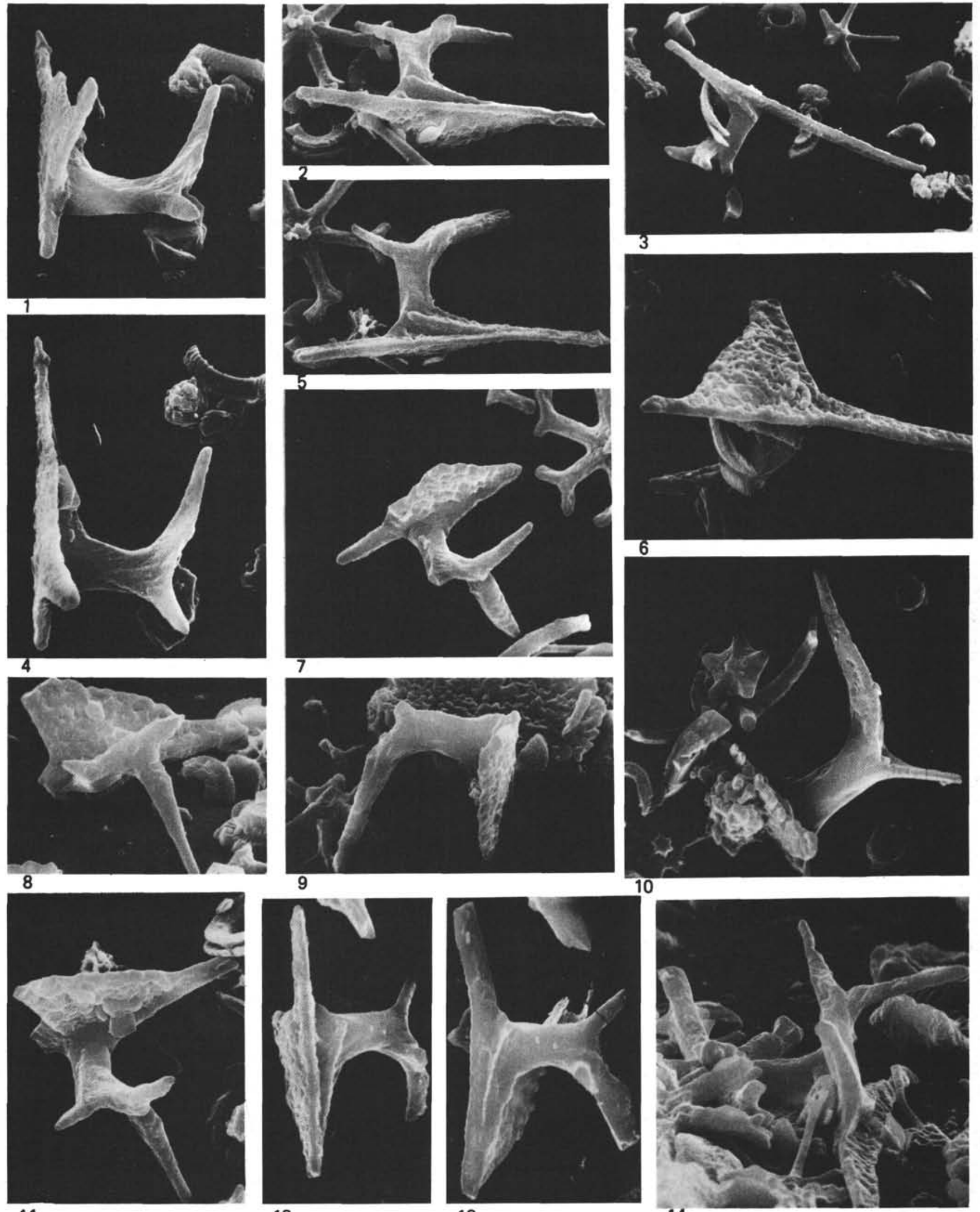

13

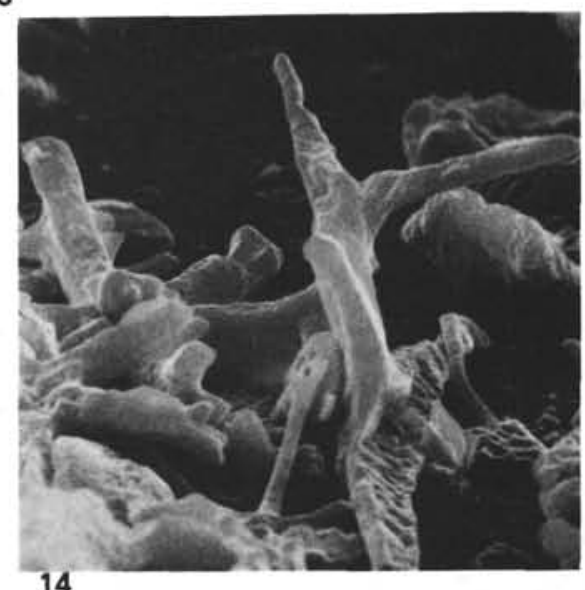




\section{PLATE 4}

Calcareous nannofossils from Sample 354-4-6, $120 \mathrm{~cm}$.

(Figures 1, 2, 4, 5) and Sample 354-4, CC (Figures 3, 6-15).

Magnification $5400 \times$ (Figures 1, 2, 5, 14); 6800×

(Figures 3, 6, 7, 9, 11-13, 15), 6000× (Figures 4, 8);

$4000 \times$ (Figure 10).

Figures 1, 2, 4, Amaurolithus delicatus Gartner and Bukry.

5

Figures 3, 6-15 Amaurolithus ninae n. sp.

(see page 758)

PLATE 5

Calcareous nannofossils from Sample 354-4-6, $76 \mathrm{~cm}$.

Magnification 3400× (Figures 1-5, 7, 10, 11); $4000 \times$ (Figure 6); 6800× (Figures 9, 12); $5400 \times$ (Figures 13, 14).

Figures 1-7, 10 Ceratolithus atlanticus n. sp.

Figures 8,11 Amaurolithus cf. A. tricorniculatus (Gartner) Gartner and Bukry.

Figures 9, 12-14 Amaurolithus ninae n. sp.

(see page 759)

\section{PLATE 6}

Calcareous nannofossils from Sample $354-4-5,20 \mathrm{~cm}$.

Magnification $5400 \times$ (Figures 1, 4, 7); 6800×

(Figures 2, 3, 5, 6, 8-13).

Figures 1, 4,7 Amaurolithus tricorniculatus (Gartner) Gartner 11 and Bukry.

Figures 2, 3, 5, Ceratolithus armatus Müller. $6,9-13$

Figure $8 \quad$ Amaurolithus delicatus Gartner and Bukry.

(see page 760) 
PLATE 4
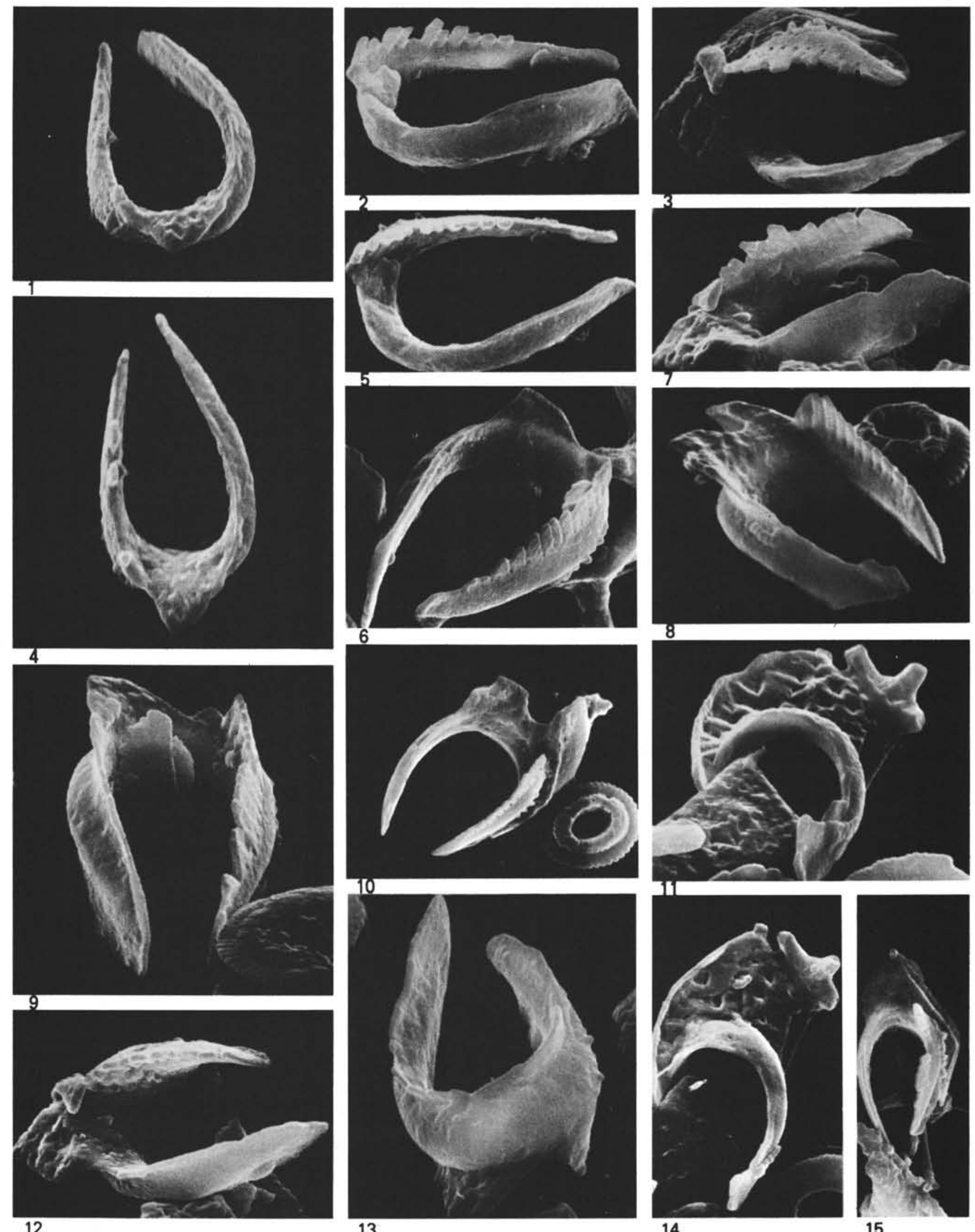
ALBIAN TO PLEISTOCENE CALCAREOUS NA NNOFOSSILS

PLATE 5
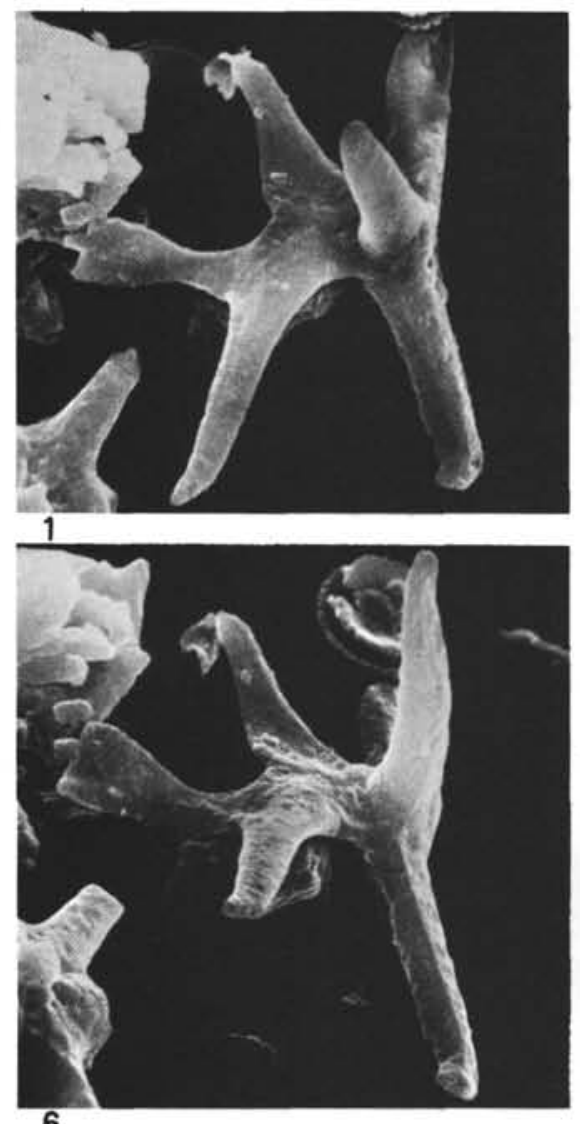

6

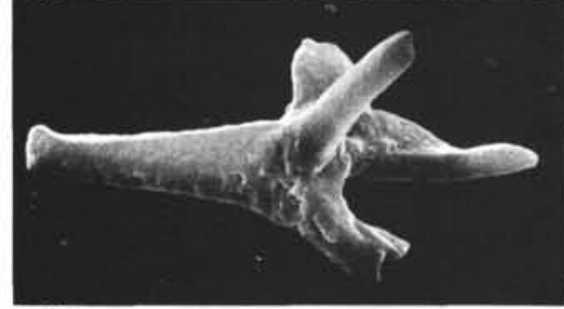

7
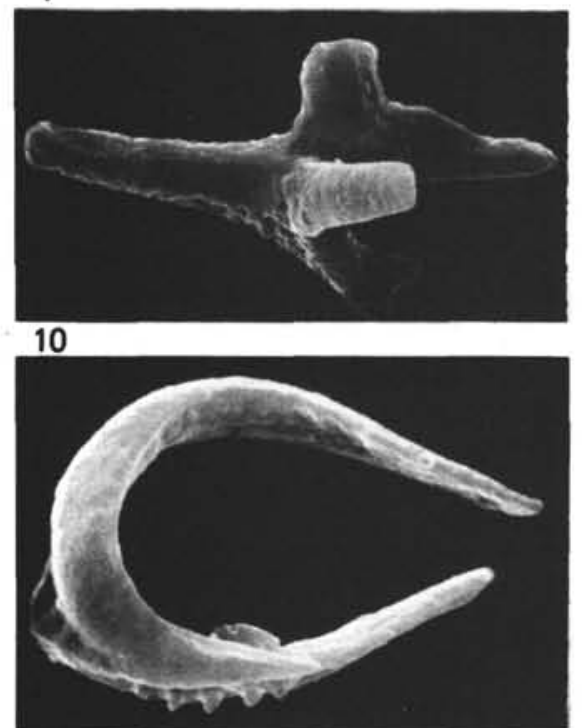

13

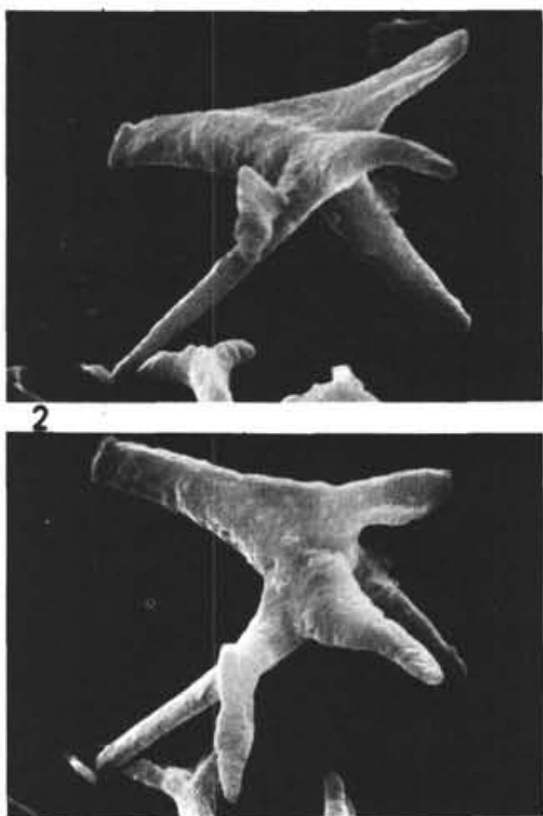

3

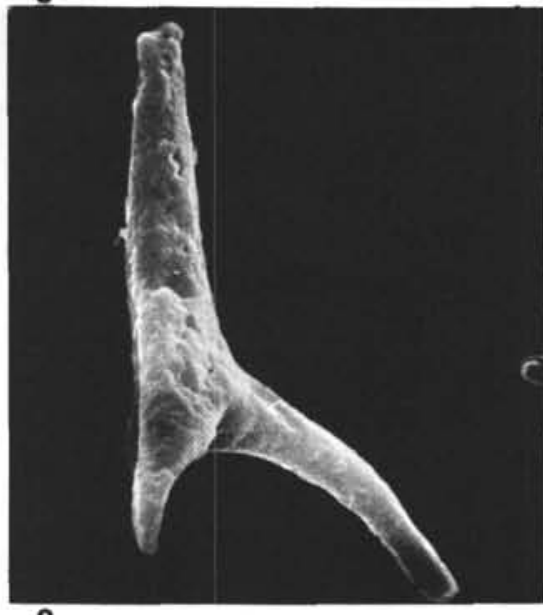

8
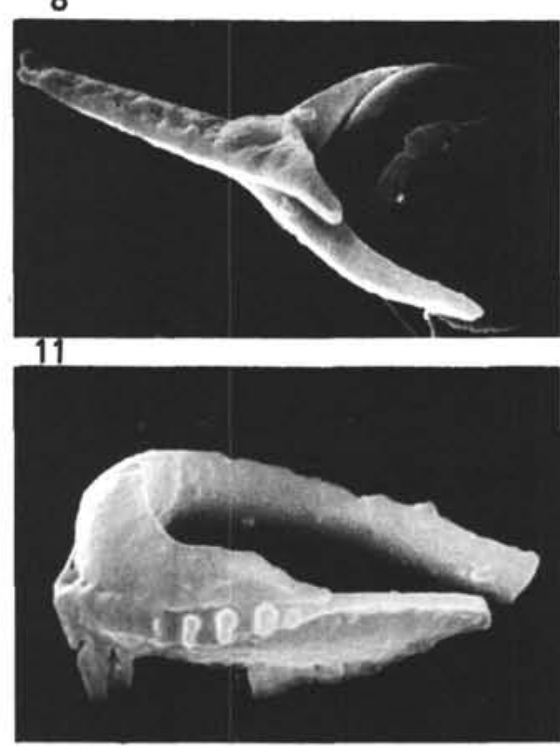

14
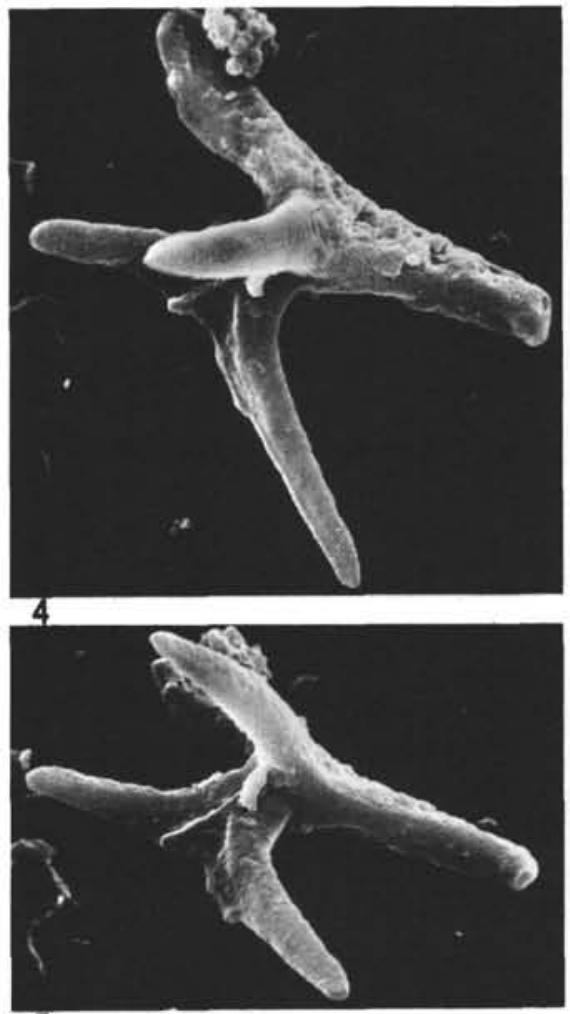

5

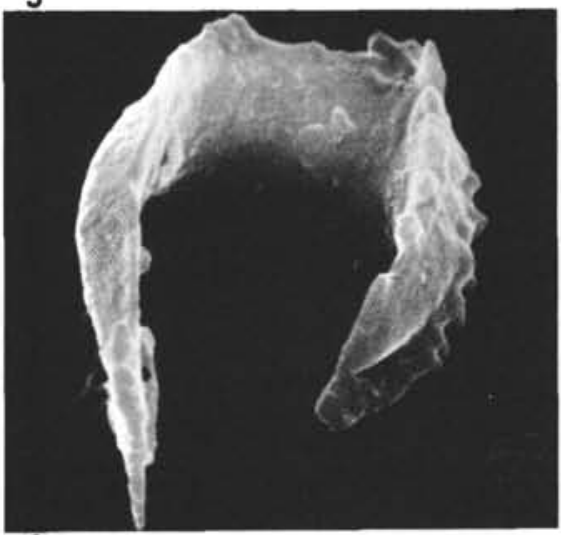

9

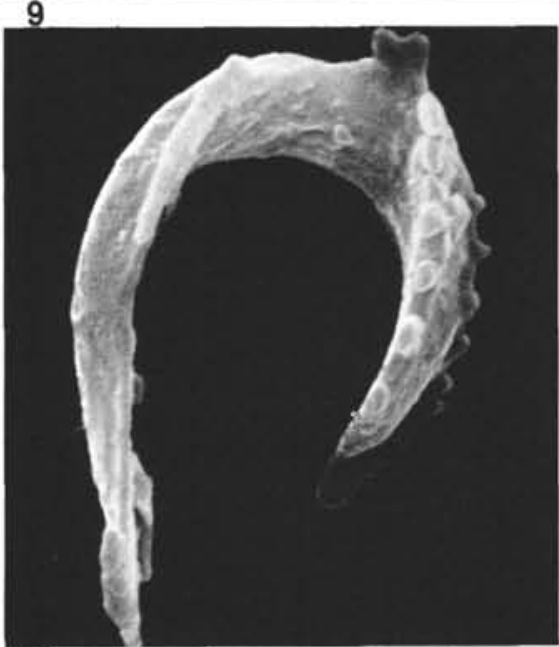

12 
PLATE 6
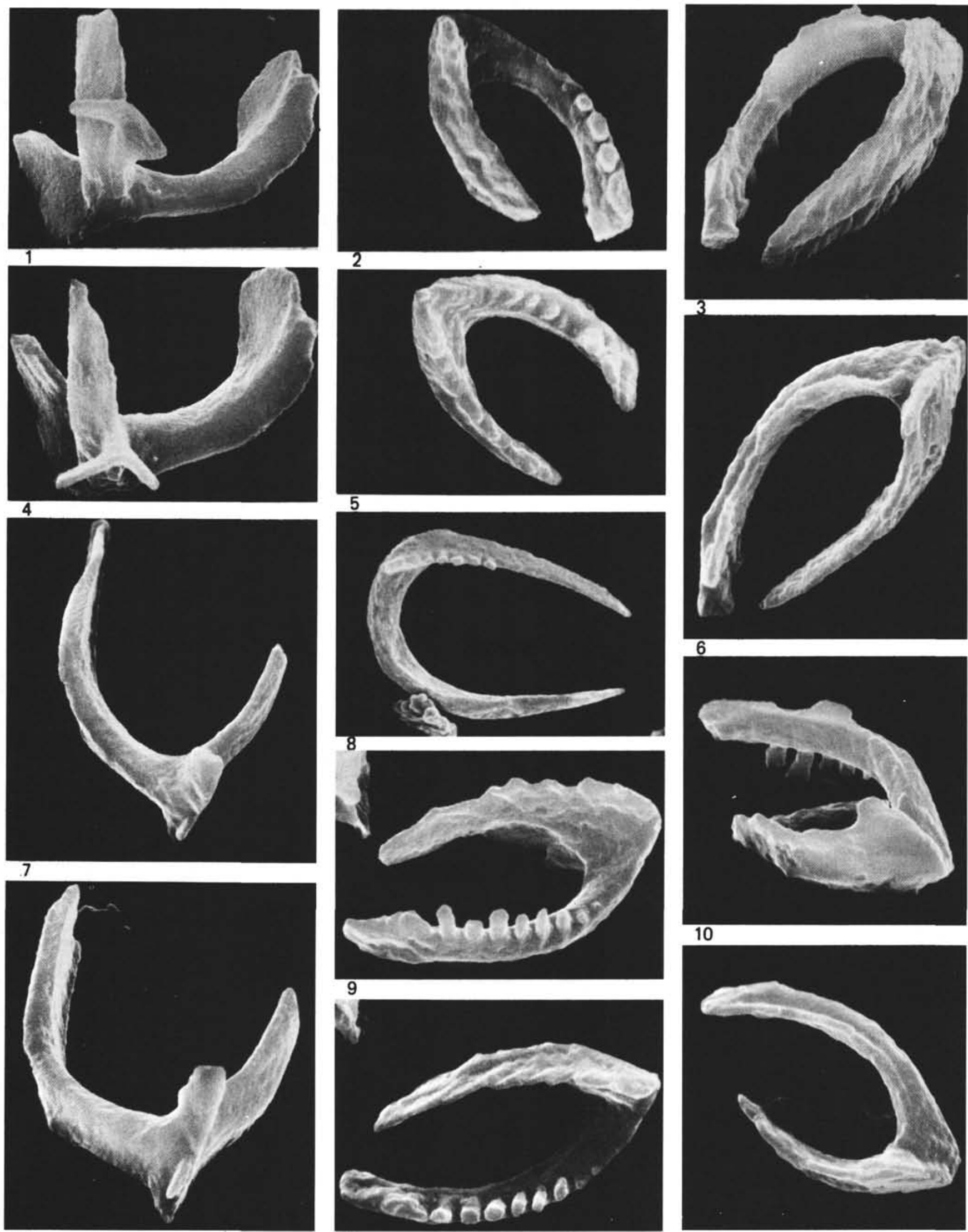


\section{PLATE 7}

Calcareous nannofossils from Sample 354-4-3, $20 \mathrm{~cm}$.

Magnification $5400 \times$ (Figures 1, 2, 7, 10, 13); $6800 \times$ (Figures 3, 5, 8, 9, 11); 4700× (Figures 4, 6, 12).

Figures 1,2,4, Ceratolithus armatus Müller. $6,7,9,10,12$, 13

Figures 3, 5, 8, Amaurolithus ninae $\mathrm{n} . \mathrm{sp}$. 11

(see page 762)

\section{PLATE 8}

Calcareous nannofossils from Sample 354-4-3, $20 \mathrm{~cm}$.

Magnification $5400 \times$ (Figures 1, 4, 7, 11) 4000× (Figures 2, 5); 4700× (Figures 3, 8, 12); $3400 \times$ (Figures 6, 9, 10, 13).

$\underset{7-13}{\operatorname{Figures~1,4,~}} \quad \begin{aligned} & \text { Amaurolithus tricorniculatus (Gartner) Gartner } \\ & \text { and Bukry. }\end{aligned}$

Figures 2, 3,5, Amaurolithus bizzarus (Bukry) Gartner and 6 Bukry.

\section{PLATE 9}

Calcareous nannofossils from Sample 354-4-1, $120 \mathrm{~cm}$.

Magnification $5200 \times$ (Figures 1, 4), 4600 $\times$ (Figures $2,5,7,8) ; 6500 \times$ (Figures 3, 6, 9-12)

Figures 1,4,9 Amaurolithus tricorniculatus (Gartner) Gartner 12 and Bukry.

Figures 2, 3, 5, Ceratolithus armatus Müller. $6,8,11$

Figures 7, 10 Ceratolithus rugosus Bukry and Bramlette. 


\section{PLATE 7}
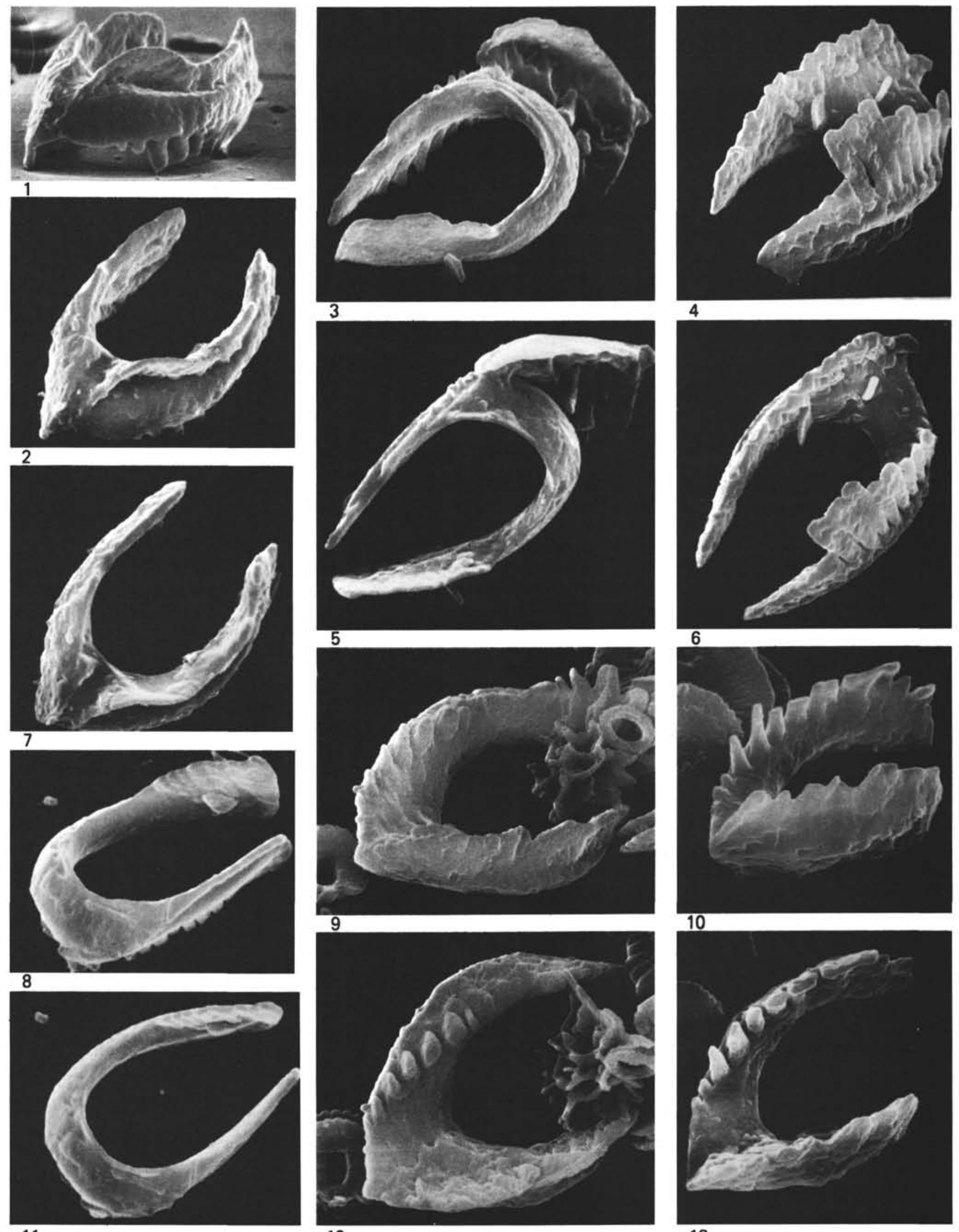


\section{PLATE 8}
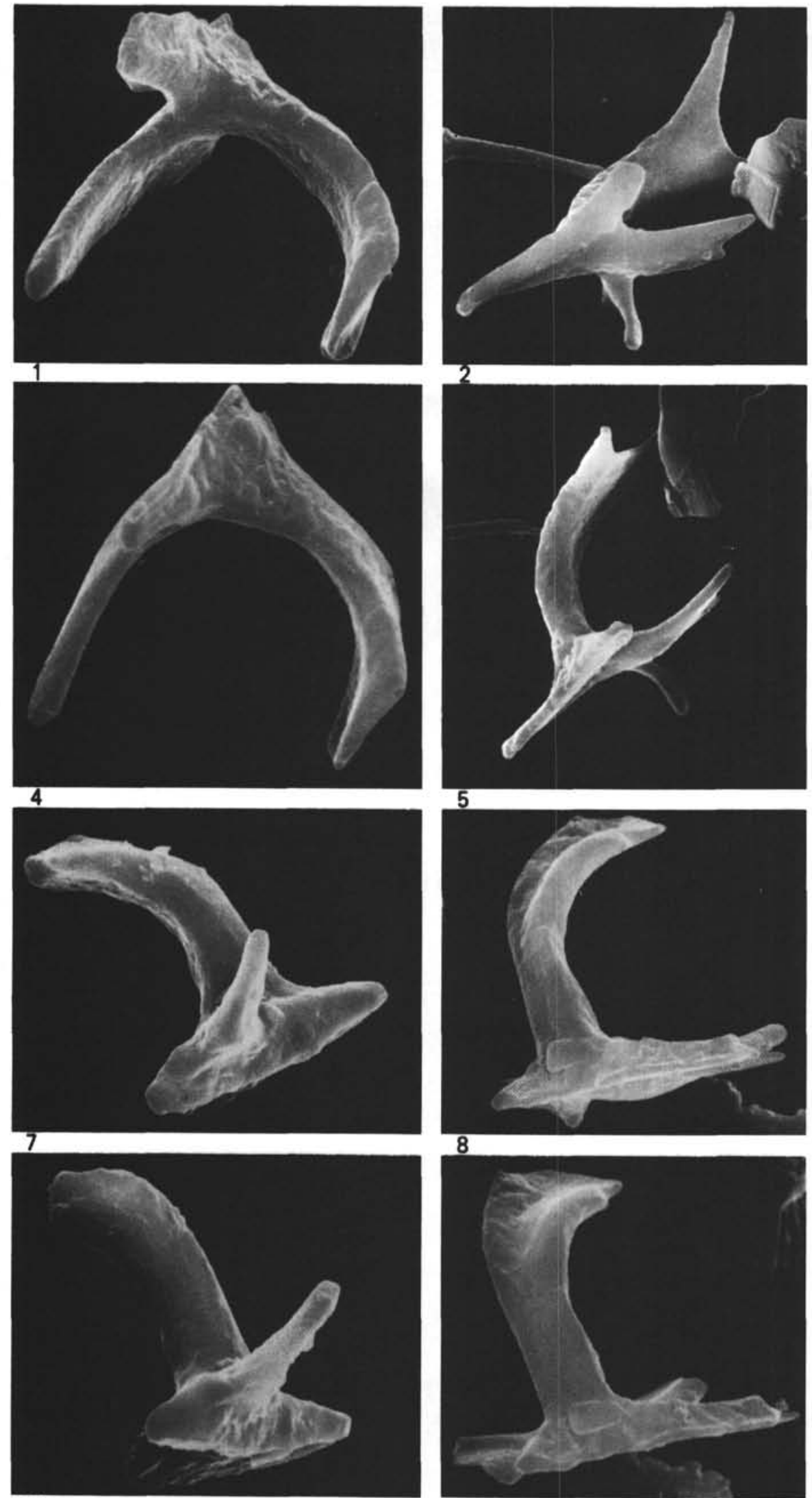

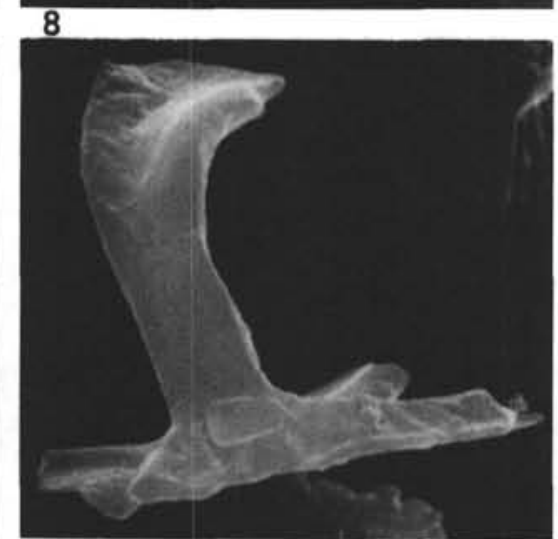

12
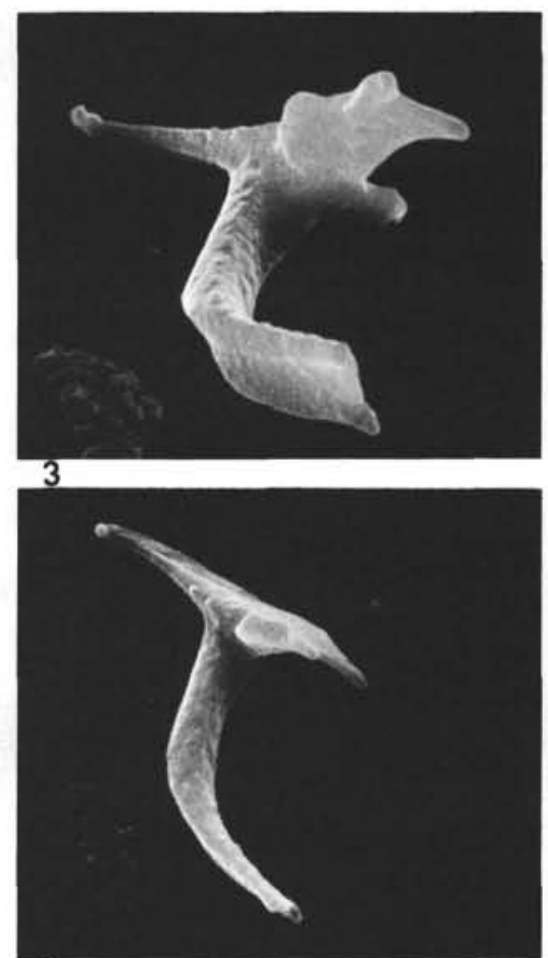

6

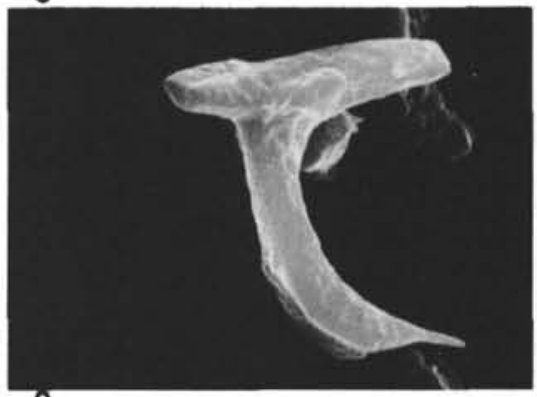

9

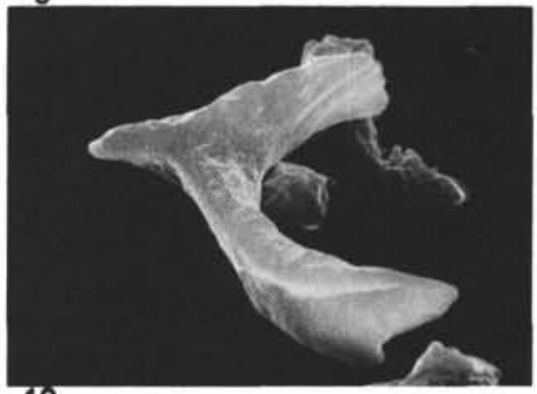

10

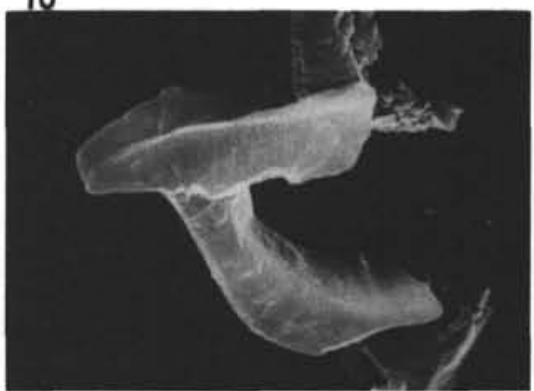

13 
PLATE 9
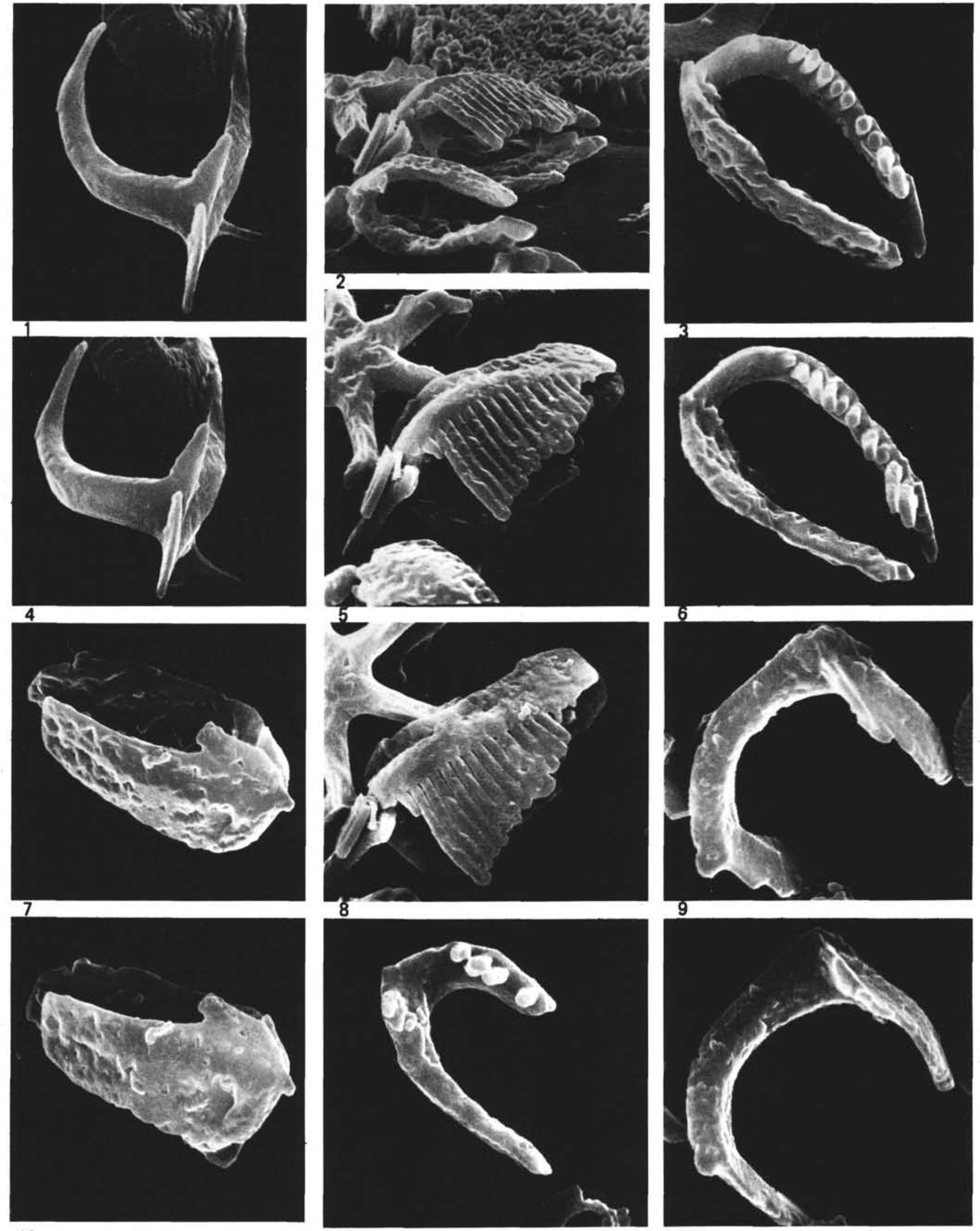


\section{PLATE 10}

Calcareous nannofossils from Samples $357-3-2,135 \mathrm{~cm}$

(Figures 1-5); 354-16-6, $40 \mathrm{~cm}$ (Figures 6-16);

354-16-6 $70 \mathrm{~cm}$ (Figures 17, 22); 354-16-6, $100 \mathrm{~cm}$

(Figures 18, 20); 354-16, CC (Figure 19); 354-16-6, $130 \mathrm{~cm}$

(Figure 21); 354-16-6, $90 \mathrm{~cm}$ (Figure 23).

Magnification 8000× (Figures 1, 2, 10, 11, 15);

$7000 \times$ (Figures 3, 19); 5000 $\times$ (Figures 4, 5);

$7500 \times$ (Figures 6, 18); 10,000 $\times$ (Figures 7, 8, 9, 12, 13,

16, 17, 21-23); 9000× (Figure 14); 6000× (Figure 20).

Figures 1,2 Amaurolithus delicatus Gartner and Bukry.

Figure 3 Amaurolithus primus (Bukry and Percival) Gartner and Bukry.

Figures 4,5 Amaurolithus amplificus (Bukry and Percival) Gartner and Bukry.

Figures 6,7-16 Discoasteroides megastypus Bramlette and Sullivan.

Figure 17 Sphenolithus primus Perch-Nielsen.

Figures 18-20 Fasciculithus ulii Perch-Nielsen.

Figure $21 \quad$ Fasciculithus? sp. or Sphenolithus? sp. This nannolith seems to be a form between the two genera.

Figures 22, 23 Fasciculithus tympaniformis $\mathrm{Hay}$ and Mohler.

(see page 766 )

PLATE 11

Calcareous nannofossils from Samples $356-23-2,70 \mathrm{~cm}$

(Figures 1-3) and 356-25-5, $70 \mathrm{~cm}$ (Figures 4-12).

Magnification $5400 \times$ (Figure 1); 6800× (Figures 2, 3); $4700 \times$ (Figures 4-12).

Figures 1-3 Fasciculithus ulii Perch-Nielsen.

Figures 4-12 Fasciculithus magnus Bukry and Percival.

(see page 767)

PLATE 12

Calcareous nannofossils from Sample 356-23-2, $70 \mathrm{~cm}$.

Magnification 14,000× (Figure 1); 7000× (Figures 2-18).

Figure $1 \quad$ Bomolithus elegans Roth.

Figures 2-5, Fasciculithus janii Perch-Nielsen. $8-18$

Figures 6,7 Sphenolithus primus Perch-Nielsen. 
PLATE 10

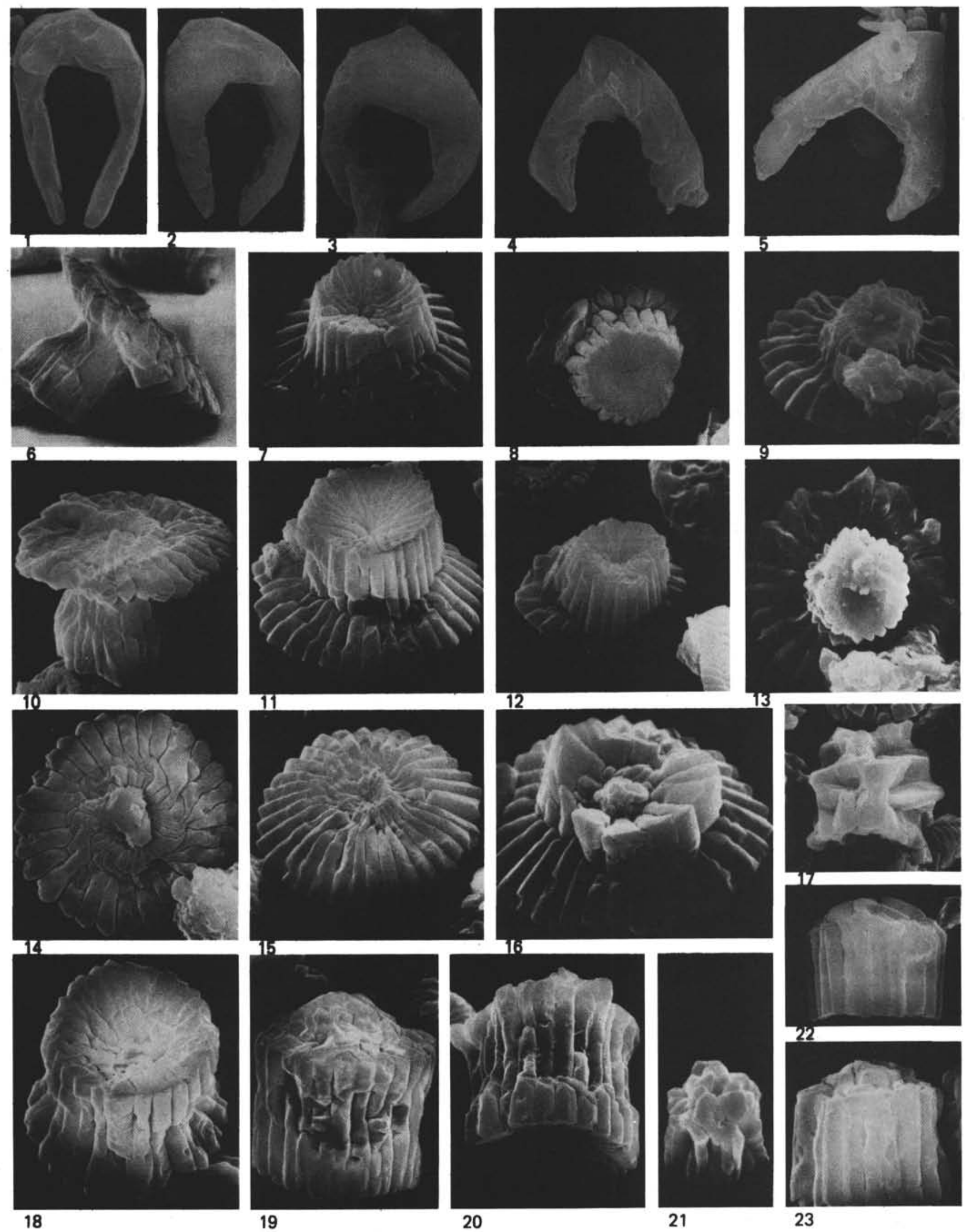


PLATE 11
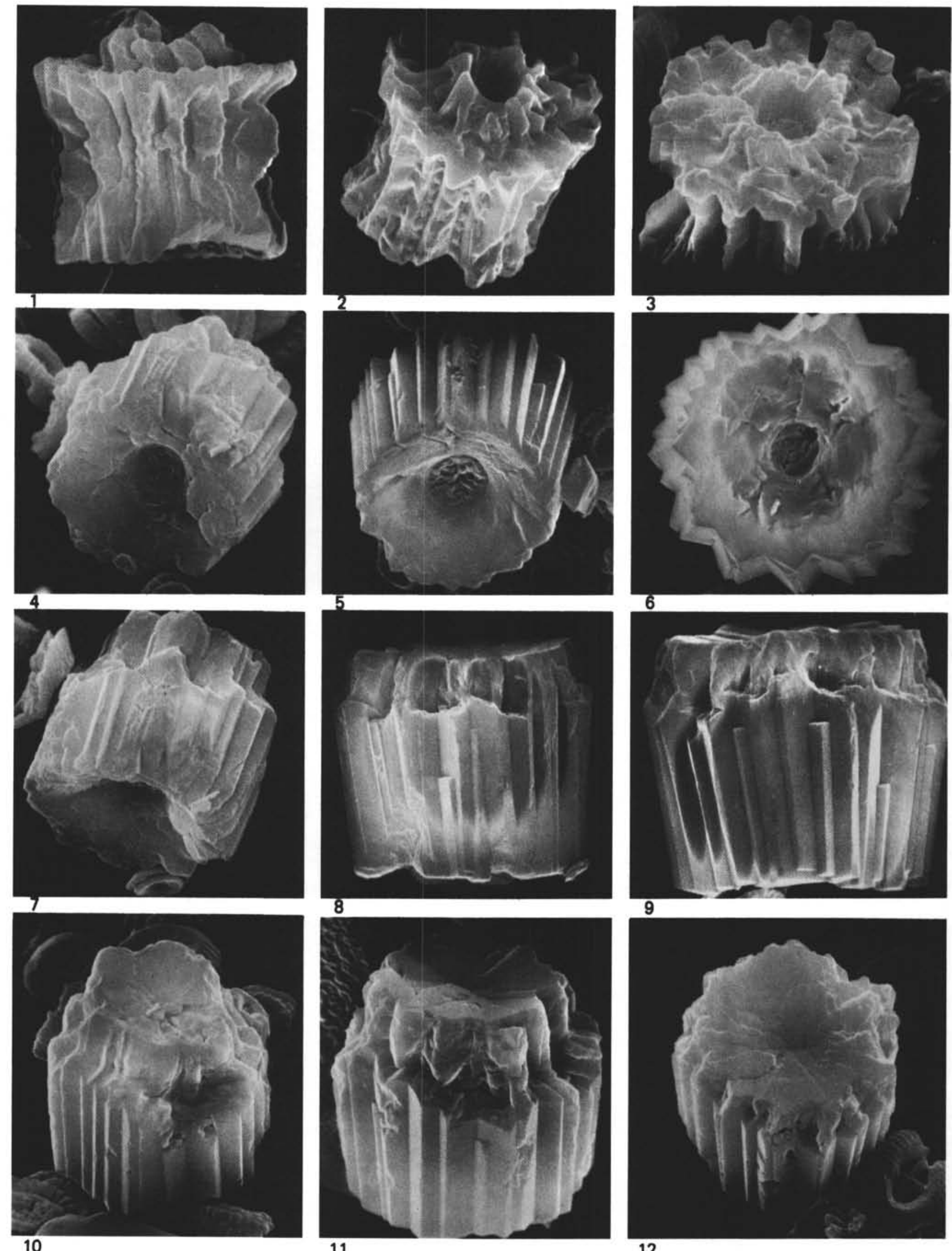
PLATE 12

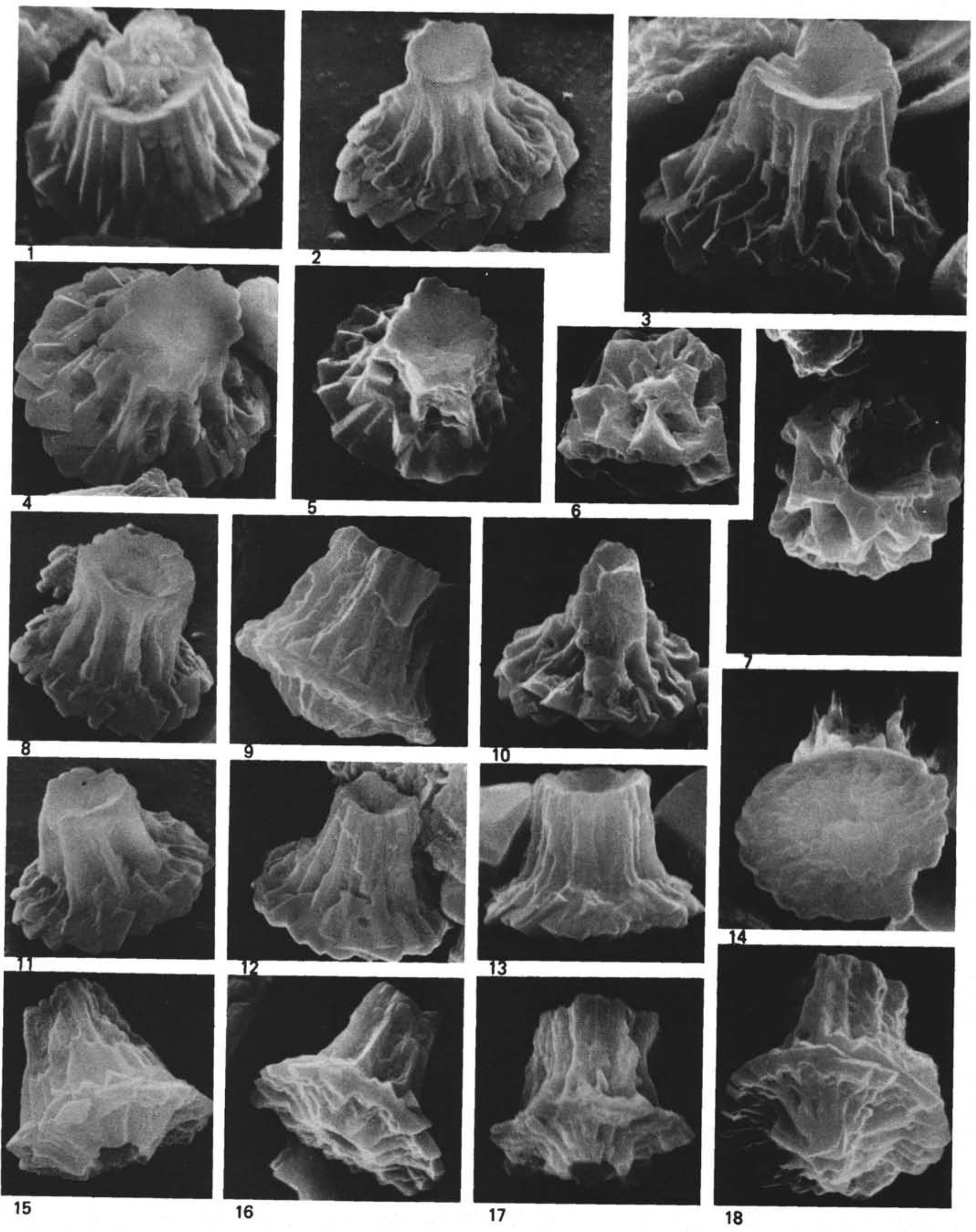


PLATE 13

Calcareous nannofossils from Samples 354-16-6, $70 \mathrm{~cm}$

(Figures 1-4); 354-16-6, $90 \mathrm{~cm}$ (Figures 5, 8);

$354-16-6,100 \mathrm{~cm}$ (Figures 6, 7); 354-16-6, $120 \mathrm{~cm}$

(Figures 9-13, 15, 18); 354-16-6, $130 \mathrm{~cm}$ (Figures 14, 16, 17, 20).

Magnification 5000× (Figures 1, 2, 4-7, 9, 11, 12, 14, 15, 20);

$3500 \times$ (Figure 3); 4500× (Figures 8, 10); 4200×

(Figure 13); 4000× (Figures 16, 17, 19); 4800× (Figure 18).

Figures 1, 2 Discoaster mediosus Bramlette and Sullivan.

Figures 3, 4, 8 Discoaster mohleri Bukry and Percival.

Figure 5 Heliolithus? conicus Perch-Nielsen.

Figures 6,7 Discoasteroides bramlettei Bukry and Percival.

Figures 9, 13, 17 Heliolithus? cantabriae Perch-Nielsen; specimens with high (Figure 9) and low (Figure 13) proximal column.

Figure $10 \quad$ Discoasteroides $\mathrm{sp}$.

Figures 11, 12, Markalius variabilis n. sp. Figure 20: Holotype. $15,16,18-20$

Figure 14 Discoasteroides megastypus (?) Bramlette and Sullivan.

(see page 770)

PLATE 14

Calcareous nannofossils from Samples 354-6-1, $99 \mathrm{~cm}$

(Figure 1); 357-26-4, $48 \mathrm{~cm}$ (Figure 2); 354-14-1, $55 \mathrm{~cm}$

(Figures 3, 5); 356-7-3, $70 \mathrm{~cm}$ (Figures 4, 6)

357-23-6, $66 \mathrm{~cm}$ (Figure 7); 356-10-1, $110 \mathrm{~cm}$ (Figures 8, 9); 356-9-2, $70 \mathrm{~cm}$ (Figure 10); 356-10-4, $70 \mathrm{~cm}$ (Figure 11); $356-10-1,110 \mathrm{~cm}$ (Figures 12, 13).

Magnification $3250 \times$ (Figures 1, 4, 5, 7);

$6500 \times$ (Figures 2, 6, 8-10); 5250× (Figures 11-13).

Figure $1 \quad$ Discoaster mirus Deflandre.

Figures 2, 8, 9 Discoaster bifax Bukry.

Figure 3 Pedinocyclus larvalis (Bukry and Bramlette) Loeblich and Tappan.

Figure 4 Discoaster gemmifer Stradner.

Figure 5 Discoaster sp.

Figure 6 Discoaster wemmelensis Achutan and Stradner.

Figure $7 \quad$ Tribrachiatus orthostylus Shamrai.

Figures 10,13 Discoaster septemradiatus (Klumpp) Martini.

Figures 11, 12 Discoaster sublodoensis Bramlette and Sullivan. 
PLATE 13
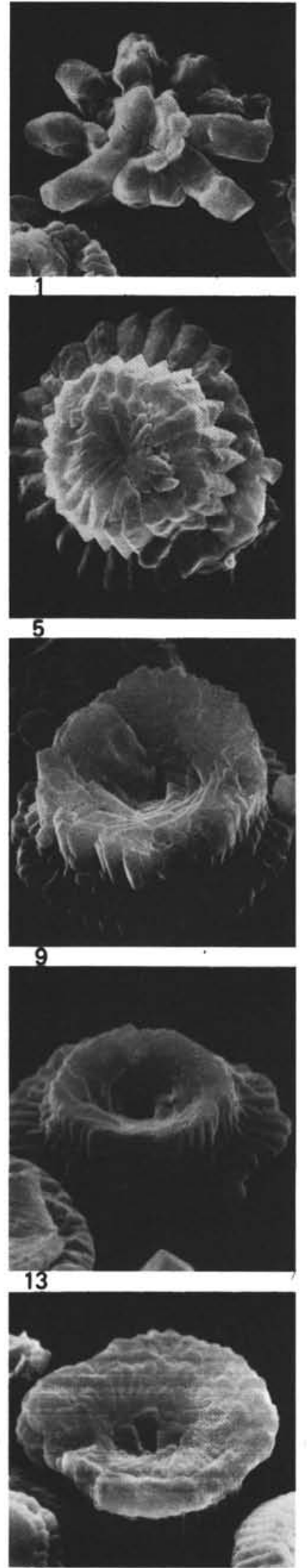

17
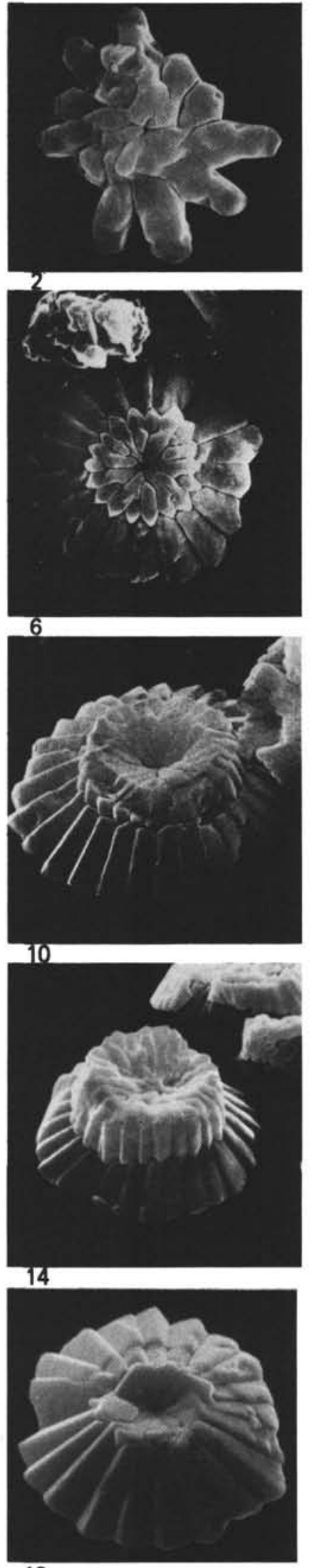

18
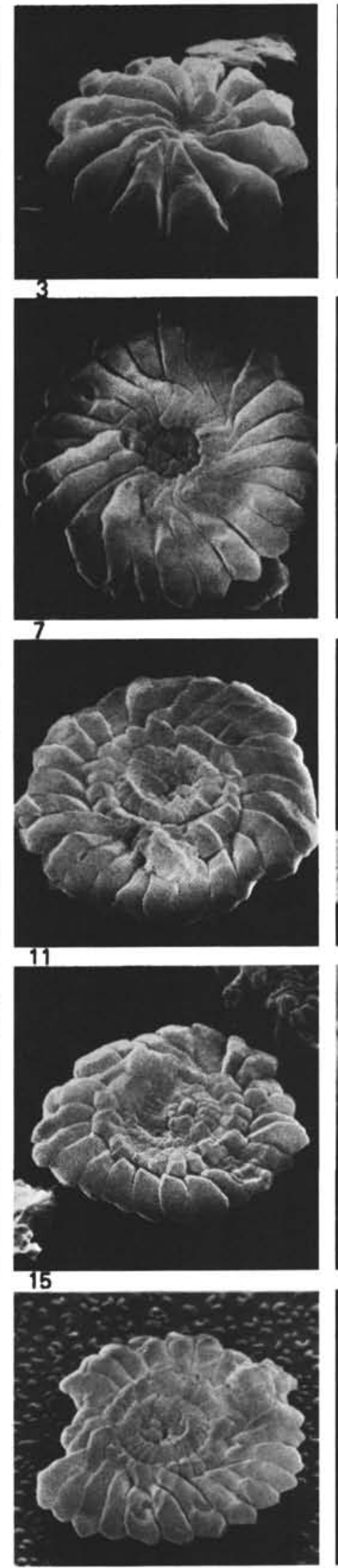

19
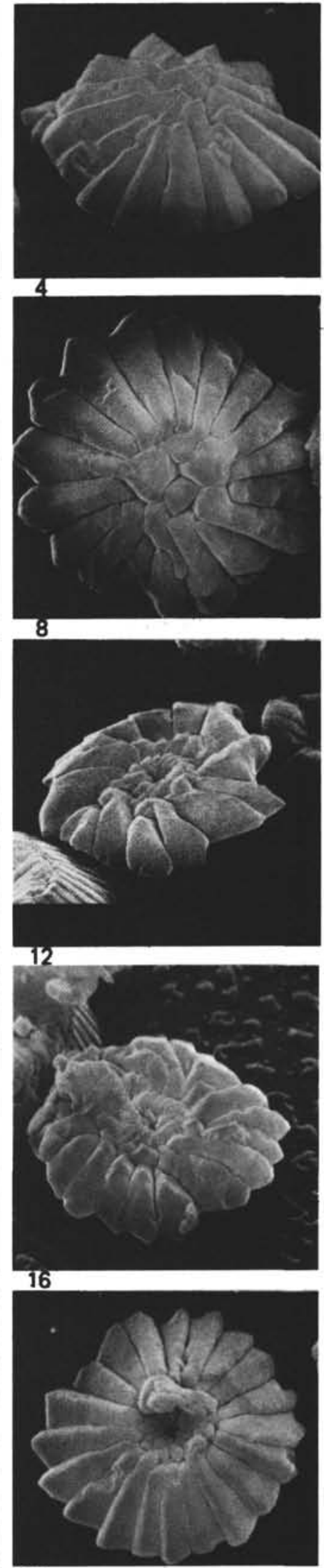

20 
PLATE 14
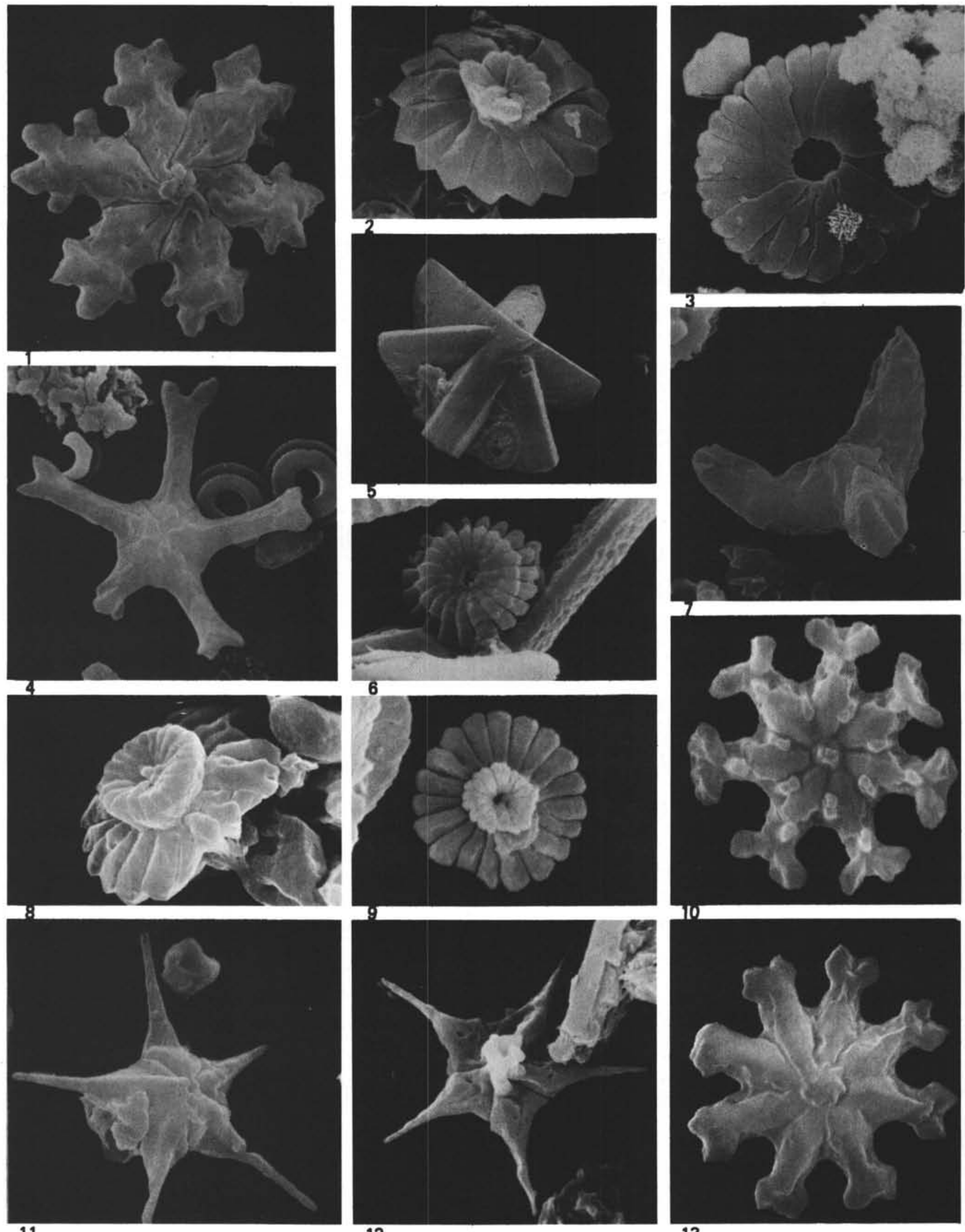
PLATE 15

Calcareous nannofossils from Samples 354-4-1, $120 \mathrm{~cm}$

(Figures 1, 7); 354-4-3, $20 \mathrm{~cm}$ (Figure 2); 356-2, CC,

(Figures 3, 4, 8); 354-4, CC, (Figures 5, 14); 354-4-5, $20 \mathrm{~cm}$ (Figures 6, 9, 13); 354-5-2, $69 \mathrm{~cm}$ (Figures 10, 11, 12);

354-5, CC (Figures 15, 17); 355-2, CC (Figure 16);

356-4-6, $70 \mathrm{~cm}$ (Figures 18, 19); 356-5-2, $77 \mathrm{~cm}$ (Figure 20).

Magnification $5000 \times$ (Figures 1, 11, 14, 20); 5500×

(Figure 2); 7000 $\times$ (Figures 3, 7, 12, 18); 10,000×

(Figures 4, 16); 4000× (Figure 6); 8000× (Figures 13, 17); $6000 \times$ (Figures 15, 19).

Figures 1,2, 5, Discoaster surculus Martini and Bramlette. 6,10

Figure 3 Discoaster asymmetricus Gartner.

Figure $4 \quad$ Discoaster tamalis Kamptner.

Figures 7,8 Discoaster pentaradiatus Tan Sin Hok.

Figure 9 Discoaster brouweri Tan Sin Hok.

Figures 11, 13 Discoaster challengeri Bramlette and Riedel.

Figures 12,15 Discoaster quinqueramus Gartner.

Figure 14 Discoaster variabilis Martini and Bramlette.

Figure 16 Hayaster perplexus (Bramlette and Riedel) Bukry.

Figure 17 Discoaster variabilis pansus Bukry and Percival.

Figures 18-20 Discoaster deflandrei Bramlette and Riedel; note small coccolith in process of being incorporated in an arm of the discoaster Figure 19. 
PLATE 15
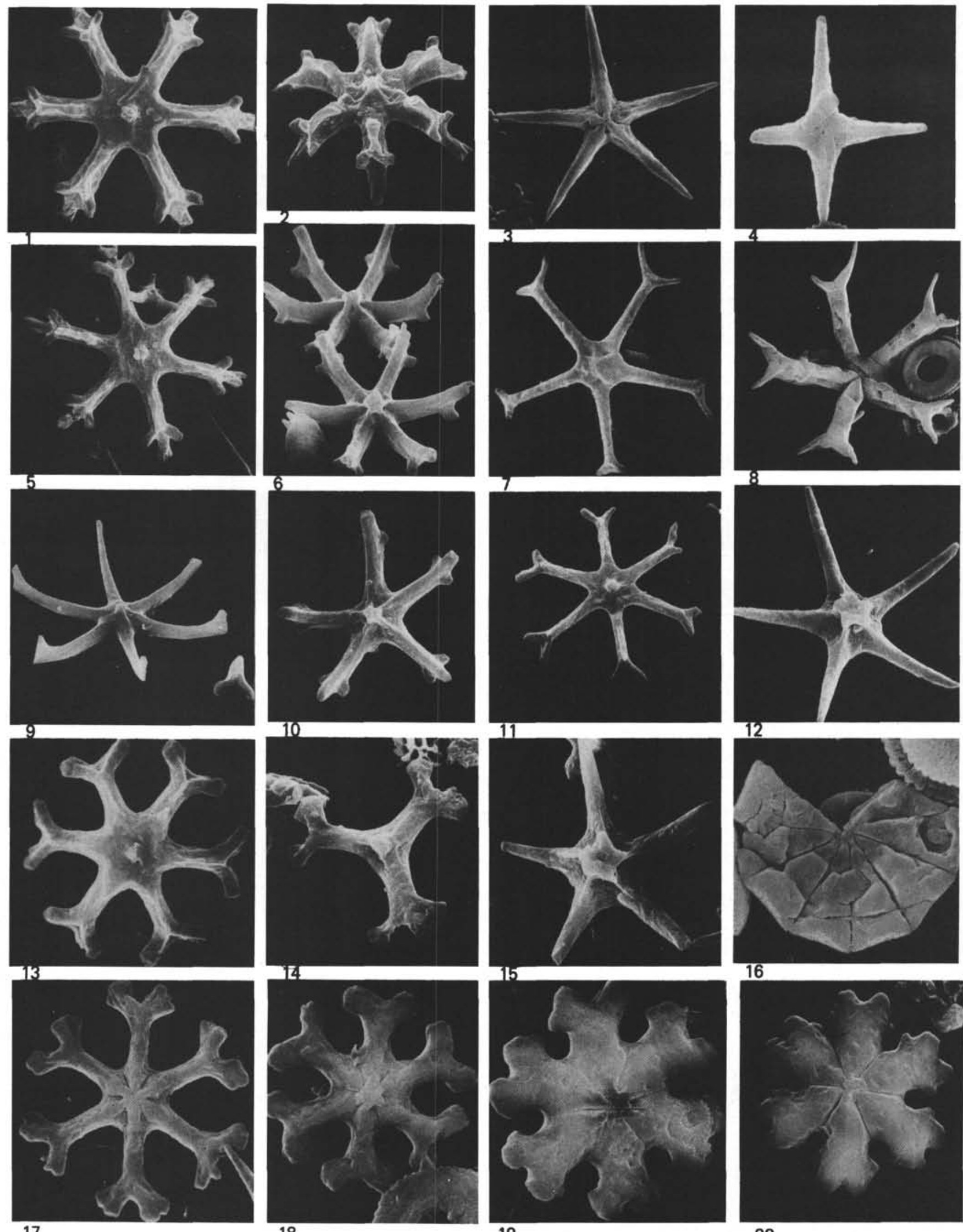


\section{PLATE 16}

Calcareous nannofossils from Samples $354-16-1,40 \mathrm{~cm}$

(Figures 1, 4-6); 354-16, CC (Figure 2); 358-13-1, $48 \mathrm{~cm}$ (Figure 3); 356-10-1, $110 \mathrm{~cm}$ (Figures 7-9); 356-28-3, $70 \mathrm{~cm}$ (Figure 10), 354-10, CC (Figure 11); 356-10-4, $70 \mathrm{~cm}$ (Figure 12).

Magnification 3900× (Figure 1); 6500× (Figures 2, 7, 11); $5800 \times$ (Figure 3); 4600 $\times$ (Figures 4, 5, 6, 9); $3600 \times$ (Figure 8); 5200 $\times$ (Figures 10, 12).

Figures 1, 4-6 Ericsonia cf. E. robusta (Bramlette and Sullivan) n. comb.

Figures 2,7 Ericsonia robusta (Bramlette and Sullivan) $\mathrm{n}$. comb. (Cyclolithus ? robustus Bramlette and Sullivan, 1961, p. 141, pl. 2, fig. 7).

Figures 3,11 Ericsonia subpertusa Hay and Mohler.

Figures 8,9 Ericsonia sp. 1; large form with a bridge visible on both sides and a relatively small proximal shield. NP15, middle Eocene.

Figure $10 \quad$ Ericsonia sp. 2; large form with narrow, elevated wall and large central opening. NP15, middle Eocene.

Figure $12 \quad$ Ericsonia sp. 3; small form with relatively small proximal shield. NP24, late Oligocene.

Figure 13 Ericsonia fenestrata (Deflandre and Fert) Stradner.

\section{PLATE 17}

Calcareous nannofossils from Samples $356-28-3,70 \mathrm{~cm}$

(Figures 1, 2, 3, 5, 7); 357-30-4, $120 \mathrm{~cm}$ (Figure 4);

$356-27-1,70 \mathrm{~cm}$ (Figure 6); 356-29-1, $96 \mathrm{~cm}$ (Figure 8).

Magnification $7600 \times$ (Figures 1, 2); 8500×

(Figure 3); 9500× (Figures 4-8).

Figures 1,2 Chiasmolithus danicus (Brotzen) Hay and Mohler.

Figures 3,5 Cruciplacolithus tenuis (Stradner) Hay and Mohler.

Figure $4 \quad$ Cruciplacolithus notus n. sp.; early form. Holotype.

Figure $6 \quad$ Cruciplacolithus sp. 1; wall extended flange-like on the distal side of the coccolith. NP3, early Paleocene.

Figures 7,8 Cruciplacolithus primus n. sp. Figure 8: Holotype. 


\section{PLATE 16}

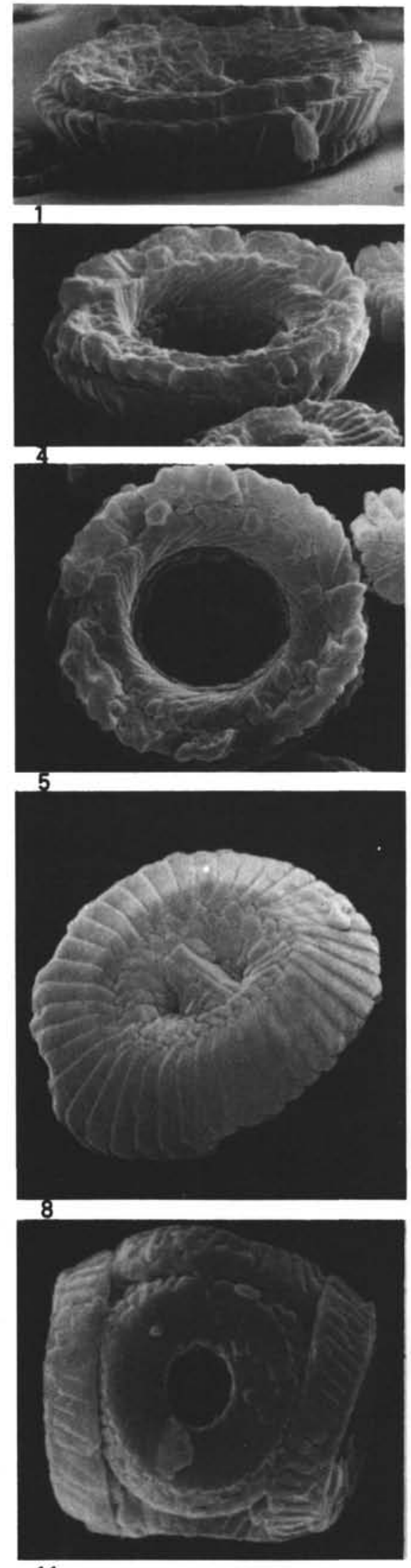

11
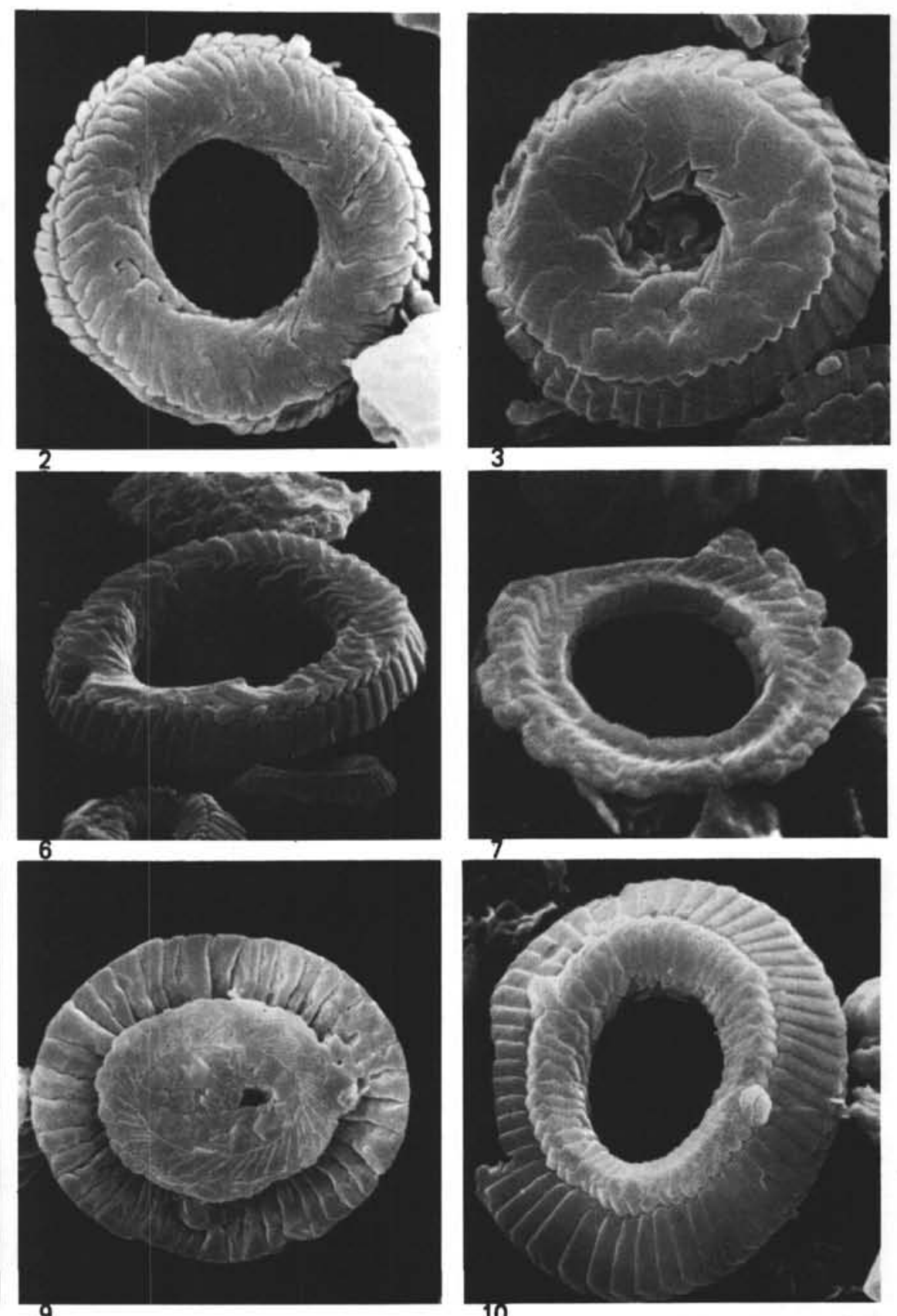

9
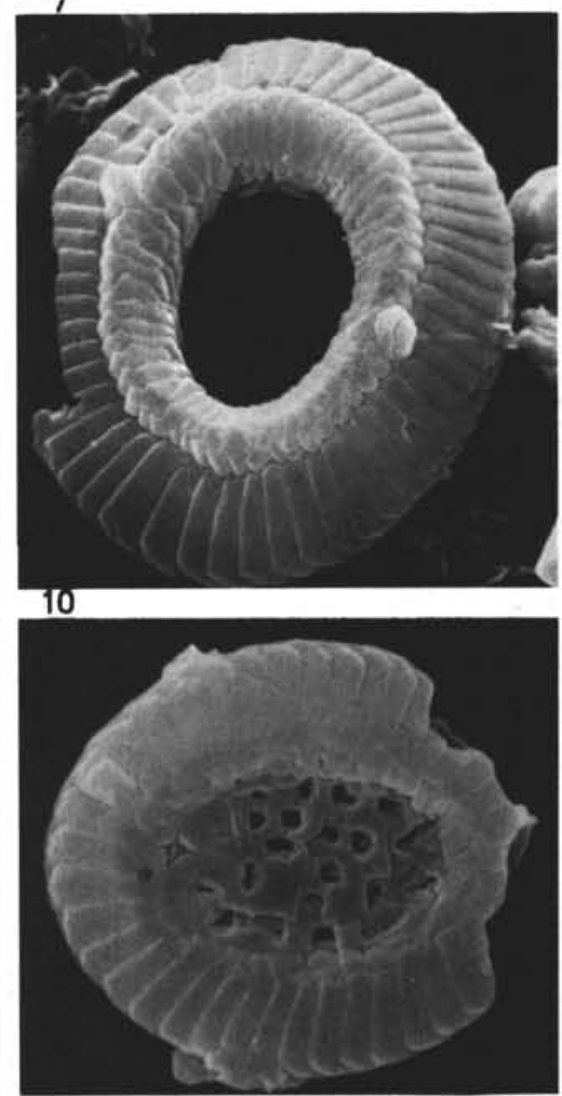

13 
PLATE 17
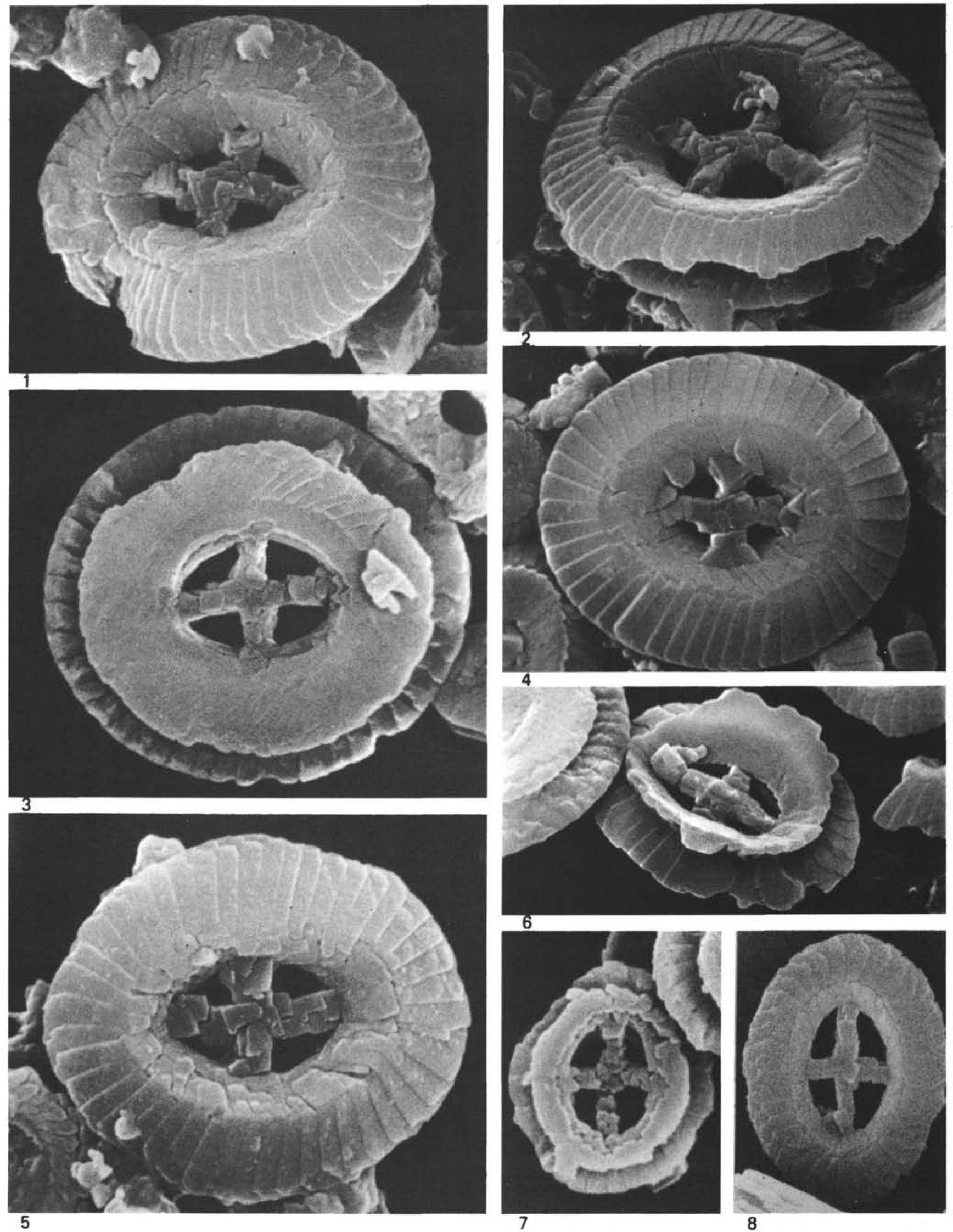
PLATE 18

Calcareous nannofossils from Samples 356-28-3, $70 \mathrm{~cm}$ (Figure 1); 356-23-2, $70 \mathrm{~cm}$ (Figures 2-5); 358-13-1, $45 \mathrm{~cm}$ (Figure 6).

Magnification $8000 \times$ (Figures 1, 5); 5200X

(Figure 2); 10,500× (Figure 3); 7000 $\times$ (Figure 4); $5000 \times$ (Figure 6).

Figure 1 Chiasmolithus danicus (Brotzen) Hay and Mohler.

Figures 2, 4 Chiasmolithus frequens. n. sp.

Figure 3 Chiasmolithus sp. 1; specimen with an unusual large central opening and flat shields. Solutionrest? NP5, late Paleocene.

Figures 5,6 Chiasmolithus bidens (Bramlette and Sullivan) Hay and Mohler.

(see page 778)

PLATE 19

Calcareous nannofossils from Samples 354-16-6, $40 \mathrm{~cm}$

(Figure 1); 354-16-6, $90 \mathrm{~cm}$ (Figures 2, 3)

356-16-6, $120 \mathrm{~cm}$ (Figures 4, 5); 356-17, CC (Figure 6).

Magnification $6000 \times$ (Figures 1, 3, 5); 10,000×

(Figure 2); $9000 \times$ (Figure 4); $8000 \times$ (Figure 6).

Figures 1, 3, 5 Chiasmolithus frequens $\mathrm{n}$. sp. Holotype: Figure 3.

Figures 2, 4,6 Chiasmolithus consuetus (Bramlette and Sullivan) Hay and Mohler.

(see page 779)

PLATE 20

Calcareous nannofossils from Samples 357-17-1, $92 \mathrm{~cm}$ (Figures 1, 2); 357-20-1, $121 \mathrm{~cm}$ (Figure 3); 356-9-2, $70 \mathrm{~cm}$

(Figures 4, 5-7); 357-26-4, $48 \mathrm{~cm}$ (Figure 8); 356-10, CC (Figure 9).

Magnification 5600 $\times$ (Figures 1, 8); 6400×

(Figures 2, 7); 4000 $\times$ (Figures 3, 4, 9); $3200 \times$ (Figures 5, 6).

Figures 1,2 Chiasmolithus altus Bukry and Percival.

Figure 3 Chiasmolithus oamaruensis (Deflandre) Hay, Mohler, and Wade.

Figures 4, 7 Chiasmolithus nitidus Perch-Nielsen.

Figure 5 Chiasmolithus gigas (Bramlette and Sullivan) Radomski.

Figure 6 Chiasmolithus grandis (Bramlette and Riedel) Radomski.

Figures 8,9 Chiasmolithus solitus (Bramlette and Sullivan) Locker. 
PLATE 18
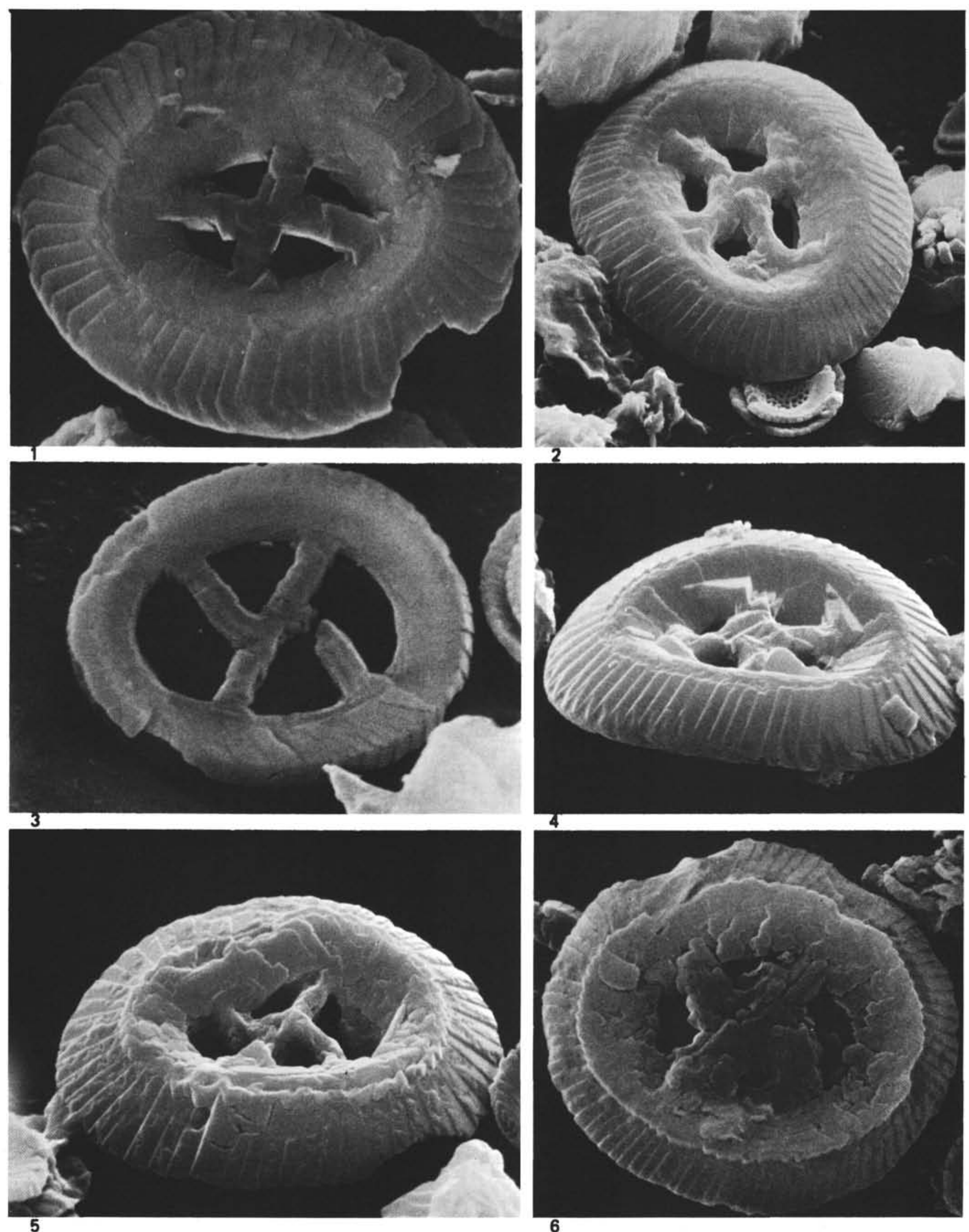
PLATE 19
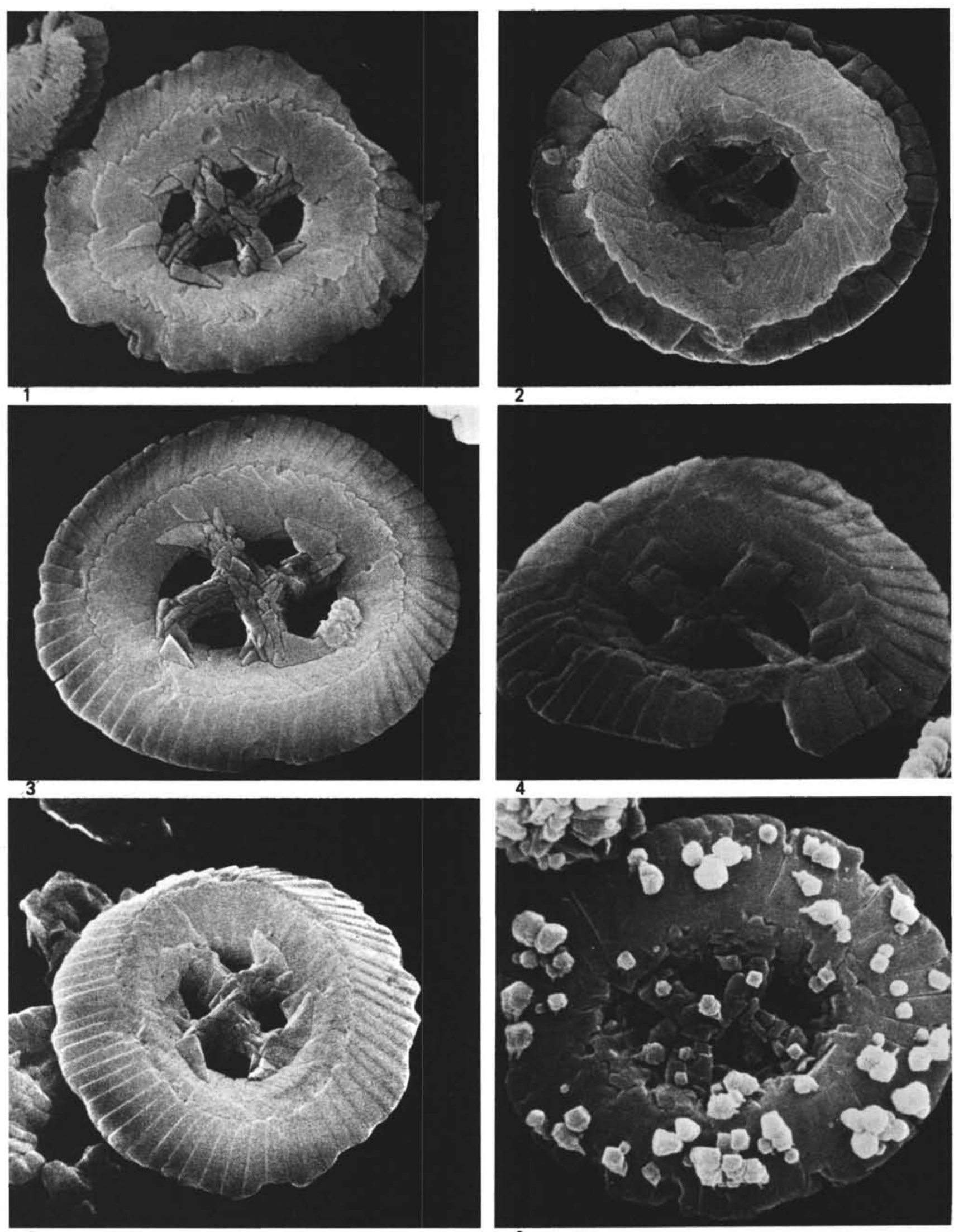


\section{PLATE 20}
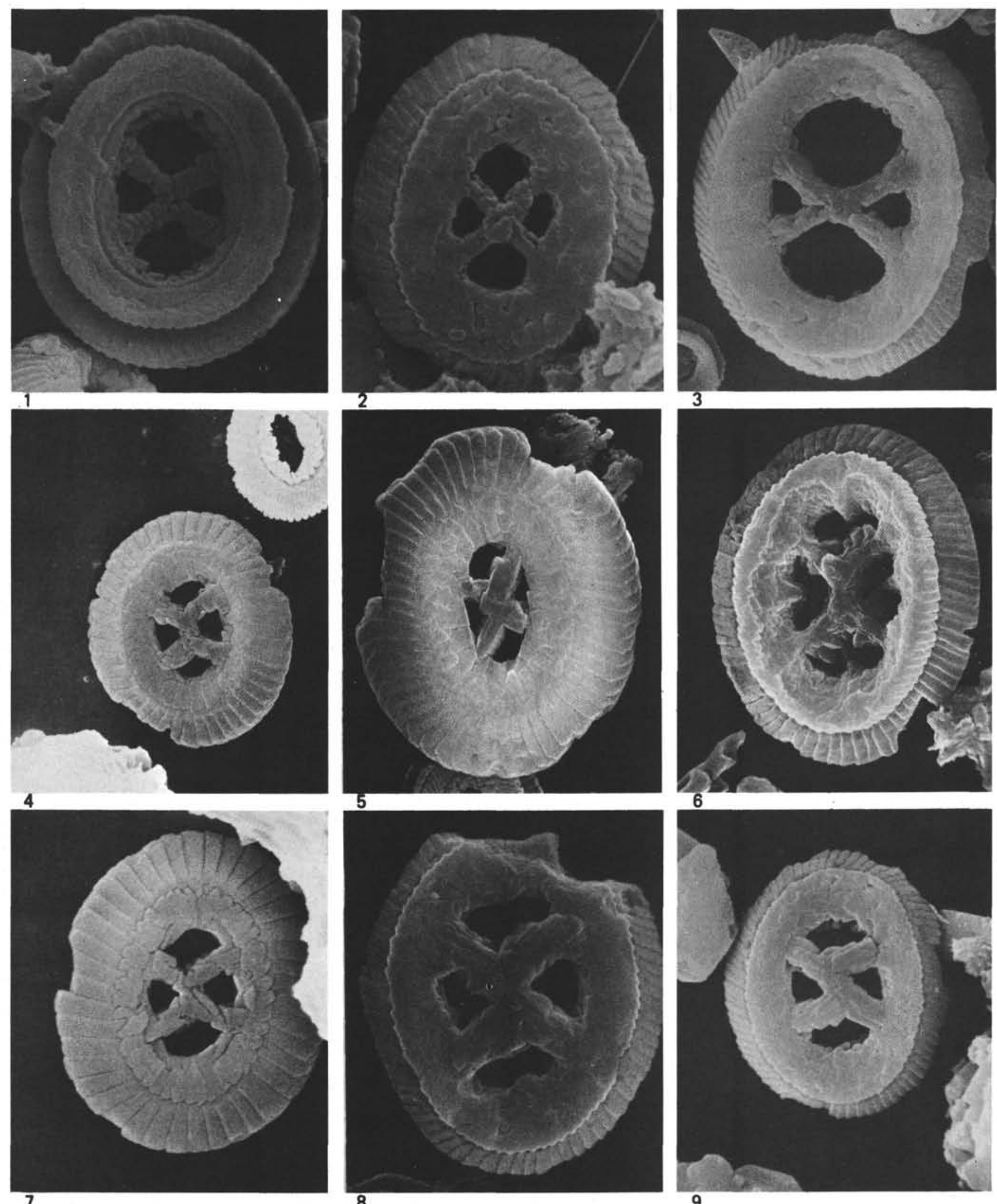


\section{PLATE 21}

Calcareous nannofossils from Samples 356-7-3, $70 \mathrm{~cm}$

(Figures 1-4) and 356-10-1, $110 \mathrm{~cm}$ (Figures 5, 6).

Magnification $6000 \times$ (Figures 1, 3, 5); 5500×

(Figure 2); 9000× (Figure 6).

Figures 1-3 Helicopontosphaera papillata Bukry and Bramlette.

Figure 4 Helicopontosphaera seminulum (Bramlette and Sullivan) Bukry.

Figure 5 Helicopontosphaera lophota (Bramlette and Sullivan) Bukry et al.

Figures $6 \quad$ Helicopontosphaera sp. 1.

(see page 782)

\section{PLATE 22}

Calcareous nannofossils from Samples 354-10, CC (Figures 1, 5); 354-1, CC (Figure 2); 354-13, CC (Figure 4); 355-2, CC (Figure 3); $357-26-4,48 \mathrm{~cm}$ (Figures 6, 7).

Magnification $8500 \times$ (Figures 1, 7); 7600 $\times$ (Figure 2); $6000 \times$ (Figures 3-5); 5500 $\times$ (Figure 5).

Figure $1 \quad$ Helicopontosphaera recta (Haq) Martini.

Figure 2 Helicopontosphaera hyalina (Gaarder) Haq.

Figure 3 Helicopontosphaera wallichi (Lohmann) Boudreaux and Hay.

Figure 4 Helicopontosphaera reticulata (Bramlette and Wilcoxon) Bukry et al.

Figure 5 Helicopontosphaera euphratis (Haq) Martini.

Figure 6 Helicopontosphaera heezenii Bukry.

Figure 7 Helicopontosphaera seminulum (Bramlette and Sullivan) Bukry.

(see page 783)

\section{PLATE 23}

Calcareous nannofossils from Samples 357-17-1, $92 \mathrm{~cm}$

(Figures 1-8) and 357-19, CC (Figures 9, 10).

Magnification $6000 \times$.

Figures 1-3 Helicopontosphaera recta (Haq) Martini.

Figures 4-8, 10 Helicopontosphaera obliqua (Bramlette and Wilcoxon) Haq.

Figure 9 Helicopontosphaera perch-nielsenae Haq. 
PLATE 21
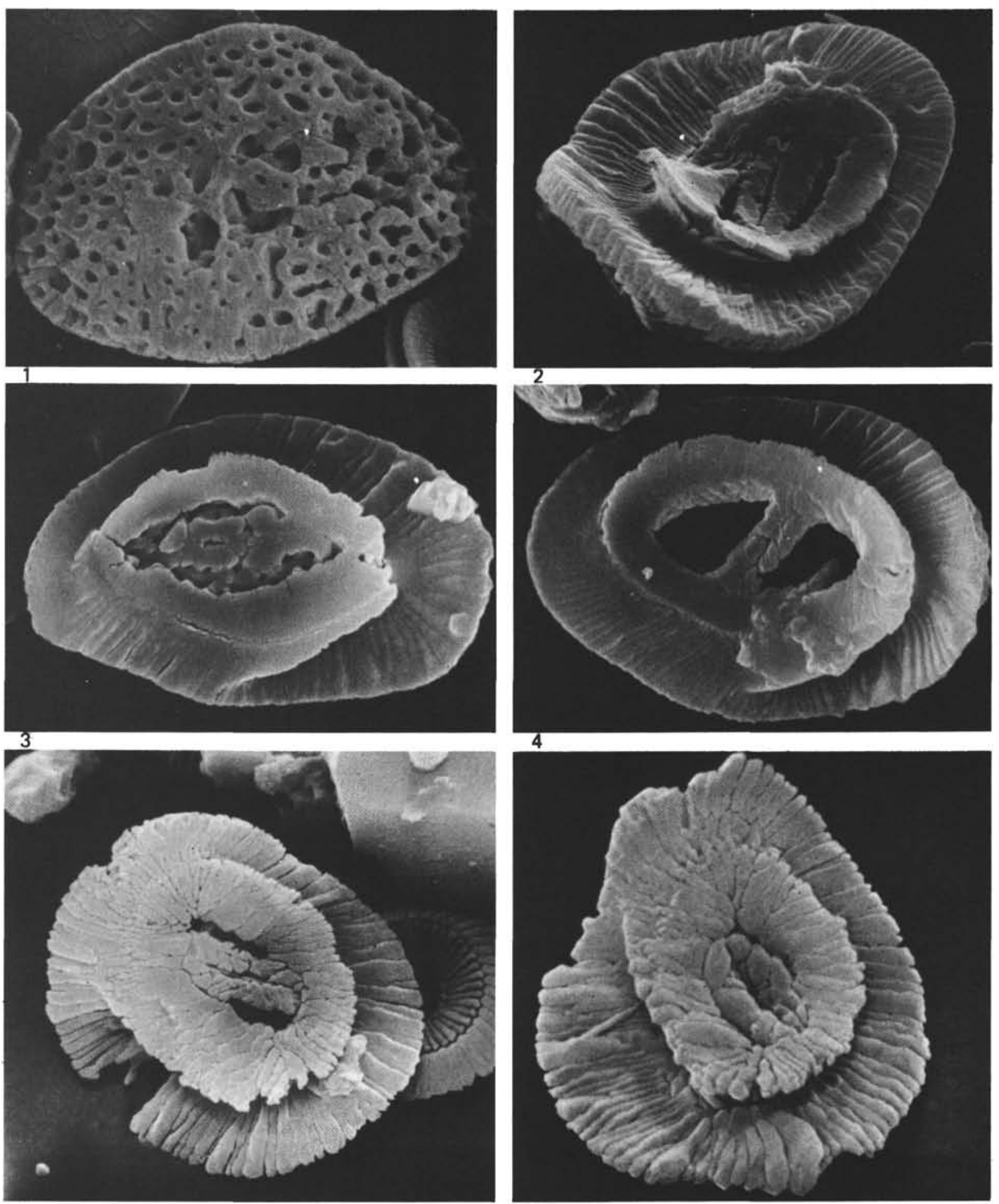

5

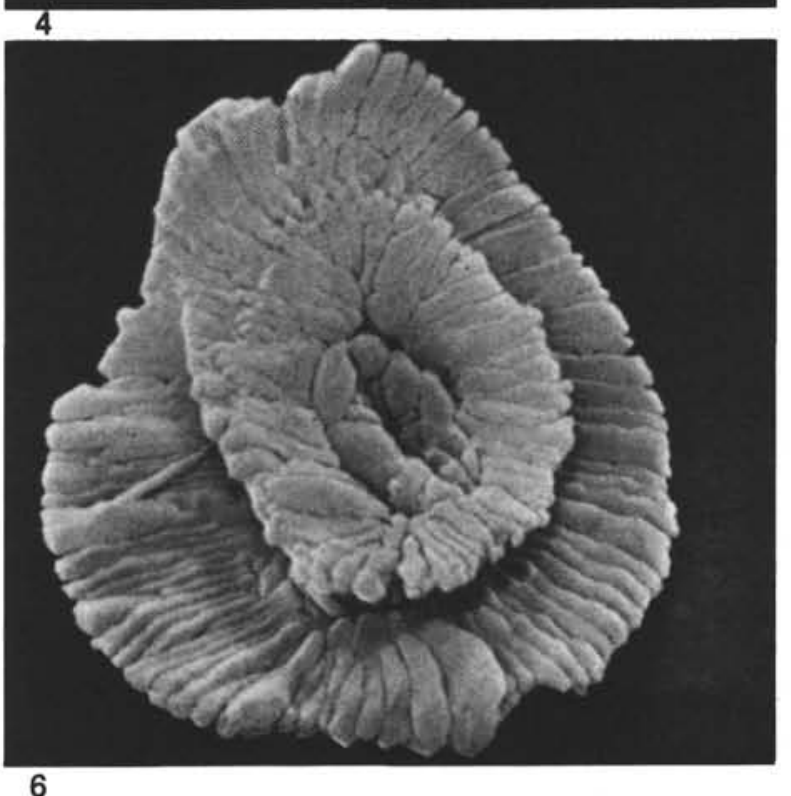




\section{PLATE 22}
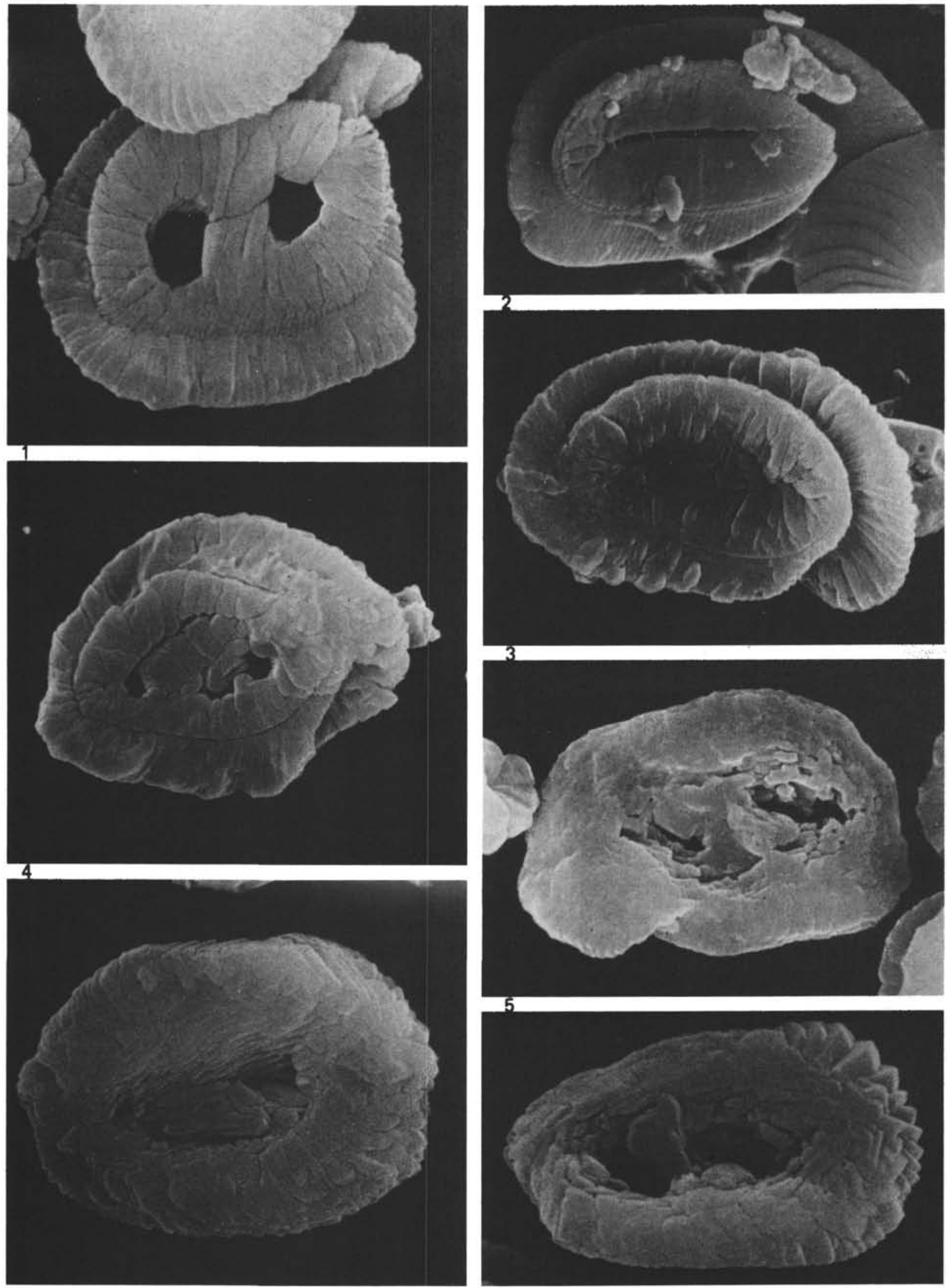


\section{PLATE 23}

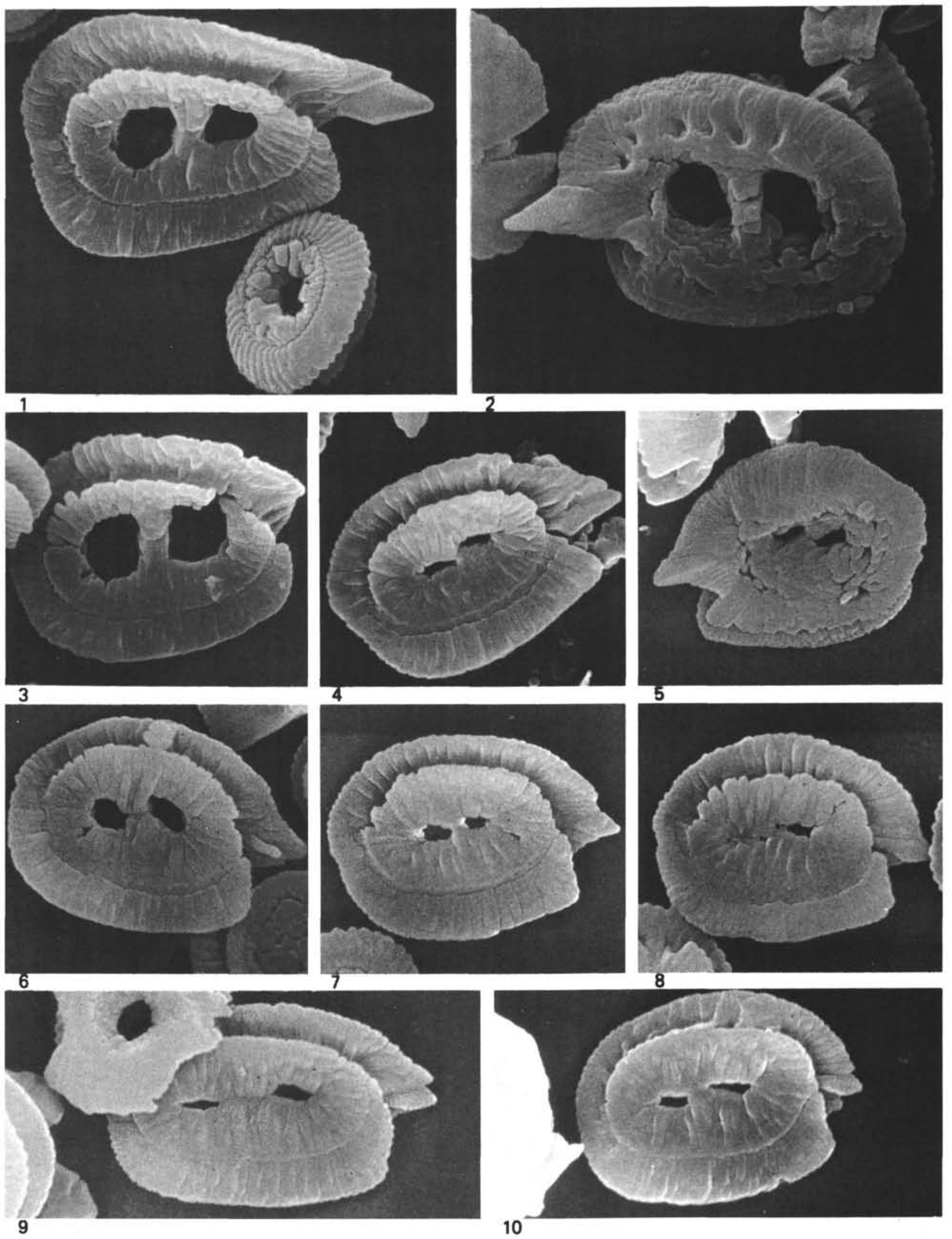




\section{PLATE 24}

Calcareous nannofossils from Samples 356-2, CC (Figure 1); 356-10, CC (Figures 2, 4); 357-14, CC (Figures 3, 5); $357-17-1,92 \mathrm{~cm}$ (Figure 6).

Magnification $7700 \times$.

Figure 1 Helicopontosphaera wallichi (Lohmann) Boudreaux and Hay.

Figure 2 Helicopontosphaera obliqua (Bramlette and Wilcoxon) Haq.

Figures 3, 5, 6 Helicopontosphaera rhomba Bukry.

Figure $4 \quad$ Helicopontosphaera sp. 2.

PLATE 25

Calcareous nannofossils from Sample 357-10, CC.

Magnification $7700 \times$.

Figures 1-6 Helicopontosphaera granulata Bukry and Percival.

(see page 787)

\section{PLATE 26}

Calcareous nannofossils from Sample 356-4-6, $70 \mathrm{~cm}$.

Magnification $8700 \times$ (Figure 1); $6800 \times$ (Figure 2);

$7800 \times$ (Figures 3, 6); 6300 $\times$ (Figure 4); 10,700 $\times$ (Figure 5).

Figures 1, 3,5 Helicopontosphaera recta (Haq) Martini.

Figures 2, 4, 6 Helicopontosphaera granulata Bukry and Percival. Specimens with a nearly rectangular, large flange.

(see page 788) 
PLATE 24
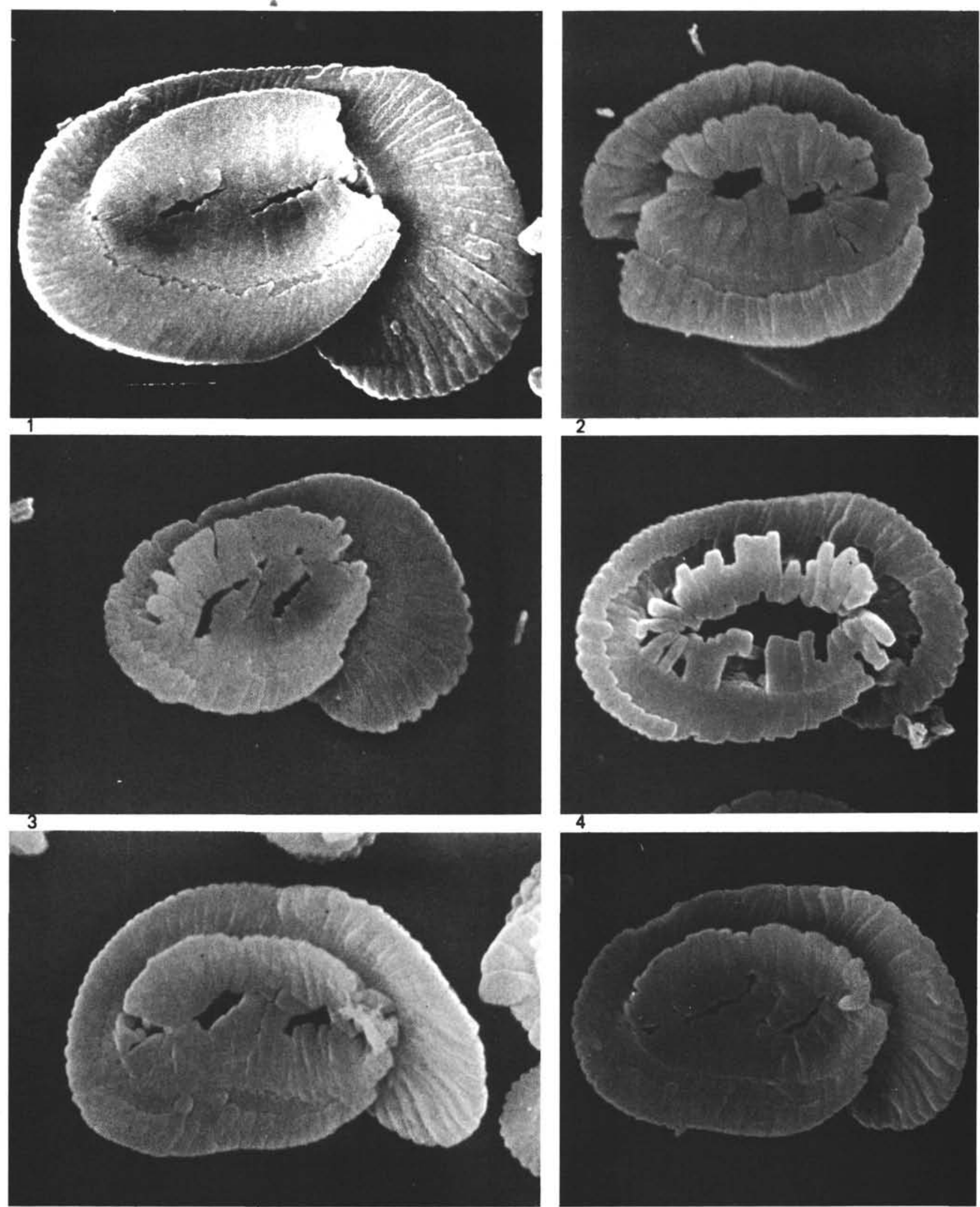
PLATE 25
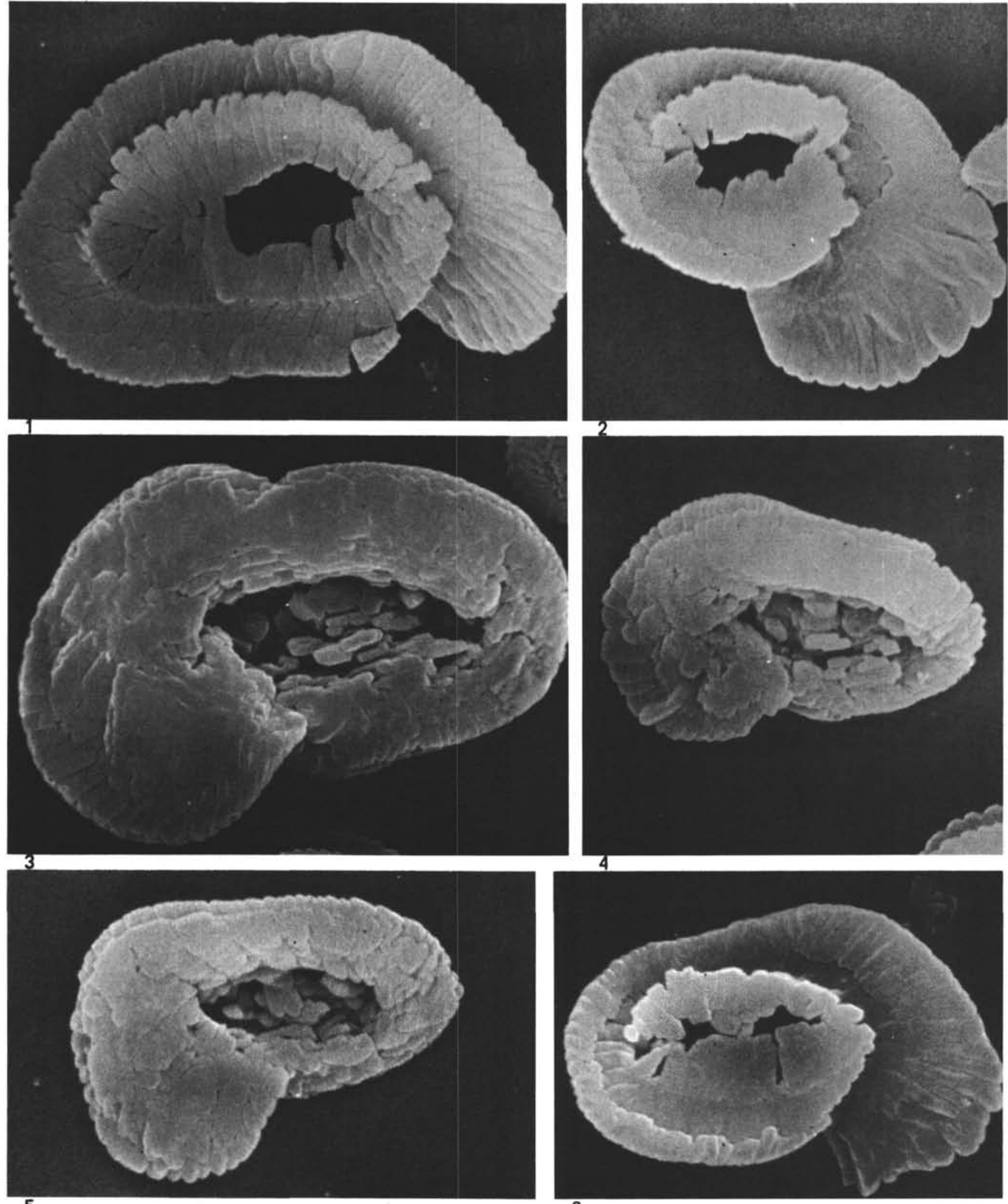

6 
PLATE 26
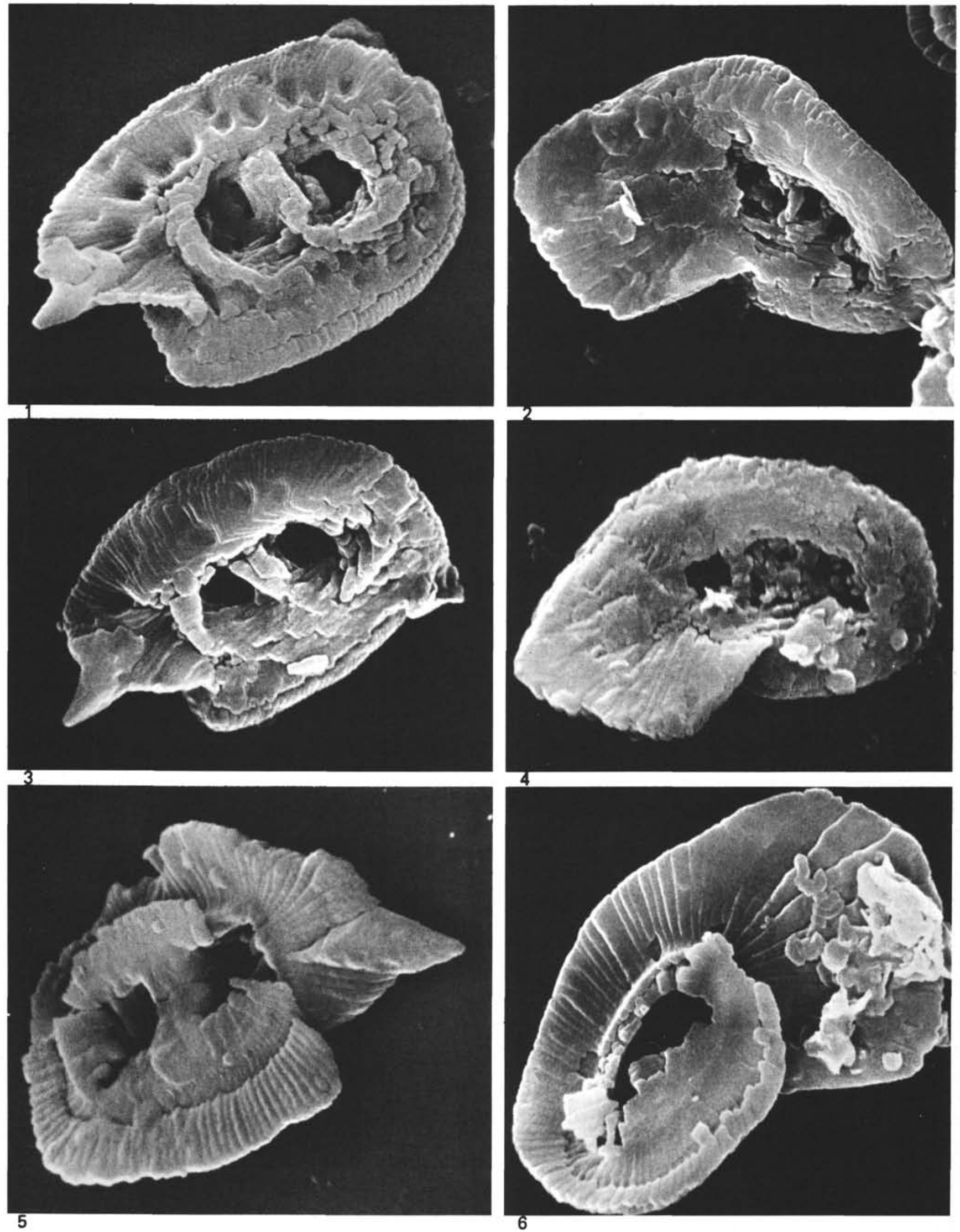


\section{PLATE 27}

Calcareous nannofossils from Samples 356-1, CC (Figures 1, 4); 356-7-3, $70 \mathrm{~cm}$ (Figures 2, 3, 6, 9, 12); 356-10, CC (Figure 5); $356-10-1,110 \mathrm{~cm}$ (Figures 7, 10); 354-4-3, $20 \mathrm{~cm}$ (Figure 8); $357-26-4,48 \mathrm{~cm}$ (Figure 11).

Magnification 12,000× (Figures 1, 4); 6000× (Figure 2); $3750 \times$ (Figures 3, 5, 8-10); 7500 $\times$ (Figure 6); 5250×

(Figures 7, 11, 12).

Figures 1,4 Syracosphaera pulchra Lohmann.

Figures 2, 3 Pontosphaera excelsa (Perch-Nielsen) n. comb. (Koczyia excelsa Perch-Nielsen, 1971, p. 37, pl. 28 , fig. 1-5, pl. 60, fig. 16).

Figure $5 \quad$ Pontosphaera labrosa (Bukry and Bramlette) $n$. comb. (Syracosphaera labiosa Bukry and Bramlette, 1969, p. 141, pl. 3, fig. 15-17).

Figure $6 \quad$ Neococcolithes dubius (Deflandre) Black.

Figure $7 \quad$ Lophodolithus cf. L. nascens Bramlette and Sullivan.

Figures 10,11 Lophodolithus acutus Bukry and Percival.

Figure $8 \quad$ Pontosphaera discopora Schiller.

Figure 9 Pontosphaera multipora (Kamptner) Roth.

Figure 12 Transversopontis sp.

(see page 790)

\section{PLATE 28}

Calcareous nannofossils from Samples 356-9-2, $70 \mathrm{~cm}$

(Figures 1-4); 356-10, CC (Figure 5); 356-10-1, $110 \mathrm{~cm}$ (Figure 6).

Magnification 4350× (Figures 1, 3-6); 8500× (Figure 2).

Figures 1-4 Lophodolithus rotundus Bukry and Percival.

Figure $5 \quad$ Lophodolithus cf. L. nascens Bramlette and Sullivan.

Figure 6 Pontosphaera labrosa (Bukry and Bramlette) $\mathrm{n}$. comb. 
PLATE 27
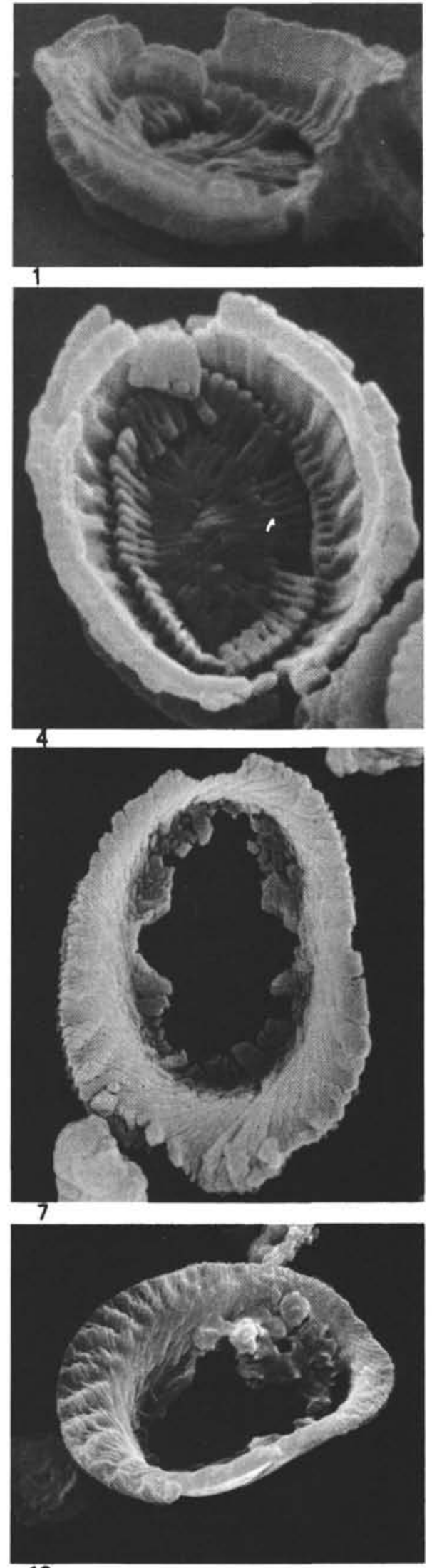
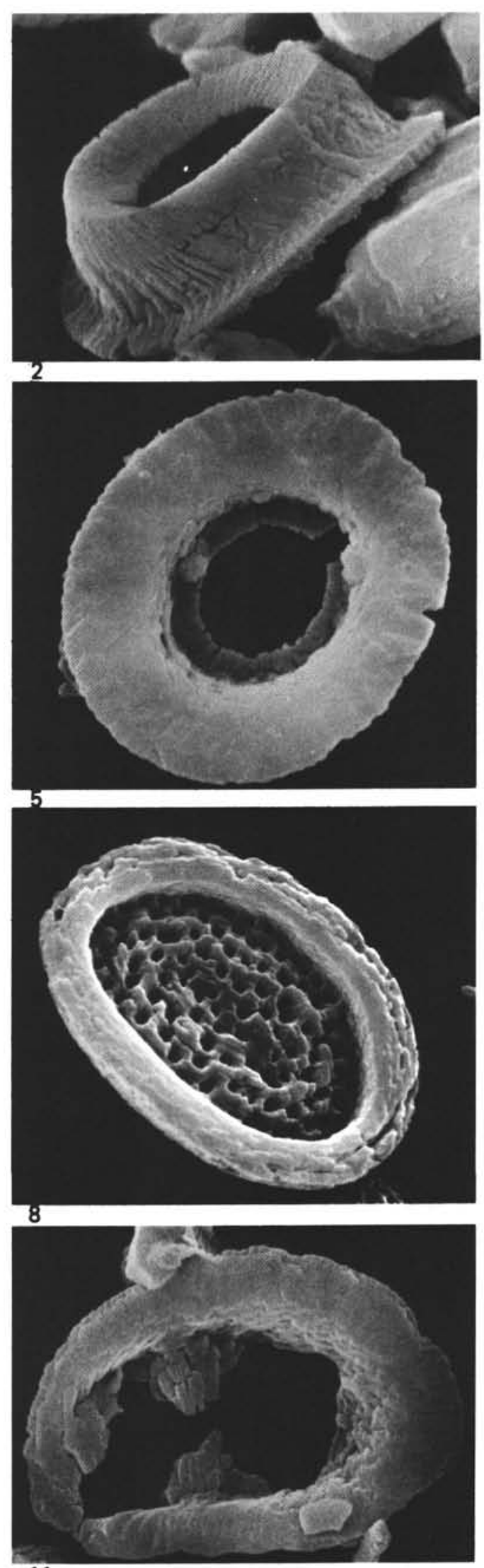
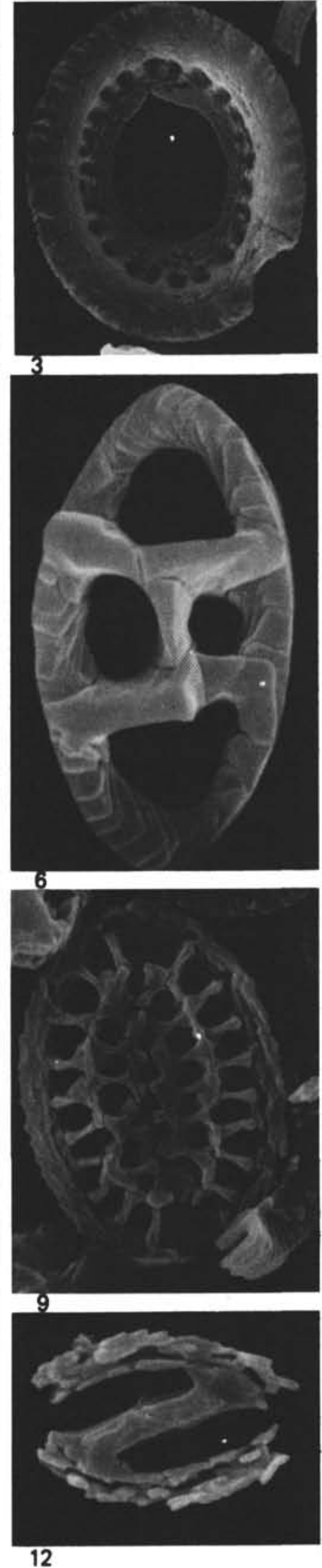


\section{PLATE 28}
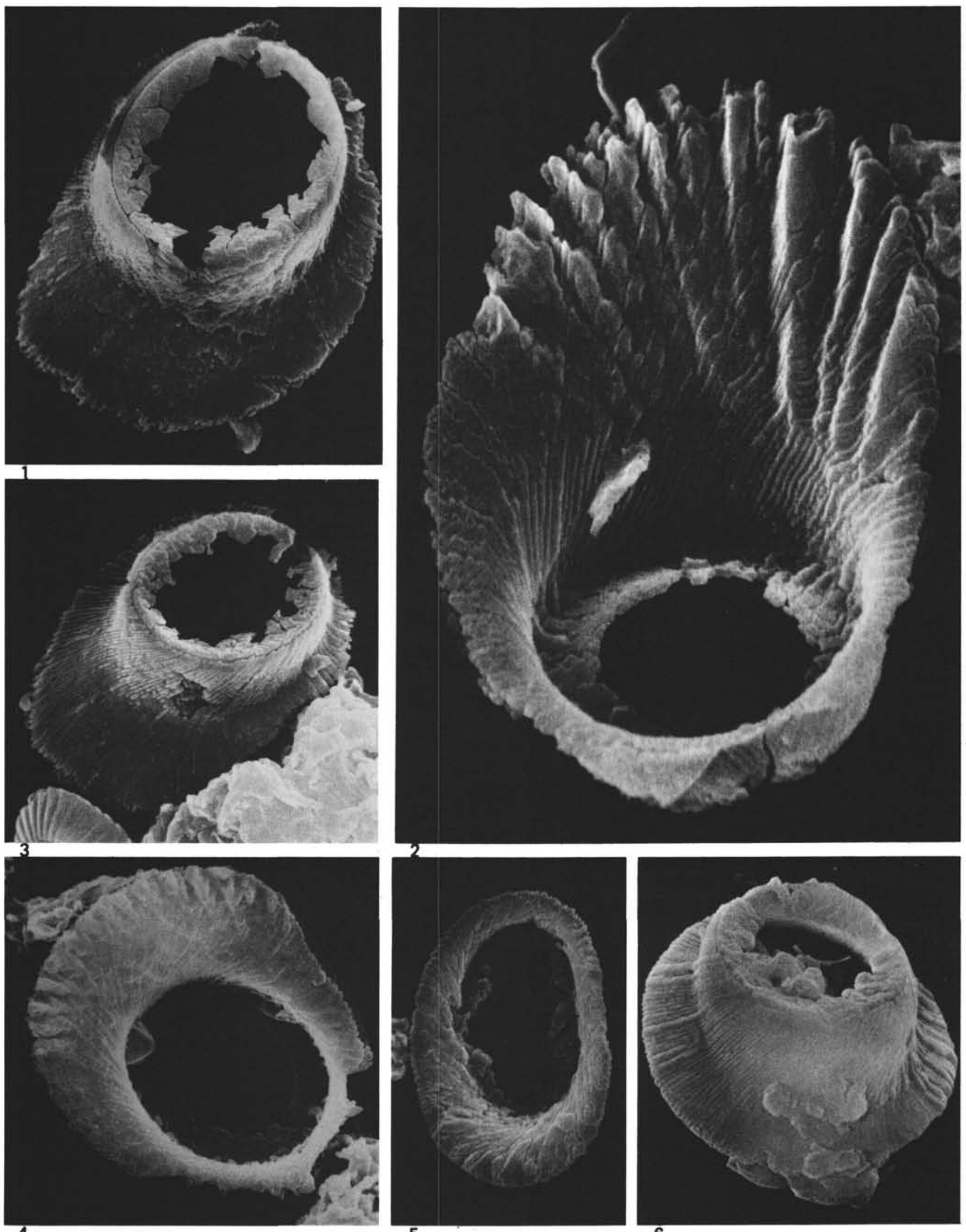

5

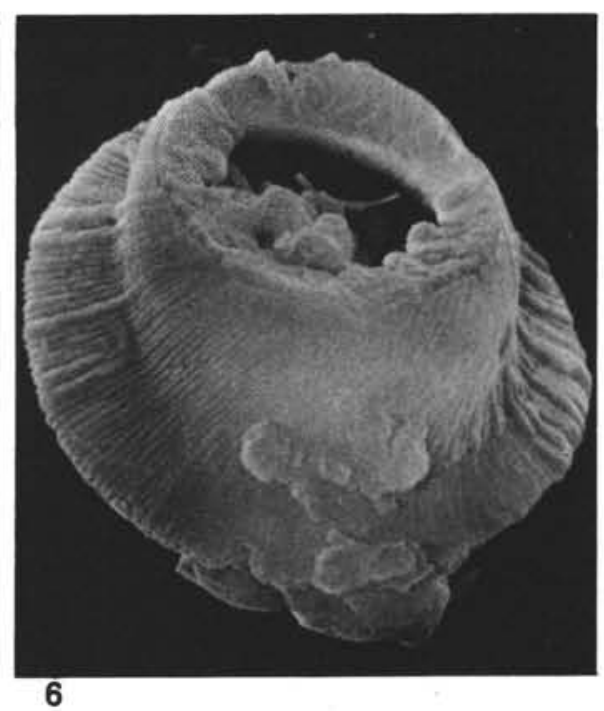




\section{PLATE 29}

Calcareous nannofossils from Samples 354-4, CC

(Figures 1, 4, 5, 7, 8); 354-4-3, $20 \mathrm{~cm}$ (Figure 2); 354-6-2, $25 \mathrm{~cm}$ (Figure 6); 354-4-1, $120 \mathrm{~cm}$ (Figures 9, 11); $354-4-6,120 \mathrm{~cm}$ (Figure 10); 354-5-2, $69 \mathrm{~cm}$ (Figure 12); 356-2, CC (Figures 13, 14); 354-5, CC (Figures 15, 16).

Magnification 3100 $\times$ (Figures 1-7, 9, 11-16); $6200 \times$ (Figure 8); 2500× (Figure 10).

Figures 1,2 Scyphosphaera globulata Bukry and Percival.

Figures 3, 4,6 Scyphosphaera pulcherrima Deflandre.

Figures 5, 14, 15 Scyphosphaera recurvata Deflandre.

Figures 7,9 Scyphosphaera amphora Deflandre.

Figure $8 \quad$ Scyphosphaera sp. 1.

Figures 10,11 Scyphosphaera intermedia Deflandre.

Figures 12 Scyphosphaera cohenii Boudreaux and Hay.

Figure 13 Scyphosphaera recta (Deflandre) Kamptner.

Figure 16 Scyphosphaera apsteinii Lohmann. 


\section{PLATE 29}
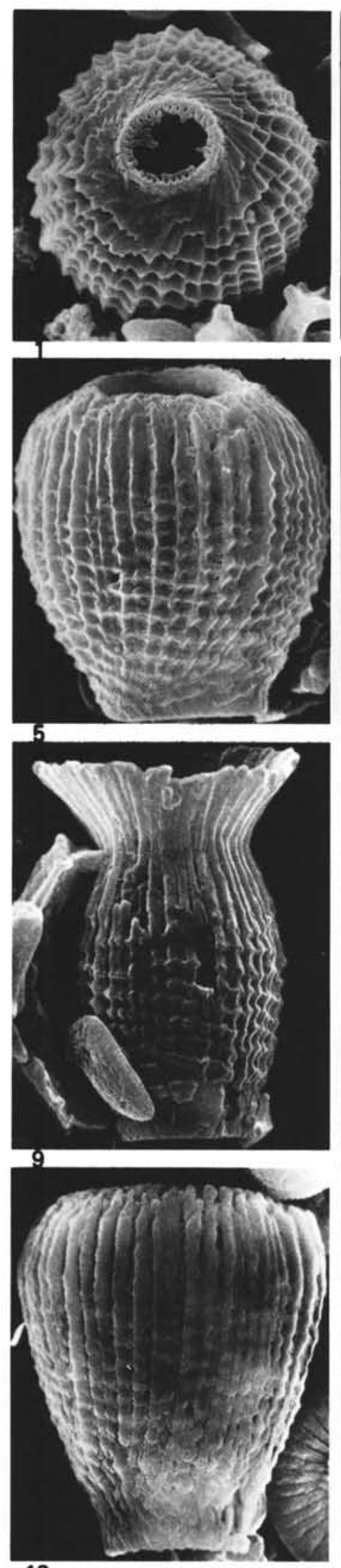

13
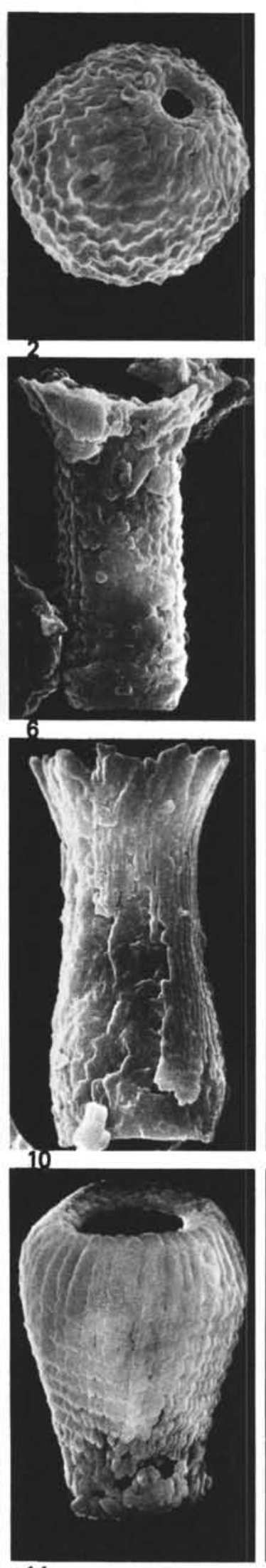

14
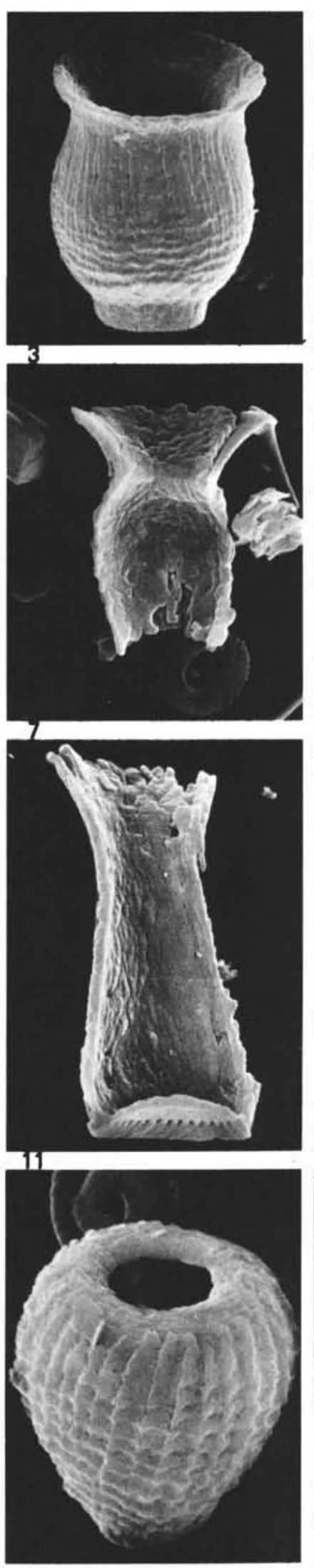

15
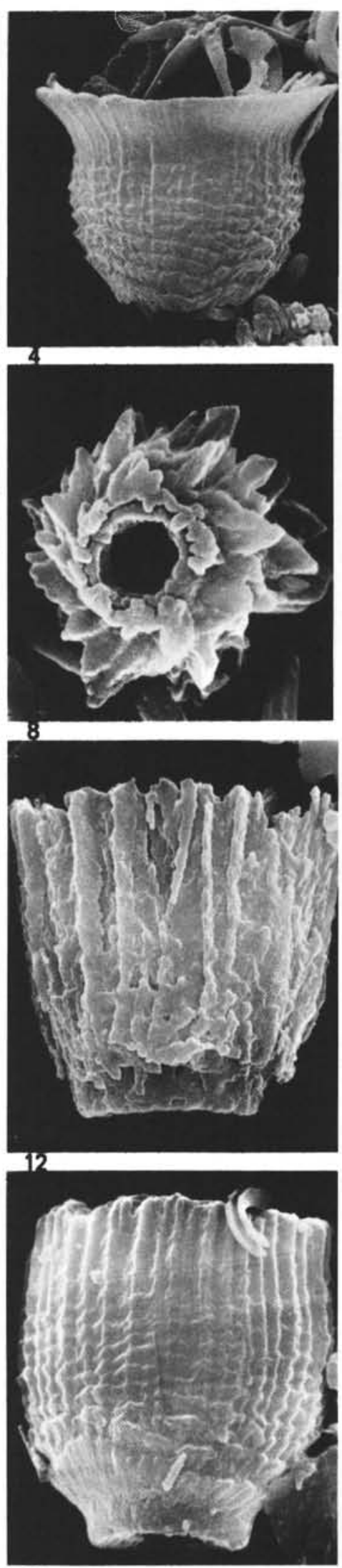

16 


\section{PLATE 30}

Calcareous nannofossils from Samples 357-20-1, 121 (Figure 1); 354-13, CC (Figure 2); 358-13-1, $45 \mathrm{~cm}$ (Figures 3, 6); 356-23-2, $70 \mathrm{~cm}$ (Figures 4, 5, 7); 356-25-5, $30 \mathrm{~cm}$ (Figures 8, 9); 356-28-3, $70 \mathrm{~cm}$ (Figures 10-13).

Magnification $7500 \times$ (Figures 1, 3, 4, 6-9, 12, 13); $4500 \times$ (Figure 2); $8000 \times$ (Figure 5); 15,000 $\times$ (Figure 10); 6800× (Figure 11).

Figure 1 Reticulofenestra umbilica (?) (Levin) Martini and Ritzkowski; specimen, where the shields have been eroded and only the wall and connecting parts of the shields are left?

Figure 2 Reticulofenestra dictyoda (Deflandre) Stradner; note the circular hole probably due to fungi (?).

Figure 3 Prinsius martinii (Perch-Nielsen) Haq.

Figure 4 Toweius craticulus Hay and Mohler.

Figures 5, 8, 9 Toweius sp. 1; small form with relatively wide distal shield, narrow walls and large distal and small proximal performations.

Figure $6 \quad$ Toweius eminens (?) (Bramlette and Sullivan) Perch-Nielsen; partly overgrown specimen.

Figure $7 \quad$ Toweius sp. 2; very small form with small perforations distally.

Figures 10-13 Prinsius dimorphosus (Perch-Nielsen); n. comb. (Biscutum ? dimorphosum Perch-Nielsen, 1969, p. 57, pl. 4, fig. 6-12); coccosphere and pieces of coccospheres.

\section{PLATE 31}

Calcareous nannofossils from Samples 354-14-1, $35 \mathrm{~cm}$

(Figures 1-3, 7) and 357-26-4, $48 \mathrm{~cm}$ (Figures 4-6, 8).

$$
\text { Magnification } 11,000 \times \text {. }
$$

Figure $1 \quad$ Sphenolithus obtusus Bukry.

Figures 2-5 Sphenolithus furcatolithoides Locker.

Figures 6,7 Sphenolithus spiniger Bukry.

Figure 8 Sphenolithus radians Deflandre. 
PLATE 30
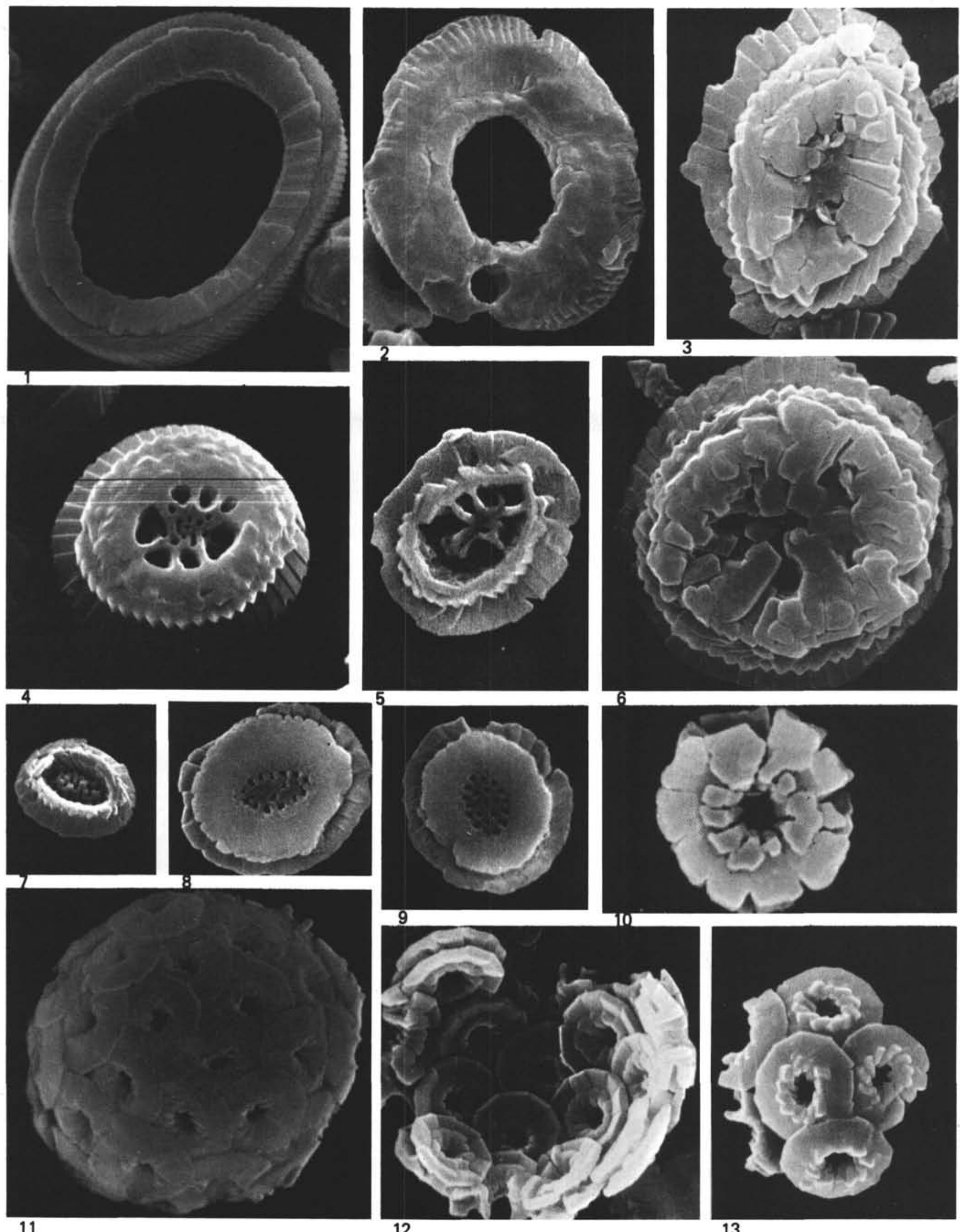

13 
PLATE 31
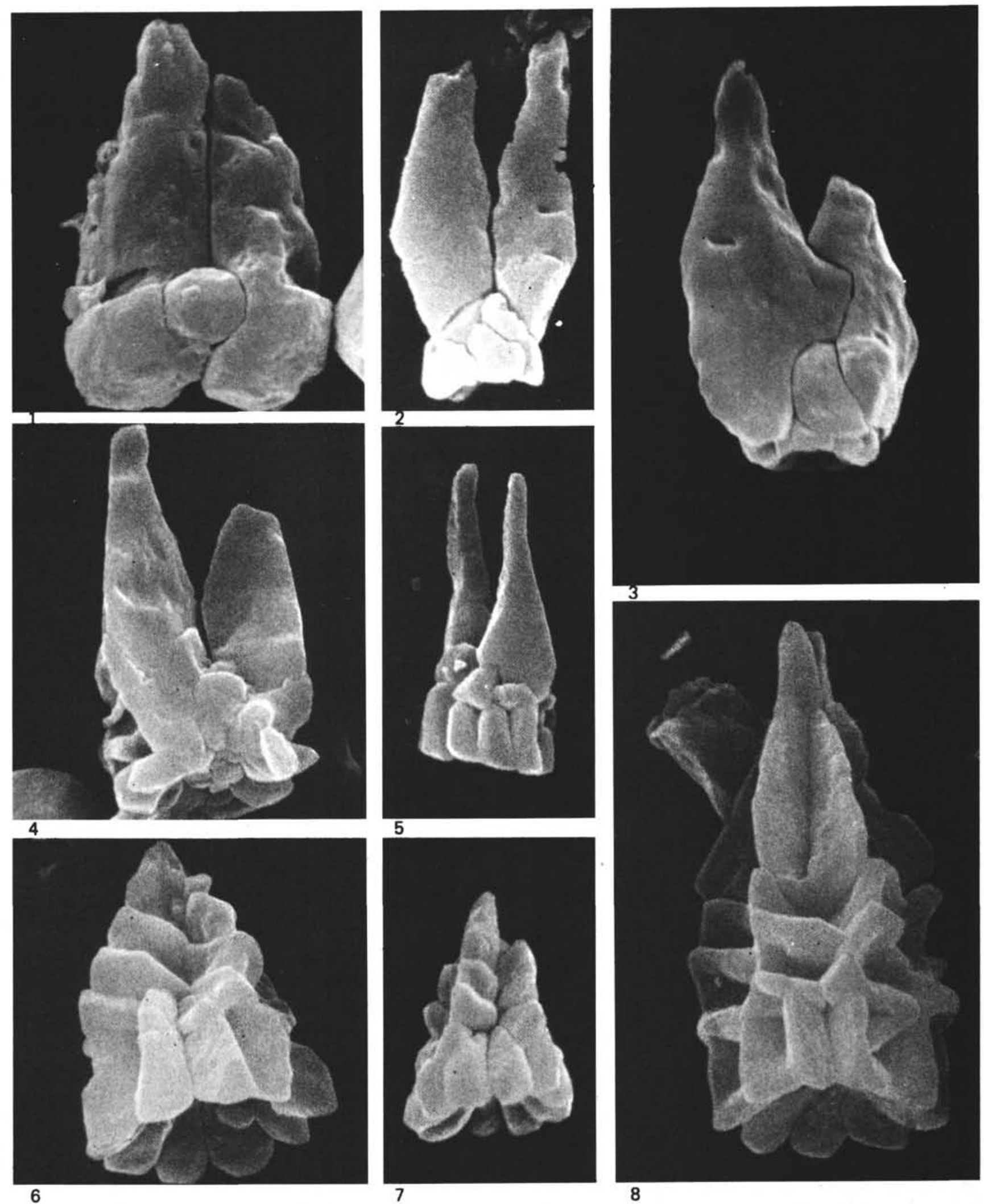


\section{PLATE 32}

Calcareous nannofossils from Sample 357-19, CC.

Magnification 16,000 $\times$ (Figure 1); $7200 \times$ (Figure 2);

9000× (Figures 3-7, 9-12); 6200× (Figure 8).

Figures 1-10 Sphenolithus predistentus Bramlette and Wilcoxon.

Figure 11 Sphenolithus moriformis (Brönnimann and Stradner) Bramlette and Wilcoxon.

Figure $12 \quad$ Sphenolithus sp. 1.

(see page 798)

\section{PLATE 33}

Calcareous nannofossils from Samples 357-17-1, $92 \mathrm{~cm}$

(Figures 1-3, 5-7); 357-14, CC (Figure 4); 354-10, CC

(Figures 8-11).

Magnification 11,000× (Figures 1-10); 8800× (Figure 11).

Figures 1-3, 5-7, Sphenolithus ciperoensis Bramlette and Wilcoxon. 10,11

Figures 4, 8 Sphenolithus dissimilis Bukry and Percival.

Figure 9 Sphenolithus distentus (Martini) Bramlette and Wilcoxon.

(see page 799)

\section{PLATE 34}

Calcareous nannofossils from Samples $357-6-5,70 \mathrm{~cm}$ (Figures 1-4) and 357-7-5, $70 \mathrm{~cm}$ (Figures 5-12).

Magnification $9000 \times$.

Figures 1,2 Sphenolithus conicus Bukry.

Figures 3,4 Sphenolithus heteromorphus Deflandre.

Figures 5-12 Sphenolithus belemnos Bramlette and Wilcoxon.

(see page 800) 
PLATE 32
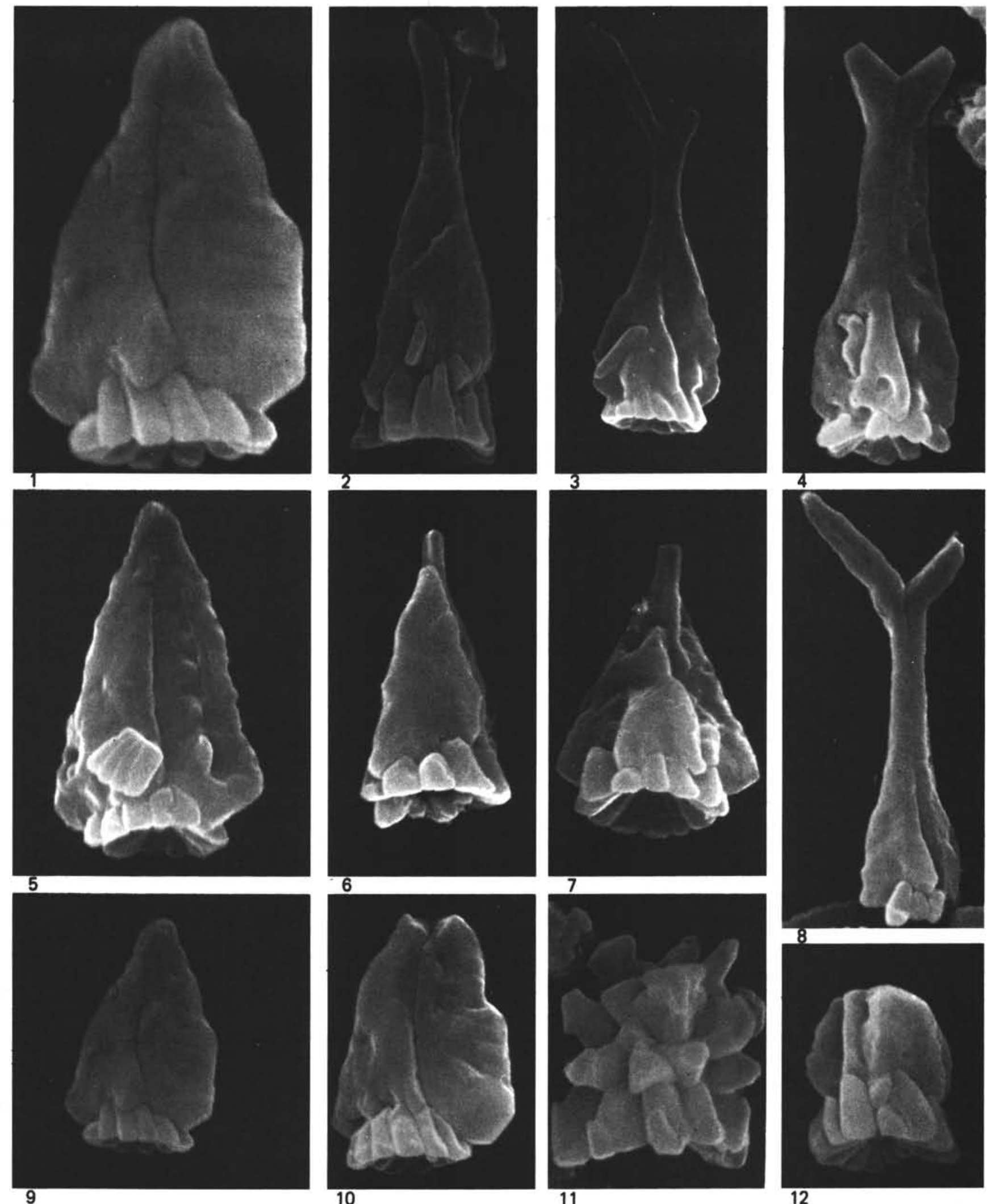
PLATE 33
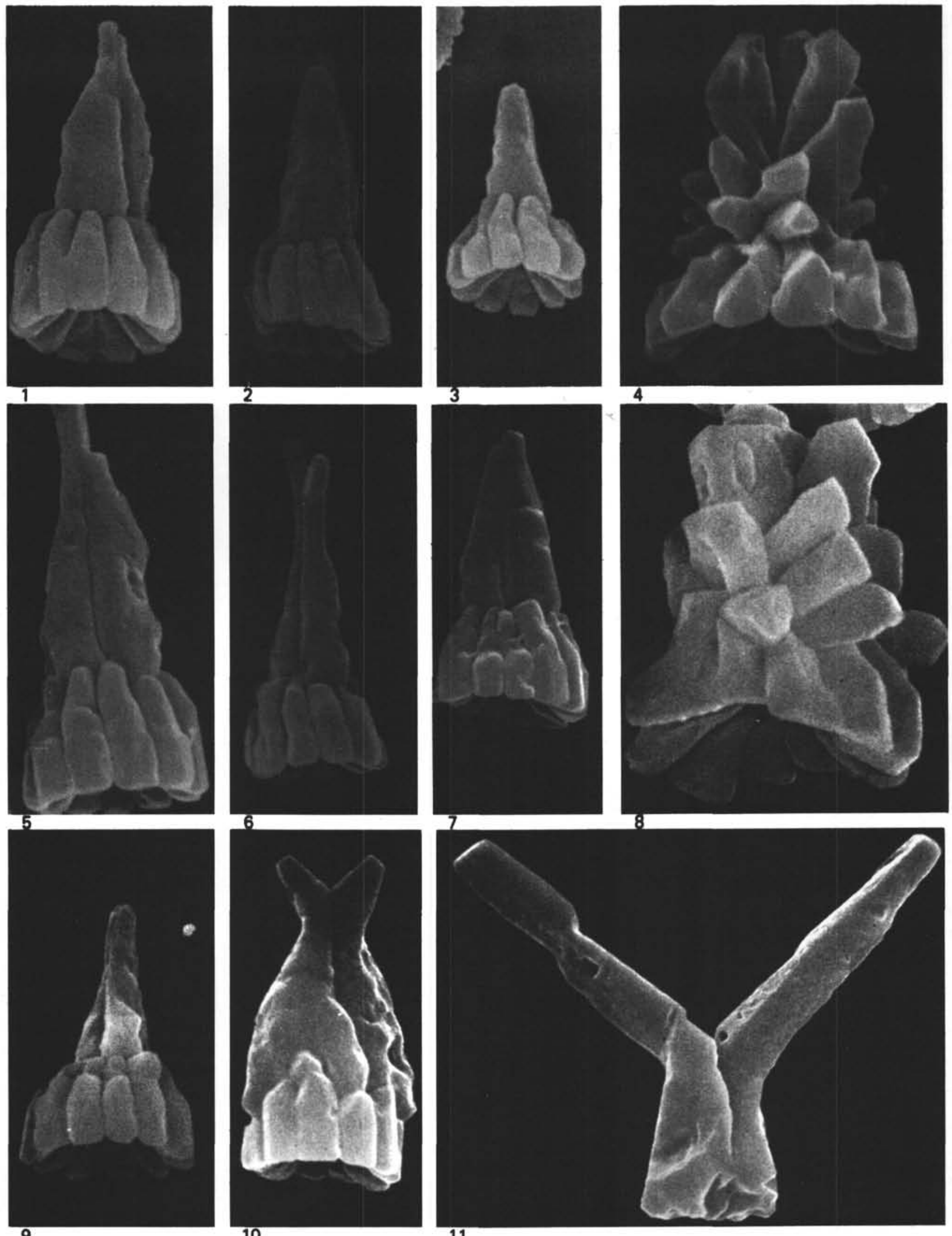
PLATE 34
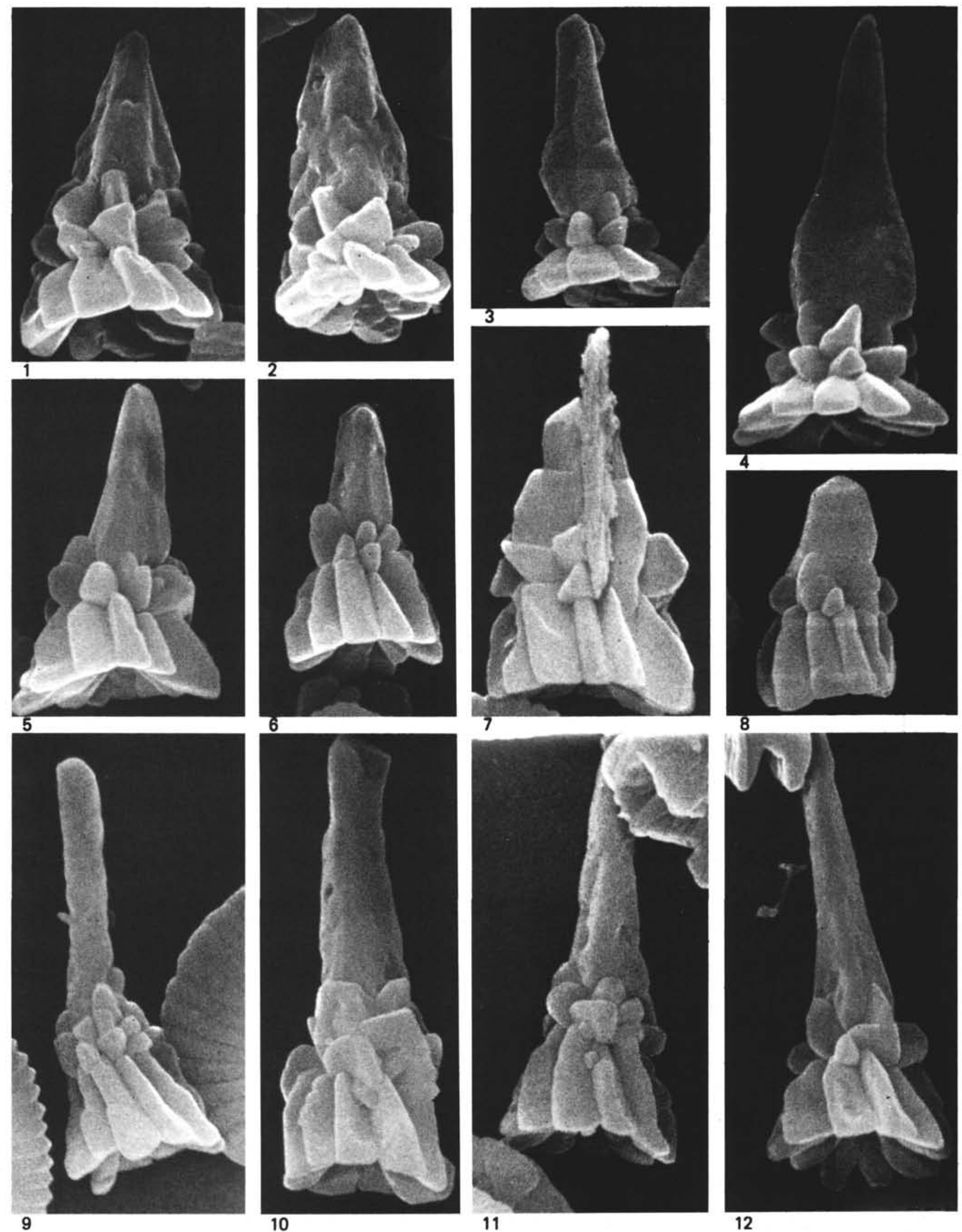
PLATE 35

Calcareous nannofossils from Sample 355-2, CC.

Magnification 7500× (Figures 1, 2, 5, 6, 9); $6800 \times$ (Figures 3, 10); 6000× (Figure 4); $5250 \times$ (Figures 7, 8).

Figures 1-4 Sphenolithus heteromorphus Deflandre.

Figures 5, 6, Sphenolithus conicus Bukry. 8-10

Figure $7 \quad$ Sphenolithus? sp. 2.

(see page 802 )

PLATE 36

Calcareous nannofossils from Samples 354-5, CC (Figures 1, 2); 356-4-6, $70 \mathrm{~cm}$ (Figures 3, 4, 7-11); 354-6-2, $25 \mathrm{~cm}$ (Figure 5); 356-5-2, $77 \mathrm{~cm}$ (Figure 6).

Magnification $4000 \times$ (Figures 1, 2); $5600 \times$ (Figure 3);

$8000 \times$ (Figures 4, 9, 10); 3200 $\times$ (Figure 5); 2900 $\times$ (Figure 6); $6400 \times$ (Figures 7, 8).

Figures 1,2,5 Triquetrorhabdulus rugosus Bramlette and Wilcoxon.

Figures 3, 7, 8, Triquetrorhabdulus challengeri n. sp. Holotype: 10, 11 Figure 3.

Figures 4, 9 Triquetrorhabdulus milowii Bukry.

Figure $6 \quad$ Triquetrorhabdulus carinatus Martini.

(see page 803 ) 


\section{PLATE 35}
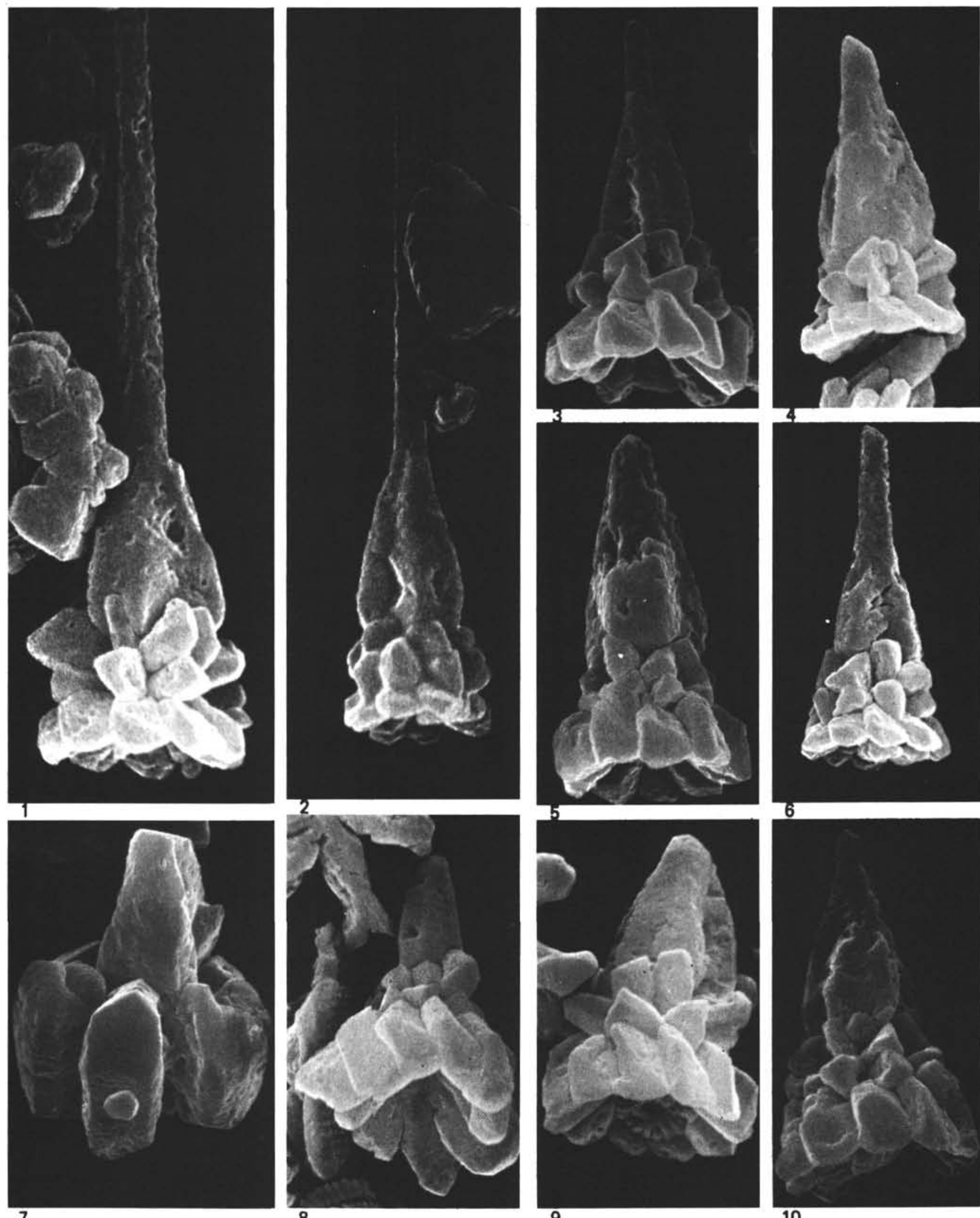

9 
PLATE 36
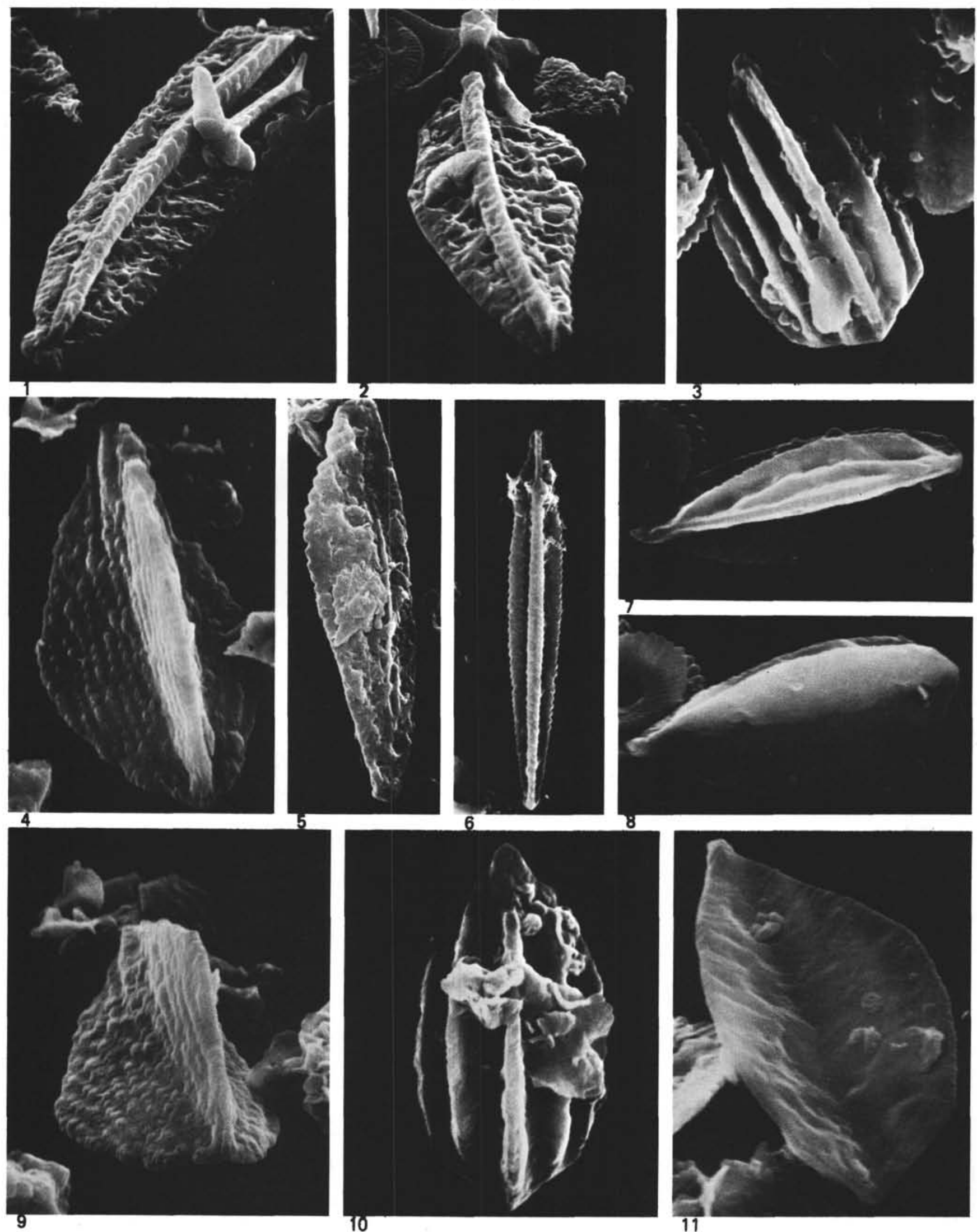


\section{PLATE 37}

Calcareous nannofossils from Samples 356-10-4, $70 \mathrm{~cm}$ (Figures 1, 8); 354-14-1, $55 \mathrm{~cm}$ (Figures 2-5); 356-10-1, $110 \mathrm{~cm}$ (Figures 6, 7); 357-28-6, $66 \mathrm{~cm}$ (Figures 9, 10); 357-20-1, $121 \mathrm{~cm}$ (Figure 11); 357-3-6, $70 \mathrm{~cm}$ (Figure 12); 356-7-3, $70 \mathrm{~cm}$ (Figures 13, 14); 357-14, CC (Figure 15).

Magnification $3750 \times$ (Figures 1, 3-5, 10, 14); 3000× (Figure 2); $5250 \times$ (Figure 6); 7500 $\times$ (Figures 7, 11-13, 15);

$15,000 \times$ (Figure 8); 4500 $\times$ (Figure 9).

Figures 1,8 Rhabdolithus perlongus Deflandre.

Figures 2-5 Pseudotriquetrorhabdulus inversus (Bukry and Bramlette) Wind \& Constanz.

Figures 6,7 ?; crystals, $\mathrm{HCl}$ soluble, containing $\mathrm{Ca}$; found here in the middle Eocene at Site 356. Also found in the Eocene of Denmark and the Southwest Pacific.

Figures 9, 10 Rhabdolithus inflatus (Bramlette and Sullivan) $\mathrm{n}$. comb. (Rhabdosphaera inflata Bramlette and Sullivan, 1961, p. 146, pl. 5, fig. 4, 5).

Figure $11 \quad$ Isthmolithus recurvus Deflandre.

Figure 12 Minylitha convallis Bukry.

Figures 13,14 Scyphosphaera (?) expansa Bukry and Percival.

Figure $15 \quad$ Zygrhablithus bijugatus (Deflandre) Deflandre.

\section{PLATE 38}

Calcareous nannofossils from Samples $356-23-2,70 \mathrm{~cm}$ (Figures 1-4); 356-25-5, $70 \mathrm{~cm}$ (Figures 5-8); 356-27-1, $70 \mathrm{~cm}$ (Figures 9-12); 356-28-3, $70 \mathrm{~cm}$ (Figures 13-16).

Magnification $9000 \times$.

Figures 1,2 Chiphragmalithus ? sp. 1.

Figures 3, 4, 8 Neochiastozygus distentus (Bramlette and Sullivan) Perch-Nielsen.

Figures 5,9 Neochiastozygus imbriei Haq and Lohmann.

Figures 6, 10, 12 Neochiastozygus perfectus Perch-Nielsen.

Figure $7 \quad$ Neochiastozygus sp. 1.

Figure $11 \quad$ Neochiastozygus modestus Perch-Nielsen.

Figures 13-16 Neochiastozygus sp. 2; early, irregular forms of the genus. 
PLATE 37
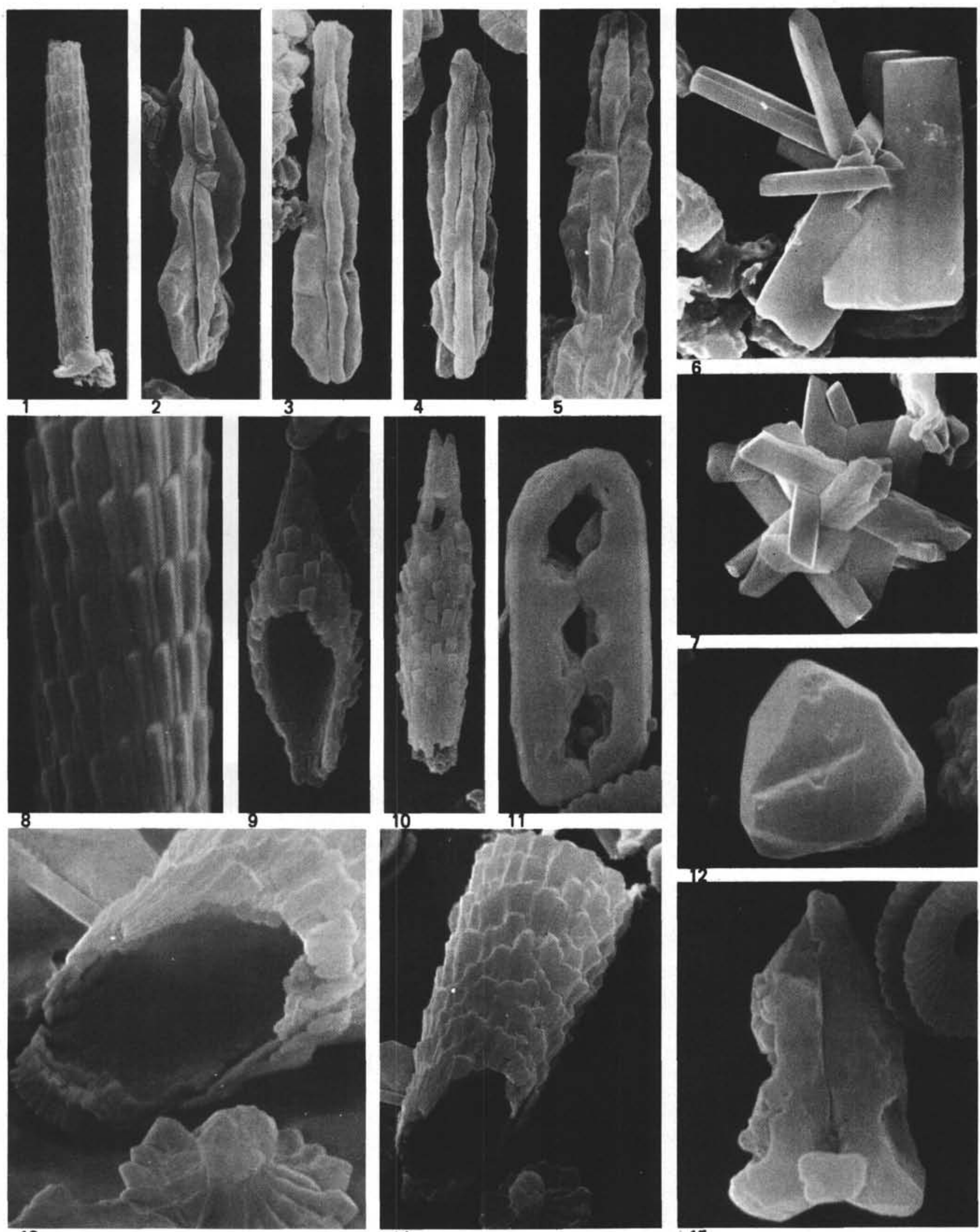

15 
PLATE 38
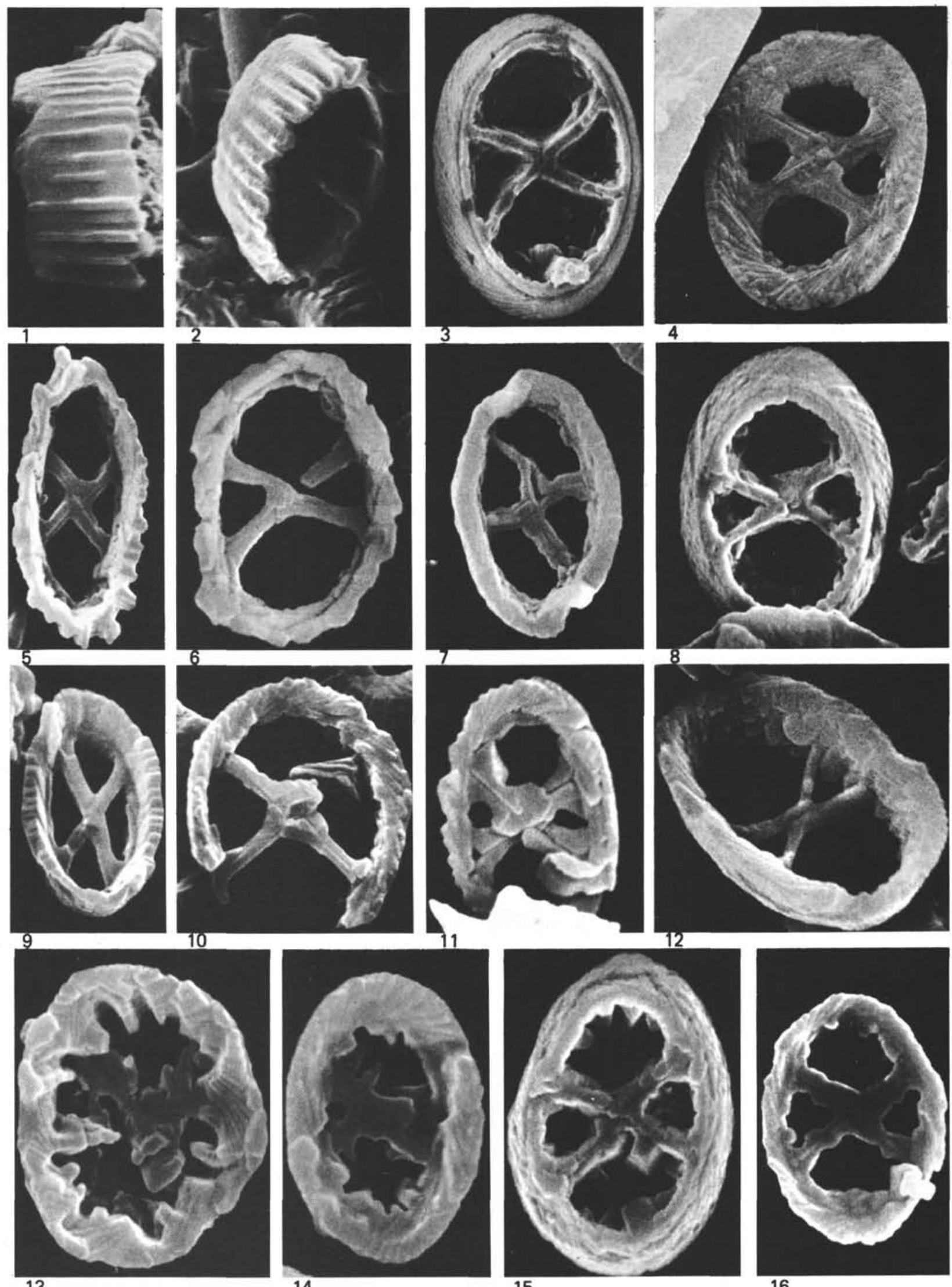


\section{PLATE 39}

Calcareous nannofossils from Samples 354-16-6, $90 \mathrm{~cm}$

(Figures 1, 4); 354-16-6, $120 \mathrm{~cm}$ (Figures 2, 5, 8); 354-16-6, $130 \mathrm{~cm}$

(Figures 3, 6, 9); 354-16-6, $100 \mathrm{~cm}$ (Figure 7).

Magnification $8500 \times$.

Figures 1, 3,4, Neochiastozygus modestus Perch-Nielsen. 6,9

Figures 2, 5, 8 Neochiastozygus distentus (Bramlette and Sullivan) Perch-Nielsen.

Figure 7 Neochiastozygus concinnus (Martini) PerchNielsen.

(see page 808 )

\section{PLATE 40}

Calcareous nannofossils from Samples 354-16-6, $40 \mathrm{~cm}$

(Figures 1-3); 354-16-6, $70 \mathrm{~cm}$ (Figures 4-6, 9, 10);

354-16-6, $90 \mathrm{~cm}$ (Figures 7, 8).

Magnification $8000 \times$ (Figures 1-4, 6-10); 5600× (Figure 5).

Figures 1-3 Neochiastozygus distentus (Bramlette and Sullivan) Perch-Nielsen.

Figures 4-6 Neochiastozygus cearae n. sp. Holotype: Figure 6.

Figures 7-10 Neochiastozygus modestus Perch-Nielsen.

(see page 809)

\section{PLATE 41}

Calcareous nannofossils from Samples 356-4-6, $70 \mathrm{~cm}$ (Figures 1, 2, 4, 5, 8); 355-2, CC (Figures 3, 6); 354-4, CC (Figure 7); 356-7-3, $70 \mathrm{~cm}$ (Figure 9); 354-4-3, $20 \mathrm{~cm}$ (Figure 10); 357-7-5, $70 \mathrm{~cm}$ (Figure 11); 357-10, CC (Figure 12); 357-20-1, $121 \mathrm{~cm}$ (Figure 13).

Magnification $7000 \times$ (Figures 1, 2, 4-13); 6700× (Figure 3).

Figures 1-6, 11, Coronocyclus nitescens (Kamptner) Bramlette and 12 Wilcoxon.

Figure $7 \quad$ Umbilicosphaera sp.

Figure $8 \quad$ Cyclococcolithina kingii (Roth) Roth.

Figure 9 Cyclococcolithina protoannula Gartner.

Figure 10 Hayella situliformis Gartner.

Figure 13 Coronocyclus prionion (Deflandre and Fert) Stradner. 
PLATE 39
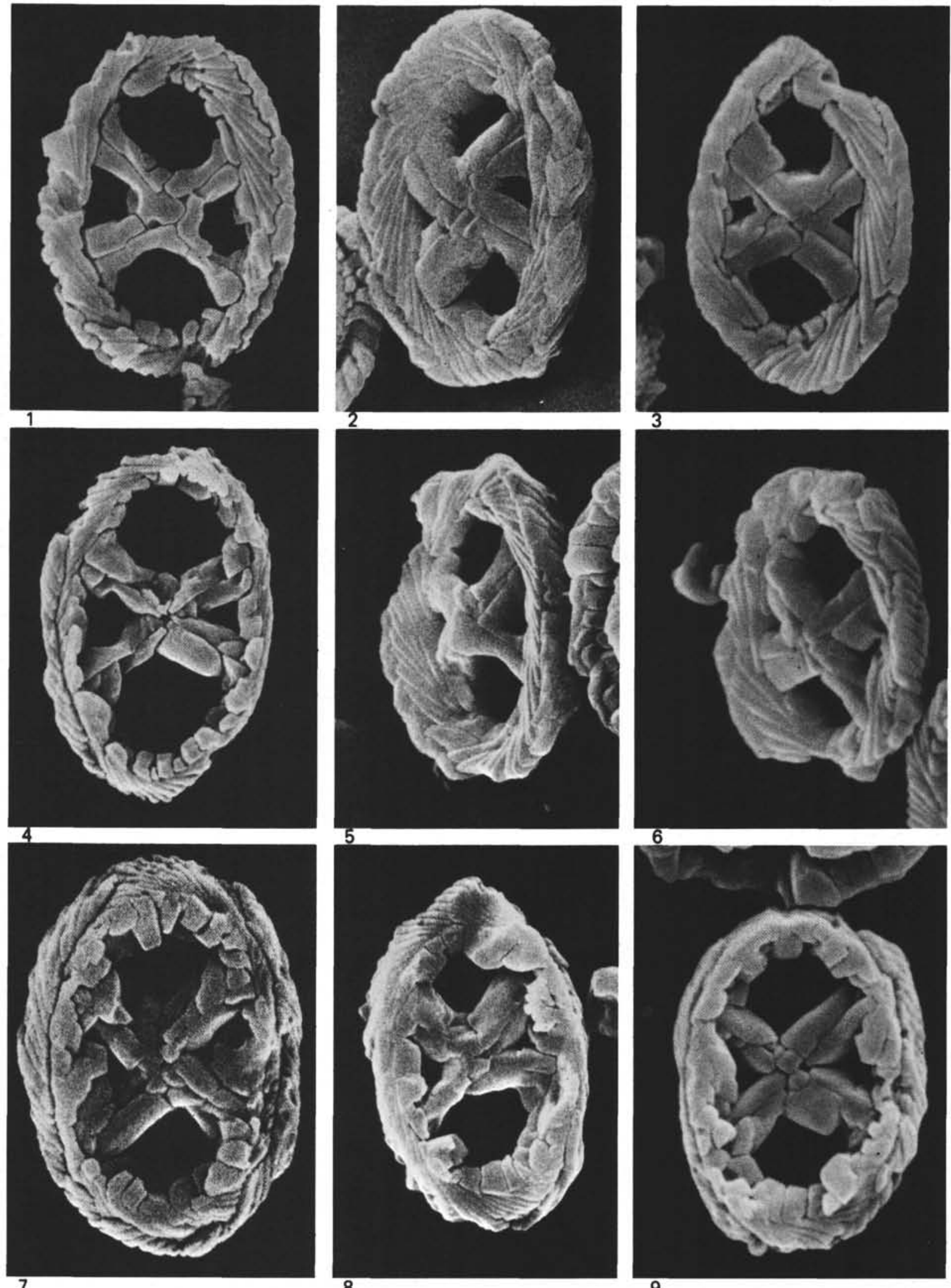

9 
PLATE 40
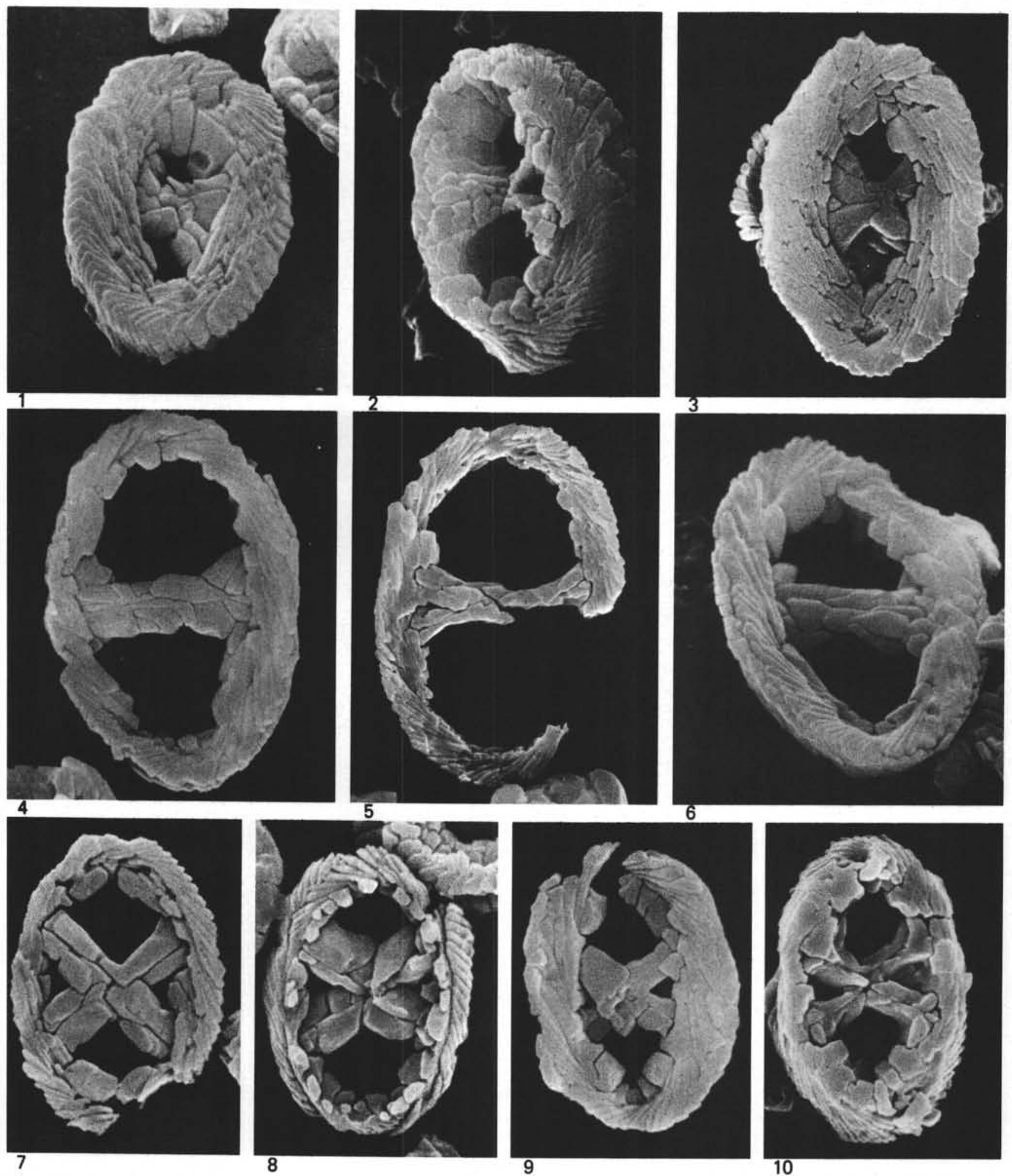


\section{PLATE 41}
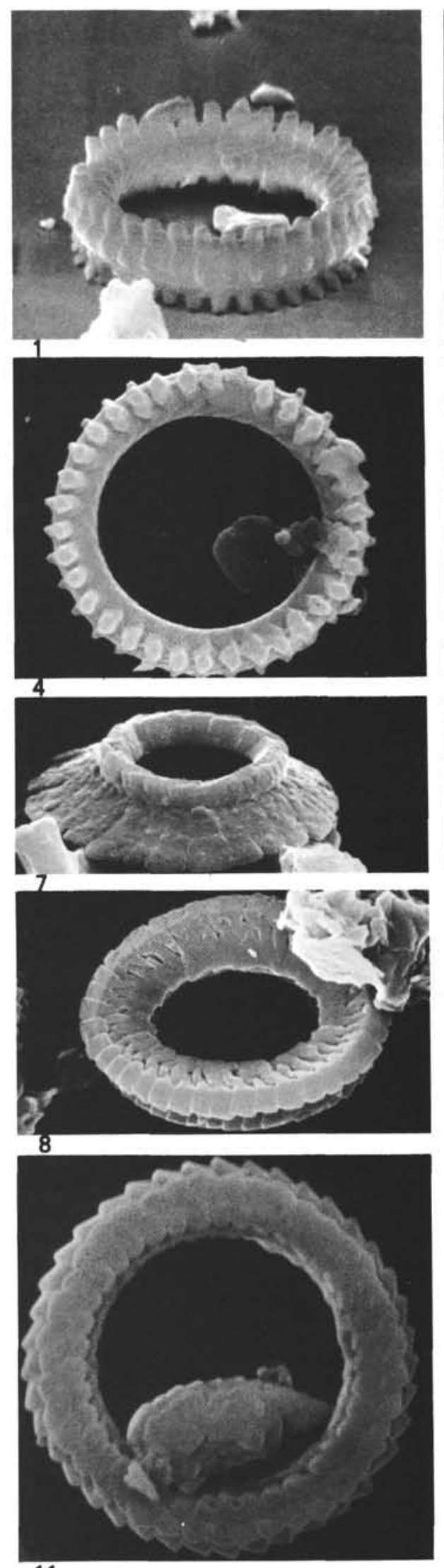
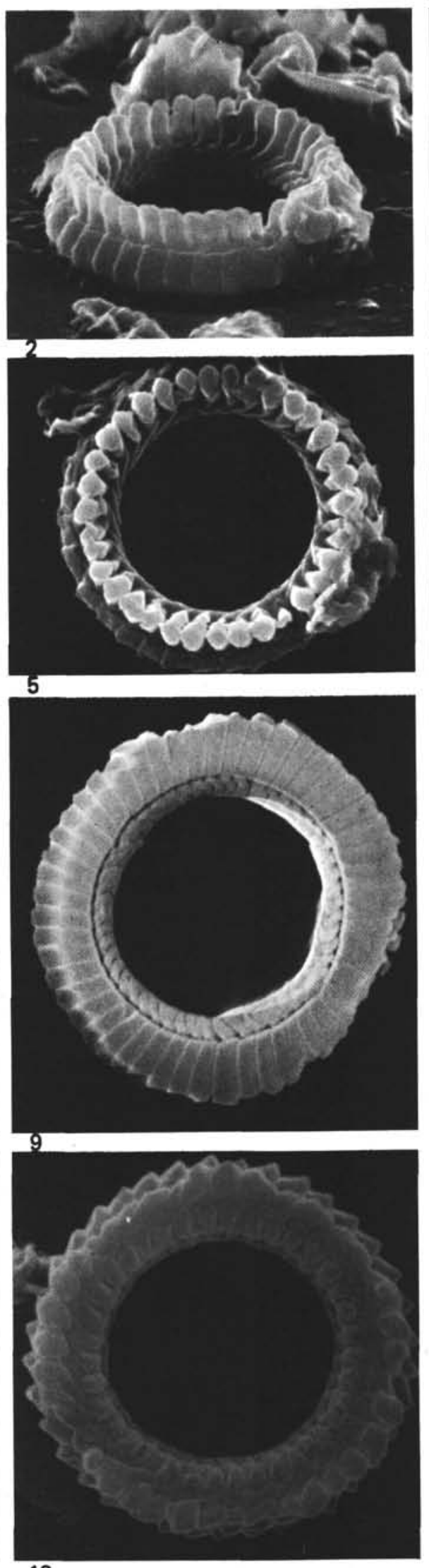
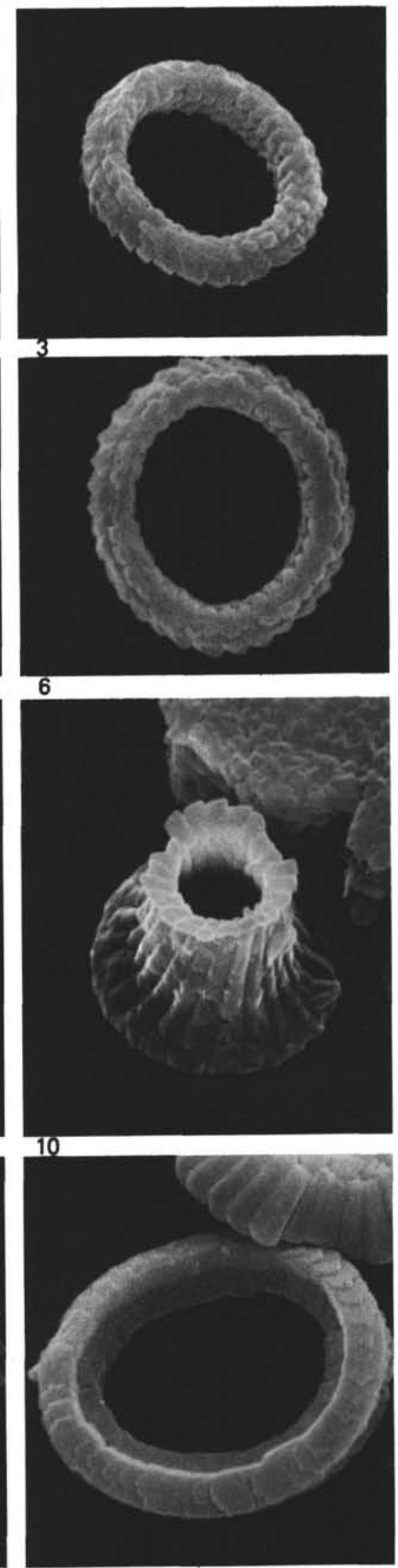
PLATE 42

Calcareous nannofossils from Sample 354-16-6, $40 \mathrm{~cm}$ (Figures 1, 2, 4); 354-16-6, $100 \mathrm{~cm}$ (Figures 3, 5); 354-16-6, $70 \mathrm{~cm}$ (Figure 6).

Magnification 6000× (Figures 1, 4); 6800× (Figures 2, 3, 5); $8500 \times$ (Figure 6).

Figures 1-6 Ellipsolithus macellus (Bramlette and Sullivan) Sullivan.

(see page 812 )

\section{PLATE 43}

Calcareous nannofossils from Samples 356-23-2, $70 \mathrm{~cm}$

(Figures 1-5, 7, 10); 356-25-5, $70 \mathrm{~cm}$ (Figure 6); 354-16-6, $70 \mathrm{~cm}$ (Figures 8, 9).

Magnification $8000 \times$ (Figures 1-7); 5600 $\times$ (Figures 8, 9);

$11,2000 \times$ (Figure 10).

Figures 1, 2, 4, 8 Ellipsolithus distichus (Bramlette and Sullivan) Sullivan.

Figures 3, 5-7 Ellipsolithus bollii n. sp. Holotype: Figure 3.

Figure9 Ellipsolithus macellus (Bramlette and Sullivan) Sullivan.

Figure 10 Syracosphaera? sp.

(see page 813)

\section{PLATE 44}

Calcareous nannofossils from Sample 357-20-1, $121 \mathrm{~cm}$.

Magnification $7500 \times$ (Figures 1, 3, 4, 6, 7); 6000× (Figure 2); $6800 \times$ (Figure 5).

Figures 1-7 Hayella situliformis Gartner.

(see page 814)

\section{PLATE 45}

Calcareous nannofossils from Samples 356-5-2, $77 \mathrm{~cm}$

(Figures 1, 8, 9) and 356-4-6, $70 \mathrm{~cm}$ (Figures 2-7, 10).

Magnification $12,000 \times$ (Figure 1); $7500 \times$

(Figures 2, 3, 5, 6, 9, 10); 11,200× (Figures 4, 7); 7000 $\times$ (Figure 8).

Figures 1,2 Dictyococcites abisectus (Müller) Bukry and Percival.

Figures 3, 6, 10 Hayella ? sp.

Figures 4, 7, 8, 9 Ilselithina fusa Roth.

Figure $5 \quad$ Syracosphaera ? sp. 


\section{PLATE 42}
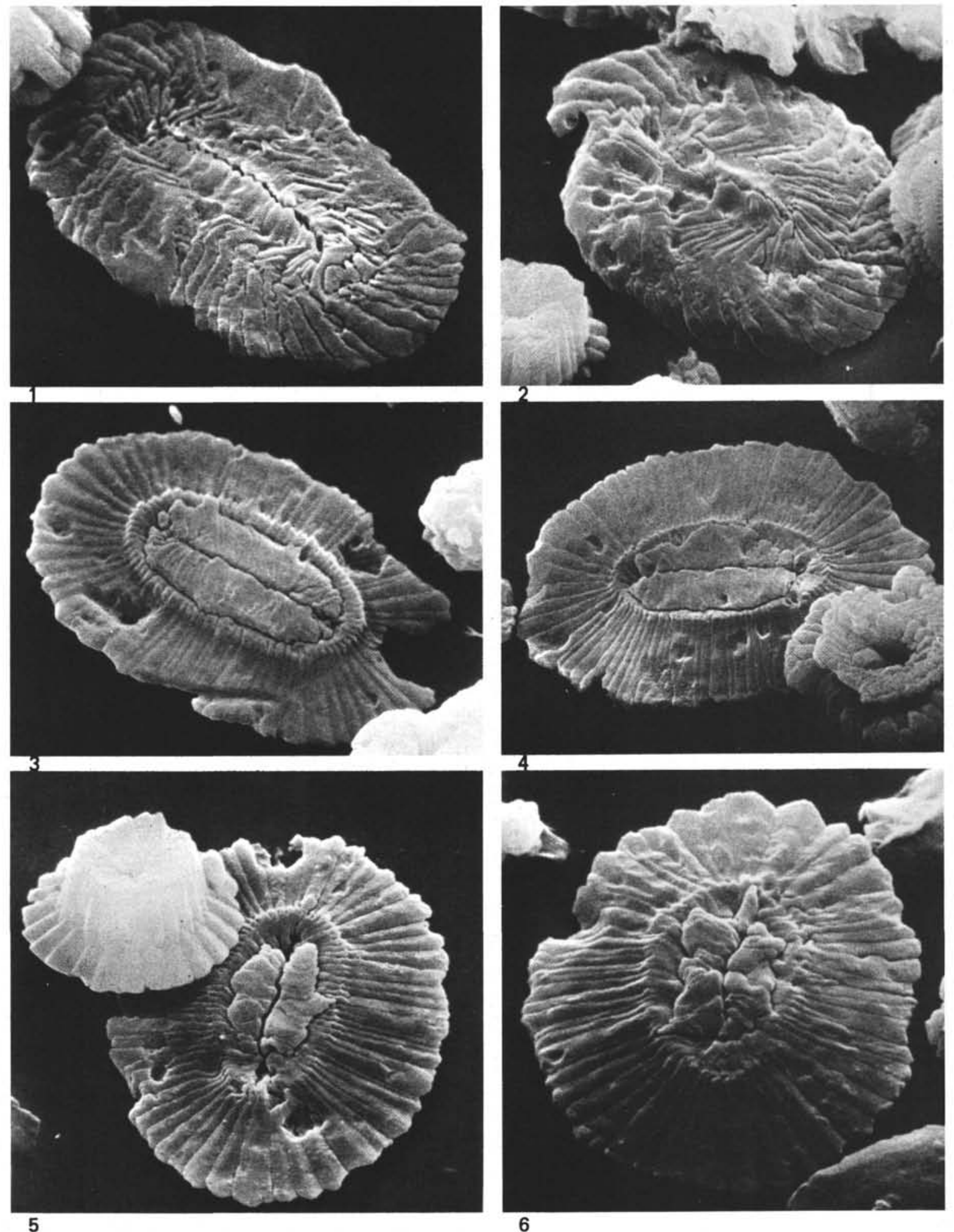
PLATE 43
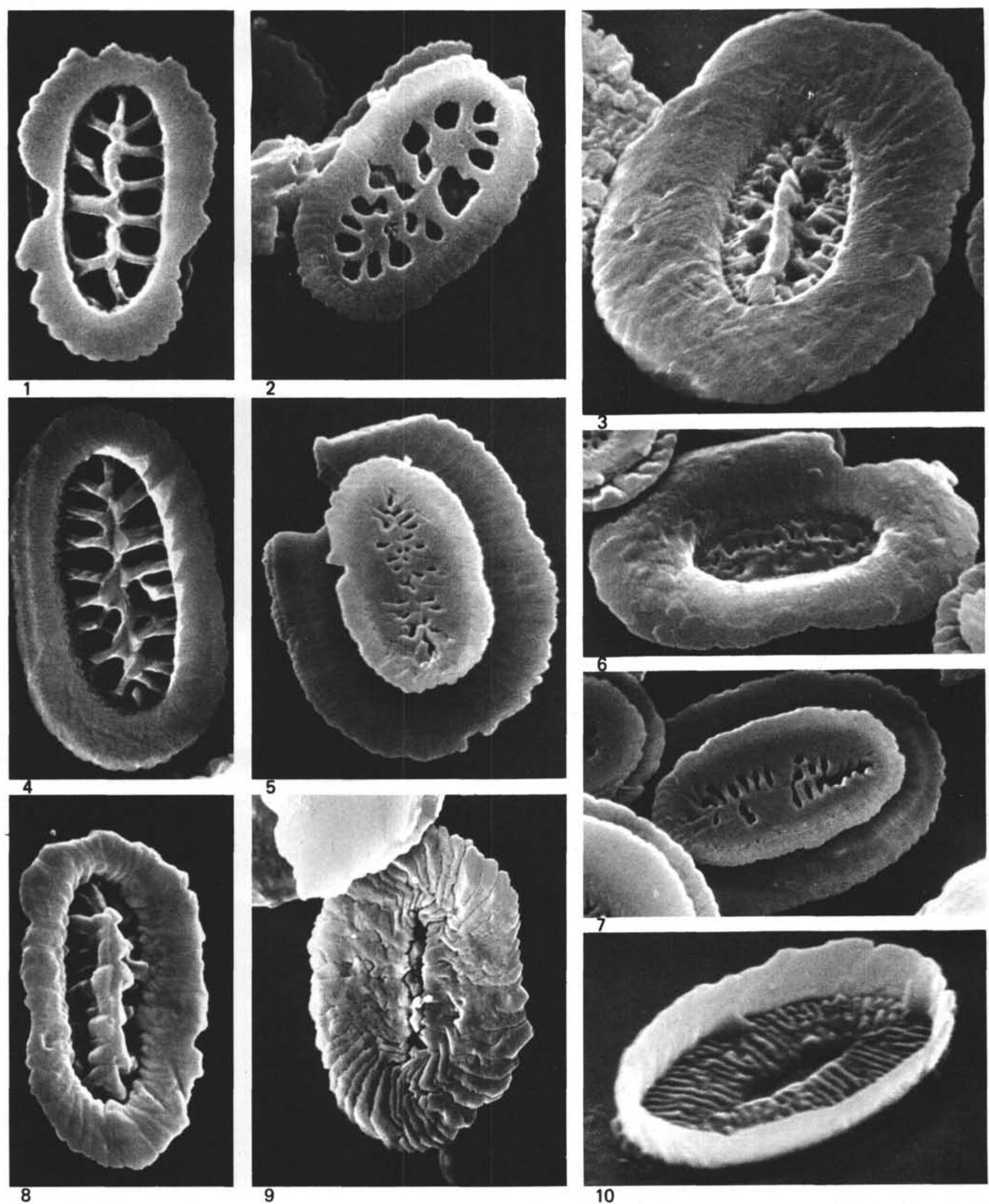
PLATE 44

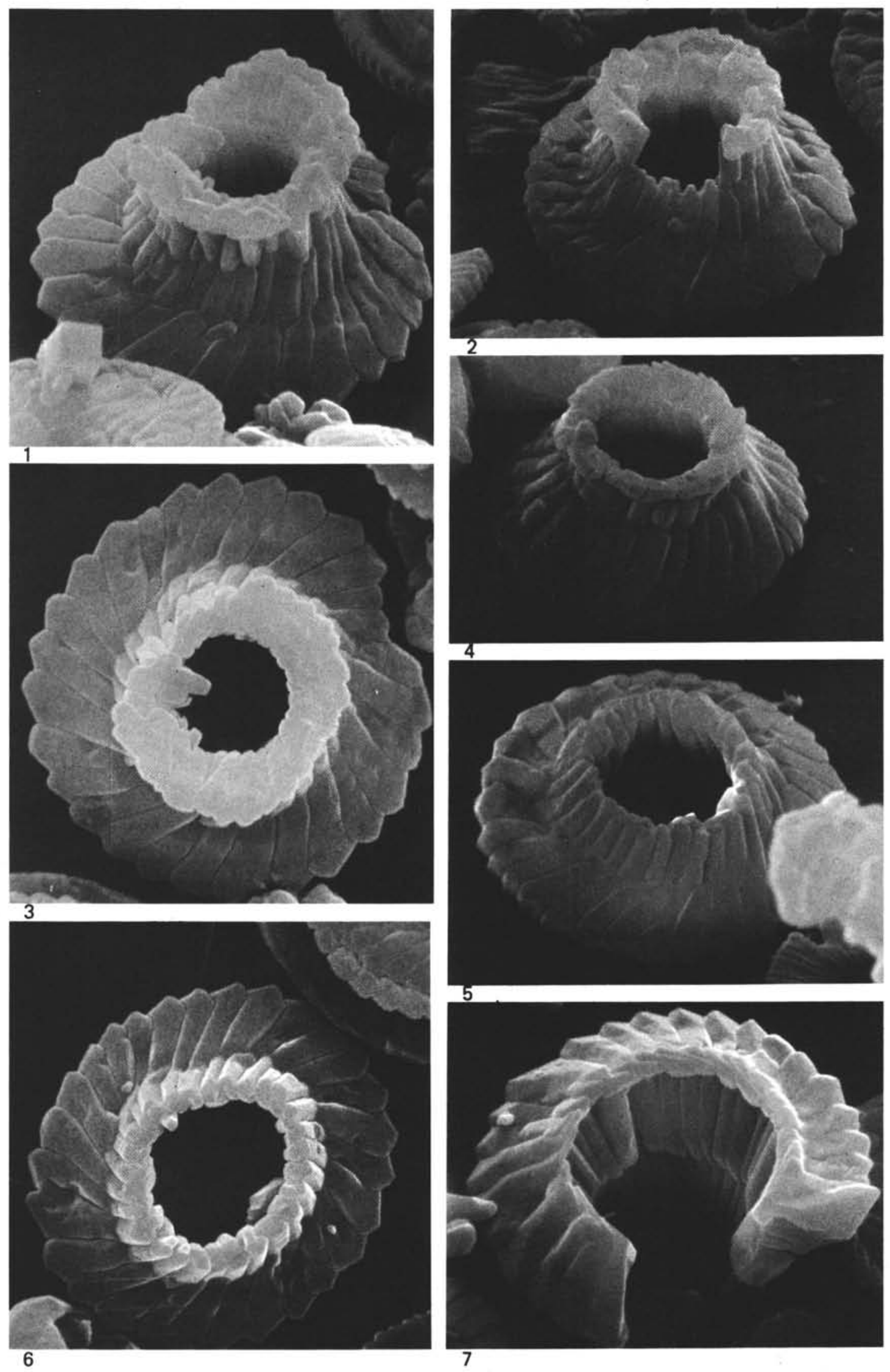


PLATE 45
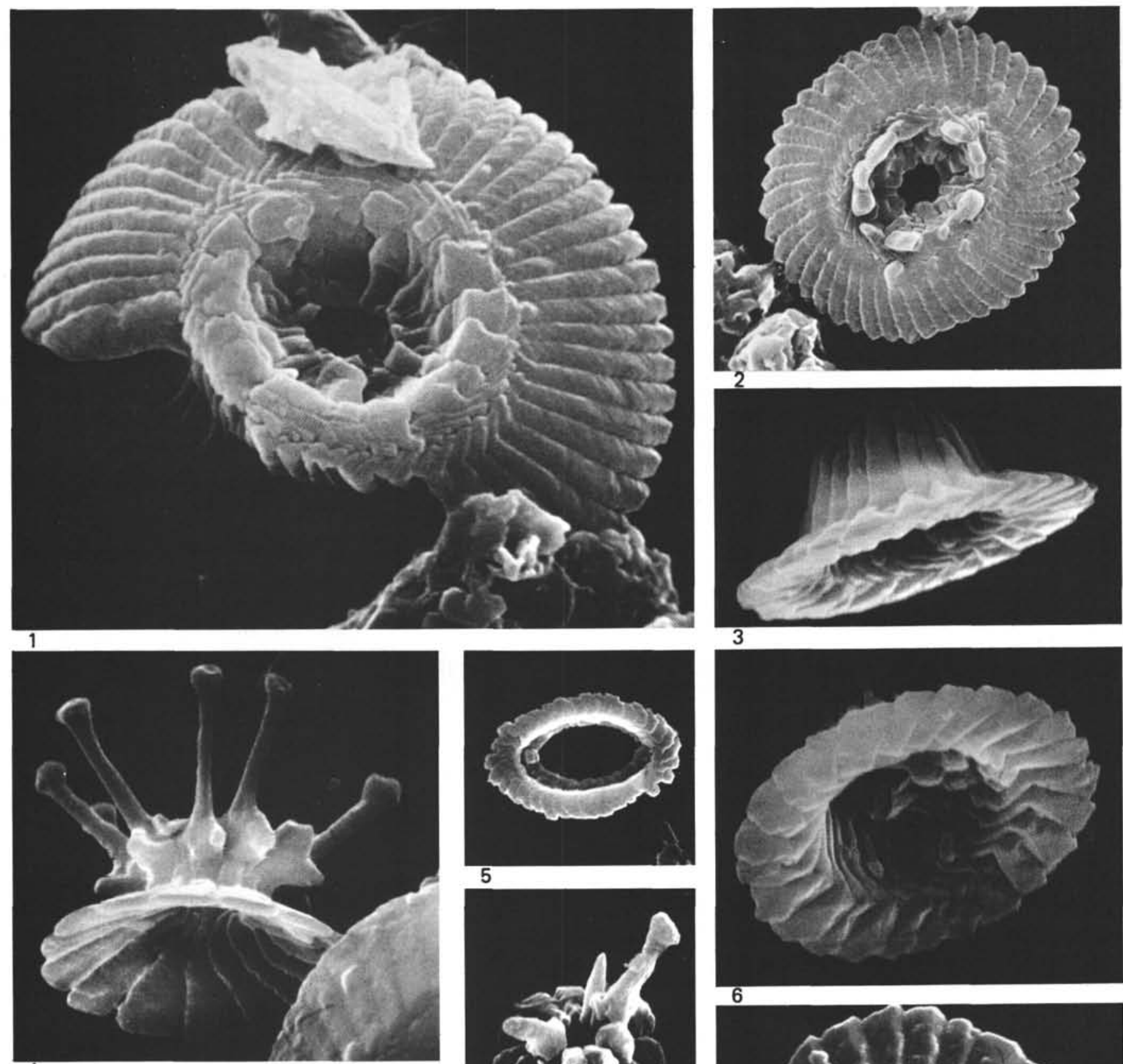

4
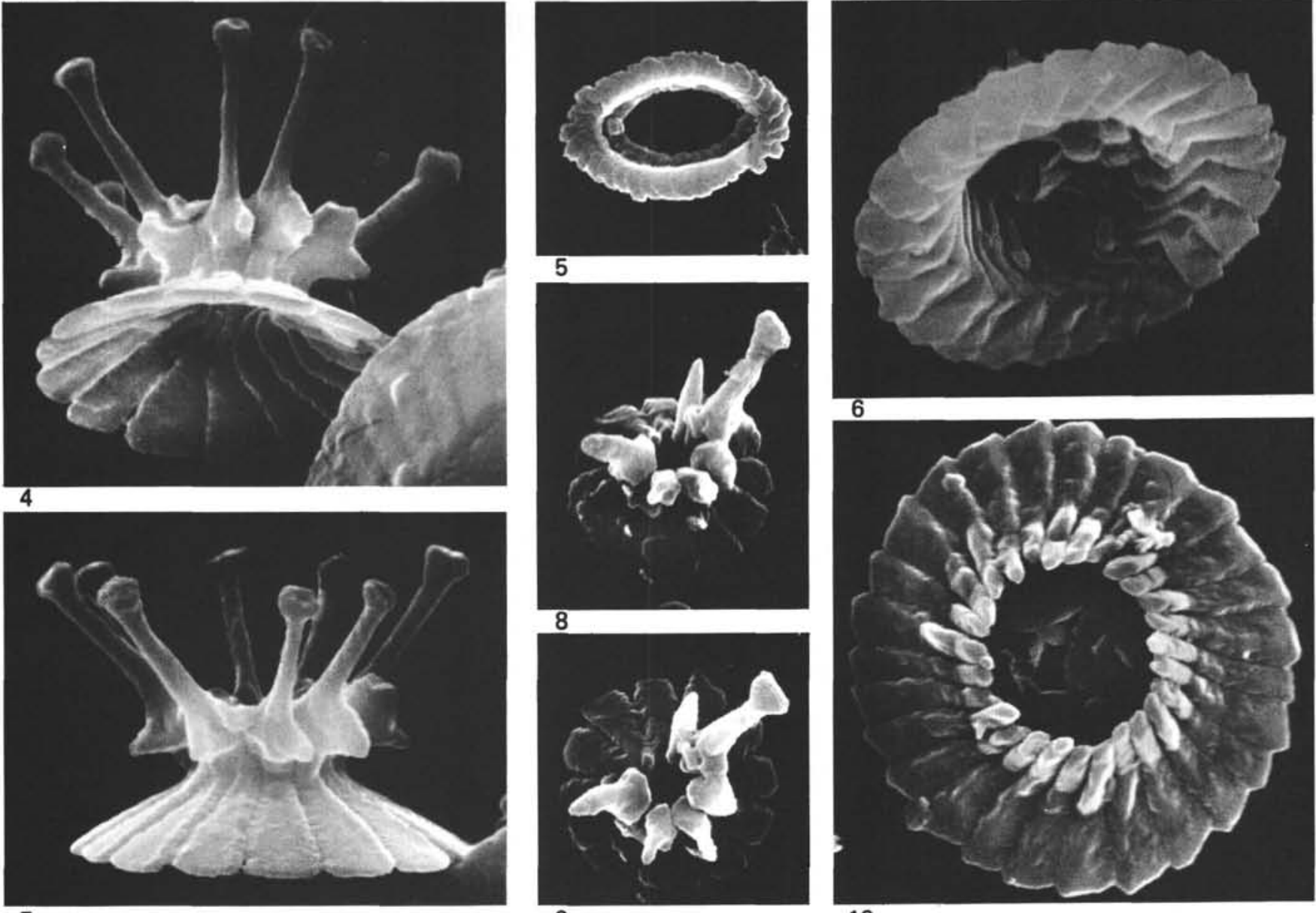

9

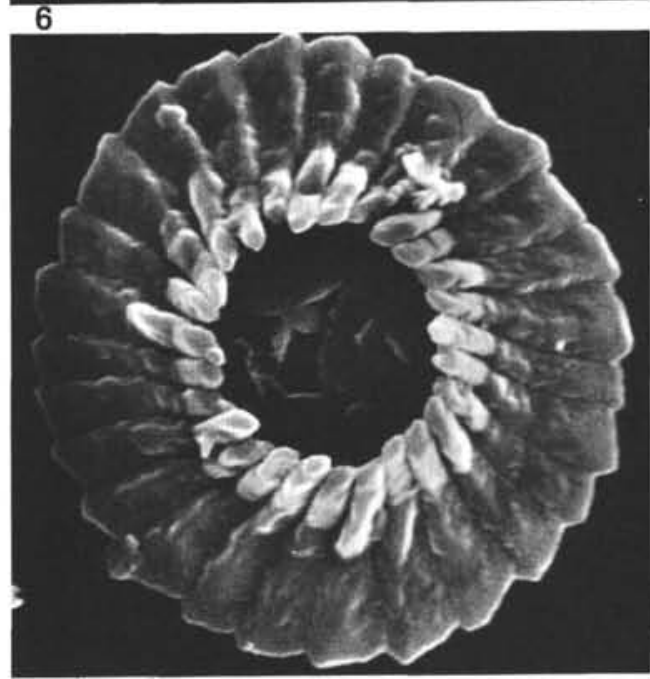




\section{PLATE 46}

Calcareous nannofossils from Samples 356-23-2, $70 \mathrm{~cm}$

(Figures 7-12); 356-27-1, $70 \mathrm{~cm}$ (Figures 1-4);

356-28-3, $70 \mathrm{~cm}$ (Figures 5, 6).

Magnification $8500 \times$ (Figures 1-6); 9000× (Figures 7-12).

Figures 1, 4, Hornibrookina teuriensis Edwards. $7-12$

Figures 2, 3, 5, 6 Hornibrookina edwardsii n. sp. Holotype: Figure 6.

\section{PLATE 47}

Calcareous nannofossils from Samples 356-7-3, $70 \mathrm{~cm}$

(Figures 1-9); 356-9-2, $70 \mathrm{~cm}$ (Figure 10);

$357-26-4,48 \mathrm{~cm}$ (Figures 11, 12).

Magnification 3250× (Figures 1-6, 9, 10); 4500× (Figures 7, 8, 11); $2900 \times$ (Figure 12).

Figures 1-12 Nannotetrina cristata (Martini) Perch-Nielsen.

(see page 818 )

\section{PLATE 48}

Late Cretaceous calcareous nannofossils from Samples 357-31-1,

$116 \mathrm{~cm}$ (Figures 1, 2, 9, 17, 18, 20); 356-31-3, $69 \mathrm{~cm}$

(Figures 4-6, 13); 357-34-1, $70 \mathrm{~cm}$ (Figures 7, 8, 10-12,

$16,19,21) ; 356-35-2,70 \mathrm{~cm}$ (Figures 14, 15); 356-27-1, $70 \mathrm{~cm}$

(Figure 3, reworked ? in lower Paleocene).

Magnification $6000 \times$ (Figures 1-7, 9-11, 13-21); 4800×

(Figures 8, 12).

Figures 1-3 Micula mura (Martini) Bukry.

Figure $4 \quad$ Lithraphidites quadratus. Bramlette and Martini.

Figure $5 \quad$ Micula sp.

Figures 6,7 Tetralithus aculeus (Stradner) Gartner.

Figures 8, 12, 16 Tetralithus trifidus (Stradner) Bukry.

Figures 9, 10 Micula staurophora (Gardet) Stradner.

Figure 11 Tetralithus gothicus Deflandre.

Figures 13, 17, Cribrocentrum gallica (Stradner) Perch-Nielsen. 18

Figures 14, 15 Marthasterites furcatus Deflandre.

Figures 19-21 Cylindralithus serratus Bramlette and Martini. 


\section{PLATE 46}
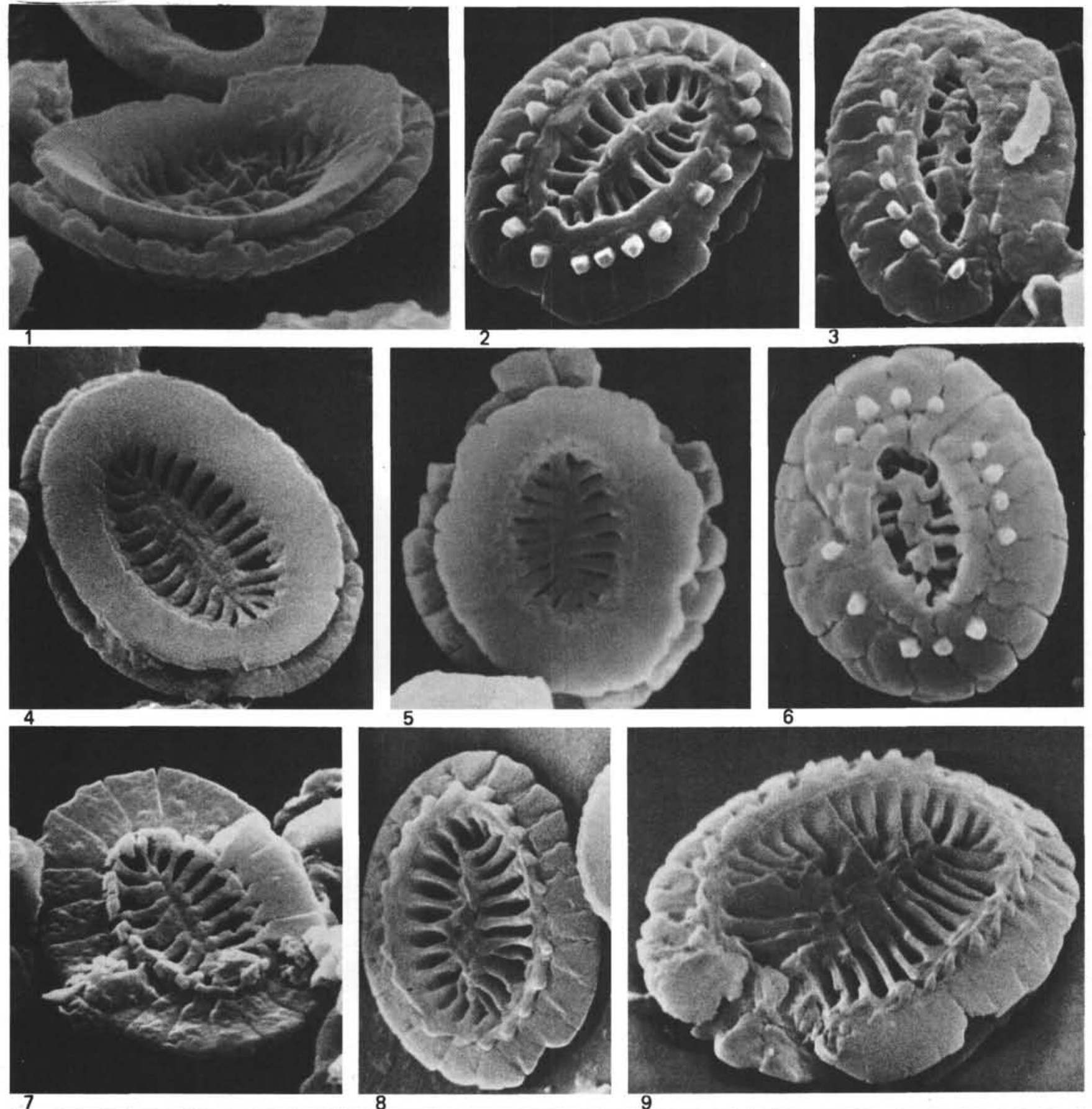

5
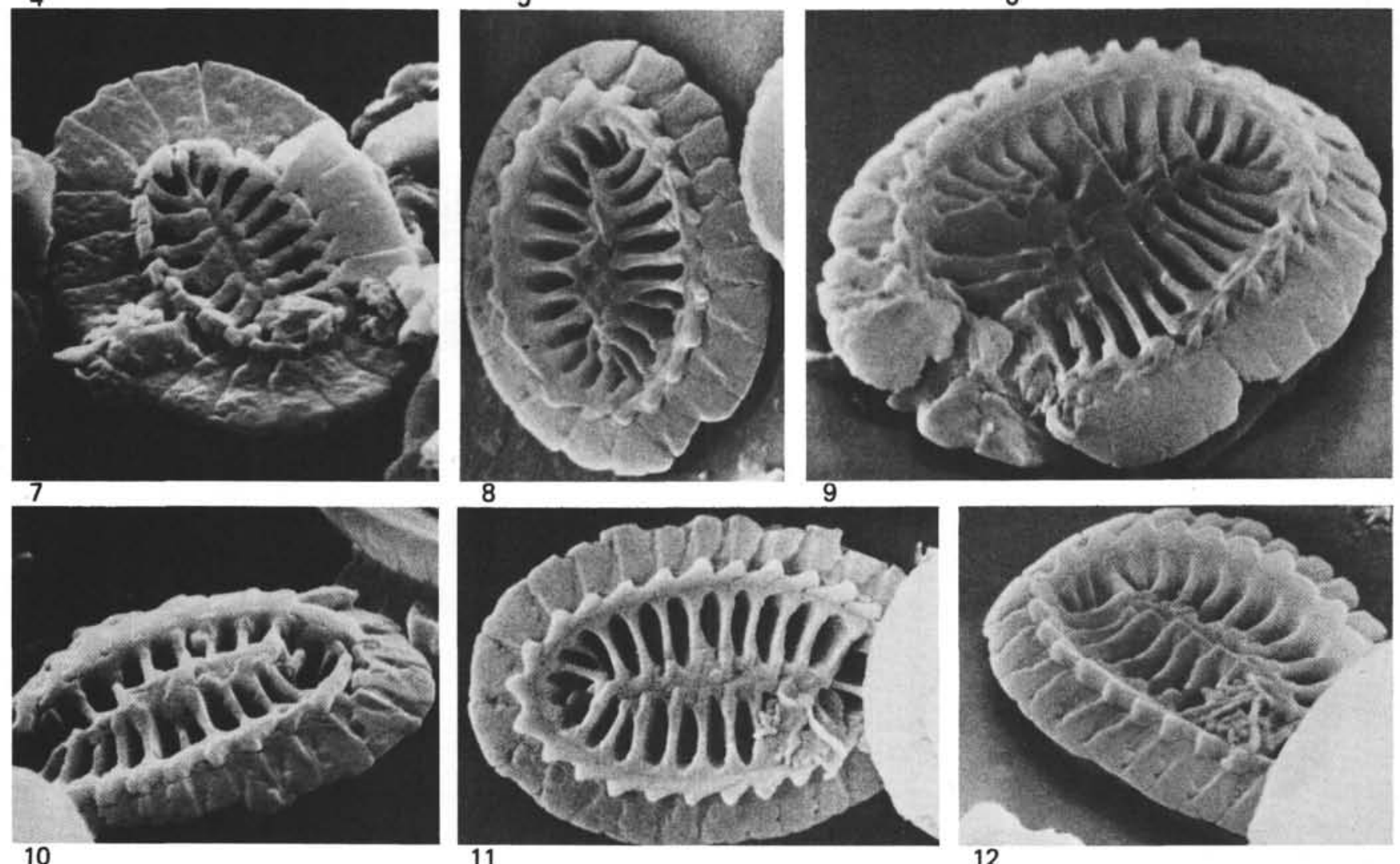
PLATE 47
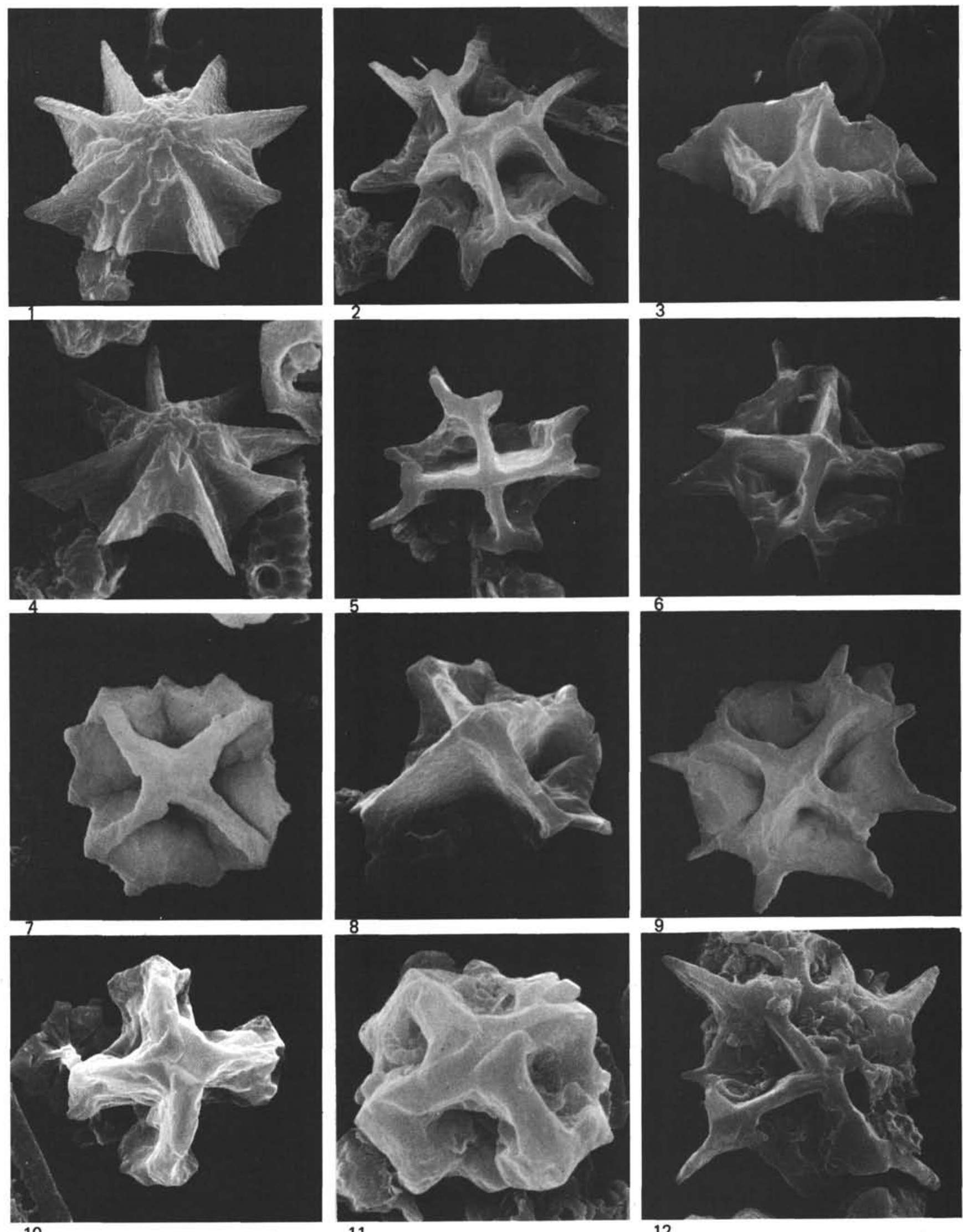
ALBIAN TO PLEISTOCENE CALCAREOUS NANNOFOSSILS

\section{PLATE 48}

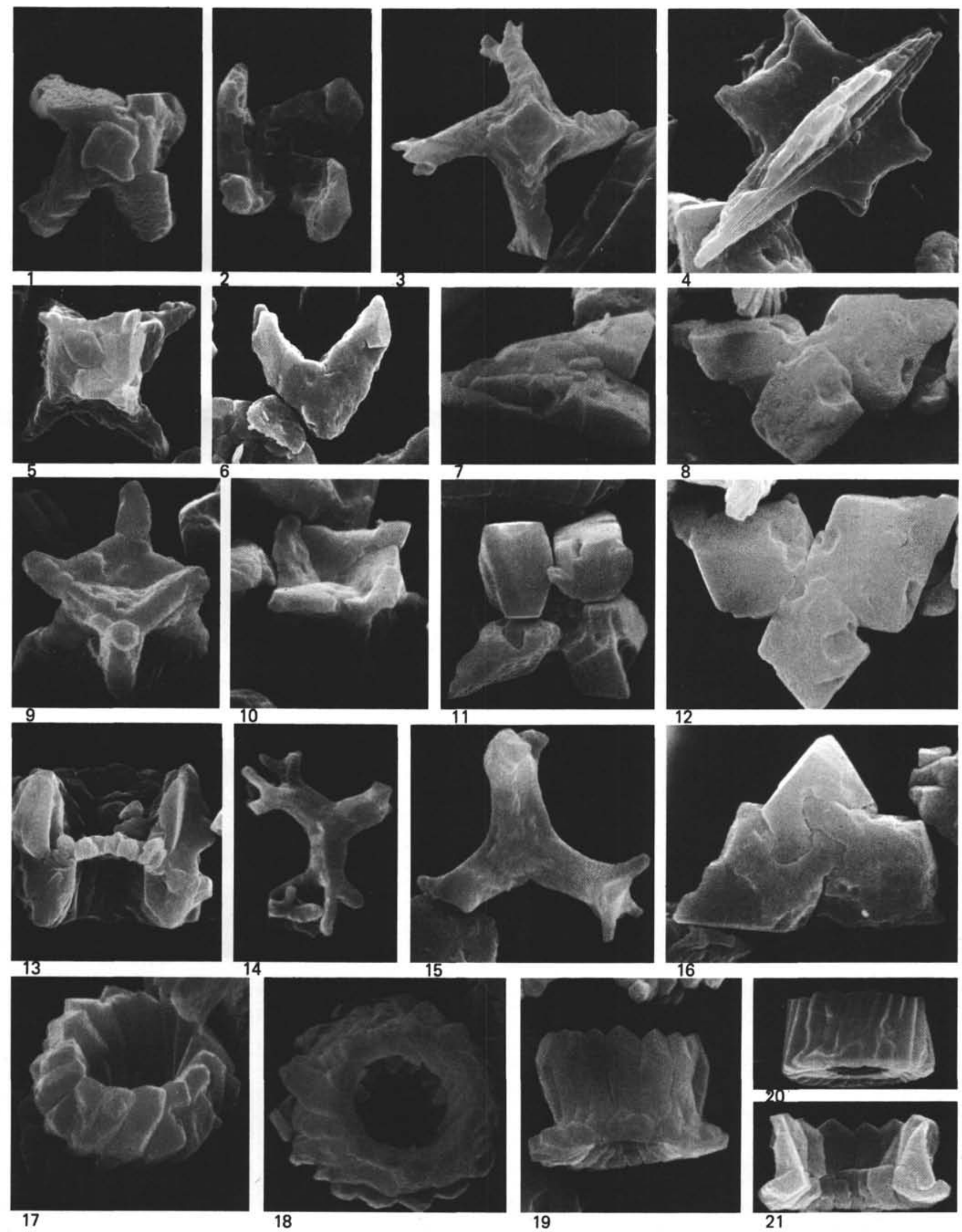




\section{PLATE 49}

LM photographs of calcareous nannofossils; magnification ca. 2000X.

Figure 1 Triquetrorhabdulus challengeri n. sp., crossed nicols, $45^{\circ}$. Sample $356-4-6,70 \mathrm{~cm}$.

Figures 2-4 Ceratolithus atlanticus n. sp., crossed nicols, $45^{\circ}$. Sample 354-4, CC.

Figure $5 \quad$ Amaurolithus ninae n. sp. Sample 354-4, CC.

Figures 6-8 Ellipsolithus bollii $\mathrm{n}$. sp. Sample 356-23-2, $70 \mathrm{~cm}$.

Figures 9, 15 Neochiastozygus cearae n. sp. Sample 354-16-6, 70 $\mathrm{cm}$.

Figures 10, 16, Fasciculithus magnus Bukry and Percival; rela22 tively flat and relatively high specimens from Sample 356-25-5, $70 \mathrm{~cm}$.

Figure $11 \quad$ Ellipsolithus distichus (Bramlette and Sullivan) Sullivan. Sample $356-23-2,70 \mathrm{~cm}$.

Figures 12-14 Ellipsolithus macellus (Bramlette and Sullivan) Sullivan. Sample 354-16-6, $90 \mathrm{~cm}$.

Figures 17-19 Lapideacassis sp.

17, 18. Sample $356-23-2,70 \mathrm{~cm}$.

19. Sample $356-29-1,90 \mathrm{~cm}$.

Figures 20,21 Neochiastozygus imbriei Haq and Lohmann. Sample 356-27-1, $70 \mathrm{~cm}$.

Figures 23-25 Fasciculithus ulii Perch-Nielsen. Sample 356-24-3, $20 \mathrm{~cm}$.

Figure 26 Fasciculithus janii Perch-Nielsen. Sample 356-23-2, $70 \mathrm{~cm}$.

Figures 27-29 Fasciculithus cf. F. billii Perch-Nielsen. Sample $356-18-1,69 \mathrm{~cm}$.

Figures 30-32 Sphenolithus ? sp. Sample 356-18-2, $70 \mathrm{~cm}$ (or $P$. spinosus?).

Figures 33, Sphenolithus sp. 1. Sample 356-7-1, $70 \mathrm{~cm}$. $42-44$

Figures 34-39 Hornibrookina teuriensis Edwards. 34,35 . Sample $356-23-2,70 \mathrm{~cm}$. 36-39. Sample $354-16-6,120 \mathrm{~cm}$.

Figures 40,41 Hornibrookina edwardsii n. sp. Sample 356-28-3, $70 \mathrm{~cm}$.

Figures 45-47, Rhabdolithus sp. 1. Sample 356-9-2, $70 \mathrm{~cm}$ 50-53 (Eocene).

Figures 48,49, Rhabdolithus sp. 2. Sample 356-8-1, $70 \mathrm{~cm}$ 54

(Eocene). 
PLATE 49

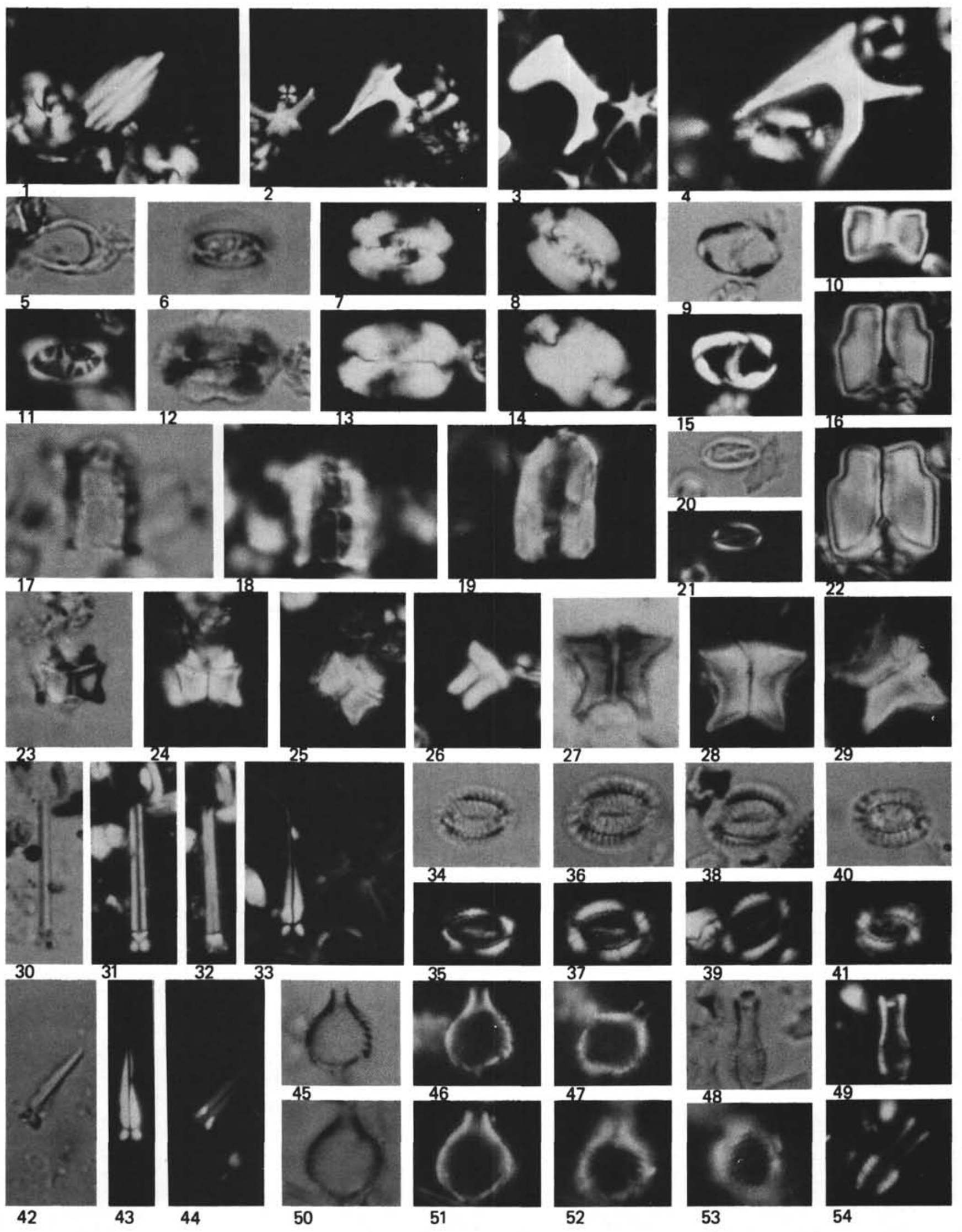




\section{PLATE 50}

LM photographs of calcareous nannofossils; magnification ca. 2000X. Paleocene.

Figure 1 Cruciplacolithus subrotundus Perch-Nielsen. Sample $356-25-5,70 \mathrm{~cm}$.

Figure 2 Cruciplacolithus notus n. sp. Sample 356-28-3, 70 $\mathrm{cm}$.

Figures 3,4 Cruciplacolithus tenuis (Stradner) Hay and Mohler. Sample 354-16-6, $120 \mathrm{~cm}$.

Figures 5, 6 Chiasmolithus frequens $\mathrm{n}$. sp. Sample 354-16-6, 120 $\mathrm{cm}$.

Figures 7,8 Chiasmolithus consuetus (Bramlette and Sullivan) Hay and Mohler. Sample 354-16-6, $120 \mathrm{~cm}$.

Figures 9,10 Chiasmolithus californicus (Sullivan) Hay and Mohler. Sample 354-16-6, $120 \mathrm{~cm}$.

Figures 11, 12 Cruciplacolithus primus n. sp. Sample 356-29-1, 90 $\mathrm{cm}$.

Figures 13, 14 Markalius inversus (Deflandre) Bramlette and Martini, large specimen. Sample 356-23-2, $70 \mathrm{~cm}$.

Figures 15-20 Markalius variabilis n. sp., specimens of varying size.

$15,16,19,20$. Sample $354-16-6,120 \mathrm{~cm}$.

17 , 18. Sample $354-16-6,130 \mathrm{~cm}$.

Figure $21 \quad$ Heliolithus kleinpellii Sullivan, small specimen. Sample 354-16-6, $90 \mathrm{~cm}$.

Figure 22 Ericsonia subpertusa Hay and Mohler. Sample $356-23-2,70 \mathrm{~cm}$.

Figure 23 Ericsonia robusta (Bramlette and Sullivan) $\mathrm{n}$. comb. Sample 356-23-2, $70 \mathrm{~cm}$.

Figures 24, 25 Heliolithus sp. Sample 354-16-6, $90 \mathrm{~cm}$.

Figures 26, 27 Heliolithus cf. H. cantabriae Perch-Nielsen. Sample 356-18-1, $69 \mathrm{~cm}$.

Figures 28, 29 Heliolithus conicus ? Perch-Nielsen. Sample 354$16-6,90 \mathrm{~cm}$.

Figures 30-33 Discoasteroides cf. D. bramlettei Bukry and Percival. Proximal and side views.

30, 31. Sample 354-16-6, $90 \mathrm{~cm}$.

32 , 33. Sample 354-16-1, $40 \mathrm{~cm}$.

Figures 34, 35 Ericsonia cf. E. robusta (Bramlette and Sullivan) n. comb.

Figures 36-38 Biantholithus sp. 1. Note the two flat, superimposed "shields." Sample 356-28-3, $70 \mathrm{~cm}$.

Figure 39 Scampanella sp. Sample 356-9-2, $70 \mathrm{~cm}$ (middle Eocene). 
PLATE 50
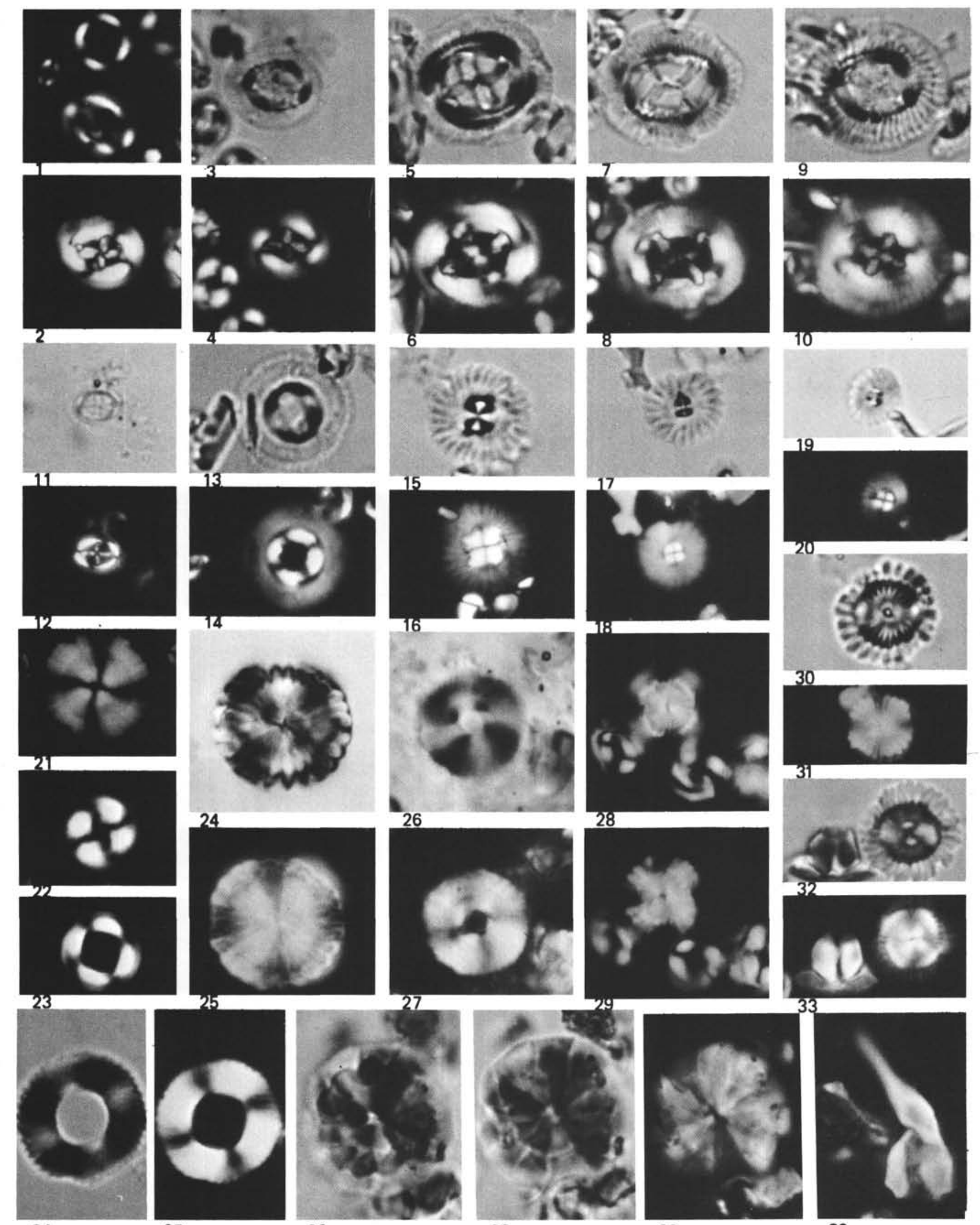

35

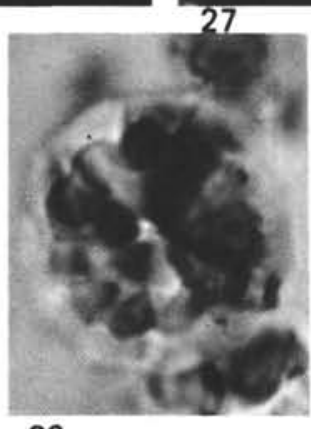

36
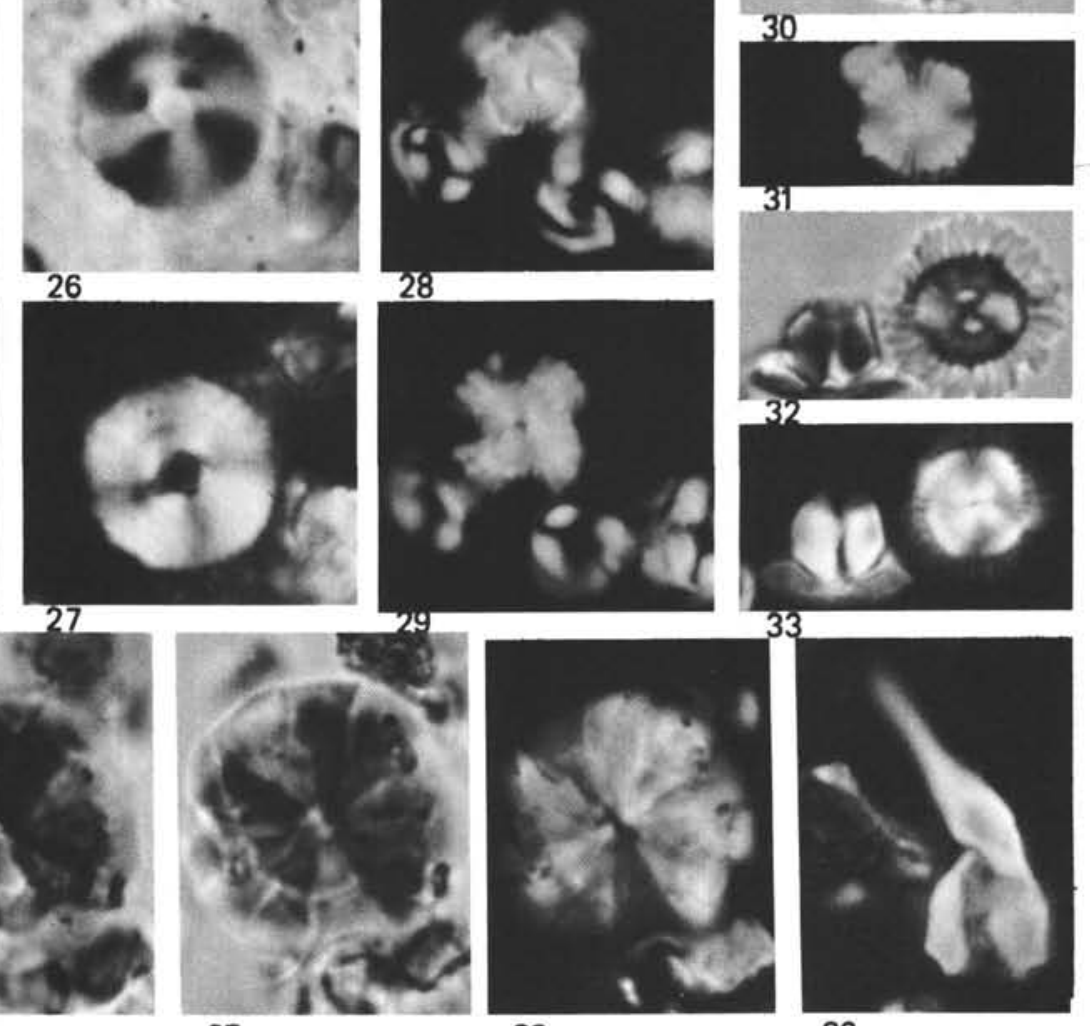

37

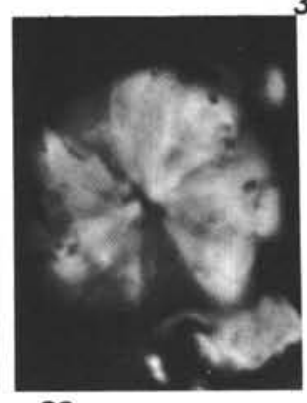

38

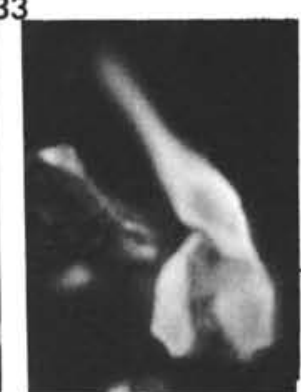

39 